\title{
ALTERNATIVE METHODS AND FORUMS TO OPTIMIZE PUBLIC PARTICIPATION IN THE PLANNING PROCESS
}

\author{
A Thesis \\ presented to \\ the Faculty of California Polytechnic State University, \\ San Luis Obispo
}

\begin{abstract}
In Partial Fulfillment
of the Requirements for the Degree

Master of City and Regional Planning
\end{abstract}

by

Joseph James David

April 2010 

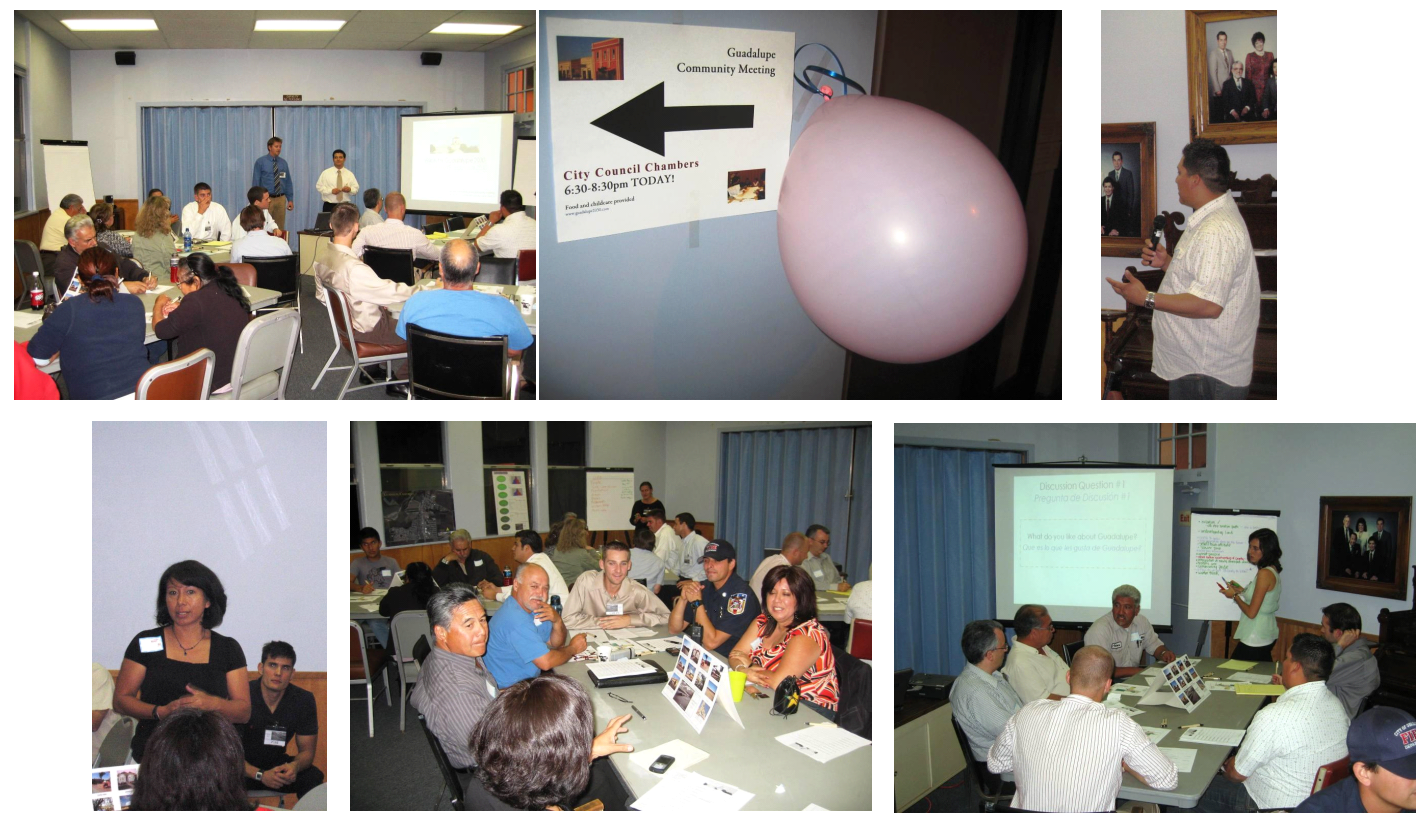

Guadalupe Community Workshop

(C) 2010

Joseph James David

ALL RIGHTS RESERVED 
COMMITTEE MEMBERSHIP

TITLE: ALTERNATIVE METHODS AND FORUMS TO OPTIMIZE PUBLIC PARTICIPATION IN THE PLANNING PROCESS

AUTHOR: Joseph James David

DATE SUBMITTED: $\quad$ April 2010

COMMITTEE CHAIR: Umut Toker, Ph.D.

Cal Poly City and Regional Planning

COMMITTEE MEMBER: William Siembieda, Ph.D.

Cal Poly City and Regional Planning

COMMITTEE MEMBER: John Mandeville, Director

City of San Luis Obispo Community Development 


\section{ABSTRACT}

\section{ALTERNATIVE METHODS AND FORUMS TO OPTIMIZE PUBLIC PARTICIPATION IN THE PLANNING PROCESS}

Joseph James David

"Public participation" takes on various forms in the realm of local government planning. Many planners stand behind the ideal of involving community, but participation in practice often fails to achieve this objective. The primary vehicle for local government participation is the public hearing, which is a formalized process that often elicits one-way communication from planner to public. The nature of a hearing is to inform the public about development applications or policy changes, expose governing body decisions to the public, and elicit reactions from interested members of the public. Significant effort is taken daily by local planning departments to promote this transparent form of decisionmaking. The public can stay informed by reading legal ads in the newspaper, checking municipal websites, paying attention to public notice signs, attending hearings or simply receiving a hearing notice in their mailbox. However, staying informed and being involved are two completely different concepts. True involvement is two-way communication between public and planner. This study reports that the public hearing does not provide this necessary involvement. Alternative methods, such as workshops, are explored that break the formal mold of local government participation. Findings indicate that participation is more genuine in a loosely structured setting where face-to-face communication can occur between public and planner and among members of the public themselves. However, findings also suggest that genuine participation is not always appropriate given the intent of a public meeting. Many hearings are held at the end of the planning process for development applications requiring quasi-judicial decisions based on standards. The key is getting public input on earlier legislative decisions about policies that define the standards themselves. This study concludes with a toolkit of techniques practitioners can use to enhance public participation in planning, and observations about appropriate stages to implement those techniques in the planning process. 


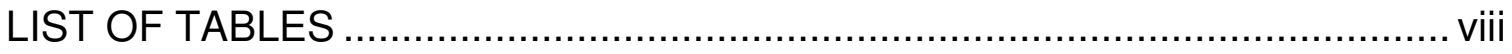

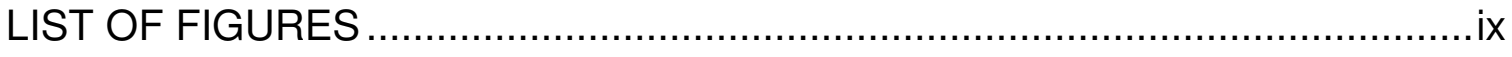

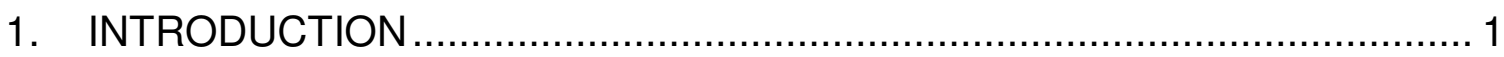

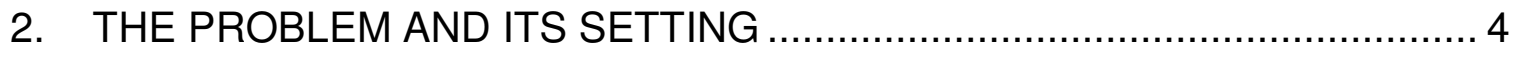

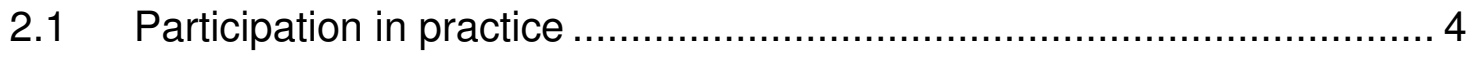

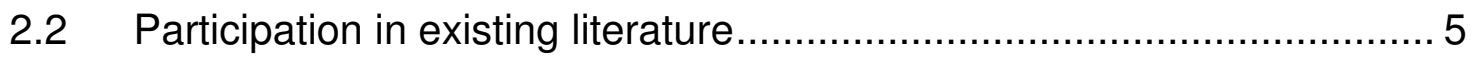

3. REVIEW OF EXISTING LITERATURE ............................................. 10

3.1 Genuine vs. pseudo participation ................................................. 10

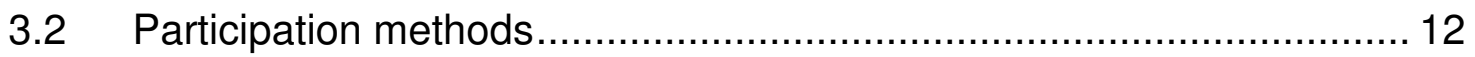

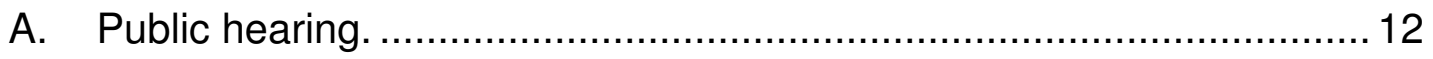

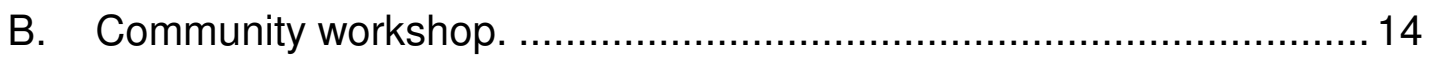

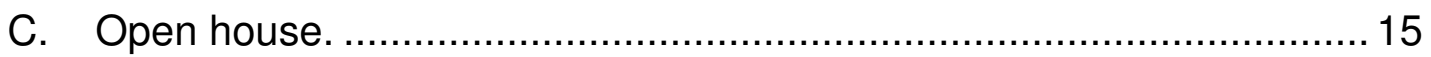

D. Stakeholder meetings/focus group.................................................... 16

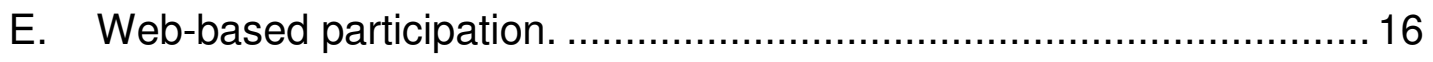

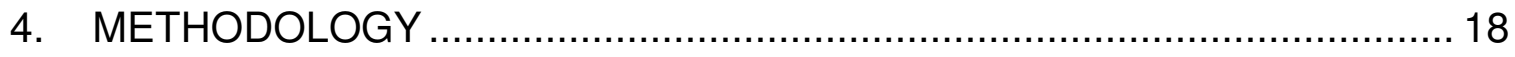

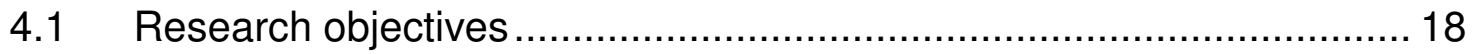

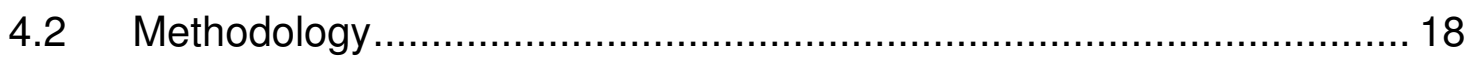

4.3 Methods and instrumentation ..................................................... 18

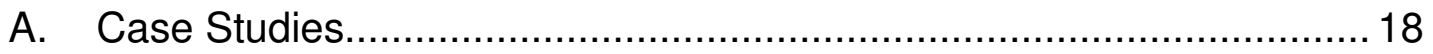

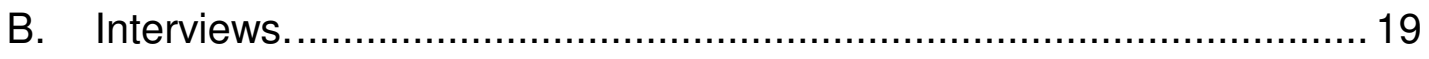

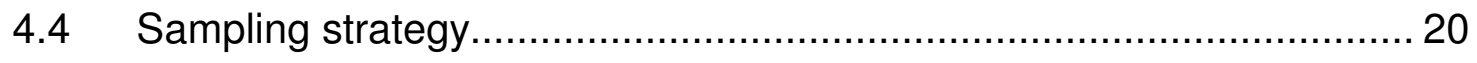




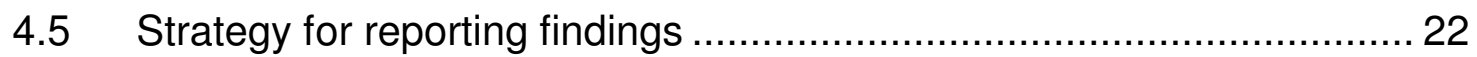

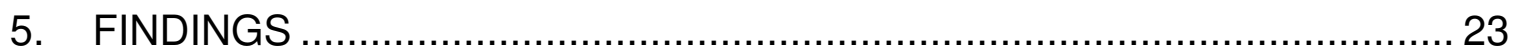

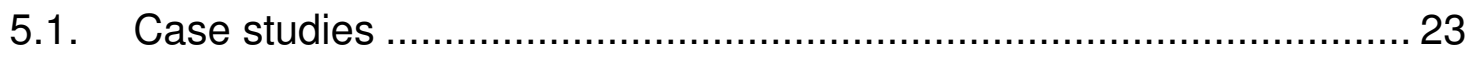

06/07/07 - Study Session: Santa Maria Planning Commission.................... 23

10/17/07 - SLO Planning Commission Special Workshop......................... 26

11/28/07 - San Luis Obispo Planning Commission Regular Meeting. ........ 30

04/07/08 - SLO Architectural Review Commission Regular Meeting.......... 33

10/23/08 - Vision for Guadalupe 2030: Community Meeting One............... 37

11/20/08 - Vision for Guadalupe 2030: Community Meeting Two............... 41

02/05/09 - Vision for Guadalupe 2030: Community Meeting Three............ 45

02/26/09 - Vision for Guadalupe 2030: Community Meeting Four.............. 47

03/12/09 - Vision for Guadalupe 2030: Community Meeting Five............... 50

06/15/09 - San Luis Obispo County Budget Hearings. ............................... 54

06/16/09 - Atascadero City Council \& Planning Commission. ..................... 56

08/18/09 - SLO Preservation and Design Review Workshop. ....................61

09/10/09 - City of San Luis Obispo Housing Element Workshop............... 64

11/19/09 - SLO Climate Action Plan Community Workshop....................... 67

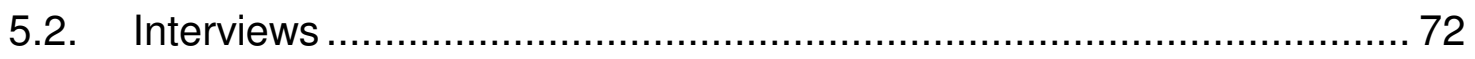

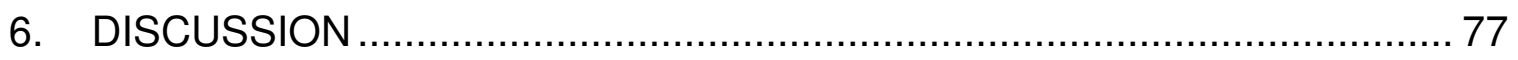

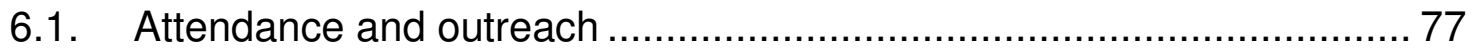

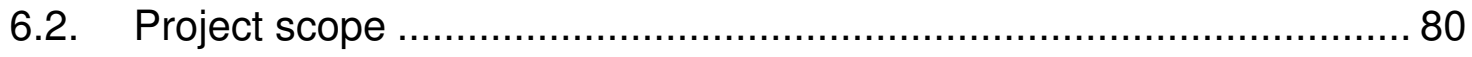

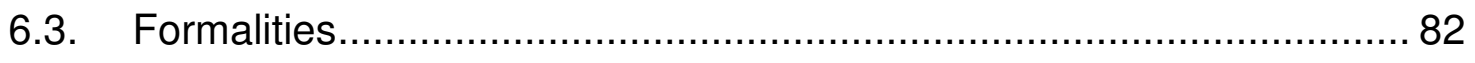

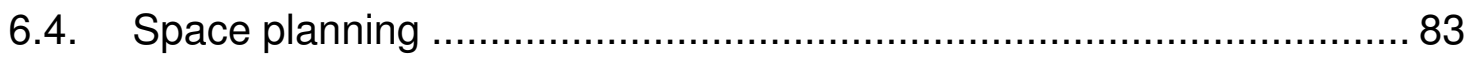

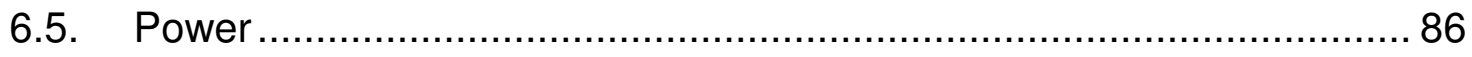




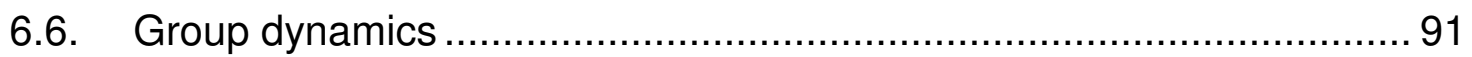

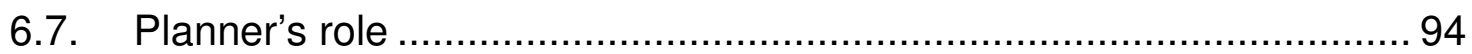

6.8. Technology

7. CONCLUSIONS AND FUTURE IMPLICATIONS ................................... 100

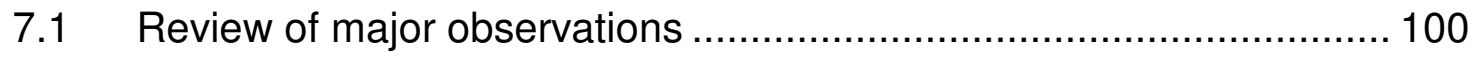

7.2 Measuring effectiveness in engaging the public .............................. 106

7.3 A participation toolkit for planning practitioners ............................... 107

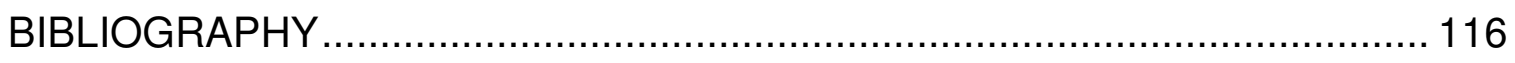

APPENDIX A: Case Study Field Notes …................................................... 119

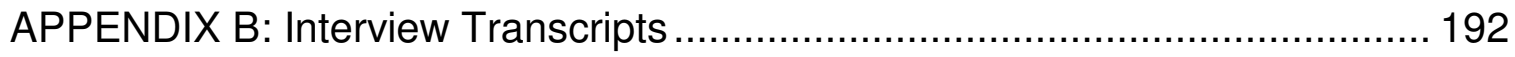




\section{LIST OF TABLES}

Table

1. The shift from strictly instrumental to practical-communicative action........ 8

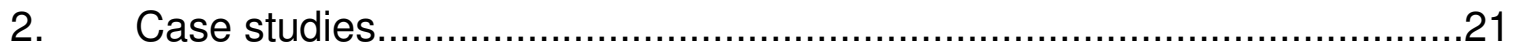

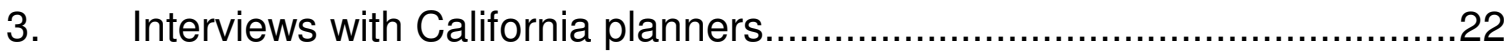

4. Comparative summary of case study observations...............................78

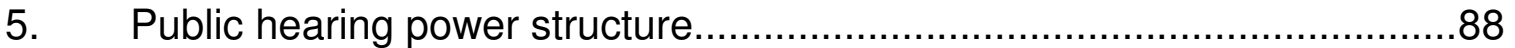

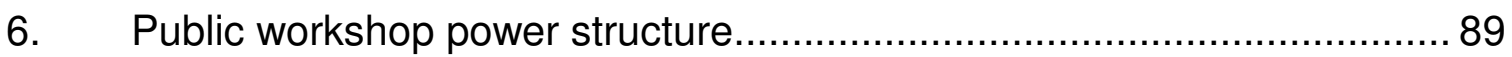

7. Modified interpretation of Forester's table.............................................96

8. Distinctions between participation methods........................................102

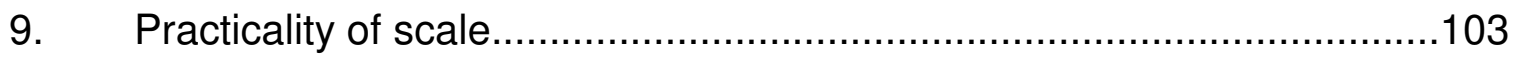

10. Determining the type of input needed based on the desired outcome....108 


\section{LIST OF FIGURES}

Figure

Page

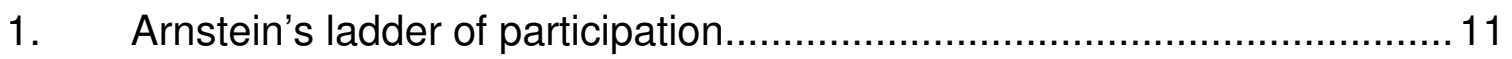

2. Role of participation in community design...................................11

3. Picket sign in opposition to project........................................... 35

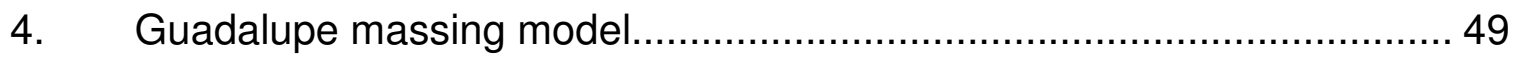

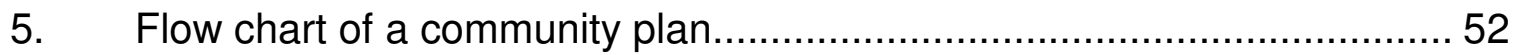

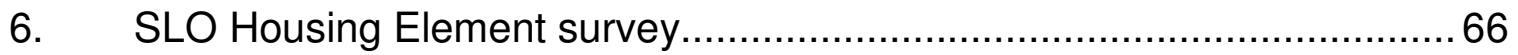

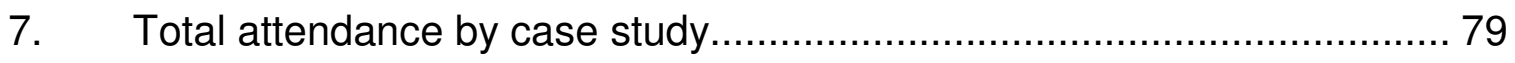

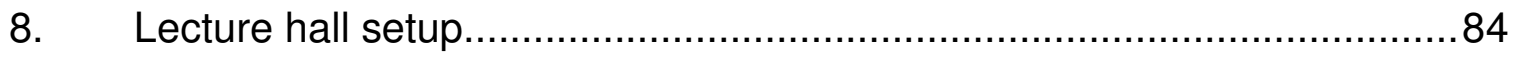

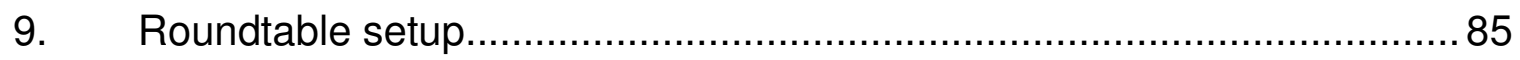

10. Comparison of average speaking time by participant........................ 91

11. Best and worst cases of speaker duration.................................. 92

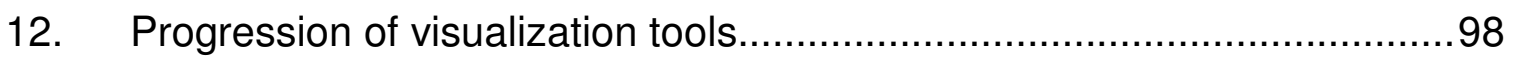

13. Measuring effectiveness in engaging the public............................107

14. A mixed-method participation approach...................................113 


\section{INTRODUCTION}

Public participation should be a democratic process that informs decision makers about the objectives and concerns of the affected community (Brooks, 2002). Planners typically employ the existing standard - the public hearing - to achieve this objective.

The roots of public hearings stem from a desire for government "transparency". Residents must be able to "see through" the workings of government to know exactly what goes on when public officials transact public business. Government that is not transparent is more prone to corruption and undue influence because there is no public oversight of decision making (Nadler, 2006). In California, the Ralph M. Brown Act (CA Gov. Code, § 54950) provides government transparency by requiring open meetings for local government bodies, including city councils, boards of supervisors, and district boards. The Brown Act requires adequate public notice prior to any meeting and that every agenda for a regular meeting provide an opportunity for members of the public to give testimony. As the courts have stated, the purpose of the Brown Act is to facilitate public participation in local government decisions and to curb misuse of the democratic process by secret legislation by public bodies (Cohan v. City of Thousand Oaks (1994) 30 Cal.App.4th 547, 555).

A significant point of concern is whether "public testimony" is adequate public participation. "Participation" implies a level of proportionate decision making power. Hearing attendees from the general public are given a set time limit to express their views about a particular agenda item. This window of opportunity is 
usually at the end of the meeting, and largely at the end of the planning process when decisions have already been made.

This study investigates what levels of public participation occur in local government planning. The premise is that public participation is an essential component of modern planning, because educating the community and implementing public preferences in certain planning actions leads to successful policies, plans and projects. The objective is to develop a toolkit of techniques that planners and government officials can use to enhance public participation throughout all stages of the planning process.

Initially, a discussion of public participation in practice is carried out, followed by a review of participation theory as it pertains to planning decisions. Existing literature categorizes public involvement in planning into two general classifications: genuine participation versus pseudo participation. Different participation methods are identified that fit into these two categories.

The method for analysis is observation of multiple case studies, which inform findings about the practice of public participation in local government planning. Two primary methods are evaluated at different ends of the participation spectrum: the public hearing and public workshop. This cross-comparison approach helps establish what parameters of participation events elicit varying behaviors from the general public, and offers analysis of public behavior in meetings to determine when and where genuine participation can and should occur. Interviews with current practitioners are conducted that validate observations in the field and offer additional solutions for gathering public input. 
This study concludes with a toolkit of techniques practitioners can use to enhance public participation in planning, and observations about appropriate stages to implement those techniques in the planning process. 


\section{THE PROBLEM AND ITS SETTING}

\subsection{Participation in practice}

The goal of public participation is to educate and involve the affected community in every stage of planning decisions. Studies have shown that involving the public early and often in the planning process will increase the likelihood that the resulting plans, programs and public policy will be successfully implemented (So, et al., 2000). If local residents are directly involved in the planning process they will be able to identify with the reasons behind planning decisions and take ownership of implementing the objectives of the plan. There is no better watchdog than the eyes and ears of an involved constituency. Planning should be a dynamic and open process that welcomes community input at all levels of decision-making. The State of California recognizes this in planning and zoning legislation:

\section{Public participation}

The Legislature recognizes the importance of public participation at every level of the planning process. It is therefore the policy of the state and the intent of the Legislature that each state, regional, and local agency concerned in the planning process involve the public through public hearings, informative meetings, publicity and other means available to them, and that at such hearings and other public forums, the public be afforded the opportunity to respond to clearly defined alternative objectives, policies, and actions (Planning and Zoning Law, State of California).

The Legislature leaves the public involvement process open to public hearings, informative meetings, and other public forums. Public hearings emerge from the list as the predominant vehicle for involving the public, especially because certain development actions legally require public hearings (Planning and Zoning Law, CA). In 2007, approximately 80 percent of the City of San Luis Obispo Planning Department's public participation efforts were public hearings (City of San Luis 
Obispo, 2007). This heavy reliance on public hearings is not uncommon for most planning departments. Local governments encourage private sector planners and developers to conduct informational meetings and outreach to those affected by their development projects, but workshops are usually limited to City-sponsored projects that occur sporadically throughout the year.

Many planners support the idea of public involvement in planning, but in practice there is a considerable amount of cynicism among planners about the benefits of citizen participation (Brooks, 2002). As a result, community participation in planning elicits mixed reviews from decision-makers. City managers and council members in many cities resist public involvement because of increased costs, time and effort (Fulton, 1999). Public workshops have a fiscal impact on declining local government resources, and managers see no problem with decision-making elite. Planners practice public participation because it aligns with their value systems, but they rarely expect it to achieve any measurable progress (Brooks, 2002).

\subsection{Participation in existing literature}

Civil movements of the 1960s propelled the whole nation towards active participation. Until that time, public input played a minority role in shaping the design of cities. Paul Davidoff (1965) pioneered new directions in advocacy planning, an attempt to decentralize the decision-making process and make it more representative of the entire community. Davidoff (1965) argued that planning is political, whereby different interest groups compete to influence policy based on their own social agenda. Competing interest groups have varying 
degrees of power and representation, which creates inequalities among stakeholders in the planning process. Davidoff (1965) suggested that it is the role of planners to equalize the democratic playing field by representing the objectives of disadvantaged groups in planning practice. This will enable underrepresented residents to provide valuable input on the plans created for their community.

Michael Brooks (2002) stated that advocacy planning implies that "major decisions should be placed in the hands of the citizenry itself". Emphasis is shifted from the technical expert to the diversity of competing interest groups within the community. However, the rational model remains the predominant mode for making planning decisions. Rationality is premised on finding the "correct answer", and assumes that people will choose to maximize utility when faced with competing alternatives (Banfield, 1959). Advocacy planning simply increases the number of alternatives considered and expands the umbrella of individuals who will benefit from the rational planning process (Brooks, 2002).

Current participation advocates prescribe to communicative action theory, which evolved from Davidoff's advocacy planning. Communicative action theorists concern themselves more with the process of arriving at planning decisions than the actual rationality of the decision itself. Postmodern planners that practice communicative action feel that planning should be highly interactive and include as many stakeholders as possible. The ultimate goal of communicative planning is to create collective meaning among differing interest groups, with the best-case scenario resulting in consensus (Innes, 1998). 
Implicit in the communicative action approach is the idea that there are many types of embedded information that govern people's behaviors (Innes, 1998). Planning is not simply "talk" or "effective communication skills"; all of the planner's actions - behavioral cues, silence, acknowledgements, body language and verbal communication - shape the expectations and desires of participating stakeholders (Forester, 1993). It can be argued that this is true for all professions that practice in the public eye. Planners should be well aware that every public action shapes resident understanding, which has potentially serious affects.

Within the communicative action approach of consensus building, technical analysis from the expert planner is not the sole source of information that influences decisions; participant experience, personal stories, images and intuition are given equal weight (Innes, 1998). Technical information is not taken as fact, it is "discussed and validated within the consensus building process" (Innes, 1998).

Communicative action theory is a major departure from the "behind closed doors" method of the traditional rational paradigm. Communicative action theorists believe that planners should not consider alternatives privately and present the "correct answer" to the public; instead they should present all the information to the community - being well aware of the adverse reactions that can stem from communication - and foster creative collaboration among stakeholders in order to arrive at a plausible course of action defined by the community. Table 1 is adapted from Forester's (1993) explanation of the major distinctions between the rational paradigm and communicative action theory. For 
Table 1

The Shift from Strictly Instrumental to Practical-Communicative Action

\begin{tabular}{llll}
\hline INSTRUMENTAL & TO & PRACTICAL-COMMUNICATIVE & \\
\hline $\begin{array}{l}\text { seeking detachment to further } \\
\text { objectivity }\end{array}$ & to & $\begin{array}{l}\text { seeking criticism to check bias and } \\
\text { misrepresentation }\end{array}$ \\
\hline $\begin{array}{l}\text { treating participation as a source of } \\
\text { obstruction }\end{array}$ & to & $\begin{array}{l}\text { treating participation as an opportunity to } \\
\text { improve analysis }\end{array}$ \\
\hline $\begin{array}{l}\text { informing decisions } \\
\text { reinforcing political dependency of } \\
\text { affected persons }\end{array}$ & to & $\begin{array}{l}\text { Fostering meaningful political participation } \\
\text { and autonomy }\end{array}$ \\
\hline passing on "solutions" & to & $\begin{array}{l}\text { fostering policy and design criticism, } \\
\text { argument, and political discourse }\end{array}$ \\
\hline
\end{tabular}

Note. Reprinted from "Planning Practice as Communicative Action," by Forester, 1993.

the sake of brevity, only those sections of Forester's table that are directly related to public participation are included. It is evident that the role of the planner shifts from expert decision-maker to cautious mediator within the context of communicative action theory (Forester, 1993). Mediated negotiation emerges as a viable skill that planners can use to facilitate community-based input in the planning process (Brooks, 2002). Communication becomes a two-way flow between mediator and public, instead of the one-way communication that dominates traditional planning practice.

The downside to communicative action theory is that building consensus in a politically charged community takes considerable time. Updating policies or designing a public plaza could turn into a seven-year long planning effort. It is difficult to appease competing interest groups on opposite sides of a political "hot potato". Furthermore, significant amounts of local government planning actions 
are determinations of consistency with adopted development standards. If consensus is necessary for making this type of determination the standard is inadequate. Consensus among stakeholders is an ideal to strive for when making policy decisions that affect the entire community, but does not serve a practical purpose for quasi-judicial actions taken by elected officials. 


\section{REVIEW OF EXISTING LITERATURE}

\subsection{Genuine vs. pseudo participation}

Sanoff (2000) argued that public hearings are nonparticpatory. Deschler and Sock (1985) divided participation into two distinct types: genuine participation and pseudo participation. Pseudo participation is defined by two categories: domestication, which involves informing, therapy and manipulation, and assistencialism, which is placation and consultation (Sanoff, 2000). Genuine participation on the other hand is defined as cooperation - partnership and delegation of power - and citizen control which means empowerment (Sanoff, 2000). The public hearing and other participation processes that present information about what is being planned for the community are pseudo participation. Genuine participation occurs when the community is involved in the decision-making process (Sanoff, 2000).

These concepts are further illustrated in Figure 1, which is Arnstein's (1969) ladder of differing degrees of participation and the corresponding levels of communication between the agency and the community. The labels on the left are added for clarification of which types of participation are considered genuine versus pseudo participation.

Ascending Arnstein's ladder towards genuine participation reveals that communication moves from one-way communication (agency to participants) to two-way communication. The top of the ladder is complete citizen control, which could have serious repercussions. The technical complexities of development projects require professional assistance in the form of sound design and 


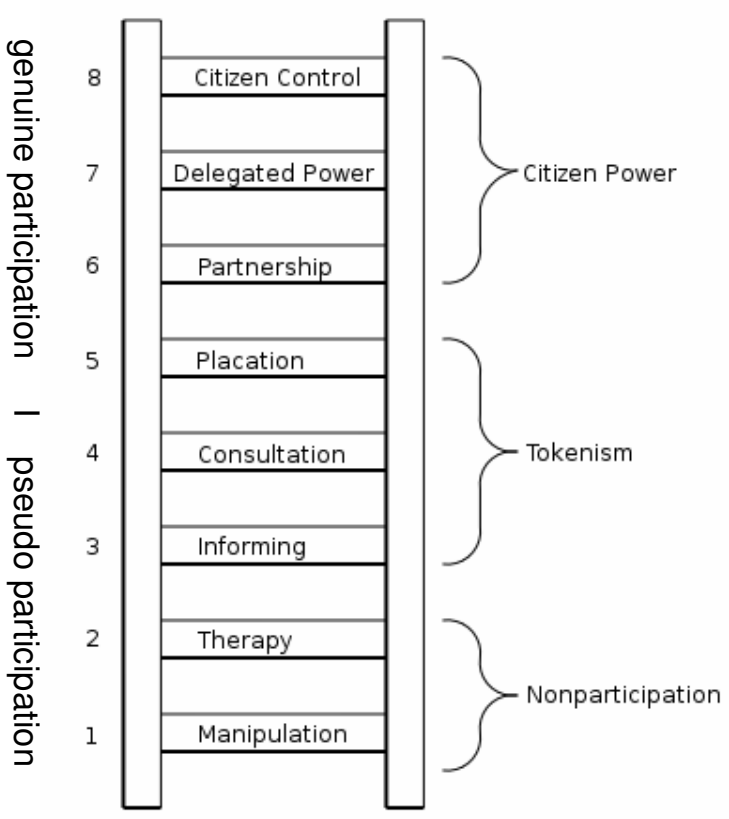

Figure 1. Arnstein's ladder of participation.

Note. Adapted from "A ladder of citizen participation" by Arnstein, 1969.

implementation of good planning principles. A more pragmatic approach is to delegate power or to have planners serve as advocates for underrepresented segments of the community. Figure 2 offers an alternate interpretation of the levels of communication between planners and the affected constituency.

Continuum 1 delineates the role of the planner while Continuum 2 exemplifies the degree of involvement by the community. Representation, questionnaires and regionalism as a basis for making decisions is still largely one-way

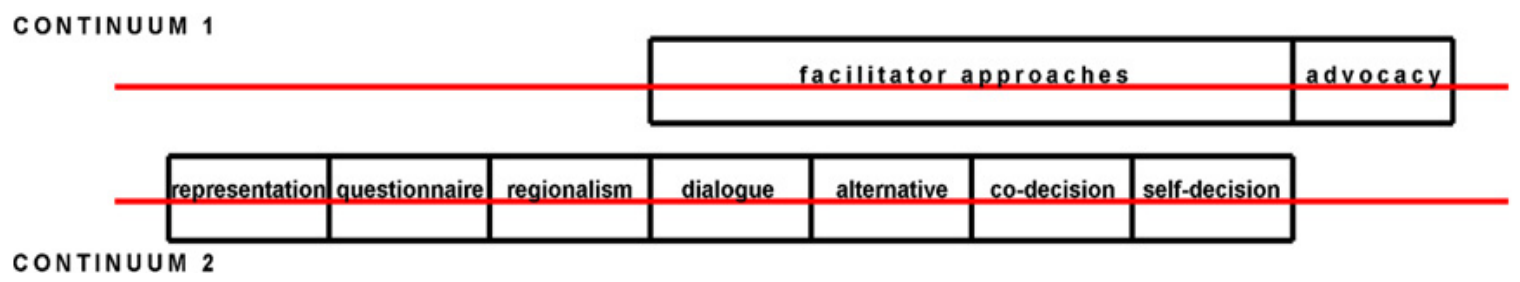

Figure 2. Role of participation in community design.

Note. Reprinted from "Recent trends in community design" by Z. Toker, 2007. 
communication. The planner acts as an information gatherer. Community dialogue, alternatives, co-decision and self-decision transform the planner into facilitator instead of decision-maker. Finally, advocacy requires two-way communication up front, but elicits little public input at the decision-making level because the planner is representing community interests entirely. The role of the planner transitions from analyst to enabler, requiring a blend of technical expert and facilitator.

\subsection{Participation methods}

Traditional public participation methods such as public hearings that rely on government experts too often become battles among angry citizens, practitioners and elected officials (Booher and Innes, 2005). New perspectives suggest that "scientifically" developed knowledge by experts is not the only, or even the best, form of knowledge for public decisions (Booher and Innes, 2010). Many governmental agencies today see value in collaborative dialogue with the public. Participation techniques to achieve these purposes range from public agencies pulling together stakeholders for joint discussion to fully fledged consensus building efforts (Booher and Innes, 2010). The following sections review participation methods that are the most prevalent in local government planning.

A. Public hearing. Hearings and public scoping meetings are the traditional format for public participation. Most municipalities in California expose the public to quasi-judicial decisions via a public hearing. Upcoming hearings are usually announced in the local newspaper. Staff reports are available beforehand so the public can educate themselves and speak to the issues or alternatives at 
the hearing. Public hearings are run by a Council, Board or planning staff and are largely informative. Staff presentations are given describing the proposed project, the Council conducts a question and answer period with staff and applicants, followed by an opportunity for public comment. Community members wishing to speak are given approximately three minutes to state their case and Council takes each public comment under advisement. Participants typically prepare their comments in advance (Personal observation, 2008).

The public hearing adheres to the rational planning paradigm because it is usually a quasi-judicial process. Expert knowledge is dominant when it comes to interpreting plans or policies, and lay knowledge is important only as it reveals general public preferences (Booher and Innes, 2010). Most public input is reaction from Not-In-My-Backyard (NIMBY) advocates and other individuals that are already invested in local politics. The structured formalized setting of a public hearing is not designed for representative public engagement.

Study sessions are a variation of public hearings where no final action is taken. They are less formal than a public hearing and more formal than a workshop. The focus is usually on legislative projects or planmaking. These open meetings are interactive questions and answer sessions between the public and officials. Residents are allowed to speak up repeatedly with no specified time limits for input. The input from study sessions can be used to create goals, objectives, policies and programs in community plans. Study sessions engage the community early in the process, which can mitigate some NIMBY reaction at implementation. 
B. Community workshop. Workshops are an interactive forum that enables members of the public to directly influence the planning process. A presentation by planners is followed by group activities that promote discussion and interaction among community members. Community members are usually broken into small groups that are facilitated by staff. The product of group activities is then presented to all workshop attendants and planners use that input to craft goals, objectives, policies, programs and plans. Pioneered by Henry Sanoff, community workshops typically involve games or methods that focus on hands-on design activities like sketching development maps and determining where land uses shall be located (Sanoff, 2000).

Design charrettes are a form of community workshops that are also interactive. The idea behind a charrette is to graphically portray development concepts to participants in poster format and solicit public feedback. Sometimes the design charrette poster will be manipulated by the urban designer or planner as the public provides comment, allowing for additional comment on evolving design concepts. Design charrettes have become popularized in the planning ideals of New Urbanism (Talen, 1999).

Sanoff (2000) contends that the workshop is the best forum for public participation in community design because it enables every participant to have a voice. Structured workshops with small group activities give community members a chance to get their hands on a particular development problem in a less imposing environment than the public hearing. Small breakout tables elicit debate and eventual consensus-building among four to eight stakeholders. Those views 
are than shared with the larger group and the visioning process begins to take hold. Information flow becomes a two way dialogue between residents and planners.

Government planners often use workshops to determine public preferences about specific questions that stem from a larger predetermined feasible framework. Workshop activity results are evaluated with respect to sound design and planning principles, and translated to decision-makers through policy alternatives based on workshop outcomes.

Many current practitioners of public workshops contend that technologies such as interactive "clicker" voting systems, participatory games, and visioning exercises help draw a representative sample of the targeted community, which strengthens overall public participation efforts (Al-Kodmany, 2002; Sanoff, 2000).

C. Open house. The open house or town hall meeting is a hybrid of workshop and hearing often utilized in the middle of the planning process. Drafts of a conceptual plan, three dimensional models or other proposed projects are displayed in a central location that is accessible to all community members. The open house hours are advertised in the local paper and other forms of media, and the general public is invited to view and comment on the proposed designs during that time period. The major distinction is that there are usually multiple stations set up to receive the public and ample time allotted for collaboration on design improvements between public and planner (Personal communication with D. Javid, 2007). 
D. Stakeholder meetings/focus group. Stakeholder meetings are preliminary discussions among parties directly involved in the planning process. They usually involve planners, public officials, consultants, developers and affected community members. Focus group meetings are similar to stakeholder meetings because key individuals are selected for a presentation about proposed development. Both forums are usually set up in the early planning stages and are not open to the general public (Sanoff, 2000). Council-appointed citizen advisory committees are a special focus group of representatives from different interests selected to provide ongoing advice and recommendations to a government body (So, et al., 2000).

E. Web-based participation. Web-based forums focus on creating a twoway channel for communication between planner and public via the Internet. Maps, design proposals and surveys are posted on the Internet so community members can view and respond at their leisure. As access to the Internet is becoming more readily available many planners are switching to web-based participation to examine development preferences among the affected constituency (Al-Kodmany, 2005). Technology can significantly enhance existing public participation standards. Al-Kodmany (2002) suggested that computerized tools, such as web-based mapping and interactive GIS scenarios, enhance reactive public participation. Kobza (2005) argued that a web-based interface for public participation strengthens outreach efforts and improves the quality of public feedback. 
The level and type of public input differs in each of the aforementioned participation methods. Moving from informal web forums to formal hearings, direct public participation decreases as the setting becomes more formal. Public participation in hearings and study sessions is regulated by defined rules of order that restrict public involvement to listening in the audience and limited testimony. Conversely, workshops, open houses, stakeholder meetings and web forums have loosely defined settings that encourage direct public input through open dialogue. There is an inverse relationship between formal settings and the degree of direct public participation. The key for practitioners is determining which setting is appropriate given the project and its corresponding decisionmaking process. 


\section{METHODOLOGY}

\subsection{Research objectives}

The objective is to determine which public participation techniques are the most effective relative to the desired target. Comparison of different types of participation events indicates what techniques enhance public participation in planning, and when it is appropriate to use them depending on the practitioner's desired outcome.

\subsection{Methodology}

Research was conducted on participation techniques and outcomes through a two-step process: case studies of participation events and interviews of public sector professionals. The first step was personal observation of different cases. The case study is preferred in examining contemporary events, especially when the investigator has little or no control over the behavioral events being studied (Yin, 2003). Interviews with professionals were the second step. This established an understanding of how practitioners view the efficacy of community participation in practice, and helped validate observations made in the field.

\subsection{Methods and instrumentation}

A. Case Studies. The primary research instrument for case studies was firsthand observation and categorized note-taking to gather data that informs comparative analysis across all cases. Observations about general data including methodology, location, date, time, duration, attendance, weather, and number of presenters were made for each participation event. Additional data was collected about meeting characteristics including: meeting purpose, level of 
dialogue, speaker duration, visualization tools, structure, setting, stage in the planning process, method of interaction, and public notification method. Completed research instruments for each case study are included in Appendix A. The independent variable was the public participation method. Research and observations inform distinctions between different methods. The dependent variable was effectiveness of public participation. Qualitative criteria measuring how effective meetings were at engaging the public were: total attendance, breadth of attendance, opportunities to participate, level of active participation, resolution of apparent issues, public behavior/body language, clarity of presentation, communication to public, and implementation of community ideas. Each case study received a rating for each qualitative criterion based on a 5point interval scale (1 - Poor 2 - Fair 3 - Good 4 - Very Good 5 - Excellent). Ratings are subjective based upon what is observed.

Geographic location was a controlled variable in case studies to strengthen the comparative analysis of participation techniques. The major confounding variable was the purpose of the public participation event. Certain events are strictly informational and others are designed to be interactive. In order to minimize the adverse affects of this confounding variable, case studies that have a similar planning-related purpose or focus were selected. The author's bias due to present employment as Assistant Planner for the City of San Luis Obispo was diminished by relying on objective observation and ethnographic analysis.

B. Interviews. The secondary research instrument was interviews with planning professionals via telephone and in person. Appendix B contains 
interview transcripts that provide anecdotal accounts of the public participation process from the viewpoint of selected interviewees.

Scope of a project was evaluated in interviews to determine what types of participation are appropriate for different desired outcomes. A workshop may be more effective for legislative decisions that have a broader impact, such as a General Plan, while a public hearing may be more suitable for quasi-judicial actions by a governing body.

The practicality of scale was also evaluated in interviews to determine which participation techniques are more effective for large groups. Since most case studies were in cities in San Luis Obispo County with relatively smaller populations, the majority of interviewees were selected from other larger California cities to evaluate how size of meetings affects participation in practice.

\subsection{Sampling strategy}

Multiple case studies were conducted of public meetings in San Luis Obispo and Santa Barbara Counties from June 2007 to November 2009. The sampling strategy was stratified purposeful sampling of different types of public participation events. Table 2 lists each case study, the location and type of participation event in chronological order.

Telephone and in-person interviews were conducted with California planners in March 2010. Interviewees were selected based on job title, geographic location and experience. Respondents are planning managers or directors in the cities listed in Table 3. Cities were selected with similar median household income and populations ranging from 45,000 to 4.1 million people. 
Table 2

Case studies

\begin{tabular}{|c|c|c|c|c|c|}
\hline Key & Event & Location & Method & Setting & Date/Time \\
\hline $\mathrm{H} 1$ & $\begin{array}{l}\text { Planning Commission } \\
\text { Study Session }\end{array}$ & $\begin{array}{l}\text { City of Santa } \\
\text { Maria }\end{array}$ & Hearing & $\begin{array}{l}\text { City Council } \\
\text { Building }\end{array}$ & $\begin{array}{l}06 / 07 / 2007 \\
10 \mathrm{am}\end{array}$ \\
\hline W1 & $\begin{array}{l}\text { Planning Commission } \\
\text { Special Workshop }\end{array}$ & $\begin{array}{l}\text { City of San Luis } \\
\text { Obispo }\end{array}$ & Workshop & $\begin{array}{l}\text { City/County } \\
\text { Library }\end{array}$ & $\begin{array}{l}10 / 17 / 2007 \\
5: 30 \mathrm{pm}\end{array}$ \\
\hline $\mathrm{H} 2$ & $\begin{array}{l}\text { Planning Commission } \\
\text { Regular Meeting }\end{array}$ & $\begin{array}{l}\text { City of San Luis } \\
\text { Obispo }\end{array}$ & Hearing & $\begin{array}{l}\text { Council } \\
\text { Chambers }\end{array}$ & $\begin{array}{l}11 / 28 / 2007 \\
7 \mathrm{pm}\end{array}$ \\
\hline H3 & $\begin{array}{l}\text { Architectural Review } \\
\text { Commission Meeting }\end{array}$ & $\begin{array}{l}\text { City of San Luis } \\
\text { Obispo }\end{array}$ & Hearing & $\begin{array}{l}\text { Council } \\
\text { Chambers }\end{array}$ & $\begin{array}{l}04 / 07 / 2008 \\
5 \mathrm{pm}\end{array}$ \\
\hline W2 & Vision for Guadalupe 2030 & $\begin{array}{l}\text { City of } \\
\text { Guadalupe }\end{array}$ & Workshop & $\begin{array}{l}\text { Council } \\
\text { Meeting } \\
\text { Room }\end{array}$ & $\begin{array}{l}10 / 23 / 08 \\
6: 30 \mathrm{pm}\end{array}$ \\
\hline W3 & Vision for Guadalupe 2030 & $\begin{array}{l}\text { City of } \\
\text { Guadalupe }\end{array}$ & Workshop & $\begin{array}{l}\text { Council } \\
\text { Meeting } \\
\text { Room }\end{array}$ & $\begin{array}{l}11 / 20 / 08 \\
6: 30 \mathrm{pm}\end{array}$ \\
\hline W4 & Vision for Guadalupe 2030 & $\begin{array}{l}\text { City of } \\
\text { Guadalupe }\end{array}$ & Workshop & $\begin{array}{l}\text { Senior } \\
\text { Center }\end{array}$ & $\begin{array}{l}02 / 05 / 09 \\
6: 30 \mathrm{pm}\end{array}$ \\
\hline W5 & Vision for Guadalupe 2030 & $\begin{array}{l}\text { City of } \\
\text { Guadalupe }\end{array}$ & Workshop & $\begin{array}{l}\text { Senior } \\
\text { Center }\end{array}$ & $\begin{array}{l}02 / 26 / 09 \\
6: 30 \mathrm{pm}\end{array}$ \\
\hline $\mathrm{H} 4$ & Vision for Guadalupe 2030 & $\begin{array}{l}\text { City of } \\
\text { Guadalupe }\end{array}$ & Hearing & $\begin{array}{l}\text { Senior } \\
\text { Center }\end{array}$ & $\begin{array}{l}03 / 12 / 09 \\
6: 30 \mathrm{pm}\end{array}$ \\
\hline H5 & Budget Hearings & $\begin{array}{l}\text { San Luis } \\
\text { Obispo County }\end{array}$ & Hearing & $\begin{array}{l}\text { County } \\
\text { Government } \\
\text { Offices }\end{array}$ & $\begin{array}{l}06 / 15 / 09 \\
9 \mathrm{am}\end{array}$ \\
\hline $\mathrm{H} 6$ & $\begin{array}{l}\text { Special Joint Meeting: } \\
\text { Council and Planning } \\
\text { Commission }\end{array}$ & $\begin{array}{l}\text { City of } \\
\text { Atascadero }\end{array}$ & Hearing & $\begin{array}{l}\text { City Hall, } \\
\text { Council } \\
\text { Chambers } \\
\end{array}$ & $\begin{array}{l}06 / 16 / 09 \\
7 \mathrm{pm}\end{array}$ \\
\hline W6 & $\begin{array}{l}\text { Preservation/Design } \\
\text { Review Workshop }\end{array}$ & $\begin{array}{l}\text { City of San Luis } \\
\text { Obispo }\end{array}$ & Workshop & $\begin{array}{l}\text { City/County } \\
\text { Library }\end{array}$ & $\begin{array}{l}08 / 17 / 2009 \\
08 / 18 / 2009\end{array}$ \\
\hline W7 & $\begin{array}{l}\text { Housing Element } \\
\text { Workshop }\end{array}$ & $\begin{array}{l}\text { City of San Luis } \\
\text { Obispo }\end{array}$ & Workshop & $\begin{array}{l}\text { Community } \\
\text { Center }\end{array}$ & $\begin{array}{l}09 / 10 / 2009 \\
6 \mathrm{pm}\end{array}$ \\
\hline W8 & $\begin{array}{l}\text { Climate Action Plan Public } \\
\text { Workshop }\end{array}$ & $\begin{array}{l}\text { City of San Luis } \\
\text { Obispo }\end{array}$ & Workshop & $\begin{array}{l}\text { City/County } \\
\text { Library }\end{array}$ & $\begin{array}{l}11 / 19 / 2009 \\
6 \mathrm{pm}\end{array}$ \\
\hline
\end{tabular}


Table 3

Interviews with California planners

\begin{tabular}{lll}
\hline Interviewee & City & Population \\
\hline Planner One & Santa Barbara & 90,000 \\
\hline Planner Two & Sacramento & 463,000 \\
\hline Planner Three & Los Angeles & $4,000,000$ \\
\hline Planner Four & San Diego & $1,300,000$ \\
\hline Planner Five & San Luis Obispo & 45,000 \\
\hline
\end{tabular}

Note. Population Data from U.S. Census 2000

\subsection{Strategy for reporting findings}

Descriptive accounts of cases and interviews are provided in the following chapters. The outcome of this research is useful in determining what participation techniques are most effective and when to employ those techniques to expand community input on local government planning actions. Positive methods are isolated and used to inform a "toolkit" for effective public participation relative to the scale of government action, project or plan. 


\section{FINDINGS}

\subsection{Case studies}

Six hearings and eight workshops were observed from June 2007 to November 2009, for a total of 14 case studies. Firsthand observations of cases describe meeting format, attendance, space planning, visualization tools, and public input opportunities. Analysis of each case is provided that identifies successful participation techniques and why they were effective given the desired outcome of the meeting. Overall impressions on what elements contributed to a meeting's success or failure conclude each case description.

06/07/07 - Study Session: Santa Maria Planning Commission (H1). The City of Santa Maria held a morning Planning Commission study session in the City Council Building that was open to the public. The session was conducted exactly like a public hearing. The Chairperson opened the formal meeting with gavel in hand, and the public was given a window at the outset to address the Commission on any subject not on the morning agenda. The door remained open as late arrivals (staff and public) filtered into the meeting. Many people arrived minutes before their agenda item was heard and left immediately when discussion on the item ended. The major distinction between the study session and a public hearing was the absence of a formal motion being made by the Commission. The study session was meant to prepare the Commission for their regularly scheduled hearing on June 20,2007 , and also give staff an opportunity to gather early direction on projects. 
There were a total of 13 items on the agenda. Items were spread between five different planners who presented each item and responded to questions from the Commission. Total attendance was good with 24 people filling the room. Participants consisted of 10 staff members, 4 Commissioners and 10 public participants. Breadth of attendance was poor however, with limited representation from minority groups. At the end of two and a half hours only six participants remained (2 of which were late arrivals).

The conference room in City Hall had approximately 35 seats. Commission and staff were seated at an L-shaped table up front, while public seats were relegated to the back of the room. Staff had their backs to the general public. The space felt too cramped for the amount of attendees. Significant traffic in and out from staff members and various side conversations were distracting.

Visualization tools varied from posters to PowerPoint. Staff relied on project specific documents such as site sections, aerials and site plans to illustrate talking points. PowerPoint was the tool of choice to visually portray these graphics. At times staff relied on printed maps laid out on the table in front of the Commission or posted on the wall.

Dialogue was primarily between staff and Commissioners. Speaker duration was dominated by staff for 53 percent of the time, and the Commission who spoke 40 percent of the time. The public contributed seven percent of total dialogue. Opportunities to participate were few and the level of active participation suffered as a result. The meeting was conducted at a frenzied pace, which created visible stress for staff presenters. The public took a more 
peripheral role as listeners and observers. Body language of public attendees was attentive at first, but interest began to wane after an hour as evidenced by eyes darting around the room and people shifting in their chairs.

Most members of the public were stakeholders from the development community with business interests in the projects being discussed. They provided detailed descriptions of project design features when prompted by the Commission. Most projects were already in progress. The hearing elicited limited (if any) public input on actual changes to the projects. Public was not allowed to comment as presentations proceeded. Commissioners glossed over public comment, attributing an air of unimportance. Commissioners were more concerned with asking questions of staff.

The language of the hearing was formal and a bit alienating. "Madame Chair" or "Members of the Commission" was heard at the outset, which set the tone of the meeting. These auditory cues are intimidating for participants not familiar with public hearings. It gives the sense of being in a courtroom. Planners used too much industry jargon, which can defeat the purpose of government transparency. The public cannot be involved in planning actions that they do not understand. The meeting may have been strengthened with more education about the planning concepts that informed each project.

The study session was not a good example of genuine participation. Residents assumed the role of attendees instead of participants. Discussion revolved around staff presentation and Commission reaction. Limited public input came from developers providing additional project information. The setting further 
marginalized public participants because seats were arranged in the back of the room like a gallery, with main presenters turning their backs to the public.

One redeeming quality of the meeting was its stage in the planning process. The study session gave people an early opportunity to review and comment on projects before they reached the public hearing stage. The Commission could have suggested changes based upon this input, thereby providing instant gratification for community members. Unfortunately, Commissioners did not always realize this potential and instead rushed through public comments with a brief "thank you for your input".

10/17/07 - SLO Planning Commission Special Workshop (W1). The City of San Luis Obispo long range planning staff organized a special workshop to respond to the initial draft of a specific area plan. The target area was the South Broad Street Corridor, which is located on the periphery of the downtown planning area. The City's General Plan designated South Broad Street as an area of growth that should accommodate a diverse mix of housing types, offices, neighborhood commercial centers, parks and small manufacturing businesses. The South Broad Street Corridor Plan was developed to accommodate these General Plan policies, and implement form-based codes (FBC) for the area design. FBCs have never been used before in the City of San Luis Obispo.

The participation methodology used was a mixture of public hearing and community workshop. Fifty percent of the meeting was held in workshop format, with designated breakout tables and presentations from workshop participants. The other half of the meeting was formalized public discourse between Planning 
Commissioners and City staff. This period resembled the traditional public hearing process.

The location of the meeting was the City County Library Community Room, which provided ample space for conducting the workshop. Ten chairs were arranged around each of three breakout tables. An additional Commissioner table was set off to the side as a makeshift dais, and thirty-five gallery seats were available in the rear. The setting was flexible and all furniture was movable. Commissioners began the meeting at the dais, with staff centrally located and public in the gallery seats. All breakout tables were empty in the beginning, with the exception of staff facilitators. This arrangement clearly defined participant space and roles in the beginning of the meeting. These distinct boundaries began to blur as the meeting transitioned from public hearing to community workshop.

The approximate attendance reached thirty-two participants: six Commissioners, six City staff and twenty public participants. As the meeting progressed it became clear that the majority of public participants had a specific interest in the South Broad Street Corridor Plan because they were current residents or business owners in the target area. Many were members of a previous focus group on the development of the specific plan.

The Commissioners were the most vocal participants. They spoke sixty percent of the time in breakout groups, and forty percent of the time overall. The public spoke twenty percent of the time during breakout sessions, and fifteen percent overall. Both cohorts increased their participation once the meeting was 
transformed into a community workshop. City staff reduced their amount of speaking as the breakout sessions commenced, and also changed their style of communication. In the initial meeting stages, the project planner assumed the role of educator, presenter and instructor. During the workshop period, the project planner was a silent listener and other City staff acted as facilitator and recorder. This modification of roles mid-meeting exemplified a conscious shift towards a more communicative action approach.

The community workshop was structured to focus on three emphasis areas of the South Broad Street Corridor Plan: land use, circulation and FBCs. Each breakout table was assigned one of these general topics and given talking points to address and report back on in forty-five minutes. Two commissioners were assigned to each breakout table.

The visualization tools used throughout the meeting were varied. Staff presented a PowerPoint slideshow that integrated text, maps, tables and 3D SketchUp massing models. Copies of the PowerPoint slides, agenda with staff report, and the South Broad Street Corridor Plan were available as handouts. Each breakout table had large conceptual area maps, examples of successful FBCs from other cities, flipcharts, markers, pencils and highlighters. This multimedia visualization approach was very successful. Graphic tables and models helped clarify aspects of the specific plan, and flipcharts, large-scale maps and writing implements allowed participants to get directly involved in sketching and outlining conceptual feedback. 


\section{BREAKOUT GROUP: LAND USE}

The opening discussion of the group was about the value of FBCs. It was a heated discourse and the facilitator did not intervene. Talking points were outlined at the beginning but the group did not adhere to them.

Each group member established credibility early (i.e. professional planning experience, staff, SLO resident duration and proximity to development action). This was additional unsolicited information that was volunteered by each participant.

The first half of breakout time was dominated by argument between one Planning Commissioner and other group members. After all parties had aired out their grievances and complaints, consensus building could begin. The facilitator recognized the quiet person in the group and he got to speak his mind, which empowered his participation that was otherwise nonexistent up until this point. The most vocal participants were the commissioners, developer and affected resident.

The group agreed that FBCs were only appropriate for developing the "Main St" in the mixed-use core. Other generated group goals were general opinions on land use in the Broad Street area. Most talking points were not addressed.

Rotating staff sat in at times to help steer the group back to the objective of identifying outcomes for the specific area. The facilitator was hands-off most of the time.

Recordation of group goals was on flipcharts at the last minute. General bullet points were created that encompassed agreed upon group feedback. At the end, the most vocal Planning Commissioner presented group results to the larger group.

Overall impressions of the Planning Commission Special Workshop were positive. There were ample opportunities to participate, the presentation was clear, communication between planner and public was strong, and community ideas were being implemented. City staff effectively utilized a mixed method approach that incorporated physical interaction, oratory, active dialogue and small group collaboration. The one major drawback was the exorbitant length of the participation event. The workshop duration was scheduled for three hours, 
but the actual duration went well over four hours. Public body language implied a lack of interest in the lengthy staff presentation at the beginning, and the drawnout formal response from the Commission at the end. The community workshop would have been enhanced without these two structured bookends. Momentum was highest at the end of the breakout sessions and considerably lower when the meeting was formally closed. Attendance was also at it lowest because approximately forty percent of all participants left early after the breakout sessions.

11/28/07 - San Luis Obispo Planning Commission Regular Meeting (H2). The City of San Luis Obispo development review planning staff held the regular bi-weekly Planning Commission meeting to consider current development projects. The only item on the agenda was the updated design of the Chinatown mixed-use development project. City staff requested guidance from the Commission and members of the general public on the adequacy of the final environmental impact report (EIR). No action was taken by the Planning Commission.

The participation method used was a public hearing. After an initial presentation from City staff, contractors and architects, the general public was given a window of three minutes to speak out on the issues being discussed. No feedback was given from Commissioners or staff until after all public testimony was given.

The location of the meeting was the City Hall Council Chambers, which provided ample space for conducting the hearing. The setting was a lecture hall 
with fixed theatre seating. Commissioners were seated on a raised dais, which was the focal point of the entire room. City staff flanked the Commissioners facing inward towards the dais. The public was relegated to gallery seating that was below the decision-makers in the room. Power roles were apparent in the way the room was arranged; it was almost like the Commissioners were holding royal court over their subjects.

The approximate attendance reached fifty-nine participants; seven Commissioners, five City staff, two consultants and forty-five general public. This was a solid turnout largely because the Chinatown mixed-use development project is a highly contentious issue. It was clear that the majority of public comment was in protest against proposed demolitions associated with the project.

The Commissioners and staff were the most vocal participants. Both cohorts each spoke forty-two percent of the time. The public was the least involved,

\section{PUBLIC TESTIMONY: SAVE THE HISTORIC BUILDINGS}

There were no smiles in the Council Chambers. The mood was very dry and somber. The public waited 1 hour and 20 minutes before their voices could be heard.

Most of the public comment was pre-prepared and not specifically relevant to the stated purpose of the meeting. As comments proceeded, public testimonials got increasingly more emotional. All focus was on the proposed demolition of two historic buildings. The message was clear from the community participants: Preserve the Sauer Bakery and Blackstone Hotel buildings.

Long-time residents pleaded for the City to preserve the integrity, historical character, and legacy of their ancestors. The majority of public comment was negative reactionary testimonial from senior citizens. One gentleman commented that he did not "trust a simulation".

Comments ran well over the directed 3-minute time limit. 
speaking only seventeen percent of the time. The project planner assumed two roles: presenter and expert.

This public hearing happened in the middle of the planning process. There are still two more Planning Commission meetings to be held before the Chinatown project moves forward. Although the stated purpose was to gather feedback on the EIR, much of the public comment was negative reaction to an unrelated aspect of the proposed project.

The visualization tools were limited to PowerPoints and an agenda handout. Staff presented a PowerPoint slideshow of text and maps. The consultant PowerPoint incorporated text, maps, 3D Sketchup snapshots and a 3D flythrough animation of the proposed project. The 3D model was clearly the best method of visualizing the updated version of the Chinatown mixed-use development. However, one major drawback to using 3D graphic tools stems from the "digital divide". Participants have varying levels of technological understanding, which may influence their view of the credibility of a digital representation.

Overall impressions of the Planning Commission Regular Meeting were negative. The only redeeming quality was the high attendance level. Opportunities to participate were sparse, the level of active participation was low, and the communication flow between decision-makers and the general public was always one-way. There was no resolution of apparent issues and residents left the meeting with the same level of uncertainty that they felt in the beginning of the meeting. Judging from the disinterested public body language - three people were sleeping - the staff and consultant presentations were too long. The 
major flaw in the public hearing was that the objective was not achieved; the general public did not supply any input on the adequacy of the EIR.

The most interesting observation occurred during the break period immediately following public comment. This non-structured ten minute span turned out to be the best period of public exchange. Strangers engaged in discourse over community design, future visions for the community, and common historical connections. Major dissenters located one another to bolster emotions. Planners and decision-makers should have been privy to these informal discussions. Genuine participation occurred during the one portion of the meeting that was not "on the record". This fact alone speaks to the need for a more casual participation forum that allows for the free flow of ideas.

04/07/08 - San Luis Obispo Architectural Review Commission Regular Meeting (H3). The City of San Luis Obispo (SLO) Architectural Review Commission (ARC) convened in the Council Chambers of City Hall on a cool night in April. The Chambers were packed with a total of 75 people comprised of 64 SLO residents, 6 Commissioners and 5 staff members. All age cohorts represented (except children). There was only one item on the agenda that was broiled in neighborhood controversy: a debate over whether to construct a parking lot in Mitchell Park.

A sense of importance was conveyed in the Council Chambers. Fixed rows of padded "theatre" seats for the public faced the front of the room where staff and Commissioners were seated. There was a slight rise in the floor moving towards the front. Staff was seated perpendicular to public, facing one another across the 
room. The Commission was raised two steps up at front of room on dais facing public. This seating arrangement is symbolic of the division of power among individuals, and common to parliamentary chambers meant for decision-makers. There were windows on one side of the room, large double doors on the other, and a regular man-door in back. Three flags (Federal, State, local) adorned the corner directly behind the seated Commissioners.

Staff and Commissioners had computer screens embedded in glass topped desks, microphones, and nameplates. The computers were synched with the PowerPoint displayed on the audiovisual screen behind Commissioners facing the public. Good use of site photos, aerials, and overlays helped portray the extent of proposed parking lot improvements. Cameras placed around room were mounted to wall for local TV broadcast. Large-scale site plans posted on wall, agenda handouts, petitions and picket signs from public added project-specific information to the visualization tools at the hearing.

The chairperson opened the formal public hearing, governed by Robert's Rules of Order, with the Pledge of Allegiance, followed by public comment about items not on the agenda. Staff presented a project overview and a recommendation for parking lot approval by the Commission. The ARC questioned staff and then opened the meeting up to a public hearing. Each person that wanted to comment submitted a speaker card earlier in the meeting and the Chairperson called them up my name. Residents stated name, address, and then concerns. The Chairperson thanked each one, which was all the response given from Commissioners. After public comments, Commissioners 
deliberated and made a motion. The meeting ended with staff providing an "agenda forecast" of what is to be heard at the next regular meeting.

Dialogue was entirely directed to the advisory body members. Staff took up 20 percent of the time with the presentation, but participation was dominated by the Commissioners (40 percent) and numerous public comments (40 percent). There was substantial comment from residents for and against a new parking lot for the local Senior Center. Each side of the issue had one lead spokesperson (5 min), and everyone else was relegated to 3 minutes per person.

The Council Chambers were divided down the middle like two angry families at an ill-fated wedding. Participants representing opposition to the proposed parking lot outnumbered the senior residents who supported plans to amend the Mitchell Park Master Plan to accommodate new parking facilities. The proposed 12 space lot would replace an underutilized shuffleboard court and barbecue area.

The opposition was well organized and even

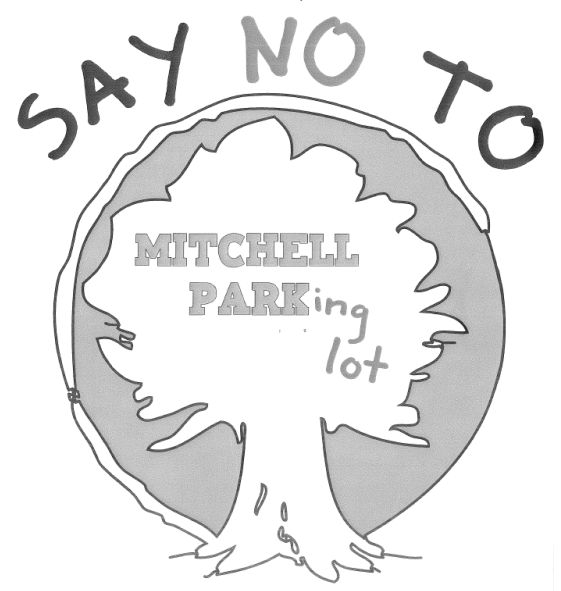

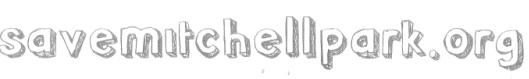
brought picket signs that read, "Say No to Mitchell Park-ing lot" (Figure 3) and "I Love Mitchell Park".

Figure 3. Picket sign in opposition to project.

They waved them in the audience when a resident would say something against the parking lot plans at the podium. A petition was signed by over 680 people opposing the parking lot plans. The seniors had their own petition with over 180 signatures in favor of the lot. They also provided emotional testimony about those 
patrons of the Senior Center with mobility issues, and how a parking lot would alleviate their struggle.

Interestingly, no one denied there was a problem. According to public testimony, the surrounding blocks are always impacted with parked cars early in the day, rendering it very difficult for seniors to access the building because they usually arrived later. Major dissension was over the City's solution to the problem. Many residents suggested alternatives such as Rideshare, parking districts, free bus passes, etc. It became clear as the hearing progressed that opposition was based on a fundamental belief that urban parks are precious and not a single foot should be paved over for automobiles. Idealism outshined realism as angry neighbors were quoting a Joni Mitchell song about "Paving Paradise" at the podium. For seniors, the lot was the most practical solution. They did not speak in favor of redeveloping parks or paving over the whole site. Instead they simply wanted a small area that was already underutilized to serve as exclusive parking for a public facility that has zero parking now.

Residents also spoke out about being informed too late in the process. The Parks and Recreation Department held a community meeting at the Senior Center over a year ago, yet many neighbors claimed no knowledge of it. It is apparent that some of the angst over the parking solution could have been avoided if better noticing and earlier meetings had taken place. There was little evidence community ideas were being implemented as the project seemed to already have been decided at this point. Construction of a parking lot was already identified as a "Major City Goal" in the City's Fiscal Plan, which was 
drafted a year ago. According to follow up staff interviews, the goal for a parking lot was adopted largely because the seniors came out in full force to previous hearings about what to include in the City's Fiscal Plan. Contrary to the staff recommendation, the Commission voted against the parking lot plans. They made a motion to the Council to either relocate the Senior Center or consider parking alternatives.

This public hearing was the most emotionally charged public meeting observed thus far. When issues hit home in people's neighborhoods, residents will go to great lengths to support or oppose the issue based on their personal interests. The neighbors opposing put together a website, www.savemitchellpark.org, and spoke with a unified voice at the hearing. Whether or not the Council hears this collective cry is yet to be seen.

Resolution of all apparent issues was not possible because the Council has the final call to be decided at a later date. This hearing was the second of five dealing with potential construction of a Senior Center parking lot. Level of active participation was high but coupled with public behavior and body language that portrayed anger and disappointment. The most interesting part of the whole public hearing was immediately after the formalities were over. Many residents that opposed the lot sought out seniors and tried to reason with them. Face to face communication occurred after the public participation event ended!

10/23/08 - Vision for Guadalupe 2030: Community Meeting One (W2). California Polytechnic State University's (Cal Poly) City and Regional Planning Master's Department was hired by the City of Guadalupe as a consultant team 
tasked with developing a community plan. The first public meeting in a series of five public meetings was held in the Council Meeting Room in Guadalupe's City Hall. The purpose of the meeting was to learn community desires and educate the public about general plans.

A good turnout of 40 people attended the meeting comprised of 24 residents, 3 Council members, and 13 Cal Poly consultants. This may have been a result of extensive outreach: flyers were handed out in-person on the streets and at public schools, and included with prior month's water bill. The meeting was also posted on the City's website.

One moderator led the two-hour meeting with support from a translator for Spanish speaking participants. After a brief introductory presentation, the majority of the meeting was reserved for breakout tables where Cal Poly facilitators guided discussion of community interests amongst small groups of residents. Four large rectangular tables were arranged at the back of the Council Chambers, sectioned off from the dais by a movable wall. One discussion table was designated for Spanish speakers. Three Cal Poly consultants staffed each table (facilitator, recorder and note-taker).

Tables were self-selected and ended up slightly segregated. The Spanishspeaking table was mostly residents of Latino descent. The City Manager chose to sit with the two Council members and a consultant who works for the City. The other two tables were a good mix of ages and ethnicity. Every generation was represented from young adults to retired seniors. Varying classes of society 
could be inferred by the different clothes people wore; service men mixed with executives through a common bond of citizenry.

There were multiple visualization tools including a portable digital projector, PowerPoint, flip-chart easels for group note-taking, aerial photos and maps on boards. Groups were encouraged to mark up posters with markers. Participation was guided by small group activities such as a "wish list" exercise and a "likes, dislikes, and changes" exercise.

The structure of the meeting was informal. The workshop was designed to get participants talking about their community. Each resident completed a wish list of ten or more things they want to see happen in Guadalupe. Small groups of six used these initial brainstorms in a subsequent three-part exercise:

1. What do you like about Guadalupe?

2. What do you dislike about Guadalupe?

3. What improvements would you like to see in your community?

Facilitators began breakout sessions with a round of introductions. This helped reduce the uneasy feeling of talking openly with strangers. People used personal stories to establish credibility when making claims. "I've lived in Guadalupe for 14 years, and I can remember when..." Discussion questions were posted on PowerPoint slides to remind people of the focus of the meeting. Laughter was evident when people talked about likes, and heated discussion was observed when talking about dislikes. Proposed improvements/solutions were similar to stated needs. 


\section{SMALL GROUP PRESENTATION: TOP FIVE IMPROVEMENTS FOR GUADALUPE}

The discussion tables were all buzzing with excited conversation. The setting enabled face-to-face interaction amongst participants around the table. This equalized the playing field between Council member and average resident. Roundtable discussion promotes direct eye contact among all participants, which can be more direct and less confrontational.

As the timed discussion came to a close the moderator announced that each table should select one member to present back to the whole with their group's list of top five improvements. A wireless microphone synched to a portable amplifier was given to the first presenter. Starting with what the group liked about their community and moving next to a list of improvements, you could see the pride in his eyes. The whole room clapped when he finished. Passing the microphone from group to group gave people a sense of ownership of the meeting. Lighthearted laughter and clapping continued as each group weighed in on Guadalupe's ideal future. Public speaking can be intimidating in a formal setting, but when the mood is casual it can be a powerful tool for establishing community ownership.

The consultants took notes on flip charts for everyone to see, and summarized all input into a list that reflected the general consensus: beautify downtown with consistent facades and lighting, redevelop Leroy Park, fix a dangerous intersection, enhance access to Santa Maria, and create more spaces for sidewalk cafes. The meeting ended on a very positive note with smiles and head nods spreading over the crowd.

Participants were also asked to prioritize their most important ideas for the future of Guadalupe. One member from each group presented small group findings to the larger whole. Refreshments (water, coffee, snacks) were available throughout.

Speaker duration was 63 percent public and 38 percent consultants. There were good opportunities to participate and the level of active participation was high. Public behavior and body language was positive, but a bit apprehensive. Even though participants enjoyed being involved, there was some skepticism over whether their opinions really mattered. This being the first meeting in the 
early stages of the visioning process, it is reasonable to assume that trust had not been achieved. There was also a general feeling that some of the suggested ideas were not attainable. Everyone at the meeting was very aware that the City was hurting for financing.

Nevertheless, the Vision for Guadalupe Community Meeting was a successful workshop that hit on many of Sanoff's principles for genuine participation. There was cooperation among participants that led to partnership in formulating group priorities. The planner (Cal Poly) acted as a facilitator instead of an arbitrator, which helped delegate power and foster citizen control. The end result was community empowerment, even if it was only for the short duration of the public workshop.

11/20/08 - Vision for Guadalupe 2030: Community Meeting Two (W3). The second meeting held by Cal Poly in the Council Meeting Room of Guadalupe City Hall was a continuation of the community plan visioning process begun in October. This meeting took on a different format relying more on presentation and less on group collaboration. The purpose was to report out on background research and receive critique from the community about facts presented.

Total attendance was comparable to the first meeting, with 36 people participating. 23 interested residents from different age groups and ethnicities stared intently at the succession of slides. 50 percent of attendees were recognizable from previous meeting, including two Council members. This was also the first time Mayor Lupe Alvarez was in the audience. Everyone in the room 
felt his authoritative presence, as he was one of the most recognizable longtime residents of the small town.

Two of the 13 Cal Poly consultants were presenters, one being the same moderator as last meeting. They switched back and forth between elements to break up the lengthy PowerPoint. Each "element" of the Community Plan was presented in four to six detailed slides with projections about emerging directions at the end. Issue areas discussed at the first workshop took shape as distinct elements of the evolving Community Plan: Economics and Demographics, Housing, Circulation, Noise, Parks and Recreation, Public Facilities, Community Design and Land Use. Each element was described at a separate poster table stationed with a Cal Poly consultant available for questions after the formal presentation. Markers were available for any additions or changes. Other visualization tools were a portable digital projector, PowerPoint, aerial photos and maps on boards.

The consultants reported findings based on a land use inventory, research and previous community input. The meeting was dominated by one-way communication from presenter to audience. Opportunities to participate were limited to welcome interruptions from public questions. The Mayor made two observations about the source and credibility of facts and figures. One presenter handled these inquiries well by thanking him for the input, but the other presenter got defensive. The consultant seemed very sure of his data sources, yet he neglected to rely on one of the most important sources of information: participants. 
The PowerPoint was information heavy. The audience was engaged but passive. Fear of stopping the presentation to ask questions may have deterred some from active input. Attention spans waned after an hour. More opportunities up front for public discussion were needed.

The poster sessions that followed granted more opportunities for genuine participation. Communication opened up when lighting changed, and participants stood around with consultants and other residents to discuss the facts. Some just looked at the posters without comment. Dialogue often deviated from information displayed on posters to personal opinions about the state of the community. Consultants jotted the following ideas down on blank space reserved on each poster for feedback:

1. Provide a community center (Quincienaras celebrations, parties, and other activities).

2. Shared parking would be beneficial downtown so that the parking requirements are not as high for each business.

3. Encourage housing near Guadalupe Street, but the ground floor along the street should be reserved for other uses.

4. The flooding behind the Far Western Restaurant forced houses to be removed.

5. Reroute and prohibit big trucks on residential streets (especially in the north side of the City).

6. Public facilities should be improved (schools need better playground design). 
7. There are too many loose dogs, which makes walking unpleasant. A dog park could be a solution.

8. Budget cuts took away the sports bus that shuttled kids to sports games in Santa Maria, so parents have to drive their kids there. Parents would like to see the sports bus brought back.

9. Bike races pass through Guadalupe on Highway 1 occasionally. The riders make pit stops at Leroy Park, so we should improve it.

These additional contributions help put a public face on general topics such as circulation or housing. The level of active participation increased during the poster sessions as public behavior and body language became more relaxed. The informal mixer gave participants a chance to evaluate concepts being discussed earlier up close. Contributing new ideas and seeing them written down on posters enabled a degree of resolution of apparent community issues.

The meeting ended successfully. The presentation during the first half was lengthy but effective public education about community sentiment gathered from the October $23^{\text {rd }}$ meeting, a Land Use Inventory and policy research. This data helped define "emerging directions" for Guadalupe that informed the development of the Community Plan. A second important purpose of the meeting was generating input. Consultants made sure that what was being proposed in the Plan thus far adequately reflected the community's interests.

Cal Poly consultants spoke more than 67 percent of the meeting, yet genuine participation did occur. This meeting was good evidence that participation comes in different forms: education of the public can be equally as important as 
engagement. Community input was more effective at the poster tables when ideas were stirred by a detailed presentation. Finding the balance between education and engagement proves to be crucial in achieving effective public participation.

02/05/09 - Vision for Guadalupe 2030: Community Meeting Three (W4). A third meeting focused on the policymaking stage of the Guadalupe 2030 Community Plan was held in the Senior Center three months after the first workshop. Attendance dropped to 29 participants, 13 of whom were from Cal Poly. Two presenters introduced draft goals and objectives based on previous meeting input and outside research. Emphasis was placed on showing how public input translates into policies and programs in a community plan.

The setting was a bright and clean community room with small tables. Seats were arranged in rows for the presentation. The projector and screen occupied one side of the room. After the presentation, seats and tables were pushed into center to allow for discussion around poster boards. The method of interaction shifted from oratory and listener to active dialogue in standing posture while enjoying more refreshments.

There were too many CRP consultants at the meeting. Planners almost outnumbered participants, which is a bit intimidating. The Mayor was in attendance, which added a degree of formality to the proceedings. Breadth of attendance was slightly above average.

Visualization tools consisted of a portable digital projector, PowerPoint, aerial photos and maps on boards, and text-heavy posters displaying goals and 


\section{TURNING FEEDBACK INTO POLICY: THE ART OF WORDSMITHING}

The presentation showed how public input is translated into policies in a plan. Example:

Public Input: Target growth along Guadalupe St.; walkability

Goal: Transient-oriented infill downtown in the vicinity of Guadalupe Street

Objective: Develop all vacant land in downtown core by 2030.

This "show your work" exercise shifted ownership to the community residents in attendance. The Planner's purported role was facilitator. A feeling of disbelief was apparent among participants. Few people had attended previous meetings and some were skeptical about far-reaching goals. The Mayor set the tone by reminding CRP facilitators that there was no funding for some of the proposed programs. It doesn't cost anything to write down objectives, but to what extent they are attainable is valuable to residents. Some project credibility was lost.

objectives. The presentation was one-way communication informing the attendees about the project's progress. Good use of images helped soften technical data and help participants identify with concepts. Images were a mixture of photos and Internet downloads.

Reporting as the community plan document is being created helps maintain transparency, thereby establishing community trust in the planner. Participants were free to ask questions and provide feedback during the 40-minute PowerPoint slideshow. The follow-up poster session displayed goals, objectives, policies, and programs in written form for public to review and comment to CRP consultants. Public to public dialogue was rare. Speaker duration was 60 percent Cal Poly and 40 percent public.

Participants felt more comfortable asking questions in the poster session than during the PowerPoint. Limiting overall presentation and increasing small group discussion may have increased active participation. However, a certain 
cohesiveness of focus was lost during poster session. Off-topic conversations were common. A sense of importance is attached to a formal presentation. Participants come to give input, but are also largely motivated by a desire for information.

As the Guadalupe Community Plan progresses the workshops become more like a public hearing. Given the master document is being compiled, more reporting is expected. The easiest way to gain feedback is to speak directly about key topics of the plan. Communication in the meeting was focused and direct without any group exercises. This pushes the meeting out of the clear-cut workshop category towards public hearing. Lack of formality and loosely structured poster sessions take away from hearing status. What is the happy medium?

02/26/09 - Vision for Guadalupe 2030: Community Meeting Four (W5). Progress on the Guadalupe Community Plan was presented to the public at the fourth public workshop. The meeting began with a formal presentation from Cal Poly representatives designed to educate the public about three plausible alternatives. Participants then had an opportunity to discuss what was presented at group tables. All groups selected one of the alternatives or a hybrid approach and reported back to the larger audience.

The Senior Center's community room was bright and filled with large tables. Seats were arranged around tables to facilitate discussion among participants. A projector and screen took up one corner of the room. Attendees signed in at a 
reception table at the entrance staffed with a greeter. Seats were movable and many had to reorient them to face the audiovisual screen during the presentation.

Attendance remained consistent with the previous meeting with almost a one to one ratio of Cal Poly consultants to participants. Sixteen residents including the Mayor combined with 13 from Cal Poly totaled 29 people. Most age groups were represented.

The meeting was a mix of formal presentation and breakout tables. In the beginning, three presenters spoke about growth alternatives based on goals and objectives from previous meeting and projections. The 35-minute presentation established three different choices for small groups to consider. Breakout groups discussed the merits of varying approaches to growth using face-to-face interaction at tables. One member from each group reported back to whole room on what was discussed. The purpose was to facilitate community discussion about which development scenario is best for Guadalupe: Existing Trends, Moderate Growth or Comprehensive Growth.

Speaker duration was an even balance between planner (45 percent) and public (55 percent). The Mayor was once again present at the meeting, and used the opportunity to question some of the information presented. He wanted to make it clear that the alternatives suggested by Cal Poly were only aspirations, and that there wasn't enough financing to support some of the concepts being discussed.

Visualization tools were a portable digital projector, PowerPoint, aerial photos and maps on boards, and Google SketchUp models of each growth scenario (in 


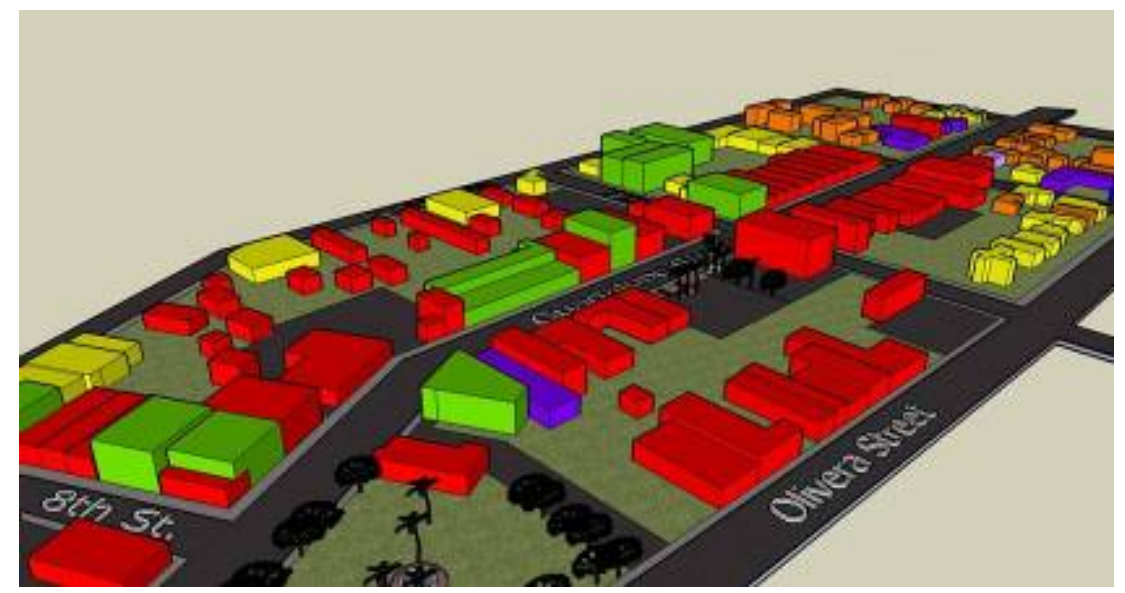

Figure 4. Guadalupe massing model.

Note. Reprinted from Cal Poly CRP presentation, February 26, 2009

PPT and color prints at tables). The three-dimensional SketchUp models were extremely effective at demonstrating potential massing downtown with different levels of density. Figure 4 is a screenshot from the Guadalupe 3D massing model.

Concepts such as density and building height do not resonate as well in the absence of tangible images. The models helped people grasp exactly what some of the draft polices actually mean in the context of downtown Guadalupe. One drawback was that models did not have any more shape than simple boxes. The addition of some building features - especially on existing buildings - may have helped participants identify with the visual representations more.

Statistics and tables had the least impact on participants. The presentation relied heavily on projections and data tables to quantify growth for each alternative. It was apparent from body language and lack of questions from the audience about these numbers that the message did not come across. The clarity of the presentation was muddled and seemed to focus on Downtown 
strategies more than previous meetings. Perhaps this was because the massing study only modeled Downtown.

There were many opportunities to participate and the level of active participation was high. All breakout groups arrived at the same conclusion (consensus)! Moderate Growth was preferred over other alternatives. This seemed likely from the outset because it is the common sense choice. For a town like Guadalupe, where growth is stagnant and diminished from previous years, moderate growth seems most viable. Not may people will support comprehensive growth since it is a drastic change.

Even though the identified focus of the meeting was discussion about alternatives, the conversations at breakout tables drifted towards community desires. Each table had a facilitator, and rather than stifle conversation, they went with it. It seems that many community members wanted to put their concerns about Guadalupe on the table. This is what people are most familiar with and where passion lies. It is up to the facilitator to guide discussion, but an important crossroads that each facilitator had to face was when to try and keep comments on track or when to let dialogue continue. The risk of too much facilitating could be silence from participants!

03/12/09 - Vision for Guadalupe 2030: Community Meeting Five (H4). The final public meeting in the work effort to develop a Guadalupe 2030 Community Plan was held in the Senior Center on a chilly March evening. Attendance was the lowest out of all the meetings, and for the first time Cal Poly 
planners outnumbered community members. 23 people attended including 10 residents, the Mayor, and 12 Cal Poly consultants.

The level of dialogue was exclusively one-way communication between consultant team and public. Opportunities to participate were limited. Four planners presented the completed Guadalupe Community Plan, which was the culmination of the public meeting series and Cal Poly writing efforts. The informational session that was open to questions throughout. Brief pauses for responses broke up an otherwise lengthy oral summation of the plan document.

Movable chairs in rows focused participants towards an audiovisual screen. Attendants self-selected seating; the Mayor chose to sit with a Planning Commissioner. The sterile white community room contained large tables, one of which was used as a reception table with sign-in sheet at the entrance. The refreshment table was in back of room located in the same spot the previous meetings.

The final presentation of all research, analysis, policy and meeting outcomes relied on a portable digital projector, PowerPoint, and Google SketchUp digital massing models to convey information to the community. Planners spoke 50 percent of the time as opposed to 13 percent public input and 37 percent socializing. An open house atmosphere evolved after the formal presentation. The meeting resembled a hearing without designated rules of conduct.

Consultants placed considerable emphasis on reiterating the communitybased nature of the project. Despite its apparent complexity - goals, objectives, policies, programs - the plan originated in public sentiment. At this stage it is up 


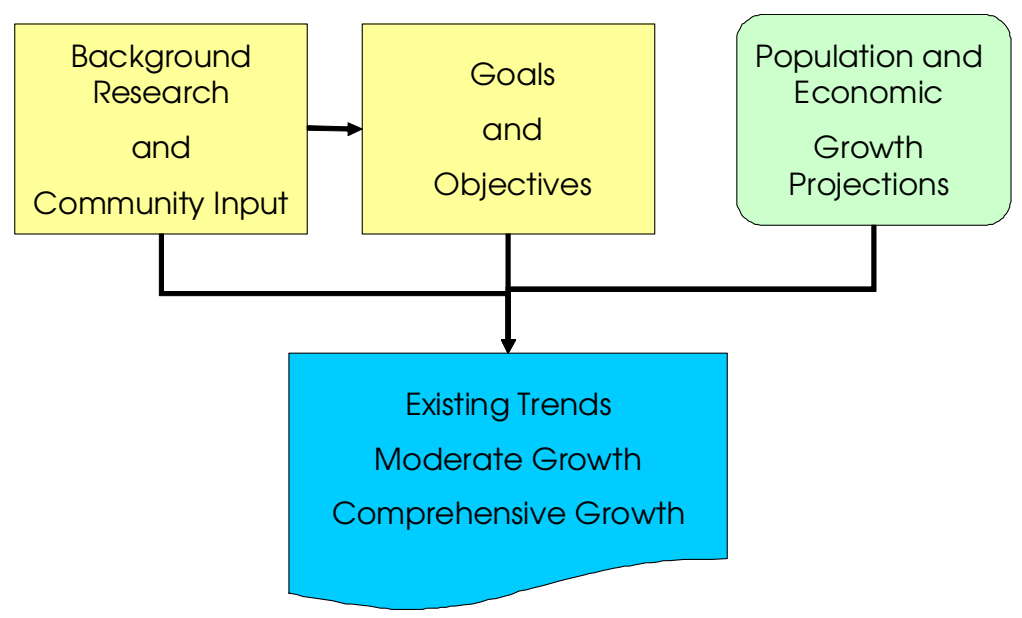

Figure 5. Flow chart of a community plan.

to the community and its leaders to see it forward towards implementation. Flow charts were helpful to catch up participants that had not attended previous meetings. Figure 5 shows the chart used at the Guadalupe workshop.

There were few repeat attendees but still a decent mix of representatives from different sectors of Guadalupe's town fabric. The act of gathering is a key variable of effective participation. Good discussion occurred after the presentation while standing around with refreshments. Public behavior and body language was positive. Many municipalities have been moving towards webbased gatherings, yet face-to-face communication is lost in technology. A person has limited comprehension of a sense of "gathering" from a webinar statistic that indicates 500 participants. At a workshop people get a "hands-on" understanding of the plan and a chance to get direct answers in an informal environment. The resolution of all apparent issues and implementation of community ideas is apparent and tangible.

The meetings were successful, yet could have reached a larger demographic. They were always held at a City building in a community room after work, with 
same basic refreshments. Other ideas are to hold a meeting at a school gymnasium during the day, on a weekend in a Park facility, or even organize a "screening" of the plan in a local theatre. The following is a list of stakeholders present at various times during five meeting series:

1. Guadalupe residents (all cohorts)

2. Mayor

3. Officials (Planning Commission, City Council)

4. Peoples Self-Help affordable housing developer

5. Community Plan consultant team - Cal Poly

6. Guadalupe planning staff - Rincon Consulting

7. Planning students

8. City Manager

Each new meeting was a step down Arnstein's ladder away from citizen control. Presentations became increasingly detailed and participants assumed a more passive role. Involving people in the early stages is easier because topics are general and conceptual. Is this inevitable as ideas transition into policy statements or tangible design? The planners may have managed expectations better by framing meeting titles: workshop implies gathering to work on something together, hearing implies listening to something, usually an action that may affect you.

Overall this was a successful participation effort that achieved genuine participation early in the planning process. As the project drew closer to the end product, participation shifted away from interaction towards reaction. Questions 
changed from "How do you feel" to "How do you want to grow" to "Did we get this right”.

\section{6/15/09 - San Luis Obispo County Budget Hearings - FY 2009-2010} (H5). 2009 budget hearings for the County of San Luis Obispo occurred during the month of June at the County Government Offices. The task of balancing the budget proved to be a difficult task given the state of the economy. The five Board of Supervisors reviewed staff's proposed budget presentations at 9 am in the morning and made the difficult decisions on where to cut County resources.

There were 50 people in the audience and 10 Supervisors and staff seated around the raised dais at the front of the room. Eighteen attendants arrived late, including the media who arrived around 10 am. Most dialogue was staff communicating to the Board about proposed budget cuts. Staff from different departments made eight separate 30 minute presentations that educated public and Supervisors about repercussions of the troubled economy. Subsequent questions arose from the Board of Supervisors to staff. Contact between staff and public was filtered through the Board; when the public asked questions the Board would look to staff for answers. Staff spoke 69 percent of the time, the Board 27 percent, and the public only 3 percent.

The County Chambers was an air-conditioned round room with no windows. Public sat in fixed theatre-style seating facing the raised dais where Supervisors and staff were seated. The dais was large enough to fill one-third of wall space. A large audiovisual screen was mounted behind board members that showed a live video feed, PowerPoint presentations, and a digital timer to monitor public 
comment. Supervisors followed along with the presentation on monitors embedded in front if them in the dais. It seemed they were constantly looking at their computer screens instead of making eye contact with the public or staff.

Audiovisual can be very helpful, but too much automation can be distracting as well. Each participant was given three minutes to speak and a giant screen with a flashing clock counted down the time. The font changed from green, to yellow, to red as time ticked down. This was visually distracting to public speakers and also sets the tone that the Board is placating participants.

During staff presentations, department heads took turns reacting to proposed budget cuts. Ironically, discussion occurred about impacts to the public, yet residents were given little chance to respond and it did not seem that residents were involved in the initial decisions. The standard answer from staff was that, "things will take longer".

Even though attendance numbers were large, the County Chambers were only 50 percent full. There was no diversity in the audience. Ninety-five percent of attendants were white, middle-aged professionals in suits, ties, and dresses. Public behavior and body language suggested that many audience members were required to be at the hearing. Greetings among people in audience and visual recognition implied that they come to Supervisor hearings regularly.

The tone of the meeting was somber and the audience was quiet. The sound of hushed whispers and the occasional disruptive sound of a cell phone ringing permeated the gallery. One PowerPoint slide was light hearted to garner a few laughs but the Board remained resolute. The first hour was predominately staff 
presentations with the odd clarifying question or comment from a board member. After 50 minutes the public gave the following input:

Resident \#1: Prepared statement critical of budget cuts

Resident \#2 (Host of government watchdog radio-show): Adversarial comments about how the budget is not business friendly

\section{Resident \#3 (Representative from agricultural community): Prepared} statement about inequality of giving Planning department a small increase

The meeting was solely educative: inform the Board about budget decisions, and inform the public about budget implications. There was no input from the public on whom or where to cut (perhaps this happened at an earlier meeting). The hearing appeared to be towards the end of the process. Staff and the Board were essentially telling residents what decisions were happening. Communication was a one-way flow, which stifled opportunities to participate and the level of active participation. Too much text on slides made the presentation too long. It was apparent that the audience was bored because there were many shifting eyes trying to identify others in audience and focusing their attention elsewhere. Even though the public participation event was focused more on education than gathering input, improvements in format, information presented and time management would have made the meeting more engaging.

06/16/09 - Special Joint Meeting: Atascadero City Council \& Planning Commission Workshop on 2009 Housing Element Update (H6). Every five years a municipality updates the Housing Element of the General Plan. It is a requirement of State law. Many cities schedule workshops and hearings to 
evaluate current policies and develop new directions in Housing programs. The City of Atascadero held a "Workshop on the 2009 Housing Element Update" on June 16th, 2009. It was a special joint meeting with ten members of the Planning Commission and City Council in attendance. After five minutes it was readily apparent that the meeting was more hearing than workshop when the Pledge of Allegiance was recited and the Chair began the proceedings.

The setting was the Council Chambers at City Hall, a former bowling alley located near the historic city centre. The large dais was the main focus of the room, positioned opposite rows of folding chairs on the same floor level. This was the first public hearing observed without a raised dais! This helps eliminate apparent differences in power. In the center was audiovisual equipment on tripods operated remotely from a monitoring station setup on a table at the back of the large assembly. The speaker podium was off to the left of the sprawling semicircle of Council members, where the hired consultant for the City of Atascadero presented the Housing Element Update process in detail. Twentythree total attendees of the workshop included: ten from the general public, three staff, seven Planning Commissioners, and three Council members. Demographics were middle-aged white.

Dialogue was mostly one-way communication between the consultant and the advisory board. The presenter described it as a kickoff meeting for the Housing Element update. Stakeholder interviews had been held prior to the meeting to solicit feedback on the Element. The presentation was digitally projected on a screen positioned in the right corner of the room. Members of the advisory bodies 
and general public focused all attention on the PowerPoint presentation, predominantly comprised of text filling the entire screen. Graphics were used occasionally in the form of tables and graphs. These slides were easier to visualize and prompted more questions from the Commission and Council members.

After 30 minutes, members inquired about technicalities and asked for clarification of the facts presented. Of particular interest was the Regional Housing Needs Allocation (RHNA) of affordable dwellings that Atascadero needs to meet in the next planning cycle to have a certified housing element. One Councilmember flat out said, "What if we tell the State, we ain't doin' it!" Others questioned about what qualifies as an affordable dwelling. Questions and answers on this topic continued for an additional thirty minutes. At this point the meeting was going off-track. The consultant did not fill the roll of mediator, only presenter. The Chairperson did not effectively keep comments focused on overall Housing Element update project, and instead joined in tangential discussion about whether RHNA was fair or even desirable for the City of Atascadero. Eventually, the consultant presentation continued, and after one hour and a half the public got its first chance to speak.

Public comment came from developers working in Atascadero. Each had about five minutes to speak, and almost every person was adversarial. The first person from the public to speak was adversarial in nature and concerned solely with his own project that was still working its way through a lengthy planning process. It happened to be an affordable housing project so the topic was 
somewhat on point. As his time at the podium progressed he became increasingly more agitated and started shaking his finger at the Planning Commissioners. He claimed they had "stonewalled" against developers bringing affordable projects forward. He ended with raised voice, flushed face, stating that the Planning Commission had a "personal vendetta" and loudly questioned "What about my projects?" The Chairperson (mayor) cut him off. The remaining participants who commented were all developers as well. They had vested interests in the Housing Element policies. Instead of suggesting new alternatives, the second person to comment expressed concerns about the difficulty of building affordable housing projects with no soft money from the City. This was solid input from the community that should be addressed. The Council simply nodded and asked for the next speaker. The third and fourth comments came from developers complaining about City fees and requirements for engineers to be certified. Public comment closed with the first developer back at the podium shaking his finger and telling certain members of the Planning Commission to "Beat it!"

Though these comments were critical, they were not motivated by NIMBYism. Participants were stakeholders in the Housing Element update process because the housing policies being drafted affect their business's revenue stream. Desire to improve the community was apparent, but frustration was the defining emotion being conveyed to the Council members.

Public input was retained and commented upon briefly by staff and advisory members. Members listened intently to the public, which gave participants a form 
of social validation. The small act of speaking out in front of a microphone and having the ears of the decision-makers grants some satisfaction. The "workshop" reached its final stages as the Commissioners and Council members entered into deliberations. This is when each advisory member had a chance to give uninterrupted input about the information presented and the state of housing in general in Atascadero. After no motion was passed, the consultant provided details about the next public meeting in the Housing Element workshop series. The workshop formally adjourned.

In a public setting with all eyes on the dais, it is apparent that Council members feel compelled to speak up about something. It is almost as if they do not feel they are fulfilling their role unless they have some comments. This is good because the public gets a chance to be party to a transparent decisionmaking process that is happening before their eyes. The fault is that the public is passive in the discussion. Assuming a more voyeuristic role, residents have to sit idly by and wait for their timed opportunity to give input. Unfortunately, often times this input is pre-prepared and unrelated to the focus of the meeting.

Even though the meeting was billed as a workshop, it was a clear departure from the loosely structured collaborative environment of Sanoff's workshop definitions. This hearing was a classic example of what local governments contend is a workshop, but very far from the truth. Municipalities get stuck in the realm of Robert's Rules and forgo key elements that make a workshop true to form: people talking face to face in a small group environment with an absence of titles and power struggles. 


\section{8/18/09 - City of San Luis Obispo Preservation and Design Review}

Workshop (W6). The City of San Luis Obispo organized a two-part workshop to provide training to the Architectural Review Commission and the Cultural Heritage Committee $(\mathrm{CHC})$ on historic preservation. It was an open meeting that the public was invited to attend. Twelve advisory body members, nine staff and five residents came to a 2-hour evening presentation and 4-hour workshop/training the following day.

Winter \& Company, a consulting company from Boulder, Colorado, moderated the meeting. The workshop provided participants an overview of historic preservation and ways to implement it through design review. The consultants educated regulators (not consumers) on how to identify key building features and design principles. The goal was to help workshop participants define "historic character".

The evening session was a presentation held in the City/County Library community room consisting mostly of the speaker's first person accounts of historic preservation efforts in Boulder, Colorado. Movable seats were setup diagonally creating rows. Advisory body members and staff filled first two rows on either side of screen. There were two tables for the ARC and $\mathrm{CHC}$ members with their nameplate prominently displayed. Public were seated in an ancillary location behind staff/members.

On the second day dialogue shifted from presenter and audience to small group discussion with group member reports. It was organized like a retreat for $\mathrm{CHC}, \mathrm{ARC}$ and staff. Tables were rearranged to create small groups and 
refreshments were served in the back corner (cookies, coffee, and water). An introductory lecture provided more information about historic preservation, followed by small group exercises where participants applied principles being discussed. Ample time was given for discussion at breakout groups. At the end of each exercise one member from each group presented a brief description of table discussion.

Visualization tools included PowerPoint, an audiovisual screen, flipcharts, group exercises (4), and agenda packets. No note-taker was assigned yet each group had someone who self-selected. Space was provided on exercise sheets for listing ideas. Almost all contributions offered from participants were written down.

Even though the Preservation and Design Review workshop was open to the public, it was really designed as $\mathrm{CHC}$ and ARC training. Members of public in attendance were stakeholders "in the business" of historic preservation (architects, designers, historians). The subject matter, however, was universal. Consultants presented "lessons learned" that were not contextual to the San Luis Obispo area.

Group exercises incited focused discussion about architecture and design. Photos were printed on $11 \times 17$ paper depicting "then and now" snapshots of a particular building. Discussion started with clarification of group assignment and inspection of photographs. People were uncertain about exactly what was portrayed in historic snapshots. Groups then identified key building features both 
current and historic to help guide a restoration plan. Subsequent exercises expanded the group's focus to whole blocks or historic districts.

A distinct element of the workshop was focused discussion. Participants did not offer personal stories or voice concerns. There was limited opportunity for opinions or debate. Primary interaction centered on the task given to the group. A communal assignment neutralizes preconceived notions associated with class, standing, or power. Dominators in the group arise from knowledge of the subject matter instead of job description.

Small groups had no introductions at tables. Each group went right into problem-solving without establishing identities. It was evident that everyone at the table was familiar with historic preservation and architecture when words like "quoin" and "cornice" were tossed around. Those that showed up to the workshop had vested interests or background in the subject matter. Are these the people that benefit most from an introductory workshop on historic preservation? Or are they the only residents who care to participate?

At the end of the whole training/workshop, participants were satisfied. One gentleman made a point to state, "great workshop" to anyone near him. Everyone who attended participated, and all clapped and thanked at the end. Public behavior and body language was positive. Interestingly, speaker duration tipped towards heavy public input. This was due to the fact that advisory body members became community members, and the lines were blurred at small group tables. All participants were united by a common desire to learn more about the topic being discussed. 
09/10/09 - City of San Luis Obispo Housing Element Workshop (W7). The City of San Luis Obispo held a workshop focused on the update of their 2009 Housing Element. Like Atascadero, the City of SLO was going through their State mandated five-year update to housing policies and programs. Two staff members presented to a small crowd of 7 people consisting of 3 residents and two additional City planners. This was the second workshop in a series of four meetings.

Seating was arranged around circular tables in the Community Center meeting hall. Everyone turned their chairs to focus on the presenter standing by screen. Refreshments in the back corner of room (water, grapes, cookies, and juice) were available during one specified break. Participants picked up an agenda from a stack by the presenter when the meeting began.

The main component of the event was the presentation. An opinion survey was handed out midway with housing specific questions. Limited public involvement took the form of questions about facts presented or City efforts on various topics such as affordable housing. Staff spoke 75 percent of the time versus 25 percent by the public participants. Staff presenters took turns to break up the presentation. There was no opportunity for face-to-face interaction amongst public. The only visualization tools were a PowerPoint, projector and audiovisual screen.

Overall the presentation was informative and data heavy, with 30 minutes of bullets and charts about demographics and housing statistics. A few questions broke up a multitude of slides that were hard to read at some times filled with text 
and lacking graphics. There was no summation of the last workshop for new attendees, and no discussion of input from previous workshop comments and the effect they had on development of the document. This prevents ability of community to take ownership of the plan. The "workshop" also lacked group exercises and games designed to engage participants.

The fact that the meeting was sparsely attended set it up for failure. Few community interests were represented and the breadth of attendance was poor. More excitement at the workshop may have attracted more participants, but the time and day conflicted with a major community event (SLO Farmer's Market). Everyone that did attend worked in a housing related field (People's Self Help, Housing Authority, and County Planning). It was as if the City had sent out a meeting request through an Outlook calendar. Staff presence was overbearing (two directors, senior planner, and associate planner) relative to public attendance.

Implementation of community ideas was nonexistent. The presentation was about policies that had already been decided before the workshop. Public engagement came late in the Housing Element update process, and was not genuine participation as Sanoff describes it. The meeting was an opportunity for the public to evaluate policies, but there was too many to consider in one meeting. Furthermore, the average person would not be able to answer many of the opinion survey questions without extensive review of the draft document beforehand. Figure 6 is an excerpt from the opinion survey. 
The SLO workshop was a perfect example of a phrase commonly heard among the halls of government offices: "This is the way it has always been done". For a society that has evolved to become visual-based thinkers reliant on technology, opinion surveys and lectures don't cut it any longer. Staff did not go for lack of trying. Overwhelming workloads among public sector employees influence the amount of time that can be attributed to organizing a good public workshop. Combined with a lack of funding it becomes clear that public participation events are overlooked. Is this a product of the cynicism from planners about people's interest in the Housing Element? What are the budget allocations for participation events? How can local government planners make it more exciting than cookies and water?

\section{Comment}

2. The proposed Goals, Policies and Programs include what I believe are sufficient actions or measures to meet the City's most important housing needs.

\begin{tabular}{llllll|}
1 & 2 & 4 & 5 & 6 \\
\hline Strongly agree & $\begin{array}{l}\text { Moderately } \\
\text { agree }\end{array}$ & $\left(\begin{array}{l}\text { Slightly agree } \\
\text { disagree }\end{array}\right.$ & $\begin{array}{l}\text { Slightly } \\
\text { disagree }\end{array}$ & $\begin{array}{l}\begin{array}{l}\text { Strongly } \\
\text { disagree }\end{array}\end{array}$
\end{tabular}

Comment

3. The Draft Housing Element provides sufficient housing incentives, such as density incentives, expedited design review for small residential projects and financial assistance to promote affordable housing development.

\begin{tabular}{llllll|}
1 & 2 & 3 & 4 & 5 & 6 \\
\hline Strongly agree & $\begin{array}{l}\text { Moderately } \\
\text { agree }\end{array}$ & Slightly agree & $\begin{array}{l}\text { Stightly } \\
\text { disagree }\end{array}$ & $\begin{array}{l}\text { Moderately } \\
\text { disagree }\end{array}$ & $\begin{array}{l}\text { Strongly } \\
\text { disagree }\end{array}$
\end{tabular}

Figure 6. SLO Housing Element survey.

Note. Copied from public handout retrieved September 10, 2009. 
11/19/09 - SLO Climate Action Plan Community Workshop (W8). Testament to growing statewide attention on climate change the City of San Luis Obispo is developing a Climate Action Plan (CAP). The City is working in collaboration with California Polytechnic State University's (Cal Poly) City and Regional Planning Program to develop the CAP. A public workshop was held during the beginning stages of plan development that generated decent attendance from the community. A total of 16 Cal Poly consultants, one staff member, and 13 residents were on hand to discuss action steps for reducing emissions that cause climate change.

One moderator opened the workshop with the declaration that Cal Poly wanted to gather ideas for reducing emissions and find out what participants want the City government to do in terms of climate change. The initial presentation was short as the bulk of the two hour workshop was reserved for discussion tables. Two groups of eight rotated between five activity stations. Each station was organized around a category of emissions (buildings, water, solid waste) or reduction strategy (green community, alternative transit). Two facilitators who asked feedback questions manned tables. Only one station had a design game. Time was split evenly between stations (no breaks), and a satisfaction survey was administered at the end.

Cal Poly relied on numerous visualization tools, including multiple simultaneous PowerPoints, four audiovisual screens, flipcharts, large-scale maps with transparencies, markers, design games (placing symbolic stickers on City 
base map), legends in front of seats with game instructions, preference mapping (put dot next to most important feature of "green" community), residence survey (place smiley face where you live), and posters. Each station was a grouping of two long tables that had a digital projector with a PowerPoint about an issue area. Participants were dispersed during intro, and then asked to form two groups to rotate counter clockwise around stations. Facilitators did nothing when a station was empty.

A refreshment table with coffee, juice, crackers, cheese, and cookies was placed on one side of the room. There was a sign-in table with greeters at the entrance that had nametags for participants. The residence survey was immediately adjacent to the sign-in table with one person directing.

Dialogue was predominately public to consultant. Cal Poly presented a short overview at the beginning, but most dialogue was brainstorming in small focus groups. The public spoke 63 percent of the time versus 33 percent by Cal Poly and 4 percent by City staff. The method of interaction was divided between oratory to listener, small group exercises, and design games.

The meeting was titled "workshop" yet distinctly different from other workshops observed; dialogue was question and answers between participants and facilitators with limited discussion amongst participants. Breakout tables were more like specialized focus groups. Facilitators asked questions like "what can we do" and participants answered while the note-taker recorded on a flip chart. 
Many participants relied on personal stories to illustrate answers. One resident commented on how she liked a recent housing project downtown and is therefore in favor of infill development strategies. Another read a recent story about how solar was successful in a different part of California. Participants needed this step to comprehend issues in their own frame of experience. Some personal accounts were disputed by others at the table. A participant was detailing the recycling process at the local Cold Canyon landfill, and another person refuted his claims. A slight argument occurred, but nothing overtly negative.

One dominator emerged from the group. This person talked louder than everyone else, never raised his hand, and was quick to respond when prompted. He used a lot of personal anecdotes of how he already practices environmentally friendly behavior in his own life. In the beginning it established his credibility, but as the group progressed through activity stations and his comments overpowered discussion, his comments shifted from credible to an air of selfrighteousness.

The design game was confusing to many participants. Initial questions arose about what each symbol means and whether placing one sticker over another meant that priority was given to that particular interest (i.e. placing a local food sticker versus parks and recreation sticker on the base map). Once comprehension was evident among all participants, the design game was successful. The facilitator used a base map for San Luis Obispo but told participants to design their dream city without bias to what already exists. The 
discussion was meant to be more general yet everyone got very specific about neighborhoods and corridors because it hit so close to home. The final product was a map with housing, commercial, services and amenities placed in locations very similar to what exists in San Luis Obispo today. Does this mean that residents are genuinely happy with the SLO's urban design?

Remaining activity stations were focused on generating feedback about an issue. Small group presentations started with factoids and then displayed a discussion question. Face to face interaction between participants occurred when one person could identify with another's answer. Discussion snowballed from one person's response. By the time the group reached Station Three, camaraderie was beginning to form. A few jokes were exchanged and more personal stories amongst group members surfaced.

Questions about factual sources arose at various tables, and some participants had difficult questions for facilitators. Overall, the group was attentive and satisfied with the process. Facilitators always started by thanking people for attending, and participants responded with, "It's nice to be involved in the process"...community ownership!

Children had their own related activities in a separate room: seed planting and coloring books. Judging from the amount of consultants and number of tables, it was apparent that Cal Poly was ready for a larger crowd. Despite extensive outreach efforts, attendance was relatively low. The meeting coincided with a major community activity, which may have deflated attendance numbers. 
It was clear that most participants were already "in the know" at this meeting. Residents without knowledge of environmental behaviors or residents that did not agree with recycling, water conservation, etc., were not represented. For generating ideas on how to reduce emissions, this was not a problem. It is good to rely on resident knowledge. However, the education component of public participation is somewhat lacking when everyone already knows more about the subjects being discussed than the average resident. The presence of a Planning Commissioner in the small group diverted discussion from "what should be done" to "what is the City doing". She was seen as an expert on local government activities and the public wanted to know more about what is happening now. The workshop would have been strengthened if more City employees were present to speak to public interests.

The workshop was appropriately timed because discussion started to break down at the last activity station. Two to three side conversations were observed and the facilitator was having a hard time reigning in the focus of the group. Perhaps people were losing interest in the workshop so it was good to end. However, when time expired one person stated, "Bummer, this is a good discussion!" Throughout the meeting public behavior and body language was positive. Opportunities to participate were plentiful, and the workshop captured significant community input during the data gathering stage of plan development.

Context of case studies. Comparison of case study findings suggests that different participation techniques are necessary for different participation objectives. Techniques designed to elicit genuine participation, such as 
roundtable discussion or design games, were not observed in a quasi-judicial setting where city government officials are deciding whether a project is consistent with adopted policies and standards. Structured windows for public input were not a part of workshops focused on gathering community preferences and desires. Differences between participation techniques and the appropriate venue for using them are further explored in the following interviews with current planners.

\subsection{Interviews}

To evaluate how size of meetings affects participation in practice, interviews were conducted via telephone with key members of planning department staff in larger California cities. All interviewees work in the public sector and have considerable experience with local government workshops and hearings. Responses are italicized and based on the author's interpretation of what was said in interviews. They describe different techniques to engage residents in large cities, including methods targeted at reaching multi-lingual communities. Planner Two believes in most cases public participation makes projects better:

In Sacramento, we have 50 to 60 established community associations or neighborhood groups. Some are long-standing and some form because of one project and stay together. Public participation is achieved through formal neighborhood association's early feedback and is helpful for projects. We route project applications to all affected neighborhood associations. The neighborhood groups send letters or emails back to staff prior to public meetings. They know to engage developers and staff early versus waiting to comment at a public hearing like an average citizen.

Respondents from the three largest cities all remarked that division of the community into neighborhood-based groups is an effective way to engage populous regions. Some cities have designated advisory bodies and councils that 
review projects from specific neighborhoods. According to Planner Three, the City of Los Angeles (L.A.) has Certified Neighborhood Councils. Neighborhood Councils involve all aspects of community, not just homeowners. They look at planning, economic development, and bylaws. It is required that the Neighborhood Council is representative of the community and made up of renters and homeowners. Planner Three notes that this devolves decisionmaking downward. According to Planner Four, San Diego has a similar framework of neighborhood advisory bodies:

Community Planning Groups (CPGs) are advisory bodies to the City on land use issues and specific plan amendments. They are based on geographic areas corresponding to 42 different community plans. CPGs review projects according to policy language in their Community plan. They are an elected body that reviews policy, operating procedures, administrative guidelines monthly, and makes recommendation to City Council. Staff tries to resolve any issues from split votes ahead of time before City Council review.

When asked about the best way to involve large amount of participants to gather representative input, planners from the three southernmost cities responded that languages are a big deal. In San Diego, English and Spanish translators and headsets for translation are a part of the budget. They help facilitate participation and tell the community their input is valued. Planner One felt a recent workshop in Santa Barbara with 200 people, including Spanishspeaking groups, was successful because staff made efforts to reach Spanish speakers. Planner Three indicated that the City of L.A. is multilingual for everything, with bilingual staff, and graphics in two languages. L.A. organizes workshops, hearings, formal and informal meetings, and focus groups in Spanish 
and English. She feels the ethnic divide in L.A. makes it difficult to involve the whole community, especially in poorer neighborhoods:

Mailings don't work for fear of immigration issues. In rich areas mailings are okay. Actually going to churches in African American communities is huge. Nonprofits that have a big presence in the community and good neighborhood standing help organize poorer areas.

The City of L.A. uses nontraditional methods to gather input from a large and diverse community. To involve younger people you need to be web savvy. According to Planner Three, website interactive forums for the L.A. bike plan received over 1,000 comments. Planner Five agrees that online and social media is a growing arena for public networking in SLO. Planner Four relies on human networks to strengthen attendance at participation events in San Diego:

Find a voice in the community that people already trust. Find a church, stakeholder, or other contact to rally the community. Start a stakeholders committee with a key person from each group who attends regular meetings. Keep it moving along to avoid loss of interest.

Planner Two concurs that getting people involved in the diverse city of Sacramento happens through neighborhood groups. It is financially challenging to send a large quantity of notices, so Sacramento planners rely on neighborhood groups to get the message out through email listservs. However, he concedes that it is hard to get a lot of people involved unless there is passion. According to Planner Two, 90 percent of public hearing comments are negative. He notes that if someone likes a project, they are not going to get off the couch at $7 \mathrm{pm}$ and go down to a hearing. Topics have to be worthy of getting a lot of people:

It seems you need a controversial project for people to show up. Some measure of quality of life need be threatened. The Mercy Hospital expansion had so much 
passion on both sides. It is located in an affluent neighborhood and we built a new heart center. It was a billion dollar expansion on the Hospital that filled the Council chambers with a couple hundred people. Video streamed to another room with overflow seating. With lots of added conditions the Council approved it. 80 people at 2 minutes a person spoke. Some organized by topic. Again, it takes a lot of passion. People came out to speak about the positive as a reaction to the negative.

Planner Five also linked challenges with attendance to lack of motivation, because most people have already worked a full day before the hearing. He made the observation that workshops in SLO are always attended by the same old folks and "gadflies". Planner One believes that another format such as a public forum is better for items that generate significant public interest. She described two large forums in Santa Barbara: one on public health and design, and the other an economic study panel. Each had a presentation, panel discussion, and a rotating microphone for questions from audience. Planner One identified a forum as the act of disseminating information with no questions to ask the people. She feels that it is similar to a public hearing, but more comfortable for everyone involved.

Each respondent identified the largest workshop their city had organized and provided details about crowd management. A workshop on the Sacramento Rail Yards private infill project drew attendance of 150 to 200 people. It was broken up into stations: transportation staffed with traffic engineers, land use and historic staffed with members of the Historic Preservation Committee (Personal communication with G. Bitter, 2010). The City of Los Angeles used multiple rooms with stations for transportation, urban design, and land use for workshops that sometimes attracted $500+$ residents. Participants and staff interacted at 
stations in an open house setting. People were more willing to talk in this setting instead of called up to a microphone (Personal communication with $\mathrm{J}$. Blumenfeld, 2010). San Diego's Barrio Logan Community Plan update was a 3 hour public forum held in a warehouse with 75 participants. Each plan element was broken into stations and staff gathered information from people going to each station. It was progressive with no end result other than a compilation of comments (Personal communication with C. Rothman, 2010). The common methodology used is an open house forum with stations staffed by different City departments.

\section{GOING BEYOND A 300-FOOT RADIUS: PUBLIC PARTICIPATION IN THE CITY OF LOS ANGELES}

We used creative methods in South L.A. in a poorer community for a planned transit stop. The consultant, staff and 18 residents took a trip from South L.A. to Portland. Some had never flown in a plane. We rode on every rail, met with officials, neighborhoods, nonprofits and stayed in a nice hotel. All participants were involved in neighborhood groups in L.A. and we made a video for Planning Commission. They got to see things firsthand and were more articulate in their own community. The community took ownership. It took years to convince the bureaucracy because of costs. Some thought you could just show them a picture, but the residents have to experience it. They noticed plants, benches, and other things you wouldn't think about in a picture (Personal communication with J. Blumenfeld, 2010). 


\section{DISCUSSION}

Analysis of case studies identifies effective and ineffective trends among hearings and workshops. Table 4 summarizes pros and cons for each case study observed. In general, hearings attracted larger crowds and stirred emotions more than workshops. They were an effective method for practitioners interested in informing the public about projects being considered by government officials, but lacked opportunities for collaborative dialogue. Workshops on the other hand gave public and planners a chance to communicate back and forth on issues. They were an effective method for practitioners interested in gathering public preference, especially about legislative matters such as plan development or policymaking. Public input often strayed from the purpose of the meeting, which was fine for earlier "brainstorming" stages of planning, but counterproductive in workshops that occurred later in the process when the focus was on plan implementation.

Findings indicate that public participation is influenced by many factors including: attendance and outreach, project scope, formalities, space planning, power roles, group dynamics, the role of the planner, and technology. How practitioners choose to manage these factors determines the outcome of public engagement efforts. The following sections examine these factors in more detail based on case study observations and interviews.

\subsection{Attendance and outreach}

On average, hearings drew better attendance than workshops. The three participation events with the largest audience were all hearings. Top attendance, 


\begin{tabular}{|c|c|c|}
\hline \multicolumn{3}{|c|}{ Comparative summary of case study observations } \\
\hline Key & Effective & Ineffective \\
\hline $\mathrm{H} 1$ & $\begin{array}{l}\text { 1. Staff received direction } \\
\text { 2. Developers clarified project details } \\
\text { 3. Public input before hearing }\end{array}$ & $\begin{array}{l}\text { 1. Residents are attendees not participants } \\
\text { 2. Staff turned their backs to the public } \\
\text { 3. Jargon was formal and alienating }\end{array}$ \\
\hline W1 & $\begin{array}{l}\text { 1. Ample opportunities to participate } \\
\text { 2. Two-way communication } \\
\text { 3. Dynamic use of information }\end{array}$ & $\begin{array}{l}\text { 1. Exorbitant length } \\
\text { 2. Formal Commission response } \\
\text { 3. Lost workshop momentum in hearing phase }\end{array}$ \\
\hline $\mathrm{H} 2$ & $\begin{array}{l}\text { 1. High attendance level } \\
\text { 2. Non-structured ten minute break was } \\
\text { opportunity for public exchange }\end{array}$ & $\begin{array}{l}\text { 1. Opportunities to participate were sparse } \\
\text { 2. No public input on EIR } \\
\text { 3. Staff presentations long }\end{array}$ \\
\hline H3 & $\begin{array}{l}\text { 1. High attendance level } \\
\text { 2. Emotionally charged meeting } \\
\text { 3. Genuine participation afterwards }\end{array}$ & $\begin{array}{l}\text { 1. Informed too late in the process } \\
\text { 2. Seating implied inequalities of power } \\
\text { 3. Public idealism outshined realism }\end{array}$ \\
\hline W2 & $\begin{array}{l}\text { 1. Ample opportunities to participate } \\
\text { 2. Personal stories }=\text { credibility } \\
\text { 3. Meeting was informal }\end{array}$ & $\begin{array}{l}\text { 1. First meeting so trust was not achieved } \\
\text { 2. Skepticism if opinions really mattered } \\
\text { 3. Perception that ideas are not attainable }\end{array}$ \\
\hline W3 & $\begin{array}{l}\text { 1. Two presenters breaks up PPT } \\
\text { 2. Poster stations with staff } \\
\text { 3. Informal mixer afterwards }\end{array}$ & $\begin{array}{l}\text { 1. Presentation was information heavy } \\
\text { 2. Presenter was defensive of public critique } \\
\text { 3. Mayor's presence stifled input }\end{array}$ \\
\hline W4 & $\begin{array}{l}\text { 1. Breadth of attendance } \\
\text { 2. Images softened technical data } \\
\text { 3. Planners "showed their work" }\end{array}$ & $\begin{array}{l}\text { 1. Too many CRP consultants at the meeting } \\
\text { 2. Cohesiveness of focus was lost during } \\
\text { poster session }\end{array}$ \\
\hline W5 & $\begin{array}{l}\text { 1. Face-to-face interaction at tables } \\
\text { 2. Small group presentations } \\
\text { 3. Seats were movable }\end{array}$ & $\begin{array}{l}\text { 1. Dialogue at breakout tables drifted off topic } \\
\text { 2. Statistics/tables did not get message across } \\
\text { 3. Mayor stated no financing for ideas in Plan }\end{array}$ \\
\hline $\mathrm{H} 4$ & $\begin{array}{l}\text { 1. Open to questions throughout } \\
\text { 2. Seeking community validation } \\
\text { 3. Three-dimensional massing model }\end{array}$ & $\begin{array}{l}\text { 1. Exclusively one-way communication } \\
\text { 2. All meetings held in Sr. Center or City Hall } \\
\text { 3. Staff outnumbered community members }\end{array}$ \\
\hline H5 & $\begin{array}{l}\text { 1. Attendance was high } \\
\text { 2. Informed why cuts were being made } \\
\text { and the associated impact }\end{array}$ & $\begin{array}{l}\text { 1. No diversity in the audience } \\
\text { 2. Board constantly looking at their computers } \\
\text { 3. Countdown screen distracting to speakers }\end{array}$ \\
\hline $\mathrm{H} 6$ & $\begin{array}{l}\text { 1. No raised dais } \\
\text { 2. Graphic concepts easy to visualize } \\
\text { 3. Participants were stakeholders }\end{array}$ & $\begin{array}{l}\text { 1. False advertising: hearing not workshop } \\
\text { 2. Chairperson did not keep meeting on track } \\
\text { 3. Council feels compelled to speak up }\end{array}$ \\
\hline W6 & $\begin{array}{l}\text { 1. All who attended participated } \\
\text { 2. Focused group tasks } \\
\text { 3. Small group presentations }\end{array}$ & $\begin{array}{l}\text { 1. Really designed as } \mathrm{CHC} \text { and } \mathrm{ARC} \text { training } \\
\text { 2. Participants were all "in the business" of } \\
\text { historic preservation. }\end{array}$ \\
\hline W7 & $\begin{array}{l}\text { 1. Informative } \\
\text { 2. Opportunity for the public to evaluate } \\
\text { policies }\end{array}$ & $\begin{array}{l}\text { 1. Sparsely attended } \\
\text { 2. Presentation was data heavy } \\
\text { 3. Opinion survey too hard for average person }\end{array}$ \\
\hline W8 & $\begin{array}{l}\text { 1. Ample opportunities to participate } \\
\text { 2. Children had own related activities } \\
\text { 3. Numerous visualization tools }\end{array}$ & $\begin{array}{l}\text { 1. Design game was confusing } \\
\text { 2. A dominator emerged from the group } \\
\text { 3. Limited discussion amongst residents }\end{array}$ \\
\hline
\end{tabular}


including staff and officials, was 75 participants with an average of 44 per hearing. Workshops were smaller public meetings with an average of 28 people involved. The average duration of a participation event was three hours. Figure 7 is a breakdown of attendance for all case studies.

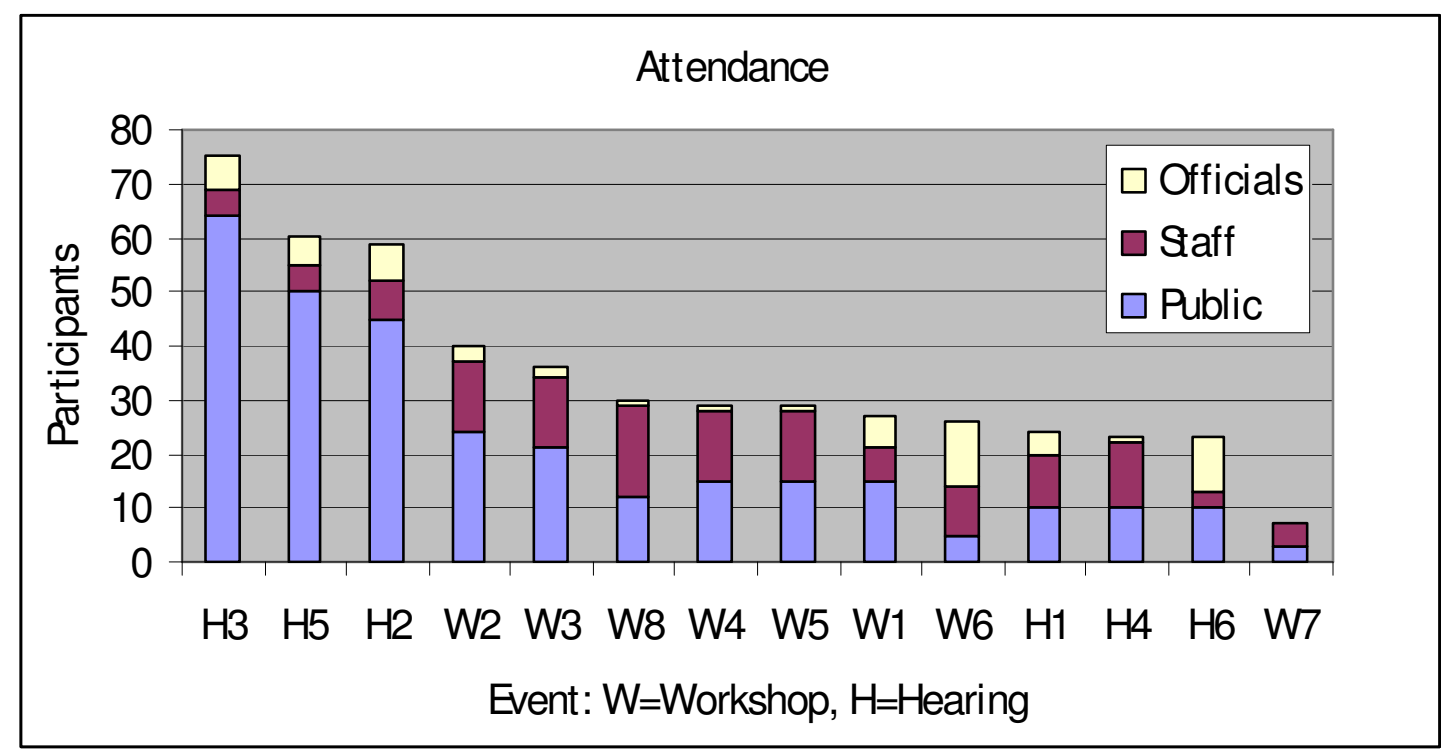

Figure 7. Total attendance by case study

It appears that hearings with high public attendance had fewer staff members present. The staff presence swells amongst workshops, some with a 50/50 ratio of staff to public. Seventy percent of case studies consisted of at least 25 participants.

The three events with highest attendance were hearings focused on controversial issues: paving a portion of parkland, budget cuts, and demolition of historic buildings. People attend more when actions are finite with an immediate impact. Healey (1996) characterizes this reaction as fear of change to local amenities, landscapes and the social mix in neighborhoods. This leads to increasing levels of NIMBY behavior opposing change. 
Workshops were focused on long range actions such as climate action planning or creating a community plan. These topics have a lasting impact that influences everyone, but they are more difficult to express tangibly. Coupled with a long time horizon for implementation, most workshop topics lack closure. It takes investment from community members to spend an evening contributing to visioning exercises and goal-setting. The types of decisions being made at workshops do not have an immediate impact, so residents will often "keep their powder dry" until there is a final and permanent action being taken at a hearing. Despite lower attendance, there were more repeat participants observed at workshops than hearings.

Outreach is a crucial component of both hearings and workshops. Public notification for hearings is typically a four-part process: legal advertisement in a newspaper, a website link, a sign posted at project site, and mailed notices to neighbors. Successful workshops used flyers handed out in-person on streets, in public schools and inserted in city water bills. Sparsely attended workshops seemed to lack these expanded outreach efforts and offered little incentive for participants. Incentivizing participation by offering food, free childcare services, or raffles generates interest and could have bolstered attendance. A major goal of public participation is gathering representative input on planning decisions. Attendance is vital for this goal to be realized.

\subsection{Project scope}

Interviewees indicated that the scope of the project influences the type of participation method used. A common response was that workshops are used for 
city-sponsored projects, such as general plan development, a transit plan centered around a light rail station, or other projects with choices and options. The scope of workshops is far-reaching topics that affect everyone in the whole community. No decision is expected, just discussion of progress, issues, resolutions, and an opportunity to pose questions early in the process. The community at-large is being informed and the officials will make decisions another day.

Hearings frequently focus on private development projects, when the desired outcome is a policy interpretation, entitlement or permit. Hearings occur at the end of a planning process, with other public participation events such as workshops first. They are formulated to get comments about whether people hate a project, love it or want to change it. Interviewees felt that hearings result in a legal decision and must adhere to a legally defined process while workshops are focused on providing information and educating officials and the public.

With the exception of community design projects such as designing a new public playground or community center, the scope of most local government planning projects that incorporate public participation are either policy decisions or quasi-judicial actions. Policymaking has a broad focus that should incorporate public preference on goals and objectives. Workshops enable city government planners to ask appropriate questions of the community to get focused answers on new policy directions or updates. Practitioners have discretion in generating policy alternatives, and therefore look to the community for collaborative decision. However, when a city government acts as a "police power" making a 
determination on a project's compliance with adopted standards, there is limited room for discretion. Public input is constrained to influencing official decisions and reacting to proposed development actions, and findings suggest that a formal hearing is the most effective method for gathering this type of input.

\subsection{Formalities}

There is a code of conduct at public hearings. Parliamentary procedures govern communication and State law requires actions be made by votes on motions. An interview with San Luis Obispo City Attorney Christine Dietrick clarified what formalities are legally required versus locally adopted. Dietrick stated that any standing body is subject to an open meeting, but there is a difference between an open meeting and a public hearing. There are statutory requirements for certain aspects of a hearing, such as making a motion for actions, and making decisions on majority votes. Other meeting procedures follow Robert's Rules of Order, which are locally adopted guidelines consistent with State law. According to Dietrick, Council deliberations are not required, limiting the public to three minute testimony is a local decision, and the Pledge of Allegiance is a personal choice. What is legally required is public notice and the right to be heard. Dietrick describes public hearings as "business meetings" that are not a good forum for engagement. She points to the Brown Act as the driving force behind hearings, and the reason why quasi-judicial bodies must have open meetings to ensure government transparency.

The League of California Cities (2000) identifies two key parts of the intent section of California's Brown Act: 
1. Public commissions, boards and councils and other public agencies in this State exist to aid in the conduct of the people's business. It is the intent of the law that their actions be taken openly and that their deliberations be conducted openly.

2. The people of this State do not yield their sovereignty to the agencies that serve them. The people, in delegating authority, do not give their public servants their right to decide what is good for the people to know and what is not good for them to know. The people insist on remaining informed so that they may retain control over the instruments they have created.

On the surface public hearings meet these goals, but digging deeper reveals potential conflicts with the intent of the Brown Act. Councils are supposed to "aid in the conduct of people's business", yet actions taken in some hearings are the opposite of the majority public sentiment expressed at the time of the decision. Actions must be taken openly, but interviewees responded that a great deal of the work and decisions are made before the hearing begins. The people do not "yield their sovereignty" or give their public servants their "right to decide", yet observations in public hearings suggest that power is in the hands of the commission, board, council or staff. This begs the question of how much an elected official represents its residents. It is difficult to visualize the representative nature of decisions being made at a hearing when public input is clearly subordinate to official deliberations.

\subsection{Space planning}

The physical layout of meeting space influences participation. Chairs, tables, podiums and screens that are setup prior to an event can clue participants in on their roles. Two layouts were predominant among meetings observed: lecture hall and roundtable. Lecture hall setup implies a passive role with attendants as listeners there for intake of information. All chairs, fixed or movable, are usually facing the same direction, with eye contact trained on a speaker or panel of 
officials. A screen at the front of the room can sometimes replace a speaker as the object of interest. Conversely, a roundtable setup informs attendants they are there to be active participants in a small group discussion. Eye contact is directed inward to other members of the small group. This setup empowers individuals to contribute, however contributions can only be heard by other participants at the table. Usually, there is more than one roundtable at a meeting, and conversations happen simultaneously throughout. The lecture hall setup is always one speaker at a time, so that everyone involved can hear what that person has to say.

Degrees of power are implicit in the physical layout of a participation event. When seats are arranged lecture hall style, power rests with the speaker or Council. Public hearings often are lecture hall settings with a raised dais, which

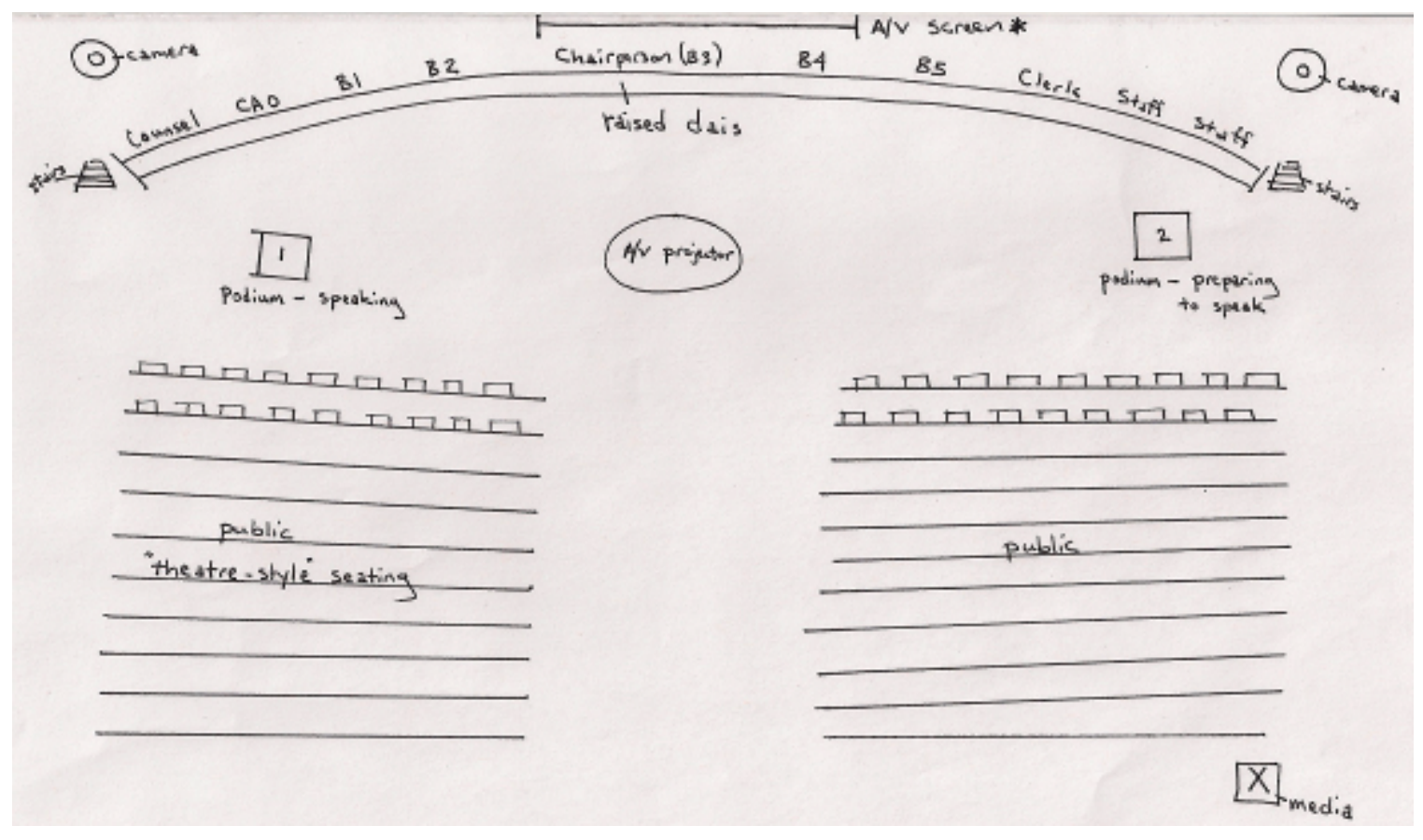

Figure 8. Lecture Hall setup. 
separates the officials from the rest of participants with a physical barrier, and amplifies the relative importance of their role in the hearing, similar to a parliamentary chamber or courtroom. Attention is focused on the moderator or chairperson, who is placed in the center of the dais and charged with managing the proceedings of the meeting. Figure 8 shows how the San Luis Obispo County Board of Supervisors Chambers was set up during 2009 Budget Hearings.

The setting establishes clear boundaries of power with the Chairperson in the center, flanked by the Board, and staff on the wings, of a raised dais. The board and staff interact from a comfortable seated position while community members have to get up from their seats and stand at a podium to participate. Almost all public hearings observed utilized this form of space planning.

The roundtable setup, observed in most public workshops, blurs lines of

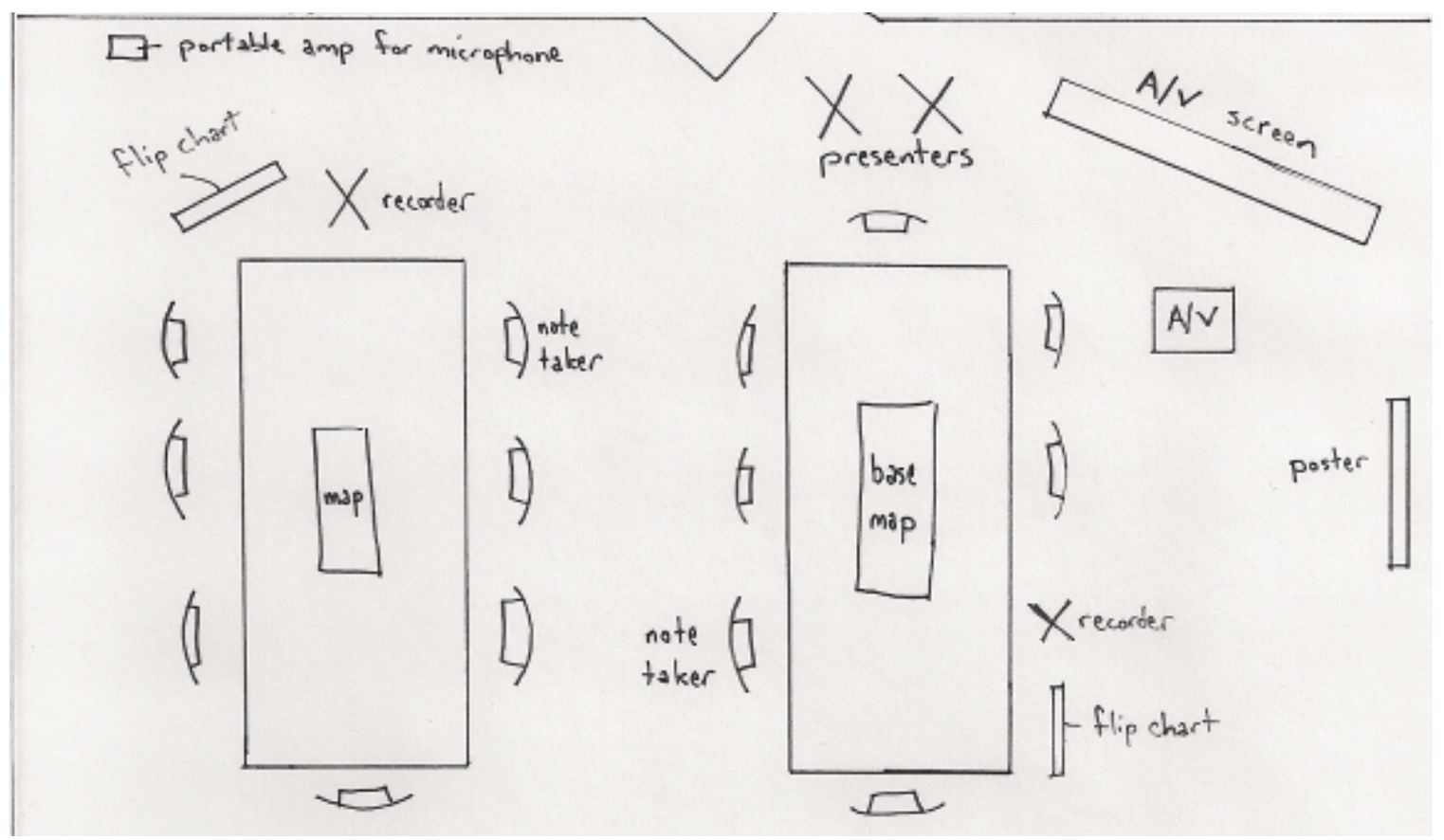

Figure 9. Roundtable setup. 
power. When individuals are seated on the same level around a table, it is difficult to infer where the power lies. Without formal introductions an individual may never know that they were seated next to a Mayor or city official. The focus is no longer centrally-focused on a chairperson because the moderator is integrated into the group. Figure 9 shows the setup of one of the public workshops during the City of Guadalupe's 2008 Visioning meetings. The moderator is noted as "recorder" on the floor plan. Sitting next to a flip chart with marker in hand, the role of the moderator is reversed as compared to the public hearing; information gatherer instead of decision maker. As a result, power shifts to the community member.

It is difficult to cultivate genuine participation in a lecture hall setting. The majority of participants take a passive posture in the seats provided before the participation event even begins. Clear lines of power can be drawn from this type of space planning that suggest authoritarianism instead of cooperation and control by a minority instead of the majority. Roundtable settings break down this hierarchy of roles by seating all on the same playing field, which creates a communal atmosphere.

\subsection{Power}

Division of power begins before the meeting starts based on how space is setup. Varying degrees of responsibility are further defined by speaking roles, authority, personal experience, time limits, and meeting structure.

In a lecture hall setting, whoever is speaking has the power, but it is not absolute. Interruptions from the audience, or more commonly the meeting 
moderator, can shift power in an instant. All observed public hearings had a chairperson who was charged with running the meeting. The chairperson often interrupted members of the public when speaking to ask questions or remind them that their three minute window of time for comment had come to a close. Some moderators even stopped public speakers mid sentence to say their testimony was not relevant. These actions may contribute to overall meeting efficiency, but are counterintuitive to the spirit of participation where all involved should have an opportunity to be heard.

Power roles are more flexible in public workshops because participants speak freely in a less structured format. Dialogue that strayed from the main topic of the participation event went unchecked, especially when individuals were arranged in small groups. Most participants felt compelled to air their grievances about the community or government before getting down to the task at hand. This detracted from the purpose of the meeting. Some small groups avoided this problem with effective moderating. Similar to public hearings, whoever is speaking in a workshop has the power at that moment.

One trend that emerged among all case studies is that power is rooted in control. When a participation event is structured into designated periods for participation, like most public hearings, the participant is powerless until their speaker card is called by the moderator. Control lies with the chairperson instead of the community. This distinction is carried one step further in the power to make decisions. In a public hearing, the community has no authority at the end of the 
Table 5

Public hearing power structure

\begin{tabular}{ll}
\hline Item & Control \\
\hline Introductory remarks & Official \\
\hline $\begin{array}{ll}\text { Public comment about items not on } \\
\text { agenda }\end{array}$ & Residents \\
\hline Presentation about meeting focus & Staff \\
\hline Public comment & Residents \\
\hline Decision-making & Officials \\
\hline
\end{tabular}

meeting when a decision is being made. Table 5 delineates the typical power structure observed in public hearings.

Deshler and Sock (1985) argued that genuine participation is categorized as citizen control, which is an extension of Arnstein's (1969) view of participation as citizen power. Based on this argument, public hearings are not genuine participation since control is essentially removed from citizens. Sanoff (2000) concurs when control of a project rests with administrators it is pseudo participation. Public workshops, on the other hand, shift power from administrator to citizen because emphasis is placed on community viewpoints. Staff typically starts the discussion with focus questions or activities and participants end the meeting with small group presentations or voting. Table 6 delineates the power structure observed at public workshops.

Workshops allow residents to be involved in the resolution of the problem, and hearings limit residents to testimony reacting to proposed solutions. Public 
Table 6

Public workshop power structure

\begin{tabular}{ll}
\hline Item & Control \\
\hline Introductory remarks & Staff \\
\hline Presentation about meeting focus & Staff \\
\hline Discussion or Design Games & Residents (small groups) ${ }^{*}$ \\
\hline Presentations & Residents \\
\hline Resolution (voting on alternatives) & Residents \\
\hline
\end{tabular}

${ }^{*}$ Note. A certain level of control is always afforded to the small group facilitator in workshops, who keeps discussion focused and attempts to involve everyone at the table. This can sometimes prove difficult because of internal power struggles among roundtable participants.

testimony does influence decisions at hearings, but control is still largely in the hands of the Council or administrators. Burns (1979) identified four categories of participation that can be used to illustrate different levels of power observed among case studies:

1. Awareness. Discovering the given environment or situation so that everyone who takes part in the process is speaking the same language.

2. Perception. Moving from awareness to understanding of a situation. People sharing with each other so that objectives of all participants become resources for planning rather than hidden agendas.

3. Decision Making. Participants working from awareness and perception towards a program for the situation.

4. Implementation. People stay involved past the decision making stage and take responsibility with the professionals to see that there are results. 
Public hearings often stop at the perception stage. A hearing gives participants awareness of a situation and the power to share their thoughts about it to increase understanding of all affected parties. Officials may change their decisions based on increased awareness of public sentiment, but the power to make decisions still rests with the governing body. Within the context of workshops, public involvement reaches the decision making stage. Designing alternatives, prioritizing government actions, and voting on potential solutions or programs gives workshop participants the power to be directly involved in decisions. It is important to note however that not all decisions are the same, and the products of workshops are not necessarily "decisions" in the same sense as "actions" taken at hearings. Comparing all decision-making that happens at public hearings to decisions made at workshops based on public desires is a false dichotomy. The intent is to demonstrate what level of involvement the public has on outcomes given the context of the participation event.

Interestingly, all case studies lacked a solid effort to achieve Burns' fourth category of participation: implementation. Perhaps genuine participation could be better achieved in public hearings through strengthened implementation efforts. Organizing a citizen advisory committee to monitor progress of a development project in the field is one example. Or, in cases where the Council's proposed action is contested, ask residents to return to the Council with a superior action plan complete with how, where, when and who, figured out. These steps shift power partially from the Council to the citizenry, keeping people involved and sharing in the responsibility. 


\subsection{Group dynamics}

Wates (2000) contends that "behavior and attitude are just as, if not more, important than methods" in community planning. Hearing and workshops elicit different group dynamics such as behavior and attitude based on meeting structure and roles of participants. For instance, staff and officials speak the most in public hearings. Staff spoke an estimated average of 44 percent of the time during hearings observed, and officials spoke an average of 29 percent of the time. Together this amounts to almost three-fourths of a "public" hearing, with the public speaking an average of 21 percent of the time. Workshops contrast from hearings because there are usually no officials, therefore more time is devoted to public opportunities for speaking. Members of the public were observed speaking an average of 46 percent of the time during workshops. Staff spoke an average of 49 percent of the time, which is statistically similar to hearings. Figure 10 is a comparison of average speaker duration across all cases.
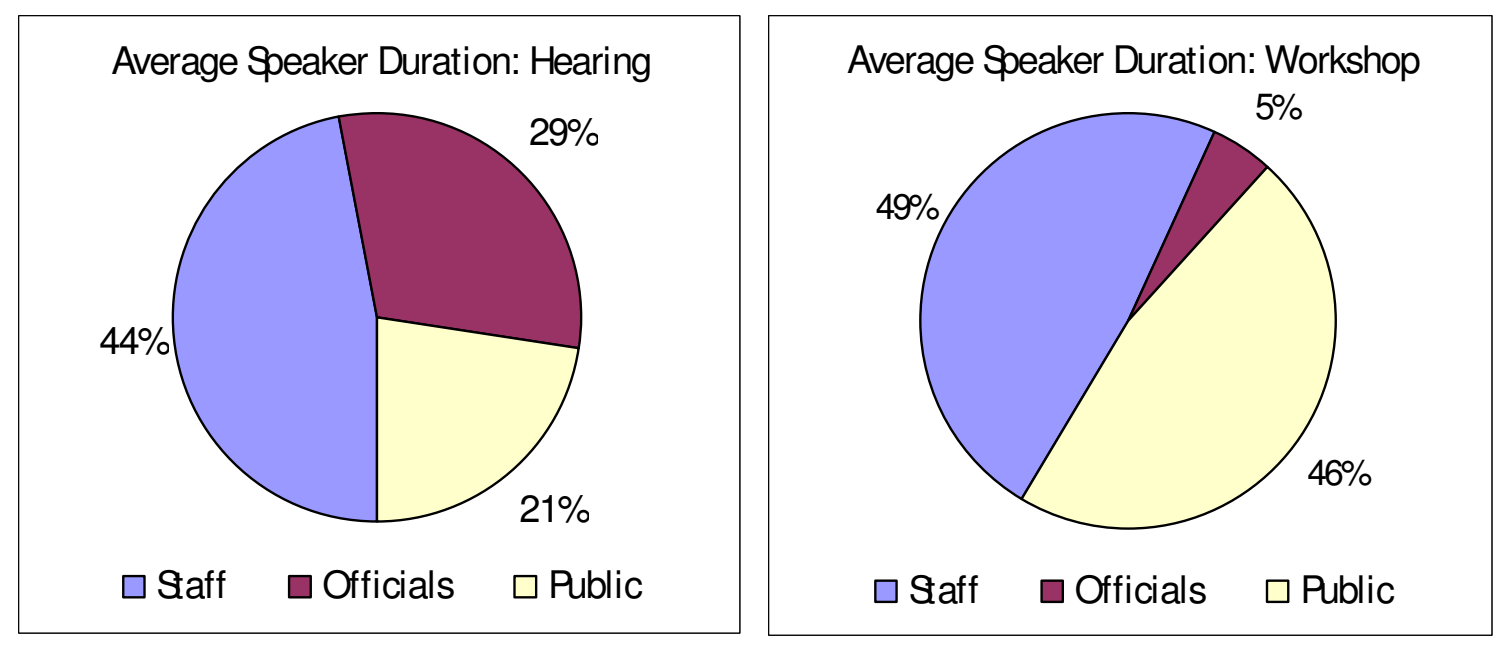

Figure 10. Comparison of average speaking time by participant based on all cases. 
The most effective public meetings observed placed more emphasis on speaking opportunities for residents. Staff comments were limited to introductory remarks or brief informational anecdotes. The least effective meetings were dominated by staff presentations, with limited speaking by the public. Figure 11
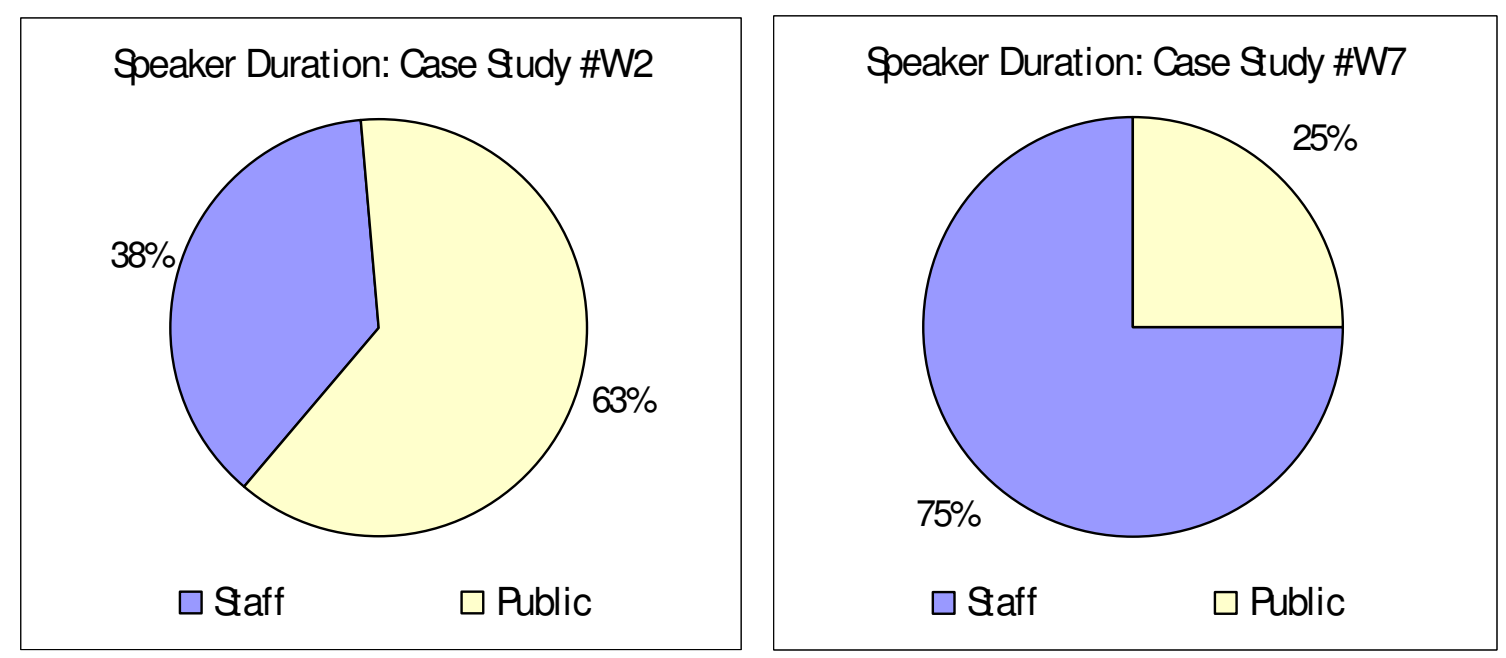

Figure 11. Best and worst cases of speaker duration.

illustrates the best and worst cases of speaker duration. The workshop where the public was documented talking 63 percent of the time (Case Study \#W2) was far more successful than the workshop where staff was documented talking 75 percent of the time (Case Study \#W7).

Varying methods of interaction also account for differences in speaker duration. Most hearings and some workshops followed an oratory to listener format, with the public assuming the role of listener instead of speaker. Wates (2000) suggests that this format is the "consultation" level of community involvement on Arnstein's (1969) ladder of participation, when authorities plan after consulting the community. According to Wates, the crucial level that participation should achieve is "partnership", whereby authorities and community 
members have equal opportunities to speak on an issue as they jointly plan and design.

Enabling opportunities for participants to speak gives rise to the need for effective moderating. One observed benefit of a public hearing is the ability to diffuse difficult participants. Unruly speakers - public and official - are kept in check by the chairperson. Verbose participants are subject to time constraints when speaking. It is difficult for one person to monopolize discussion in a public hearing forum due to firm rules of order. The opposite was observed in many public workshops. A dominator often emerged that spoke at length, was quick to answer questions directed at the entire group, and usually louder than anyone else. A dominator relies on prior knowledge of the subject being discussed and offers numerous personal anecdotes. The act of sharing stories is a common theme among participants in workshops and hearings. Starting a comment with "I've lived here for..." or "I work as a..." adds credibility. In fact, at public hearings it is a requirement to state your name and address before speaking at the podium. In the less-structured workshop environment an individual can go overboard with personal stories and cross the line from credible to self-important. Dominating participants have a deleterious impact on the planner's ability to gather input from less outspoken individuals.

Good facilitation is the key to keeping dominators at bay and allowing other to participate. Splitting a large group into small groups helps reduce the impact of a dominator, and focused group tasks minimizes tangential discussions that distract from the purpose of the meeting. Direct facilitation by the planner or 
group leader is still necessary to rein in overzealous participation from a single individual. Successful workshops and hearings observed were effective because of good facilitators. Local government planning departments and universities should put more emphasis on training planners in facilitation so that managing divergent personalities is possible in public participation events.

\subsection{Planner's role}

Planners assume many different roles in public meetings. The primary responsibility of a planner in a public hearing is support for the decision-making body. Within this supporting role, a planner acts as presenter of a project, technical expert providing knowledge and interpretation of regulations, analyzer offering research and recommendations, and educator. Fulfillment of these responsibilities is dependent upon successful one-way communication from planner to officials. The public is a secondary receiver of information "listening in" on the discourse. According to one interviewee, a planner should direct all comments, including answers to public questions, to the commission only during a public hearing. This standard of protocol can be relaxed if the hearing is a study session.

Workshops elicit some of the same responsibilities as public hearings including: technical expert providing knowledge of good planning principles, presenter of project milestones, educator about government projects and researcher. The major difference in a workshop is that all efforts are targeted at residents. Most workshops observed were designed to educate about current government projects, learn public preference and facilitate community discussion. 
A planner must take on additional roles as facilitator of information exchange, moderator of group discussions, listener and recorder of public feedback. The public becomes active participants instead of a passive audience, and as a result communication flows both ways as planners convey technical information or ask questions to the public, and the public processes the information on their own terms and feeds it back to the planner as desired outcomes.

There is a clear shift in emphasis from planner as technical support in a hearing to planner as facilitator in a workshop. Table 7 revisits Forester's (1993) comparison of instrumental decision-making versus practical communicative action. It is clear that a workshop methodology enables more effective community-based planning derived from "meaningful" participation.

There are other indirect roles that the planner serves related to public participation events. A great deal of analysis, discussion and decision-making occurs prior to a meeting that influences official decisions. The planner also serves as a graphic designer in both hearings and workshops creating PowerPoints, GIS maps, posters and design games. In workshops, the planner is charged with gathering feedback and turning it into goals, objectives, policies and programs. Workshops are usually held in a series, with each subsequent meeting being a refinement of what was generally discussed earlier. The refinement of public desires into policies means the planner acts as translator, taking workshop feedback and blending it with best practices to achieve a designated objective.

The rules of order adhered to in public hearings define roles that limit a planner's ability to interact directly with the public. The job of meeting facilitation 
Table 7

Modified interpretation of Forester's table

\begin{tabular}{cccccc}
\hline INSTRUMENTAL & Hearing Role & TO & $\begin{array}{c}\text { PRACTICAL- } \\
\text { COMMUNICATIVE }\end{array}$ & $\begin{array}{c}\text { Workshop } \\
\text { Role }\end{array}$ \\
\hline informing decisions & Educator & to & $\begin{array}{c}\text { organizing attention to } \\
\text { formulate and clarify } \\
\text { possibilities }\end{array}$ & Educator \\
\hline $\begin{array}{c}\text { reinforcing political } \\
\text { dependency of } \\
\text { affected persons }\end{array}$ & $\begin{array}{c}\text { Technical } \\
\text { Expert }\end{array}$ & to & $\begin{array}{c}\text { Fostering meaningful } \\
\text { political participation and } \\
\text { autonomy }\end{array}$ & Facilitator \\
\hline passing on "solutions" & Analyzer & to & $\begin{array}{c}\text { fostering policy and design } \\
\text { criticism, argument, and } \\
\text { political discourse }\end{array}$ & Moderator \\
\hline
\end{tabular}

* Shaded columns have been overlaid on excerpts from Forester's original table to illustrate the shift in roles as a planner moves from the rational paradigm to communicative action

falls on the chairperson or governing body. Workshops are loosely structured participation events that allow for direct contact with the community. A planner assumes additional roles as facilitator or moderator in the absence of formalities.

\subsection{Technology}

PowerPoint presentation software is everywhere. One hundred percent of public meetings observed included a PowerPoint slideshow. Planning staff relied on PowerPoints to convey information to the community and officials. It is the primary technological method used in local government participation. PowerPoints were successful when the slides contained images, graphs and 3D digital modeling. Slides that were filled with text were difficult to digest. Participant body language was inattentive when faced with numerous slides. PowerPoints were effective at times, but often went on too long. Streamlining content would reduce time planners spent talking at the community in favor of time spent talking with them. 
Other visualization tools commonly utilized in hearings and workshops were posters, handouts, and large-format plans. Occasionally, audience members at hearings brought petitions or blown-up images to aid their testimony at the podium. Planners routinely used flipcharts and markers to record community feedback at workshops. This helped increase transparency of staff actions, and allowed participants to visualize group progress. A screen that displayed the clerk recorder's minutes in real-time to the public may achieve the same result at hearings. The simple act of seeing public testimony entered into the record at a hearing could give participants a small sense of ownership similar to the effect of a recorder and a flip-chart at workshops.

A common thread of participation technology is static use of information. PowerPoints, GIS maps, posters, charrettes and 3D digital models all flow one way from planner to audience. Participants rarely interact with information presented in these methodologies. Some workshops observed incorporated hands-on design games that afforded dynamic information use. Participants modified maps or placed stickers next to draft policies to indicate preference. Pioneering planners are using clicker voting technology or audience response systems to poll participants instantly and display results on an audiovisual screen. Sharman (2008) writes that clickers can be used as an instant poll for debate and as a way of checking how much of the presentation the audience understands. Clickers are hand-held devices that can be given to participants in a hearing, lecture or seminar setting. The presenter asks the audience multiple-choice questions and participants respond by clicking the relevant button on the device. 
Answers are then communicated to the presenter by infra-red transmitter, or radio frequency (Sharman, 2008). It is an effective way to facilitate nonverbal participation.

Computerized tools significantly enhance public participation planning. AlKodmany (2002) notes that, "traditional, noncomputerized tools are not capable of the sophisticated analysis, display, and visualization that may enable the public to make more informed decisions". Al-Kodmany argues that new technologies help make the visioning process more interactive and inclusive. He captures the progression of visualization tools from traditional to computerized/contemporary technology in Figure 12.

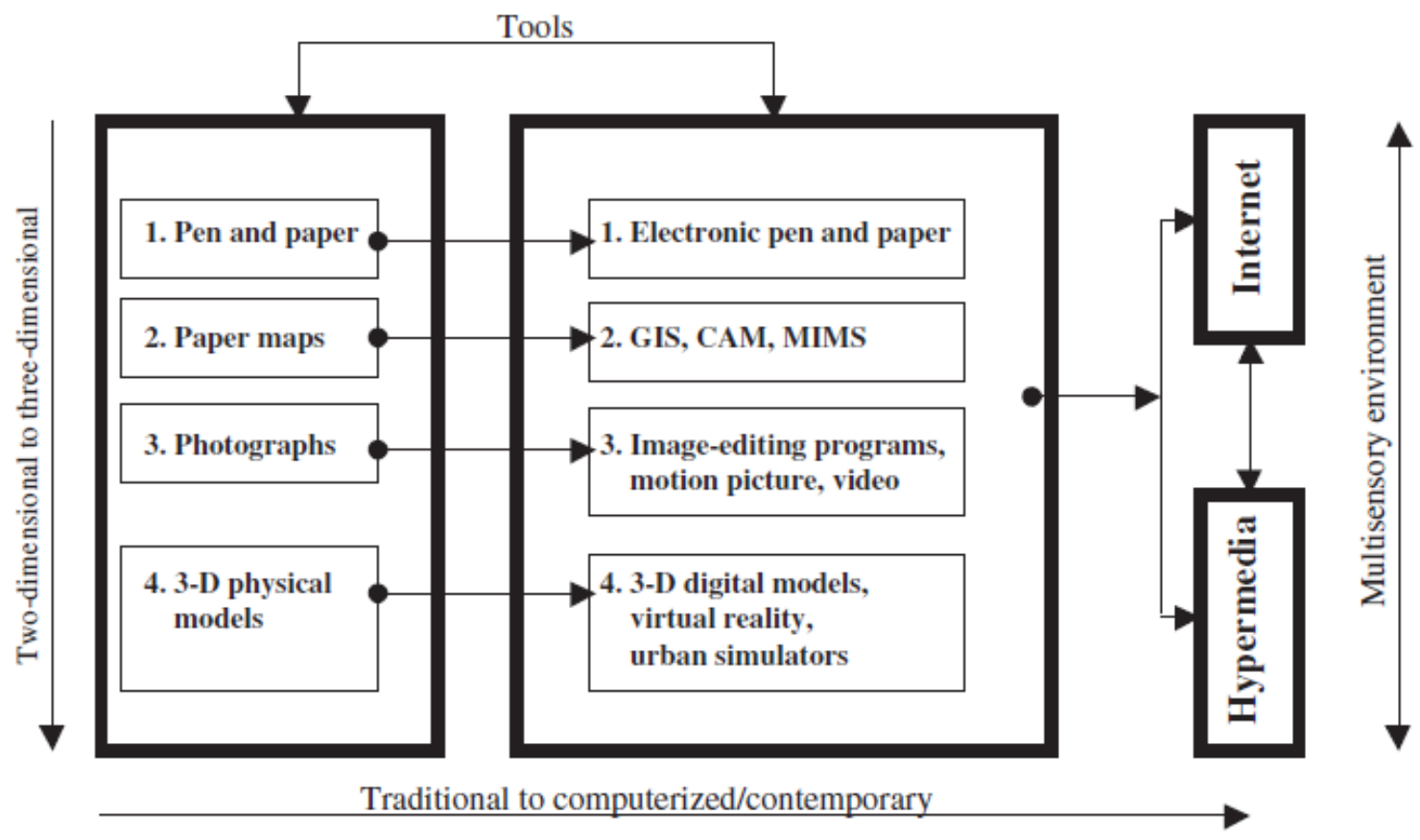

Figure 12. Progression of visualization tools. Adapted from "Visualization tools and methods in community planning," by Kodmany, 2002.

Note. GIS = Geographic Information Systems, CAM = Computer-aided Mapping, MIMS = Mapping Information Management Systems 
The traditional tools identified in Figure 12 are still the crux of most technology used in workshops and hearings. The shift to Al-Kodmany's second set of digital tools was also evident in observed participation events. The two most contemporary visualization methods identified - hypermedia and the Internet - have yet to be realized. The Internet has the power to create a better forum for the free flow of ideas between members of the public and planners. Technology can help minimize time and space problems associated with traditional community workshops, public hearings and static uses of web-based information (Al-Kodmany, 2005). Webinars can reach a vast audience in their own homes and enable real-time polling. A cursory survey of city planning department websites in Central California counties revealed that information is attainable on the web, but there are no interactive web forums. 


\section{CONCLUSIONS AND FUTURE IMPLICATIONS}

Public participation is an essential component of modern planning. Practitioners should seek meaningful public input using different methods throughout the planning process. Analysis of case studies and interviews suggests certain techniques that make participation more effective. These techniques are compiled into a toolkit, presented at the end of this section, which can be used by planners, officials and public for generating a variety of different public participation outcomes.

The toolkit is based on research and firsthand observations of two of the most common forms of public participation in local government planning: hearings and workshops. This study finds that public hearings do not enable effective two-way participation between government and community. Instead, the public hearing elicits one-way communication from decision-makers to community members. Public workshops prove to be a more effective format for genuine public participation in planning.

However, findings indicate that genuine participation is not always the end goal. A large part of local government participation is transparency, and hearings are effective for exposing the community to quasi-judicial decisions and providing limited opportunity for input. In this light, public participation emerges as a check on government power; more reaction and less collaboration.

\subsection{Review of major observations}

Hearings are necessary to fulfill open meeting requirements of the State Legislature. They serve a fundamentally different purpose than a workshop and 
should be the final step in a participation program, but not the only one. Participation methods differ based upon what the project is and who needs to weigh in on it.

Hearings work well for private development projects, to determine things like whether or not the project is exempt from CEQA or if the developer is seeking an entitlement or permit. Workshops would not work on items the agency is considering for action. Workshops are for policy updates, public-private sponsorships, or projects like a new complex or a public park. You need a reason to engage the public that makes sense. It depends on the nature of the project (Personal communication with B. Weiss, 2010).

Current planners define public hearings as information presented and a recommendation on the books, with the majority of work already done and confirmed. Workshops occur on the other end of the participation spectrum and provide opportunity for public input on predominately city-sponsored legislative and design projects.

Observed differences between participation methods are noted in Table 8. The open house method is added to demonstrate how synthesis of attributes from both hearings and workshops can be achieved. Web-based participation is also evaluated since the future of civic engagement, and communication in general, is gravitating towards Internet applications. Different combinations of techniques listed in Table 8 lead to different meeting outcomes. Public participation is shaped by the attendance, physical layout, division of power, structure and technology at a public meeting.

Attendance is often motivated by reaction instead of action. On average, hearings drew better attendance than workshops, and the hearings that were most heavily attended were about controversial projects. It is easier for residents to realize the immediate impact of a new development being reviewed at a 


\section{Table 8}

\section{Distinctions between Participation Methods}

\begin{tabular}{|c|c|c|c|c|}
\hline \multirow[b]{2}{*}{ Technique } & \multicolumn{4}{|c|}{ Public Participation Method } \\
\hline & $\begin{array}{l}\text { Community } \\
\text { workshop }\end{array}$ & Public hearing & Open House & Web-based \\
\hline \multicolumn{5}{|l|}{ Mode of communication } \\
\hline Planner to public & $\mathrm{X}$ & $\mathrm{X}$ & $\mathrm{X}$ & $\mathrm{X}$ \\
\hline Public to public & $\mathrm{X}$ & & & \\
\hline Public to planner & $\mathrm{X}$ & & $\mathrm{X}$ & $\mathrm{X}$ \\
\hline \multicolumn{5}{|l|}{ Duration of speakers } \\
\hline Planner short & $\mathrm{X}$ & & $\mathrm{X}$ & \\
\hline Planner long & & $\mathrm{X}$ & & \\
\hline Public short & $\mathrm{X}$ & $\mathrm{X}$ & $\mathrm{X}$ & \\
\hline \multicolumn{5}{|l|}{ Public long } \\
\hline \multicolumn{5}{|l|}{ Method of interaction } \\
\hline Hands-on & $\mathrm{X}$ & & $\mathrm{X}$ & \\
\hline Digital & & & & $\mathrm{X}$ \\
\hline Oratory/listener & & $\mathrm{X}$ & & \\
\hline Active dialogue & $X$ & & $X$ & \\
\hline Small group exercises & $\mathrm{X}$ & & $\mathrm{X}$ & \\
\hline \multicolumn{5}{|l|}{ Visualization tools } \\
\hline Map & $\mathrm{X}$ & $\mathrm{X}$ & $\mathrm{X}$ & $\mathrm{X}$ \\
\hline Poster & $\mathrm{X}$ & & $\mathrm{X}$ & \\
\hline Digital & & $\mathrm{X}$ & $\mathrm{X}$ & $\mathrm{X}$ \\
\hline Handout & $\mathrm{X}$ & $\mathrm{X}$ & & \\
\hline \multicolumn{5}{|l|}{ Information use } \\
\hline Static & & $\mathrm{X}$ & & \\
\hline Dynamic & $\mathrm{X}$ & & $\mathrm{X}$ & $x$ \\
\hline \multicolumn{5}{|l|}{ Setting } \\
\hline Lecture hall & & $\mathrm{X}$ & & \\
\hline \multicolumn{5}{|l|}{ Conference room } \\
\hline Large meeting room & $\mathrm{X}$ & & $\mathrm{X}$ & \\
\hline Web-based & & & & $\mathrm{X}$ \\
\hline \multicolumn{5}{|l|}{ Structure } \\
\hline Mediated by planner & $\mathrm{X}$ & & & \\
\hline Mediated by officials & & $\mathrm{X}$ & & \\
\hline Free form & & & $\mathrm{X}$ & $\mathrm{X}$ \\
\hline \multicolumn{5}{|l|}{ Stage in planning process } \\
\hline Early & $X$ & & & \\
\hline Middle & & $\mathrm{X}$ & $\mathrm{X}$ & $\mathrm{X}$ \\
\hline Late & & $X$ & & \\
\hline \multicolumn{5}{|l|}{ Public notification method } \\
\hline Media & $\mathrm{X}$ & $\mathrm{X}$ & $\mathrm{X}$ & \\
\hline Internet & $x$ & $\mathrm{X}$ & $\mathrm{X}$ & $\mathrm{X}$ \\
\hline Invitation & $\mathrm{X}$ & & & \\
\hline
\end{tabular}


Table 9

Practicality of scale

\begin{tabular}{|c|c|c|c|c|c|}
\hline \multirow[b]{2}{*}{ Target } & \multicolumn{5}{|c|}{ Public Participation Technique } \\
\hline & $\begin{array}{l}\text { Community } \\
\text { Workshop }\end{array}$ & $\begin{array}{c}\text { Public } \\
\text { Hearing }\end{array}$ & Open House & $\begin{array}{l}\text { Stakeholder/ } \\
\text { Focus Group }\end{array}$ & Web-based \\
\hline Use Permit & & $\mathrm{x}$ & & & \\
\hline $\begin{array}{l}\text { Private } \\
\text { Development }\end{array}$ & & $x$ & & & $\mathrm{x}$ \\
\hline Public Project & $x$ & $x$ & & $x$ & $x$ \\
\hline Specific Plan & $x$ & $x$ & & $x$ & $x$ \\
\hline General Plan & $x$ & $x$ & $x$ & $x$ & $x$ \\
\hline Regional Plan & $x$ & $x$ & $x$ & $x$ & $x$ \\
\hline
\end{tabular}

hearing versus a visioning exercise on far-reaching policies at a workshop. The paradox is that policies crafted at workshops set the standards for eventual development projects, which means attending public workshops will have a more lasting impact on city government decisions than attending hearings.

Selecting a participation method depends on the scale of the project. Genuine participation is not always the end goal for all planning actions. Table 9 summarizes what type of participation events public sector planners engage in relative to project scale. Table 9 indicates that as the scale of a project increases genuine participation opportunities are introduced through workshops and open house forums, however every project needs a hearing regardless of scale. This is inevitable as ideas transition into policy statements or tangible design, because open meetings are required for government land use actions.

The State requires public notice and the right to be heard. The Brown Act requires city governments to have open meetings and maintain transparency 
when making decisions. A hearing is the widely accepted format for those meetings. Robert's Rules of Order are the locally adopted guidelines for running hearings in San Luis Obispo County, and are modeled after parliamentary procedures. Formalities associated with Robert's Rules, such as making formal motions to act on a project or limiting public input to three-minute testimony at a podium, constrain hearings as business meetings instead of genuine participation events.

The physical layout of meeting space influences participation. Workshops rely on a roundtable setup where attendants are face-to-face in a small group discussion. Hearings use a lecture-hall setup with participants in fixed seats facing the same direction focused on a presenter or official body. Roundtable settings enable active participation whereas lecture-hall settings promote passive consumption of information. Power roles are strictly defined in a lecture-hall setup by seating governing officials on a raised dais at the front of the room and requiring residents to stand at a podium to give input. Roundtable settings break down this hierarchy by seating all on the same playing field.

Power is rooted in control. Genuine participation is categorized as citizen control (Deshler and Sock, 1985). In a public hearing, the community has no control at the end of a meeting when a decision is being made. Public testimony can influence decisions at hearings, but control is still largely in the hands of the Council or administrators. Public workshops, on the other hand, shift power from administrator to citizen because emphasis is placed on community viewpoints. 
Workshops allow residents to be involved in decisions, and hearings limit residents to testimony reacting to decisions being made.

Staff speaks the most at public meetings. City planners inform officials and residents using presentations and group facilitation. Speakers at hearings are predominately officials and staff. Workshops provide more opportunities for the public to speak up on an issue. The loosely structured setting elicits personal stories from participants that establish credibility. A dominator can emerge that monopolizes discussion in the absence of a good facilitator or chairperson.

Planners assume many different roles in public participation events. Planners are presenters, technical experts, and analyzers that support a decision-making body in a public hearing. The objective is to help the Council make an informed interpretation of development standards. Workshops require planners to target support to the community as facilitators, moderators, listeners and recorders gathering feedback and turning it into goals, objectives, policies and programs. Public sector planners are educators, in both hearings and workshops, that help the public understand city policies and assist officials in implementation of them in the community.

Most technology in public participation is static use of information. PowerPoints, GIS maps, posters, charrettes and 3D digital models all flow one way from planner to audience. Participants cannot interact with information using this technology. PowerPoint is the most prevalent technological tool at public meetings, which can have mixed results. PowerPoints that contain slides with images, graphs and 3D models are more successful at conveying information 
than PowerPoints that are text heavy or too lengthy. Dynamic use of information, such as design games or other hands-on technologies that enable participants to

manipulate data, prove to be more effective. Audience response systems are a new tool that can poll an audience instantly using clicker response technology. The public can answer a multiple-choice question using a clicker, which gives planners instantaneous feedback and helps gauge audience comprehension. The Internet also provides the same dynamic forum for dialogue between planner and public through webinars and interactive surveys or websites. Technology can reduce barriers associated with time and space making it easier to participate, and increase participation through nonverbal methods.

\subsection{Measuring effectiveness in engaging the public}

Further analysis of case studies indicates how effective different cases were in engaging the public. Effectiveness criteria are identified as: implementation of community ideas, use of mixed media, presentation clarity, behavior/body language, issue resolution, level of active participation, opportunities to participate, diversity and attendance. Figure 13 displays the ratings case studies received for each of these qualitative measures based on a 5-point interval scale. Totaling points received indicates that 7 out of 8 of the most effective cases were workshops.

Since workshops are rated most effective in engaging the public, evaluating what sets workshops apart in Table 8 illustrates necessary criteria for genuine participation: communication amongst participants, limits on staff presentations, small group exercises, multimedia visualization, dynamic information use, 


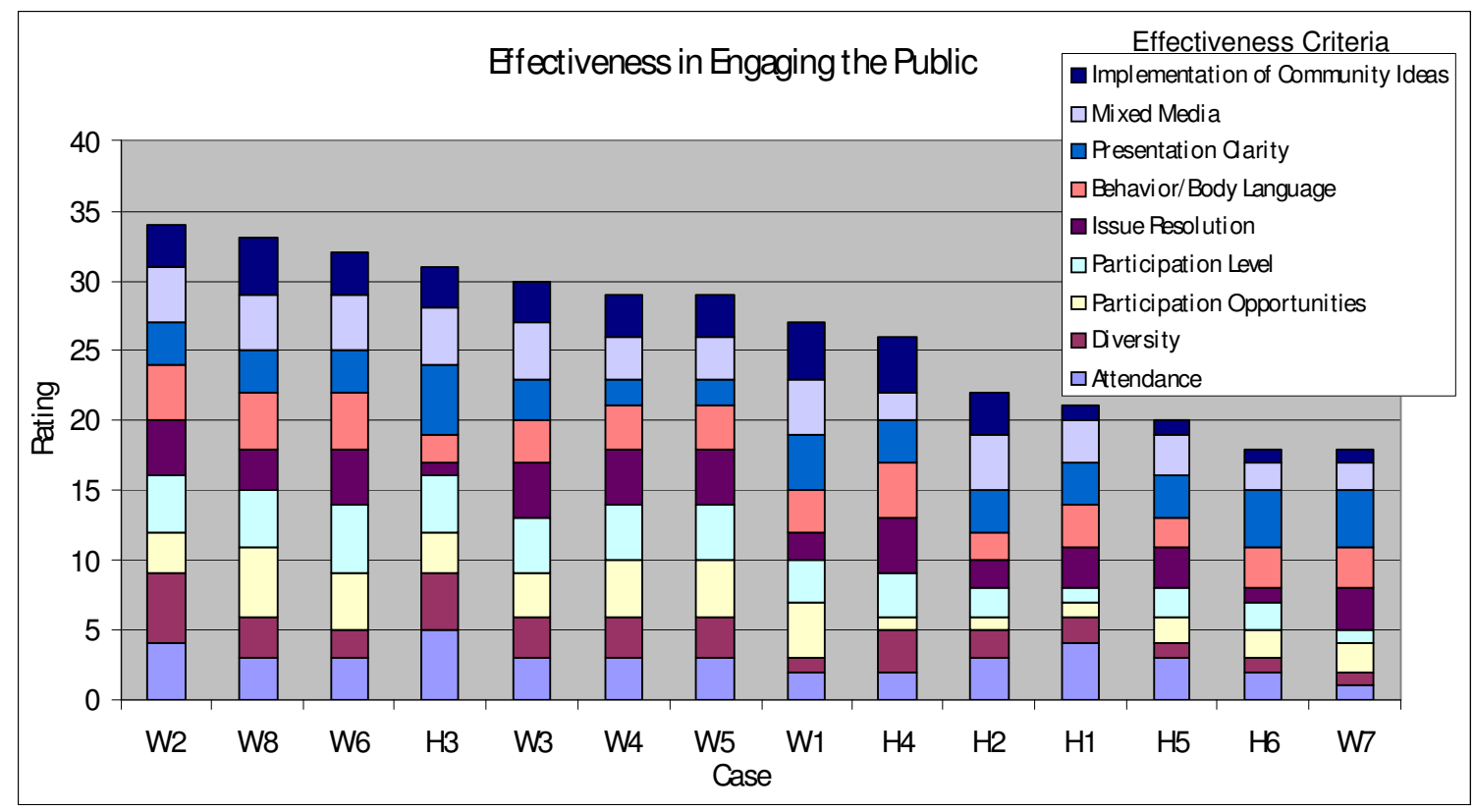

Figure 13. Measuring effectiveness in engaging the public.

settings with ample space, planner as mediator, early engagement, and widespread noticing.

\subsection{A participation toolkit for planning practitioners}

The following recommendations identify techniques practitioners can use to satisfy the aforementioned criteria for achieving effective public involvement. Techniques listed in the toolkit are derived from research and findings presented in this study. The majority of techniques enable genuine participation because focus is placed on involving the community in certain decision-making processes. Partial control is shifted to citizens which results in empowerment. Workshops prove to be the best method for direct public involvement, but they are not ideal for all government planning activity. There are times when citizen control and community-based decisions is not the objective of participation. Quasi-judicial actions by a governing body that happen late in the planning process must be 
Table 10

Determining the type of input needed based on the desired outcome

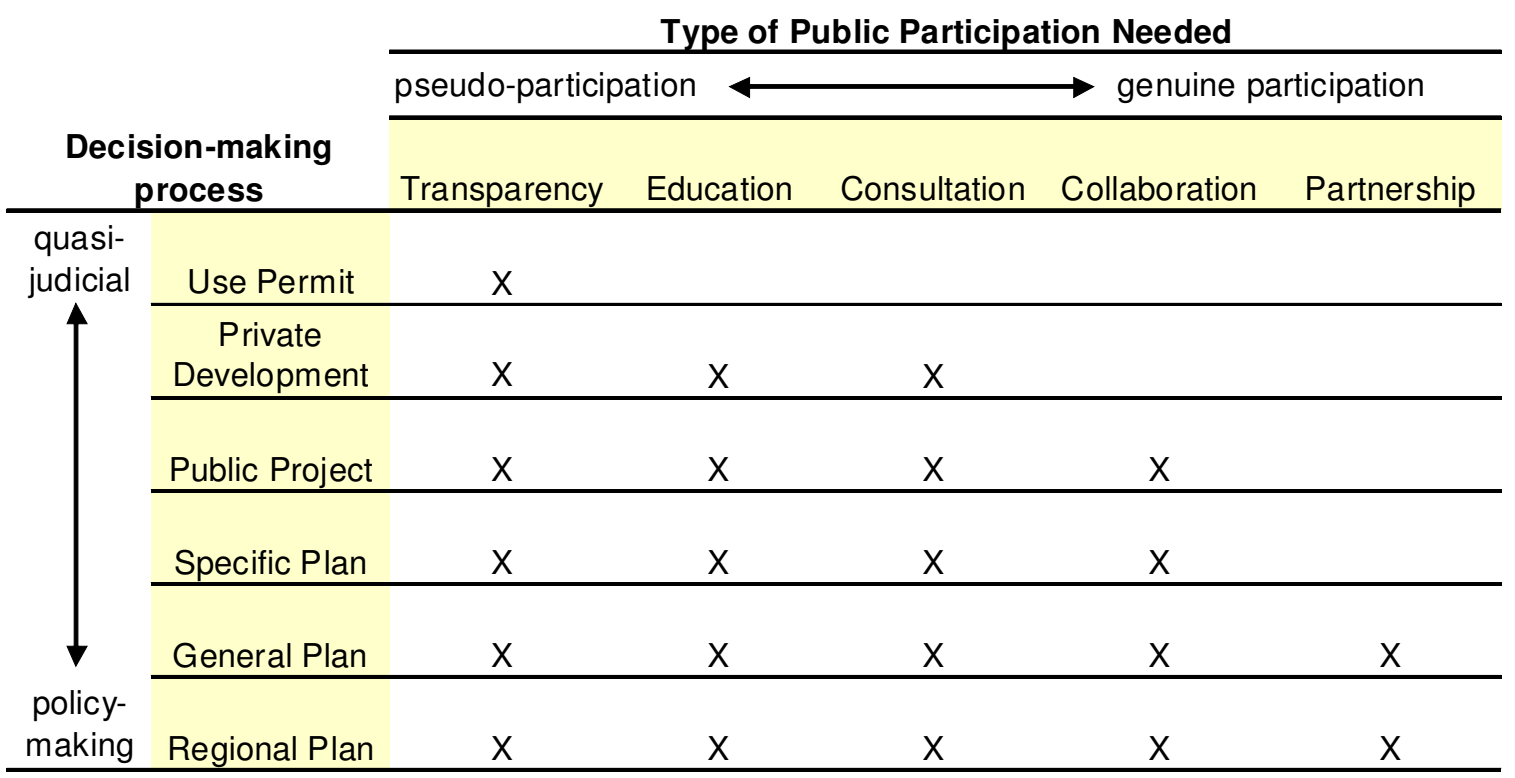

made in an open public meeting, but do not necessitate full public involvement. Hearings prove to be an adequate participation method for these types of planning actions since they function as business meetings instead of public forums.

The key for planners is to correctly diagnose the type of input needed for particular decision-making processes. Table 10 provides a framework for this diagnosis, which is the first step practitioners need to accomplish before identifying which techniques in the toolkit are the best courses of action. Once the type of participation needed is determined, planners and officials can select from techniques listed in the following toolkit to enhance public participation in local government planning. 


\section{A PARTICIPATION TOOLKIT}

Using Table 10, determine the type of public input needed for the decisionmaking process. Then select from techniques listed to enhance participation.

\section{Transparency}

Make projects available for review. Noticing and reporting at every stage maintains transparency, thereby establishing community trust and ensuring compliance with Brown Act.

Improve transparency at hearings. Recording community feedback on flipcharts is a valuable tool for establishing transparency and trust in workshops. A screen that displayed the clerk recorder's minutes in real-time to the public could achieve the same result at hearings and give participants a small sense of ownership.

Call it like you see it. A workshop is people talking face to face in a small group environment without politics. Local government "workshops" often resemble hearings, which is misleading and counterproductive.

\section{Education}

Make it hit home. People participate when there is passion. Most public input is reaction to a project that causes change to their immediate surroundings. Educate residents how long range planning can have the same impact.

Education is just as important as engagement. Community input is more effective when ideas are stirred by an informative presentation. Lay out the planning process and how public input has an effect.

Slideshows should be graphic. Statistics, tables and text heavy slides have the least impact on participants. Concepts such as density and building height do not resonate as well in the absence of tangible images.

Speak the same language. Too much industry jargon can defeat the purpose of an open meeting. The public cannot be involved in planning actions that they do not understand. Auditory cues such as "Madame Chair" are formal and a bit intimidating for participants not familiar with public hearings.

Connect with your audience. Communication between staff and public at hearings is usually filtered through the Council. Presentations are more meaningful when you make eye contact with your listeners.

Alternative forums are better for large groups. An open house with staffed stations addressing key issues is a flexible setting where participants can learn or engage at will. 


\section{Consultation}

Engage the public early in the planning process. Give people an opportunity to review and comment before the public hearing stage.

Update Robert's Rules of Order (first published in 1876). There is a need for a new system of organizing meetings. Alice Cochran (2004) developed a system called Roberta's Rules of Order that encourage open communication, problem solving and effective decision-making, in contrast to Robert's Rules, which advocate formal motions, debate and majority rule.

Limit Council deliberations and staff presentations. Council and staff take up the majority of time at most hearings. Limits will free up time for public input or community discussion, and make meetings more efficient.

Three minute public testimony is a local decision. A municipality can choose how much time is allotted to public comment provided that it is not less than three minutes. Some hearings were more effective when five to ten minutes were allotted for a primary speaker from a specific interest group.

Change the format for public input at hearings. Participants should be allowed to interrupt presentations at appropriate times to ask spontaneous questions similar to a classroom setting. This will enhance efforts to educate the audience and enable the public to be active consumers instead of passive listeners.

Settle it out of court. Most public testimony is pre-prepared at public hearings. Encouraging residents to submit comments online before the hearing gives staff more time to respond and Council the ability to consider public input in a less regulated environment. In an open meeting, Council cannot digress from the noticed intent of a meeting for fear of violating the Brown Act.

Reach out to underrepresented groups. Hearing audiences in San Luis Obispo County are white, middle-aged professionals in suits, ties, and dresses. Going beyond conventional noticing methods will enhance breadth of participation.

Use nonverbal participation methods. Clicker voting technology in the audience or real time voting from viewers at home can be used as an instant poll for decision-makers. It is an effective way to engage participants, and make a hearing an interactive experience.

Expand your audience. The Internet has the power to create a better forum for the free flow of ideas between members of the public and planners. Webinars can reach a vast audience in their own homes and enable real-time polling. 


\section{Collaboration}

Provide comfortable participation opportunities. Public speaking is the number one fear in America. Participants communicate more openly in a casual public setting versus a formal hearing.

Good facilitation skills are a must. Effective moderating incites discussion, prevents dominators, manages diversity and maintains focus. Local government planning departments and universities should put more emphasis on facilitation training.

Planners should wear more hats. Effective participation requires planners to be presenter, technical expert, educator, researcher, recorder, listener, graphic designer, wordsmith, facilitator and moderator.

Work harder on improving attendance. Enable participation through incentives including food and childcare. Expand noticing efforts and vary meeting locations to increase representative input.

\section{Organize workshops that include:}

1. Small Groups to promote direct eye contact among all participants, which can be less confrontational. Make sure you have enough space to breakout into stations or randomly assigned workgroups.

2. Roundtable discussion with ample time at the beginning for participant introductions to establish credibility and unstructured dialogue to air out grievances.

3. Focused tasks starting with what the public likes and moving to improvements. A communal assignment neutralizes preconceived notions associated with class, standing, or power.

4. Mixed media visualization in slideshows, maps, 3D models, handouts, and posters. Include writing implements and encourage participants to get involved in sketching and outlining conceptual feedback.

5. Recording on flipcharts to demonstrate implementation of community ideas.

6. Presentations from each group that give participants a sense of ownership of the meeting.

Know when to stop. Participant interest in PowerPoints begins to wane after an hour. Finish the meeting when momentum is at its highest. 
Move from static to dynamic information use. Hands-on design games and audience response systems (clicker technology) provide instant feedback for debate and gauge audience comprehension.

PowerPoint should remain a visual aid. Streamlining slideshows reduces time planners spend talking at the community in favor of talking with them. Use images and minimal text on a maximum of twenty slides.

\section{Partnership}

Encourage community ownership. Show how public input translates into planning actions. Shift significant control from government to community.

Seek out stakeholders. Involve public with a specific interest and those that will feel an impact. Help people realize when they are a stakeholder.

Multilingualism goes a long way. Make bilingual staff and graphics in two languages part of the budget to facilitate participation and tell the non-English speaking community their input is valued.

Use neighborhood groups in large communities. Find a voice in the community that people already trust. Division of the community into neighborhood-based groups or councils devolves decision-making downward.

The final step is putting the techniques outlined in the toolkit into action.

Figure 14 illustrates how the toolkit can be used to prescribe a participation strategy for a given situation. In this example, a mixed-method participation approach is suggested for a public project, such as a plan for a neighborhood park, that needs community input on goals, objectives and design. A fourmeeting series is proposed that includes an introductory workshop, stakeholder meeting, design workshop, and hearing.

The flow chart illustrated in Figure 14 begins with public outreach and noticing. At the introductory workshop, emphasis is placed on introductions and education. This helps make participants more comfortable with the subject matter and those 


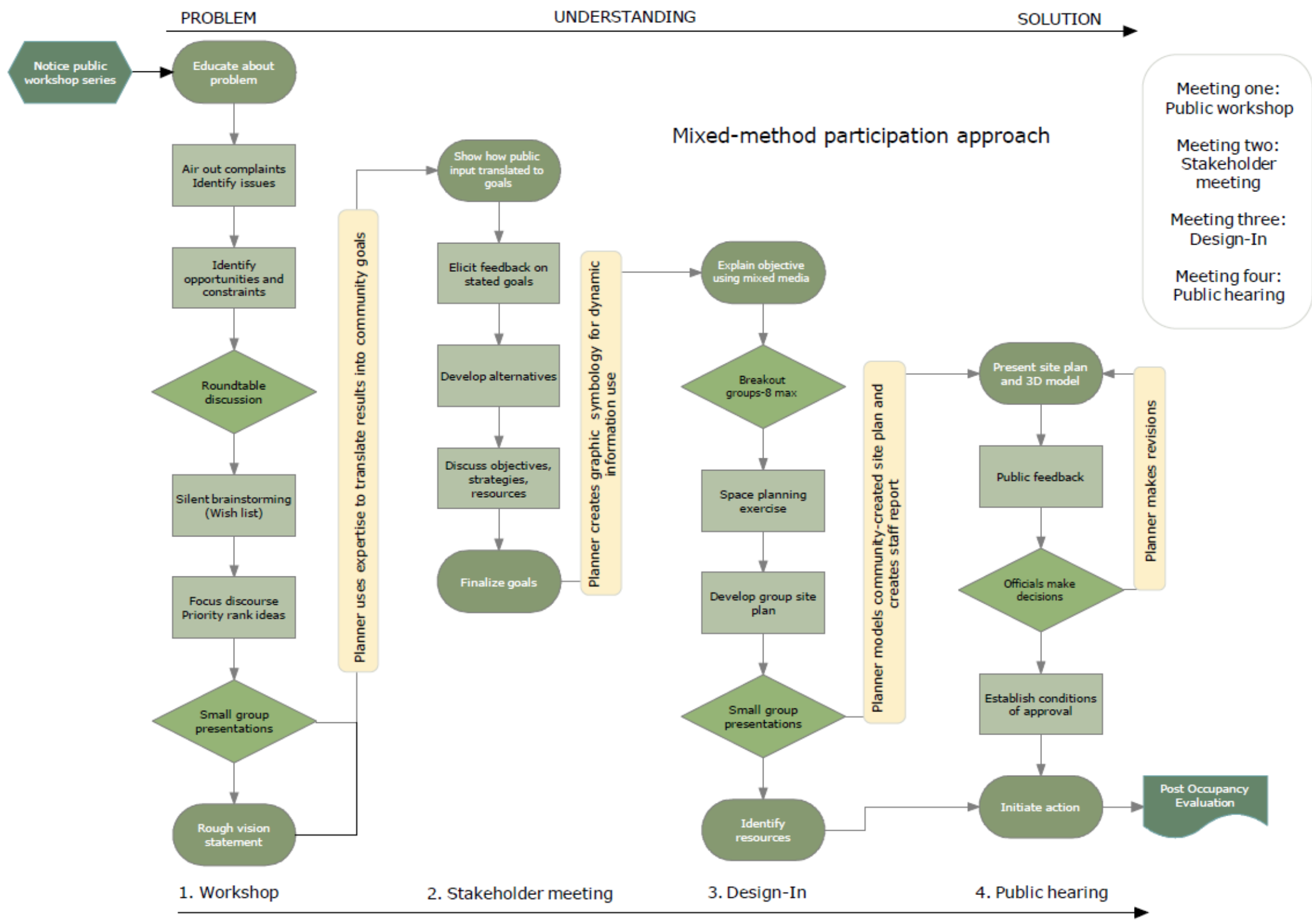

Figure 14. Using the toolkit to inform a mixed-method participation approach for a public project. 
around them, and ultimately works towards establishing trust. Key elements of the initial workshop are: opportunity to air out grievances, focused roundtable discussion facilitated by planners, and small group presentations by a selected resident back to the larger group. Duration of this meeting should not exceed two hours, concluding with a rough vision statement and discussion about next steps. In the time between the first and second public meeting, planners use expertise to translate community feedback into goals. This reiterates the importance of the planner as technical expert, melding sound planning principles with public desires.

The second meeting proposed is a stakeholder meeting made up of key individuals representing different interest groups. Planners begin with a "show your work" exercise explaining how community input from the previous meeting translates into the goals being presented. This ensures transparency and fosters community ownership. Feedback and alternatives are discussed openly, resources are identified, and goals are finalized that set the framework for a plan.

Community identified goals also form the basis for graphic symbology created by the planner for space planning exercises in the third meeting. For example, if residents identified children's play equipment, tennis courts and soccer fields as priorities for a public park, planners can create stickers with symbols representing each item and ask participants to place them in the preferred location on a conceptual site plan. Design games in small breakout groups provide comfortable opportunities for participation and enable residents who prefer nonverbal communication.

The final meeting is a hearing where the end product is presented to officials and residents. Planners adapt community design ideas into a proposed site plan or 3D 
model. A staff report is circulated prior to the meeting that describes goals identified in the participation process, and provides technical analysis of adopted policies or standards. The public is given a last chance for feedback at the hearing, which influences how officials make decisions. Action is initiated by officials, but it is largely up to the community to carry out the post occupancy evaluation by reporting back on whether identified goals were achieved.

The participation strategy illustrated in Figure 14 is one example of how techniques in this study's toolkit can be implemented to enhance public involvement in planmaking and community design. A high level of importance is placed on gathering public input through verbal and nonverbal methods, with the majority of time devoted to speaking opportunities for residents. This will not be effective in all cases, as the level and type of public input needed fluctuates according to the decision-making process. Quasi judicial actions that occur later in the planning process require participation strategies that are more informative than interactive. Nevertheless, all participation techniques presented in this study involve residents as valuable local resources, which leads to more successful community-based and community-owned plans. 


\section{BIBLIOGRAPHY}

Al-Kodmany, K. [2005]. Engaging citizens in public affairs: Online applications. In Evans-Cowley, J. and Conroy, M.M. [Eds.] E-government and Planning. Columbus, Ohio: John Glenn Institute for Public Service and Public Policy, pp. 64-86.

Al-Kodmany, K. [2002]. Visualization tools and methods in community planning: From freehand sketches to virtual reality. Journal of Planning Literature, Vol. 17, No.2, 189211. Retrieved from Ebsco Online keyword "Al-Kodmany".

Al-Kodmany, K. [1999]. Visualization tools and public participation: From crayons to computers. Critical Planning, Spring 1999, 27-35. Retrieved from Ebsco Online keyword "Al-Kodmany".

Arnstein, S. [1969]. A ladder of citizen participation. Journal of the American Institute of Planners, Vol 35, pp. 215-224.

Banfield, Edward. [1959]. Ends and Means in Planning. International Social Science Journal, Vol. XI, No. 3.

Booher, David and J. Innes. [2005]. Reframing Public Participation: Strategies for the $21^{\text {st }}$ Century. Planning Theory and Practice, Vol. 5, Pg. 419-436.

Booher, David and J. Innes. [2010]. Planning with Complexity: An introduction to collaborative rationality for public policy. New York, NY: Routledge.

Brooks, Michael. [2002]. Planning Theory for Practitioners. Washington, DC: Planners Press.

Brown, Ralph M. [1953]. Ralph M. Brown Act. Retrieved on 10/02/2009 from http://www.leginfo.ca.gov/

Burns, J. [1979]. Connections: Ways to Discover and Realize Community Potentials. Stroudsburg, PA: Hutchinson \& Ross.

California. Governor's Office of Planning and Research. [2000]. The Planning and Zoning Law. Sections 65033, 65030 to 65096.

Castells, M. [1999]. The informational city is a dual city: Can it be reversed. In Schon, D. A.; Sanyal, B. and Mitchell, W. J. [Eds.], High Technology and Low-Income Communities. Cambridge, MA: MIT Press.

Cohan v. City of Thousand Oaks, 30 Cal. App. 4th 547, 555 (1994).

Davidoff, P. [1965]. Advocacy and pluralism in planning. Journal of the American Institute of Planners, Vol 31, Pg. 331. 
Deshler, D. and D. Sock. [1985]. Community Development Participation: A Concept Review of the International Literature. Paper presented at the International League for Social Commitment in Adult Education. Sweden.

Forester, John. [1993]. Planning Practice as Communicative Action. In J. Forester, Critical Theory, Public Policy and Planning Practice [pp. 24-29]. Albany: SUNY Press.

Fulton, William [1999]. Guide to California Planning. United States: Solano Press Books.

Healey, Patsy. [1996]. Consensus-building across Difficult Divisions: new approaches to collaborative strategy making. Planning Practice and Research, Vol. 11, No. 2, 207-216.

Hester, R. [1990]. Community design primer. Mendocino, CA: Ridge Time Press.

Innes, Judith E. [1998]. Information in Communicative Planning. Journal of the American Planning Association 64, 52-63.

Kobza, Kim Patrick. [2005]. 10 tips for web-based citizen participation. Retrieved on 04/11/2007 from

http://www.planning.org/thenewplanner/member/2003fall/participation.htm

League of California Cities. [2000]. Open \& Public III: A Guide to the Ralph M. Brown Act. California: League of California Cities.

Nadler, Judy. [2006]. Open Meetings, Open Records, and Transparency in Government. Retrieved on 10/02/2009 from

http://www.scu.edu/ethics/practicing/focusareas/government_ethics.html

O'Kane, Siobhan. [2003]. Public participation in the master planning process. Retrieved on 04/11/2007 from http://www.planning.org/thenewplanner.htm

Sanoff, H. [2000]. Community participation methods in design and planning. New York: Wiley.

Sanoff, H. [1985]. The application of participatory methods in design and evaluation. Design Studies, Vol. 6, No. 4. Retrieved from Academic Elite keyword "Sanoff".

Sharman, Andy. [2008]. A new electronic voting system in lectures is making a real difference. The Independent. Retrieved on 02/24/2010 from

http://www.independent.co.uk/news/education/higher.html

So, Frank et al. [2000]. The Practice of Local Government Planning. Washington, D.C.: International City/County Management Association. 
Talen, E. [1999]. Sense of community and neighborhood form: An assessment of the social doctrine of New Urbanism. Urban Studies, 36[8], 1361-1379. Retrieved from Academic Elite keyword "Talen".

Toker, Z. [2007]. Recent trends in community design: the eminence of participation. Design Studies, Vol 28, pp. 309-323.

Wates, N. [2000]. The Community planning handbook: How people can shape their cities, towns and villages in any part of the world. London: Earthscan.

Wulz, F. [1986]. The concept of participation. Design Studies, Vol 7, No. 3, pp. 153-162.

Yin, Robert. [2003]. Case Study Research: Design and Methods, $3^{\text {rd }}$ edition. United States: Sage Publications, Inc. 


\section{APPENDIX A: Case Study Field Notes}

\begin{tabular}{|c|c|c|c|c|}
\hline Key & Jurisdiction & Method & Location & $\begin{array}{l}\text { Date and } \\
\text { Time }\end{array}$ \\
\hline $\mathrm{H} 1$ & $\begin{array}{l}\text { City of Santa } \\
\text { Maria }\end{array}$ & Hearing & City Council Building & $\begin{array}{l}06 / 07 / 2007 \\
10 \mathrm{am}\end{array}$ \\
\hline W1 & $\begin{array}{l}\text { City of San Luis } \\
\text { Obispo }\end{array}$ & Workshop & City/County Library & $\begin{array}{l}10 / 17 / 2007 \\
5: 30 \mathrm{pm}\end{array}$ \\
\hline $\mathrm{H} 2$ & $\begin{array}{l}\text { City of San Luis } \\
\text { Obispo }\end{array}$ & Hearing & Council Chambers & $\begin{array}{l}11 / 28 / 2007 \\
7 \mathrm{pm}\end{array}$ \\
\hline H3 & $\begin{array}{l}\text { City of San Luis } \\
\text { Obispo }\end{array}$ & Hearing & Council Chambers & $\begin{array}{l}04 / 07 / 2008 \\
5 \mathrm{pm}\end{array}$ \\
\hline W2 & City of Guadalupe & Workshop & $\begin{array}{l}\text { Council Meeting } \\
\text { Room }\end{array}$ & $\begin{array}{l}10 / 23 / 08 \\
6: 30 \mathrm{pm}\end{array}$ \\
\hline W3 & City of Guadalupe & Workshop & $\begin{array}{l}\text { Council Meeting } \\
\text { Room }\end{array}$ & $\begin{array}{l}11 / 20 / 08 \\
6: 30 \mathrm{pm}\end{array}$ \\
\hline W4 & City of Guadalupe & Workshop & Senior Center & $\begin{array}{l}02 / 05 / 09 \\
6: 30 \mathrm{pm}\end{array}$ \\
\hline W5 & City of Guadalupe & Workshop & Senior Center & $\begin{array}{l}02 / 26 / 09 \\
6: 30 \mathrm{pm}\end{array}$ \\
\hline $\mathrm{H} 4$ & City of Guadalupe & Hearing & Senior Center & $\begin{array}{l}03 / 12 / 09 \\
6: 30 \mathrm{pm}\end{array}$ \\
\hline H5 & $\begin{array}{l}\text { San Luis Obispo } \\
\text { County }\end{array}$ & Hearing & $\begin{array}{l}\text { County Government } \\
\text { Offices }\end{array}$ & $\begin{array}{l}06 / 15 / 09 \\
9 \mathrm{am}\end{array}$ \\
\hline $\mathrm{H} 6$ & City of Atascadero & Hearing & $\begin{array}{l}\text { City Hall, Council } \\
\text { Chambers }\end{array}$ & $\begin{array}{l}06 / 16 / 09 \\
7 \mathrm{pm}\end{array}$ \\
\hline W6 & $\begin{array}{l}\text { City of San Luis } \\
\text { Obispo }\end{array}$ & Workshop & City/County Library & $\begin{array}{l}08 / 17 / 2009 \\
08 / 18 / 2009\end{array}$ \\
\hline W7 & $\begin{array}{l}\text { City of San Luis } \\
\text { Obispo }\end{array}$ & Workshop & Community Center & $\begin{array}{l}09 / 10 / 2009 \\
6 \mathrm{pm}\end{array}$ \\
\hline W8 & $\begin{array}{l}\text { City of San Luis } \\
\text { Obispo }\end{array}$ & Workshop & City/County Library & $\begin{array}{l}11 / 19 / 2009 \\
6 \mathrm{pm}\end{array}$ \\
\hline
\end{tabular}




\section{Case Study \#H1}

\begin{tabular}{|c|c|}
\hline \multicolumn{2}{|l|}{ General data } \\
\hline event title & $\begin{array}{l}\text { Study Session: Santa Maria Planning Commission } \\
\text { Open to public }\end{array}$ \\
\hline methodology & Formalized open meeting process (Public Hearing) \\
\hline location & $\begin{array}{l}\text { City of Santa Maria } \\
\text { City Council Building } \\
110 \text { S Pine Street } \\
\text { Santa Maria, CA } 93458\end{array}$ \\
\hline date and time & $\begin{array}{l}06 / 07 / 2007 \\
10: 00 \mathrm{am}\end{array}$ \\
\hline $\begin{array}{l}\text { mediator(s) } \\
\text { (number of } \\
\text { presenters) }\end{array}$ & 5 staff planners \\
\hline event duration & 2 hours and 30 minutes \\
\hline attendance & 10 staff, 4 Commissioners, 10 public \\
\hline early departures & 2 staff, 1 public \\
\hline late arrivals & 2 staff, 3 public \\
\hline weather & 66 degrees, clear \\
\hline members & Planning Commission \\
\hline
\end{tabular}




\begin{tabular}{|c|c|c|}
\hline \multicolumn{3}{|c|}{ Meeting Characteristics } \\
\hline $\begin{array}{l}\text { purpose/focus of } \\
\text { meeting }\end{array}$ & \multicolumn{2}{|c|}{ Review of Planning department current project list } \\
\hline $\begin{array}{l}\text { level of dialogue } \\
\text { staff to public } \\
\text { public to public }\end{array}$ & \multicolumn{2}{|l|}{ Primarily staff to Commission } \\
\hline $\begin{array}{l}\text { speaker duration } \\
\text { staff vs. public }\end{array}$ & $\begin{array}{l}\text { 1. Public }(10 \mathrm{~min}) \\
\text { 2. Staff }(80 \mathrm{~min}) \\
\text { 3. Commissioners }(60 \mathrm{~min})\end{array}$ & $\begin{array}{l}\text { Staff: } 53 \% \\
\text { Commission: } 40 \% \\
\text { Public: } 7 \%\end{array}$ \\
\hline $\begin{array}{l}\text { visualization tools } \\
\text { maps, posters, } \\
\text { digital, } \\
\text { pamphlet } \\
\end{array}$ & \multicolumn{2}{|c|}{$\begin{array}{l}\text { PPT, audiovisual screen, zoning map poster, TV, agenda, project } \\
\text { specific documents (sections, aerials, site plan), Photo Mapper } 4.23 \text {. }\end{array}$} \\
\hline structure & \multicolumn{2}{|c|}{$\begin{array}{l}\text { Begins with public comment period for items not on the agenda. } \\
\text { Typical hearing style with each agenda item taken in turn. Different } \\
\text { planners presented each item and responded to questions from the } \\
\text { Commission. Meeting was conducted at a frenzied pace, which } \\
\text { created stress. }\end{array}$} \\
\hline setting & \multicolumn{2}{|c|}{$\begin{array}{l}\text { Conference room with approximately } 35 \text { seats. Commission and staff } \\
\text { were seated at an L-shaped table up front, while public seats were } \\
\text { relegated to the back of the room. Staff had their backs to the general } \\
\text { public. } \\
\text { Space was too cramped for the amount of attendees. Significant traffic } \\
\text { in and out from staff members and various side conversations were } \\
\text { distracting. }\end{array}$} \\
\hline $\begin{array}{l}\text { stage in planning } \\
\text { process } \\
\left(1^{\text {st }}, 2^{\text {nd }}, 3^{\text {rd }}\right. \\
\text { meeting }) \\
\end{array}$ & \multicolumn{2}{|c|}{$\begin{array}{l}\text { Initial look at projects prior to regularly scheduled Planning } \\
\text { Commission meeting on } 06 / 20 / 07 \text {. No motions or actions took place. }\end{array}$} \\
\hline $\begin{array}{l}\text { method of } \\
\text { interaction }\end{array}$ & \multicolumn{2}{|c|}{$\begin{array}{l}\text { Oratory/listener, active dialogue between staff and Commission. } \\
\text { Public role is peripheral at best (information gathering). }\end{array}$} \\
\hline $\begin{array}{l}\text { public notification } \\
\text { method }\end{array}$ & \multicolumn{2}{|l|}{ Legal ads, local newspaper } \\
\hline
\end{tabular}




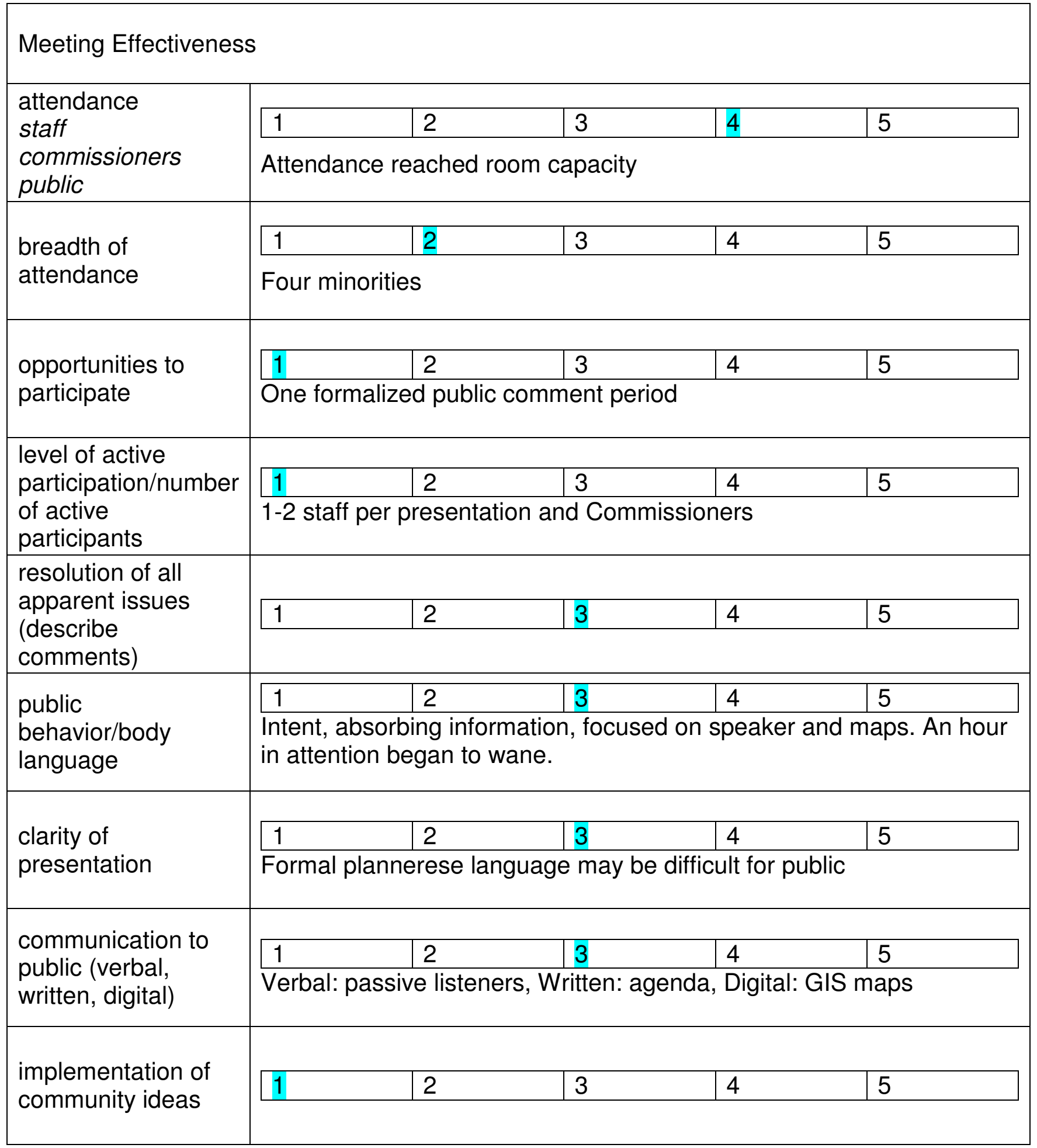




\section{Further Observations}

"Madame Chair" or "Members of the Commission" was heard at the outset, which set the formal tone of the meeting.

Door remains open for public to come and go in the beginning, but then is closed 30 minutes into the meeting.

Public comments were mainly from representatives of the development community (Rite Aid). Staff and representatives provided detailed descriptions of project design features.

Most projects are already in progress. The hearing elicited limited (if any) public input on actual changes to the projects. Public was not allowed to comment as presentations proceeded.

Commissioners glossed over public comment, attributing an air of unimportance. Commissioners were more concerned with asking questions of staff.

Language was so formalized and a bit alienating. Using too much industry jargon can defeat the purpose of government transparency.

Staff members leave when discussion about their project is over. Public departs when items of interest have been heard. At the end of two and a half hours only six participants remained ( 2 of which were late arrivals). 


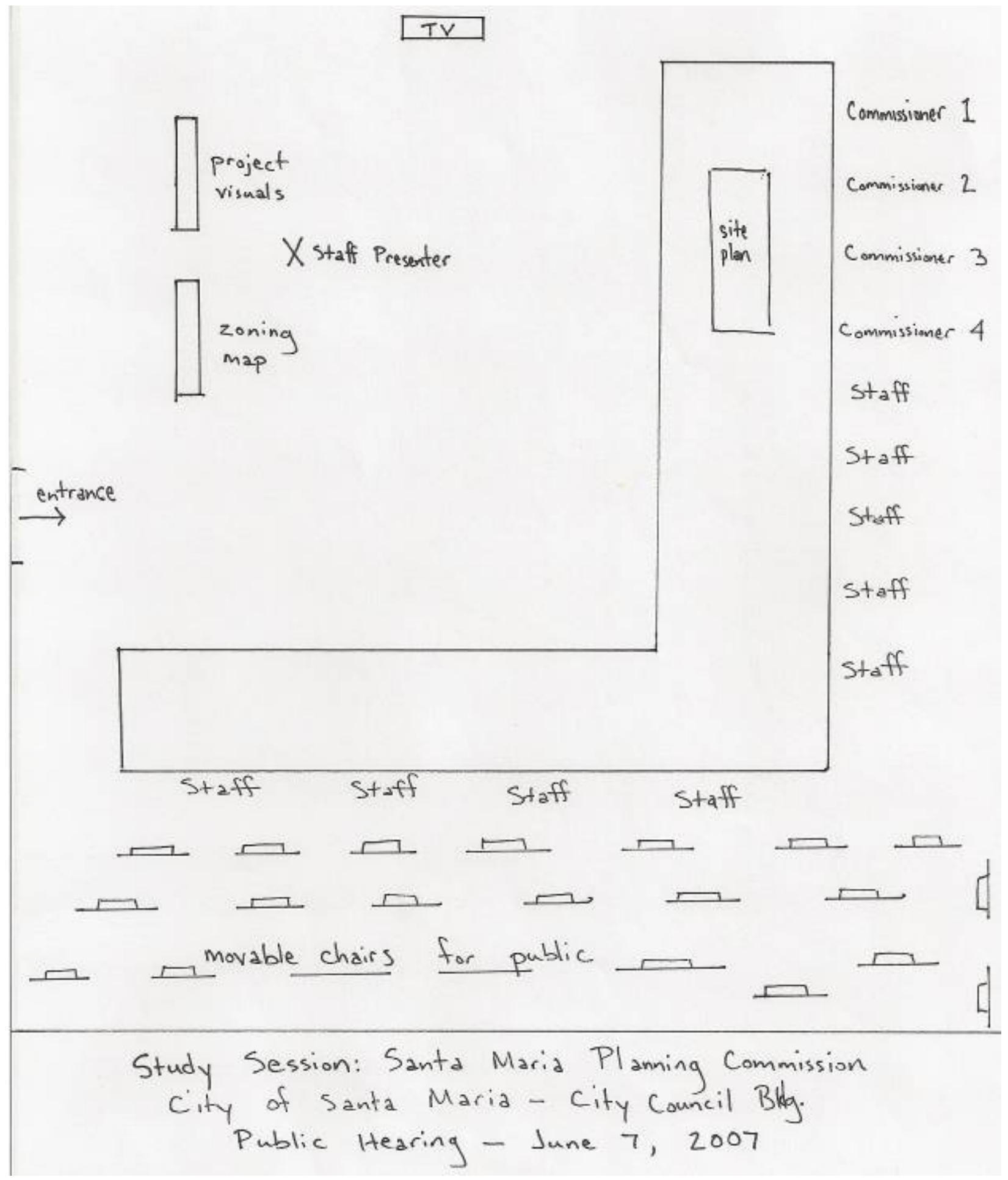




\section{Case Study \#W1}

\begin{tabular}{|c|c|}
\hline \multicolumn{2}{|l|}{ General data } \\
\hline event title & $\begin{array}{l}\text { San Luis Obispo Planning Commission } \\
\text { Special Workshop } \\
\text { South Broad Street Corridor Plan }\end{array}$ \\
\hline methodology & Mixture of hearing and workshop \\
\hline location & $\begin{array}{l}\text { City County Library } \\
\text { Community Room - } 995 \text { Palm } \\
\text { San Luis Obispo, CA } 93401\end{array}$ \\
\hline date and time & $\begin{array}{l}10 / 17 / 2007 \\
5: 30 \mathrm{pm}\end{array}$ \\
\hline $\begin{array}{l}\text { mediator(s) } \\
\text { (number of } \\
\text { presenters) }\end{array}$ & $\begin{array}{l}\text { Jeff Hook, project planner } \\
\text { Kim Murry, supervisor }\end{array}$ \\
\hline event duration & 4 hours and 15 minutes \\
\hline attendance & $\begin{array}{l}15 \text { gallery } \\
6 \text { commissioners } \\
6 \text { staff }\end{array}$ \\
\hline early departures & $15 \%$ early, $40 \%$ after breakout session \\
\hline late arrivals & 5 public \\
\hline weather & 60 degrees, slight chill \\
\hline members & $\begin{array}{l}\text { Commission: Dan Carpenter, Michael Multari, John Ashbaugh, } \\
\text { Amanda Brodie, Diana Gould-Wells, Charles Stevenson and Carlyn } \\
\text { Christianson }\end{array}$ \\
\hline
\end{tabular}




\begin{tabular}{|c|c|c|}
\hline $\begin{array}{l}\text { purpose/focus of } \\
\text { meeting }\end{array}$ & \multicolumn{2}{|c|}{$\begin{array}{l}\text { Public and Planning Commission input on latest draft of South Broad } \\
\text { Street Corridor Plan. Emphasis placed on three broad areas: land } \\
\text { use, circulation and form-based codes (FBC). }\end{array}$} \\
\hline $\begin{array}{l}\text { level of dialogue } \\
\text { staff to public } \\
\text { public to public }\end{array}$ & \multicolumn{2}{|c|}{$\begin{array}{l}\text { PPT predominantly staff to Commission, public = observers } \\
\text { Non-agenda public comment = one person, cut off by Chair } \\
\text { Meeting most successful when Commissioners and public sat around } \\
\text { tables talking to one another about implications of form-based codes } \\
\text { in the South Broad Street planning area }\end{array}$} \\
\hline $\begin{array}{l}\text { speaker duration } \\
\text { staff vs. public }\end{array}$ & $\begin{array}{l}\text { 1. Commission (past agenda review) }-25 \\
\text { min } \\
\text { 2. Public comment (non-agenda) }-10 \text { min } \\
\text { 3. Staff }-1 \text { hour } \\
\text { 4. Breakout groups }-1 \text { hour } \\
\text { 5. Group presentations }-30 \text { min } \\
\text { 6. Commission (deliberations) }-1 \text { hour }\end{array}$ & $\begin{array}{l}\text { Commission }= \\
35 \% \\
\text { Staff }=30 \% \\
\text { Public }=35 \%\end{array}$ \\
\hline $\begin{array}{l}\text { visualization tools } \\
\text { maps, posters, } \\
\text { digital, } \\
\text { pamphlet }\end{array}$ & \multicolumn{2}{|c|}{$\begin{array}{l}\text { PPT: text, maps, tables, 3D Sketchup massing models } \\
3 \text { handouts: PPT slides, staff report, specific plan (1 per table) } \\
\text { Large-scale conceptual area maps, successful FBCs from other cities } \\
\text { Flipcharts, markers, pencils, highlighters }\end{array}$} \\
\hline structure & \multicolumn{2}{|c|}{$\begin{array}{l}\text { Began with formal meeting } \\
\text { Transitioned to workshop with breakout groups } \\
\text { Breakout table: } 2 \text { Commissioners, } 1 \text { facilitator, } 1 \text { recorder, 5-7 general } \\
\text { public } \\
\text { Returned to formal deliberations after workshop }\end{array}$} \\
\hline setting & \multicolumn{2}{|c|}{$\begin{array}{l}\text { Lecture hall setting in Public library with movable chairs and tables. } \\
\text { Good multi-use setup. Stage with drop-down screen for presentations. }\end{array}$} \\
\hline $\begin{array}{l}\text { stage in planning } \\
\text { process } \\
\left(1^{\text {st }}, 2^{\text {nd }}, 3^{\text {rd }}\right. \\
\text { meeting })\end{array}$ & \multicolumn{2}{|c|}{$\begin{array}{l}\text { Working draft plan, consultant input, conceptual land use map. Still } \\
\text { relatively early in process, fourth in a series of Commission meetings. } \\
\text { Project began in early } 2006 \text {. }\end{array}$} \\
\hline $\begin{array}{l}\text { method of } \\
\text { interaction }\end{array}$ & \multicolumn{2}{|c|}{$\begin{array}{l}\text { Early stages of meeting: Oratory/listener } \\
\text { Workshop phase: Hands-on drawing on large area maps, active } \\
\text { dialogue among small groups }\end{array}$} \\
\hline $\begin{array}{l}\text { public notification } \\
\text { method }\end{array}$ & \multicolumn{2}{|l|}{ sign postings, newspaper, City website } \\
\hline
\end{tabular}




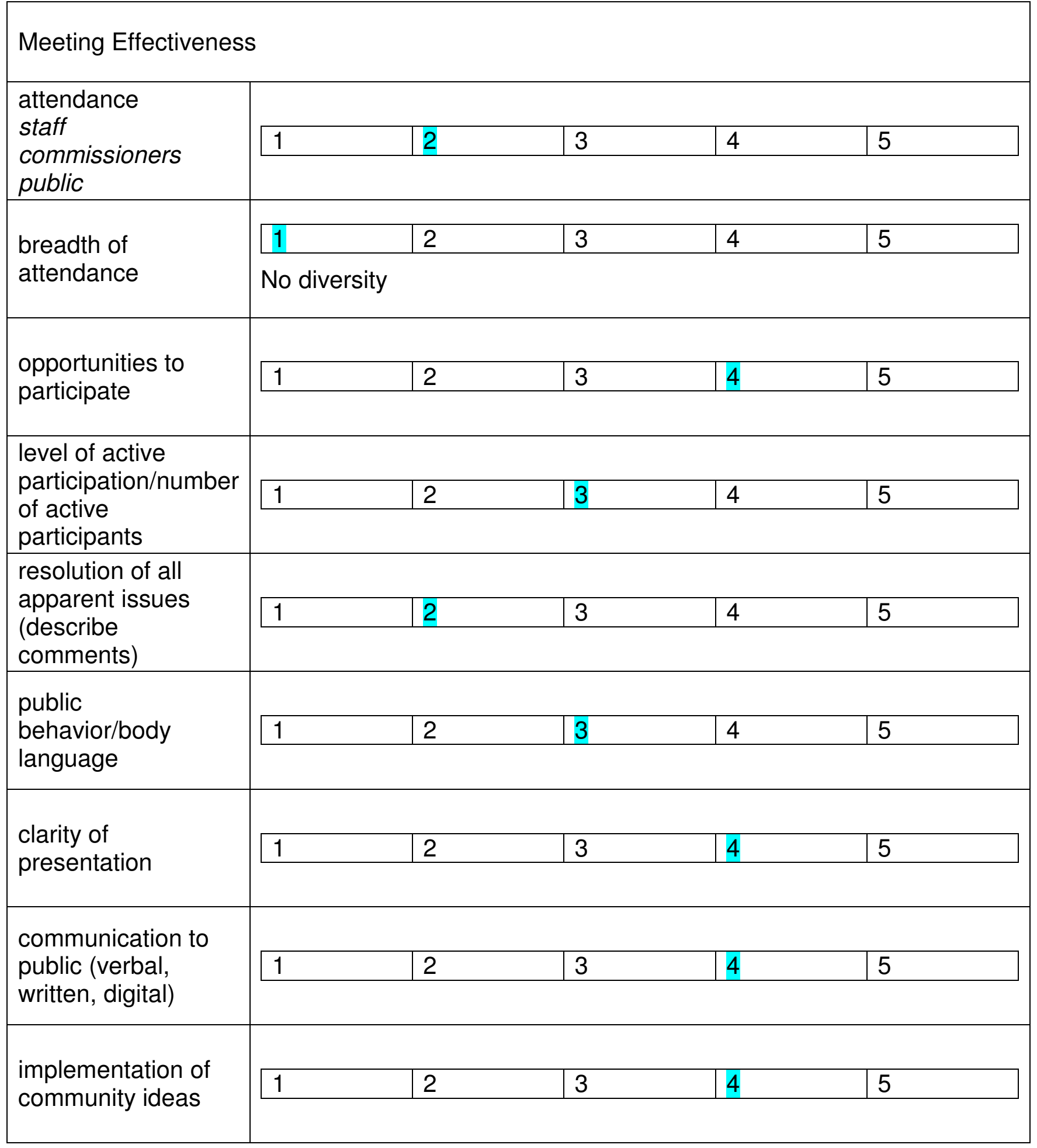


Further Observations

The opening discussion of the group was about the value of FBCs. It was a heated discourse and the facilitator did not intervene. Talking points were outlined at the beginning but the group did not adhere to them.

Each group member established credibility early (i.e. professional planning experience, staff, SLO resident duration and proximity to development action). This was additional unsolicited information that was volunteered by each participant.

The first half of breakout time was dominated by argument between one Planning Commissioner and other group members. After all parties had aired out their grievances and complaints, consensus-building could begin. The facilitator recognized the quiet person in group, and he got to speak his mind which empowered his participation that was otherwise nonexistent up until this point. The most vocal participants were the commissioners, developer and affected resident.

The group agreed that FBCs were only appropriate for developing the "Main St" in the mixed-use core. Other generated group goals were general opinions on land use in the Broad St area. Most talking points were not addressed.

Rotating staff sat in at times to help steer the group back to the objective of identifying outcomes for the specific area. The facilitator was hands-off most of the time.

Recordation of group goals was on flipcharts at the last minute. General bullet points were created that encompassed agreed upon group feedback. At the end, the most vocal Planning Commissioner presented group results to all workshop participants.

Breakout Group Dynamics. Groups were given talking points to address and report back on in 45 minutes. Opening discussion about value of FBCs is heated discourse. Facilitator did not intervene. Each group member established credibility early (i.e. professional planning experience, staff, SLO resident duration and proximity to development action). This was additional unsolicited information that was volunteered by each participant. First half of breakout time dominated by argument over drawbacks and benefits of FBCs. After all parties had aired out their grievances and complaints, consensus-building could begin. Facilitator recognized quiet person in group, he got to say his peace which empowered his participation that was otherwise nonexistent up until this point. Most vocal: Commissioner, developer and affected resident. Group agreed that FBCs only appropriate for "Main St" in the mixed-use core. Other group goals were general opinions on land use in the Broad St area. Most talking points not addressed. Rotating staff sat in at times to help steer group back to objective: The overall goal is to identify which outcomes we want for the specific area. Facilitator was hands-off most of the time. Discussion point: hands off vs. proactive facilitation in a small group. Recordation on flipcharts was at last minute; broad bullet points that encompassed agreed upon group feedback. Group member who was Commissioner presented results to all workshop participants. 


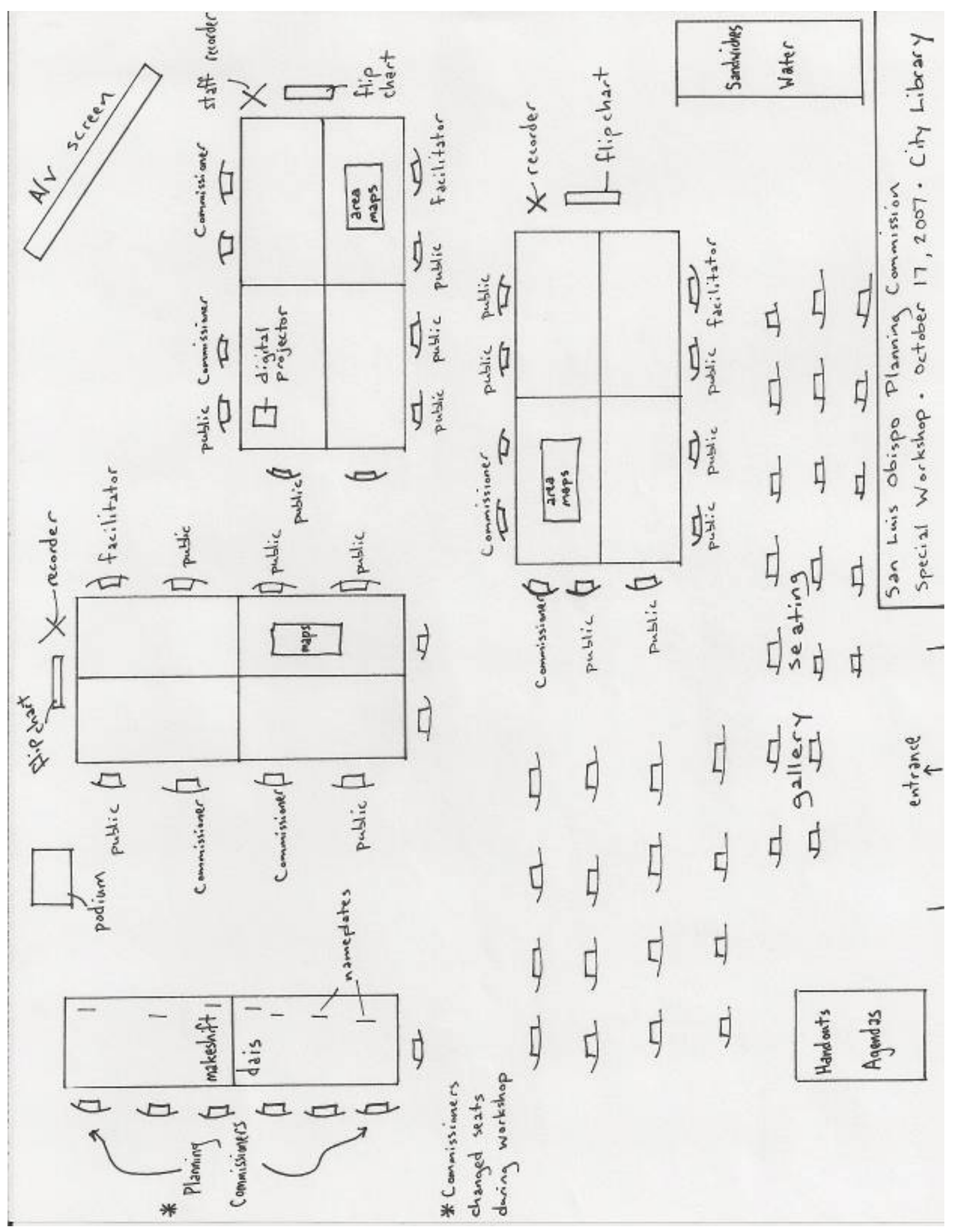


Case Study \#H2

\begin{tabular}{|c|c|}
\hline \multicolumn{2}{|l|}{ General data } \\
\hline event title & $\begin{array}{l}\text { San Luis Obispo Planning Commission } \\
\text { Regular Meeting }\end{array}$ \\
\hline methodology & Public hearing \\
\hline location & $\begin{array}{l}\text { Council Chamber } \\
\text { City Hall - 990 Palm } \\
\text { San Luis Obispo, CA } 93401\end{array}$ \\
\hline date and time & $\begin{array}{l}11 / 28 / 2007 \\
7: 00 \mathrm{pm}\end{array}$ \\
\hline $\begin{array}{l}\text { mediator(s) } \\
\text { (number of } \\
\text { presenters) }\end{array}$ & $\begin{array}{l}\text { Pam Ricci, project planner } \\
\text { Doug Davidson, supervisor }\end{array}$ \\
\hline event duration & 3 hours and 15 minutes \\
\hline attendance & $\begin{array}{l}45 \text { gallery } \\
7 \text { commissioners } \\
5 \text { staff ( } 3 \text { planning, } 1 \text { legal, } 1 \text { recorder) } \\
2 \text { consultants (EIR \& architect) } \\
\end{array}$ \\
\hline early departures & $5 \%$ early \\
\hline late arrivals & 8 public \\
\hline weather & 60 degrees, cool \\
\hline members & $\begin{array}{l}\text { Commission: Dan Carpenter, Michael Multari, John Ashbaugh, } \\
\text { Amanda Brodie, Diana Gould-Wells, Charles Stevenson and Carlyn } \\
\text { Christianson }\end{array}$ \\
\hline
\end{tabular}




\begin{tabular}{|c|c|c|}
\hline \multicolumn{3}{|c|}{ Meeting Characteristics } \\
\hline $\begin{array}{l}\text { purpose/focus of } \\
\text { meeting }\end{array}$ & \multicolumn{2}{|c|}{$\begin{array}{l}\text { Review of updated Chinatown mixed-use development project. } \\
\text { Receive guidance from Commission on adequacy of final EIR. No } \\
\text { action taken. }\end{array}$} \\
\hline $\begin{array}{l}\text { level of dialogue } \\
\text { staff to public } \\
\text { public to public }\end{array}$ & \multicolumn{2}{|l|}{$\begin{array}{l}\text { Commissioners all looking downward at report } \\
\text { Staff making eye contact with Commissioners } \\
\text { Public looking at PPT, agenda } \\
\text { Sporadic soft conversation in gallery }\end{array}$} \\
\hline $\begin{array}{l}\text { speaker duration } \\
\text { staff vs. public }\end{array}$ & $\begin{array}{l}\text { 1. Commissioner's call to order, roll call, } \\
\text { agenda review ( } 10 \mathrm{~min}) \\
\text { 2. Staff PPT presentation ( } 20 \mathrm{~min}) \\
\text { 3. EIR consultant PPT presentation ( } 10 \\
\text { min) } \\
\text { 4. Architect PPT presentation ( } 30 \mathrm{~min}) \\
\text { 5. Questions from Commission ( } 20 \mathrm{~min} \text { ) } \\
\text { 6. Public comment ( } 30 \mathrm{~min}) \\
\text { 7. Break ( } 15 \mathrm{~min}) \\
\text { 8. Staff response ( } 15 \mathrm{~min}) \\
\text { 9. Commissioners response ( } 45 \mathrm{~min})\end{array}$ & $\begin{array}{l}\text { Planner: } 19 \% \\
\text { Consultants: } 22 \% \\
\text { Commission: } 42 \% \\
\text { Public: } 17 \%\end{array}$ \\
\hline $\begin{array}{l}\text { visualization tools } \\
\text { maps, posters, } \\
\text { digital, } \\
\text { pamphlet }\end{array}$ & \multicolumn{2}{|c|}{$\begin{array}{l}\text { Ceiling mounted projector and drop-down screen in corner for } \\
\text { presentations. } \\
\text { Staff PPT: text, maps } \\
\text { Consult. PPT: text, maps, 3D Sketchup snapshots } \\
\text { 3D Flythrough animation of proposed project } \\
1 \text { handout: agenda with staff report } \\
\text { General public: blown-up photos of historic buildings in context }\end{array}$} \\
\hline structure & \multicolumn{2}{|c|}{$\begin{array}{l}\text { Formal hearing (Robert's Rules of Order). All attention focused on } \\
\text { Commissioners and PPT. Chairs unmovable, fixed seating position. } \\
\text { Public are peripheral in regular meeting of advisory body and staff. }\end{array}$} \\
\hline Setting & \multicolumn{2}{|c|}{$\begin{array}{l}\text { Lecture hall; theatre seating } \\
\text { Commissioners on raised dais facing public audience (stage center) } \\
\text { Staff flanking commissioners, faced inwards towards dais } \\
\text { City, State and Country flags adorn dais } \\
\text { Public relegated to gallery seating }\end{array}$} \\
\hline $\begin{array}{l}\text { stage in planning } \\
\text { process }\end{array}$ & \multicolumn{2}{|c|}{$\begin{array}{l}\text { Middle of the road. Final } 2 \text { steps in the EIR process. } \\
2 \text { more PC meetings to go yet. }\end{array}$} \\
\hline $\begin{array}{l}\text { method of } \\
\text { interaction }\end{array}$ & \multicolumn{2}{|l|}{ Oratory/listener } \\
\hline $\begin{array}{l}\text { public notification } \\
\text { method }\end{array}$ & \multicolumn{2}{|c|}{ Sign postings, newspaper, City website, postcards } \\
\hline
\end{tabular}




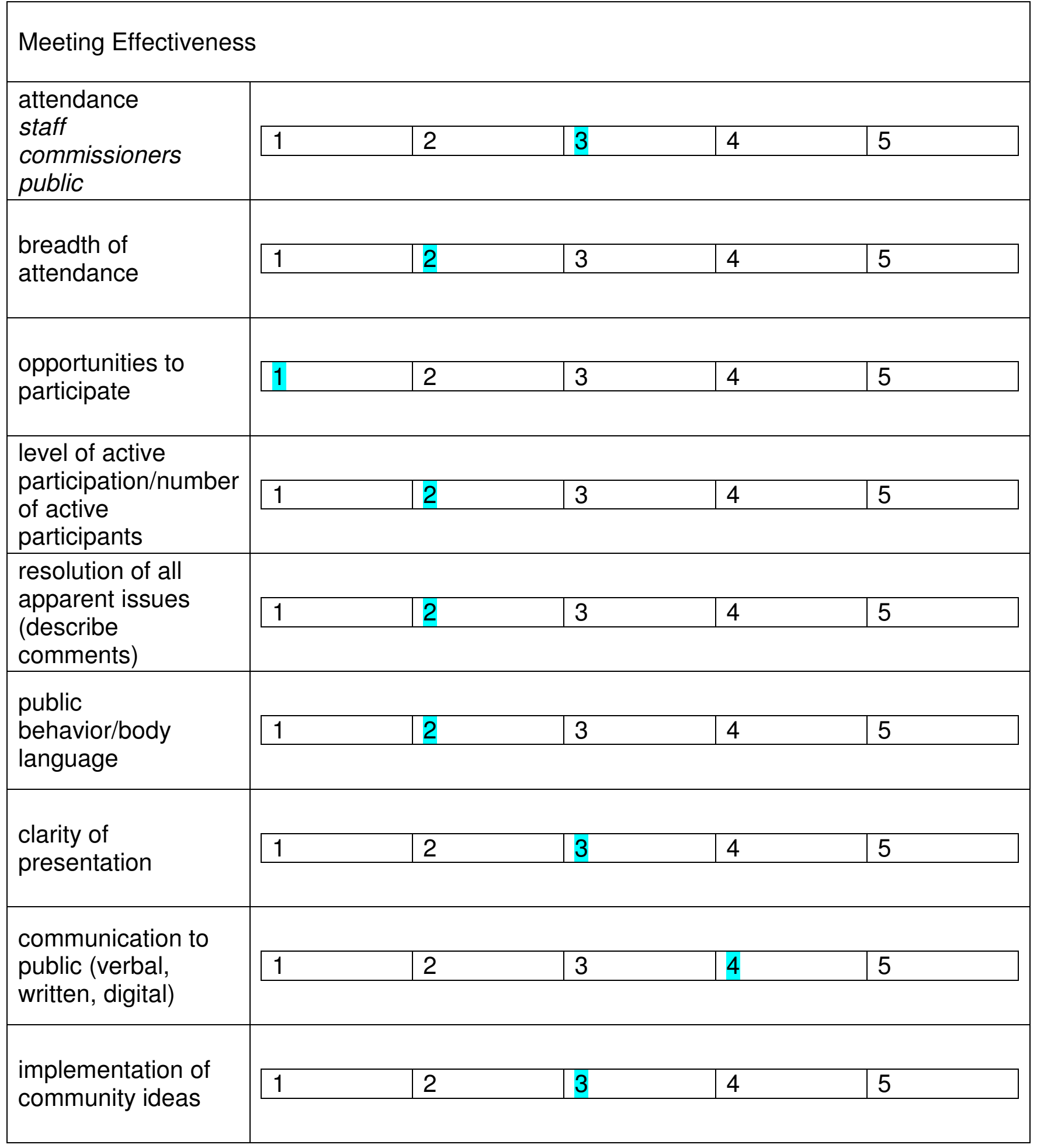




\section{Further Observations}

There were no smiles in the Council Chambers. The mood was very dry and somber. The public waited 1 hour and 20 minutes before their voices could be heard.

Most of the public comment was pre-prepared and not specifically relevant to the stated purpose of the meeting. As comments proceeded, public testimonials got increasingly more emotional. All focus was on the proposed demolition of two historic buildings. The message was clear from the community participants: Preserve the Sauer Bakery and Blackstone Hotel buildings.

Long-time residents pleaded for the City to preserve the integrity, historical character, and legacy of their ancestors. The majority of public comment was negative reactionary testimonial from senior citizens. One gentleman commented that he did not "trust a simulation".

Comments ran well over the directed 3 minute time limit. 


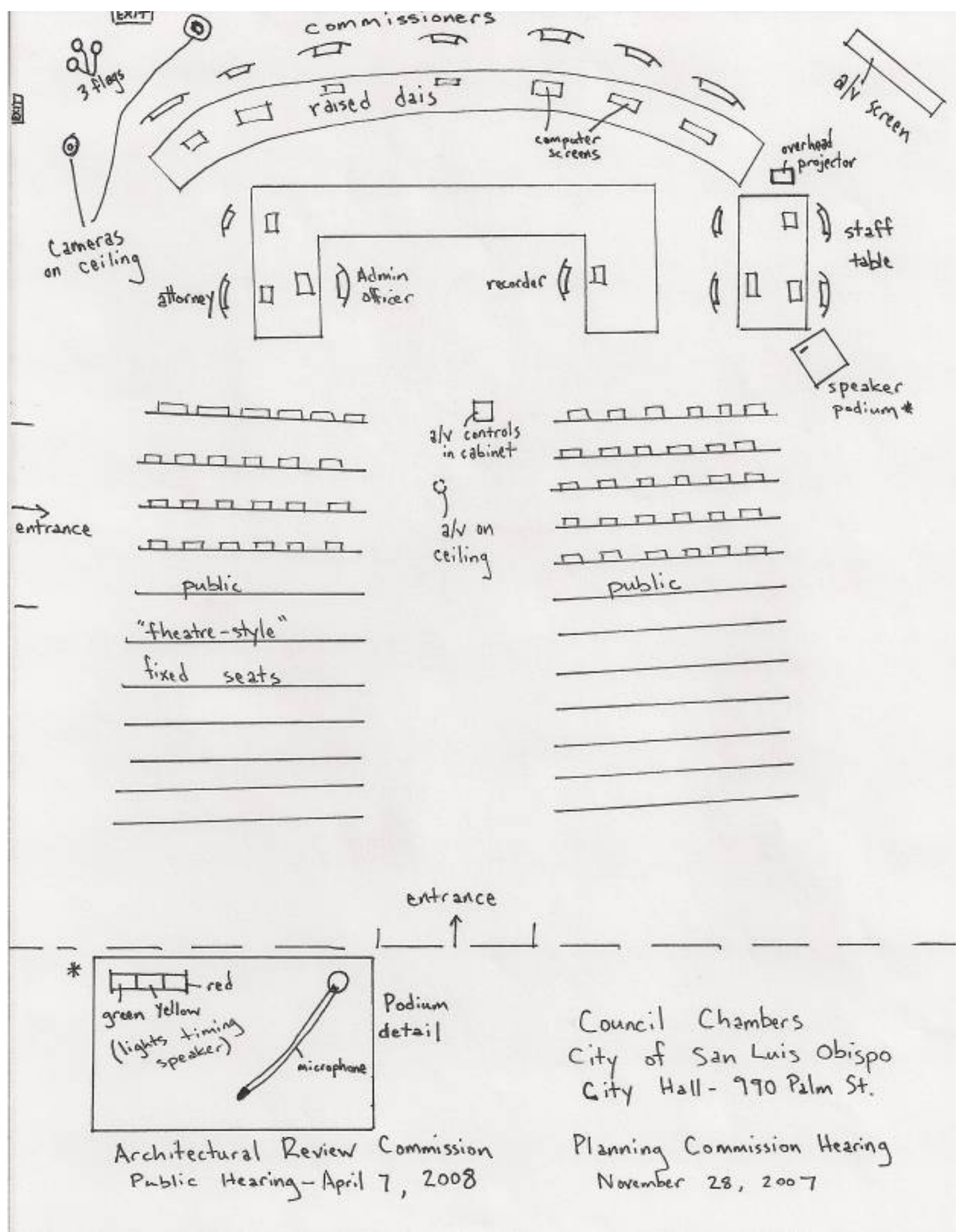


Case Study \#H3

\begin{tabular}{|c|c|}
\hline \multicolumn{2}{|l|}{ General data } \\
\hline event title & $\begin{array}{l}\text { San Luis Obispo } \\
\text { Architectural Review Commission Regular Meeting }\end{array}$ \\
\hline methodology & Public hearing \\
\hline location & $\begin{array}{l}\text { City Hall, Council Chambers } \\
\text { 990 Palm Street } \\
\text { San Luis Obispo, CA } 93401\end{array}$ \\
\hline date and time & $\begin{array}{l}04 / 07 / 2008 \\
5: 00 \mathrm{pm}\end{array}$ \\
\hline $\begin{array}{l}\text { mediator(s) } \\
\text { (number of } \\
\text { presenters) }\end{array}$ & $\begin{array}{l}\text { Chairperson Allen Root } \\
\text { Staff Liaison Pam Ricci }\end{array}$ \\
\hline event duration & 2.5 hours \\
\hline attendance & 64 public, 6 advisory body, 5 staff \\
\hline early departures & 51 public \\
\hline late arrivals & 5 public \\
\hline weather & 55 degrees, clear \\
\hline members & $\begin{array}{l}\text { Architectural Review Commission } \\
\text { City Attorney }\end{array}$ \\
\hline
\end{tabular}




\begin{tabular}{|c|c|c|}
\hline \multicolumn{3}{|c|}{ Meeting Characteristics } \\
\hline $\begin{array}{l}\text { purpose/focus of } \\
\text { meeting }\end{array}$ & \multicolumn{2}{|c|}{$\begin{array}{l}\text { Regular meeting of the ARC to consider two projects: (1) Hotel } \\
\text { remodel and (2) Mitchell Park Senior Center Parking Lot. First item } \\
\text { was continued without discussion. }\end{array}$} \\
\hline $\begin{array}{l}\text { level of dialogue } \\
\text { staff to public } \\
\text { public to public }\end{array}$ & \multicolumn{2}{|c|}{$\begin{array}{l}\text { Dialogue was entirely directed to the advisory body members. Staff } \\
\text { presented the project and recommendation, followed by questions } \\
\text { from the Commissioners. Public Comment was relegated to } 3 \text { minutes } \\
\text { per person. There was substantial comment from residents for and } \\
\text { against a new parking lot for the local Senior Center. }\end{array}$} \\
\hline $\begin{array}{l}\text { speaker duration } \\
\text { staff vs. public }\end{array}$ & $\begin{array}{l}\text { 10. Staff }(20 \mathrm{~min}) \\
\text { 11. Commissioners }(60 \mathrm{~min}) \\
\text { 12. Public Comment }(60 \mathrm{~min}) \\
\text { 13. Planning Staff }(10 \mathrm{~min})\end{array}$ & $\begin{array}{l}\text { Staff: } 20 \% \\
\text { Commissioners: } \\
40 \% \\
\text { Public: } 40 \%\end{array}$ \\
\hline $\begin{array}{l}\text { visualization tools } \\
\text { maps, posters, } \\
\text { digital, } \\
\text { pamphlet }\end{array}$ & \multicolumn{2}{|c|}{$\begin{array}{l}\text { PPT, audiovisual screen, large scale site plans posted on wall, } \\
\text { agenda handouts, petitions and picket signs from public. }\end{array}$} \\
\hline structure & \multicolumn{2}{|c|}{$\begin{array}{l}\text { Formal public hearing. Chairperson opens the meeting with Pledge of } \\
\text { Allegiance, followed by public comment about items not on the agenda. Next } \\
\text { staff presents project overview and recommendation for action by } \\
\text { Commission. ARC questioned staff and then opened up public hearing. } \\
\text { Each person that wanted to comment submitted a speaker card earlier in the } \\
\text { meeting and the Chair called them up my name. Residents stated name, } \\
\text { address, and then concerns. Chair thanked each one, no other response } \\
\text { from Commissioners. After public comments, Commissioners deliberate and } \\
\text { make a motion. The meeting ends with staff providing an "agenda forecast" } \\
\text { of what is to be heard at the next regular meeting. }\end{array}$} \\
\hline setting & \multicolumn{2}{|c|}{$\begin{array}{l}\text { Council Chambers: fixed rows of padded "theatre" seats for public, slight } \\
\text { incline in floor moving towards front of room where staff seats are located. } \\
\text { Staff seated perpendicular to public, facing one another across room. } \\
\text { Commission raised two steps up at front of room on dais facing public. } \\
\text { Computer screens in glass topped desks, microphones, and nameplates for } \\
\text { staff and ARC. Audiovisual screen behind Commissioners facing public. } \\
\text { Windows on one side, large double doors on the other, regular man-door in } \\
\text { back. Three flags (Fed, State, local) in corner with cameras placed around } \\
\text { room mounted to wall for local TV broadcast. }\end{array}$} \\
\hline $\begin{array}{l}\text { stage in planning } \\
\text { process } \\
\left(1^{\text {st }}, 2^{\text {nd }}, 3^{\text {rd }}\right. \\
\text { meeting })\end{array}$ & \multicolumn{2}{|c|}{$\begin{array}{l}\text { Second hearing of five: } \\
\text { 1. CHC 2. ARC (policy) 3. Council (policy) 4. ARC (design) 5. Council } \\
\text { (design) }\end{array}$} \\
\hline $\begin{array}{l}\text { method of } \\
\text { interaction }\end{array}$ & \multicolumn{2}{|c|}{$\begin{array}{l}\text { Oratory/listener, question and answer. Meeting governed by Robert's } \\
\text { Rules of Order. }\end{array}$} \\
\hline public notification & \multicolumn{2}{|c|}{ Website, legal ads, local newspaper, postcards } \\
\hline
\end{tabular}




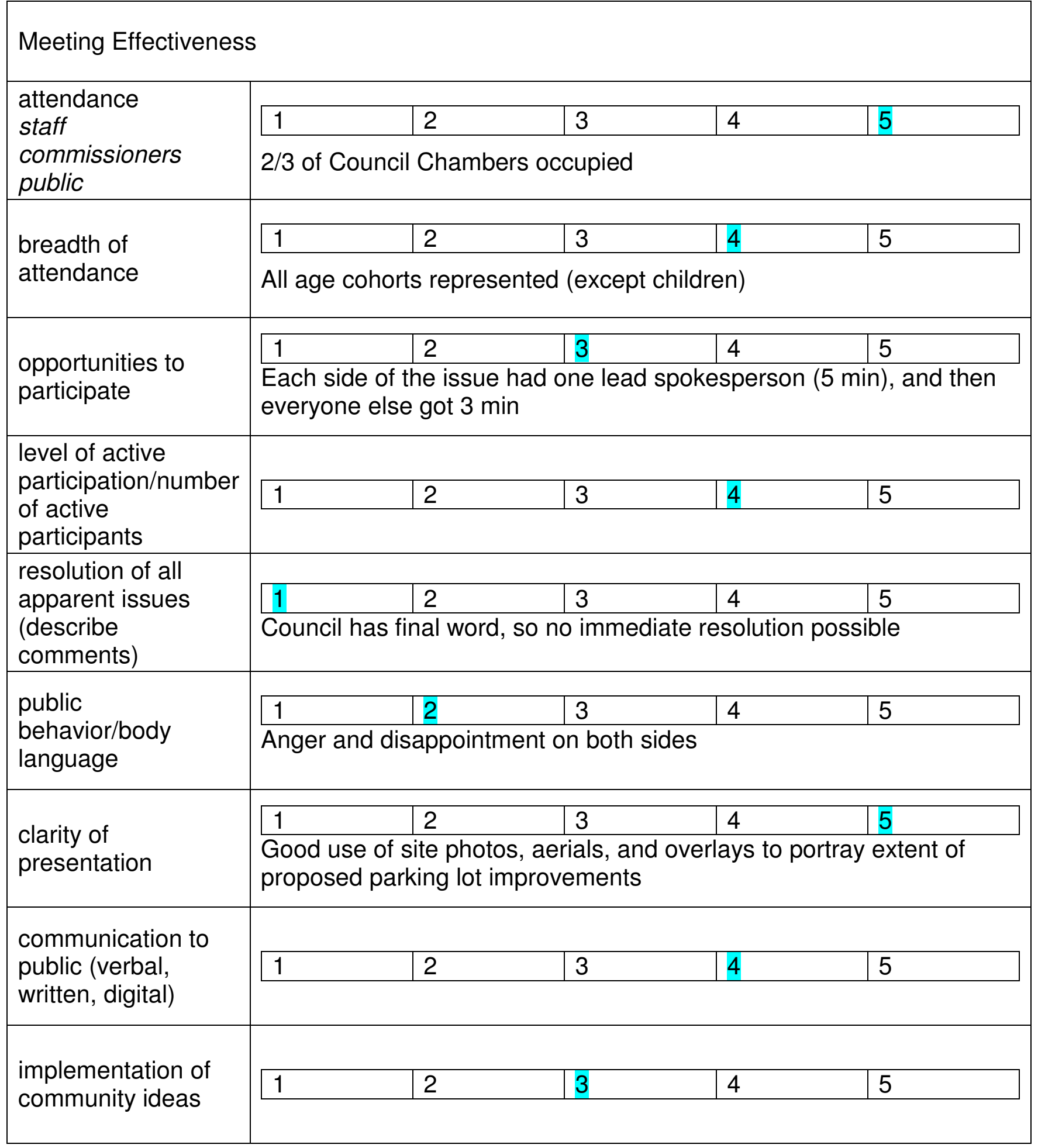




\section{Further Observations}

The Council Chambers were divided down the middle like two angry families at an ill-fated wedding. Residents representing opposition to the proposed parking lot outnumbered the Senior residents who supported plans to amend the Mitchell Park Master Plan to accommodate new parking facilities. The proposed 12 space lot would replace an underutilized shuffleboard court and barbecue area.

The opposition was well organized and even brought picket signs that read, "Say No to Mitchell Parking lot" and "I Love Mitchell Park". They waved them in the audience when a resident would say something against the parking lot plans at the podium. A petition was signed by over 680 people opposing the parking lot plans. The seniors had their own petition with over 180 signatures in favor of the lot. They also provided emotional testimony about those patrons of the Senior Center with mobility issues, and how a parking lot would alleviate their struggle. Interestingly, no one denied there was a problem. The surrounding blocks are always impacted with parked cars early in the day, rendering if very difficult for seniors to access the building because they usually arrived later. Major dissension was over the City's solution to the problem.

Many residents suggested alternatives such as Rideshare, parking districts, free bus passes, etc. It became clear as the hearing progressed that opposition was based on a fundamental belief that urban parks are precious and not a single foot should be paved over for automobiles. Idealism outshined realism as angry neighbors were quoting a Joni Mitchell song about "Paving Paradise" at the podium. For seniors, the lot was the most practical solution. They did not speak in favor of redeveloping parks or paving over the whole site. Instead they simply wanted a small area that was already underutilized to serve as exclusive parking for a public facility that has zero parking now.

Residents also spoke out about being informed too late in the process. The Parks and Recreation Department held a community meeting at the Senior Center over a year ago, yet many neighbors claimed no knowledge of it. It is apparent that some of the angst over the parking solution could have been avoided if better noticing and earlier meetings had taken place. The project seemed to already have been decided at this point. Construction of a parking lot was already identified as a "Major City Goal" in the City's Fiscal Plan, which was drafted a year ago. According to follow up staff interviews, the goal for a parking lot was adopted largely because the seniors came out in full force to previous hearings about what to include in the City's Fiscal Plan. Contrary to the staff recommendation, the Commission voted against the parking lot plans. They made a motion to the Council to either relocate the Senior Center or consider parking alternatives.

This public hearing was the most emotionally charged public meeting observed thus far. When issues hit home in people's neighborhoods, residents will go to great lengths to support or oppose the issue based on their personal interests. The neighbors opposing put together a "savemitchellpark.org" website and spoke with a unified voice at the hearing. Whether or not the Council hears this collective cry is yet to be seen. The most interesting part of the whole public hearing was immediately after the formalities were over. Many residents that opposed the lot sought out seniors and tried to reason with them. Face to face communication occurred after the public participation event ended! 


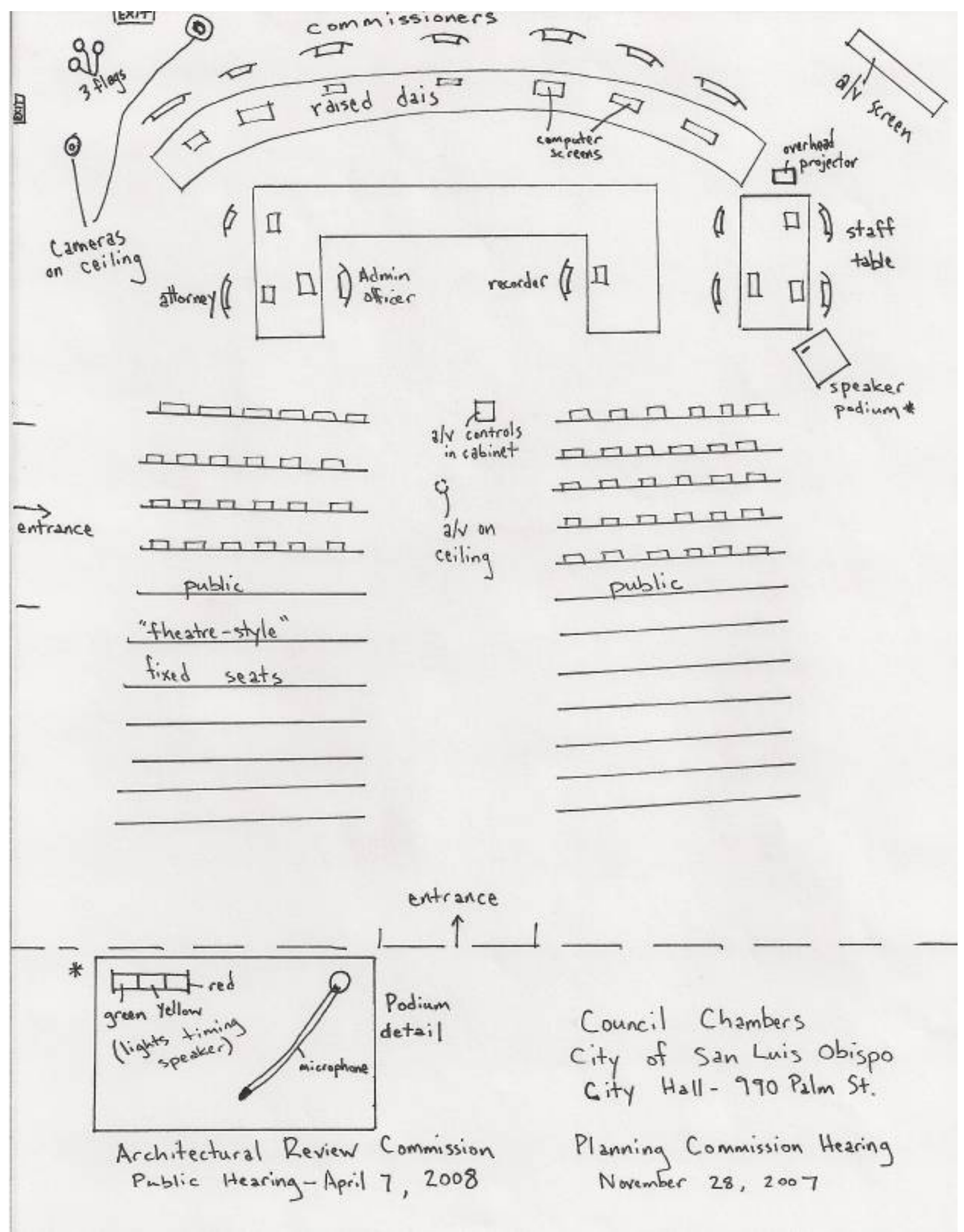




\section{Case Study \#W2}

\begin{tabular}{|c|c|}
\hline \multicolumn{2}{|l|}{ General data } \\
\hline event title & $\begin{array}{l}\text { Vision for Guadalupe } 2030 \\
\text { Community Meeting ( } 1 \text { of } 5 \text { ) }\end{array}$ \\
\hline methodology & Public Workshop Series \\
\hline location & $\begin{array}{l}\text { Council Meeting Room } \\
918 \text { Obispo Street } \\
\text { Guadalupe, CA } 93434\end{array}$ \\
\hline date and time & $\begin{array}{l}10 / 23 / 2008 \\
6: 30 \mathrm{pm}\end{array}$ \\
\hline $\begin{array}{l}\text { mediator(s) } \\
\text { (number of } \\
\text { presenters) }\end{array}$ & $\begin{array}{l}\text { California Polytechnic State University } \\
\text { City and Regional Planning } \\
1 \text { moderator }\end{array}$ \\
\hline event duration & 2 hours \\
\hline attendance & $\begin{array}{l}24 \text { public } \\
3 \text { Council members } \\
13 \text { Cal Poly }\end{array}$ \\
\hline early departures & 4 public \\
\hline late arrivals & 4 public \\
\hline weather & 75 degrees, clear \\
\hline members & City Manager, 2 Council member \\
\hline
\end{tabular}




\begin{tabular}{|c|c|c|}
\hline $\begin{array}{l}\text { purpose/focus of } \\
\text { meeting }\end{array}$ & \multicolumn{2}{|c|}{$\begin{array}{l}\text { Focus group meeting to learn community desires and review the } \\
\text { General Plan. Residents were asked to prioritize their favorite ideas } \\
\text { for Guadalupe's future. }\end{array}$} \\
\hline $\begin{array}{l}\text { level of dialogue } \\
\text { staff to public } \\
\text { public to public }\end{array}$ & \multicolumn{2}{|c|}{$\begin{array}{l}\text { Brief introductory presentation from City and Regional Planning (CRP) } \\
\text { moderators. Majority of meeting was breakout tables where CRP } \\
\text { facilitators guided discussion of community interests amongst } \\
\text { residents. }\end{array}$} \\
\hline $\begin{array}{l}\text { speaker duration } \\
\text { staff vs. public }\end{array}$ & $\begin{array}{l}\text { 14. CRP Introduction ( } 20 \mathrm{~min}) \\
\text { 15. Discussion Groups ( } 45 \mathrm{~min}) \\
\text { 16. Group Presentations ( } 30 \mathrm{~min}) \\
\text { 17. Wrap-up ( } 25 \mathrm{~min})\end{array}$ & $\begin{array}{l}\text { Cal Poly: } 38 \% \\
\text { Public: } 63 \%\end{array}$ \\
\hline $\begin{array}{l}\text { visualization tools } \\
\text { maps, posters, } \\
\text { digital, } \\
\text { pamphlet }\end{array}$ & \multicolumn{2}{|c|}{$\begin{array}{l}\text { Portable digital projector, PPT, flip-chart easels for group note-taking, } \\
\text { aerial photos and maps on boards, posters, markers, "wish list" } \\
\text { exercise, "likes, dislikes, and changes" exercise. }\end{array}$} \\
\hline structure & \multicolumn{2}{|c|}{$\begin{array}{l}\text { Informal workshop with multiple breakout tables. Meeting was } \\
\text { designed to get residents talking about their community. Each resident } \\
\text { completed a "wish list" for Guadalupe. Small groups used these initial } \\
\text { brainstorms in a subsequent three-part exercise: } \\
\text { 4. What do you like about Guadalupe? } \\
5 \text {. What do you dislike about Guadalupe? } \\
\text { 6. What improvements would you like to see in your community? } \\
\text { Participants were also asked to prioritize their favorite ideas for the } \\
\text { future of Guadalupe. One member from each group presented small } \\
\text { group findings to the larger whole. Refreshments (water, coffee, } \\
\text { snacks) were available throughout. }\end{array}$} \\
\hline setting & \multicolumn{2}{|c|}{$\begin{array}{l}\text { Back of Council Chambers (movable wall sectioned this area off from } \\
\text { more formal dais) } \\
\text { Four large rectangular tables; six persons per table } \\
\text { Designated one discussion table for Spanish speakers } \\
\text { Three students (facilitator, recorder and note-taker) per table }\end{array}$} \\
\hline $\begin{array}{l}\text { stage in planning } \\
\text { process } \\
\left(1^{\text {st }}, 2^{\text {nd }}, 3^{\text {rd }}\right. \\
\text { meeting })\end{array}$ & \multicolumn{2}{|c|}{$\begin{array}{l}\text { First meeting in five meeting series. Early stages of visioning process } \\
\text { for Guadalupe } 2030 \text { community plan. }\end{array}$} \\
\hline $\begin{array}{l}\text { method of } \\
\text { interaction }\end{array}$ & \multicolumn{2}{|c|}{ Oratory/listener, active dialogue, small group exercises } \\
\hline $\begin{array}{l}\text { public notification } \\
\text { method }\end{array}$ & \multicolumn{2}{|c|}{$\begin{array}{l}\text { Flyers handed out in-person on the streets and at public schools, and } \\
\text { included with prior month's water bill. Also posted on City's website. }\end{array}$} \\
\hline
\end{tabular}




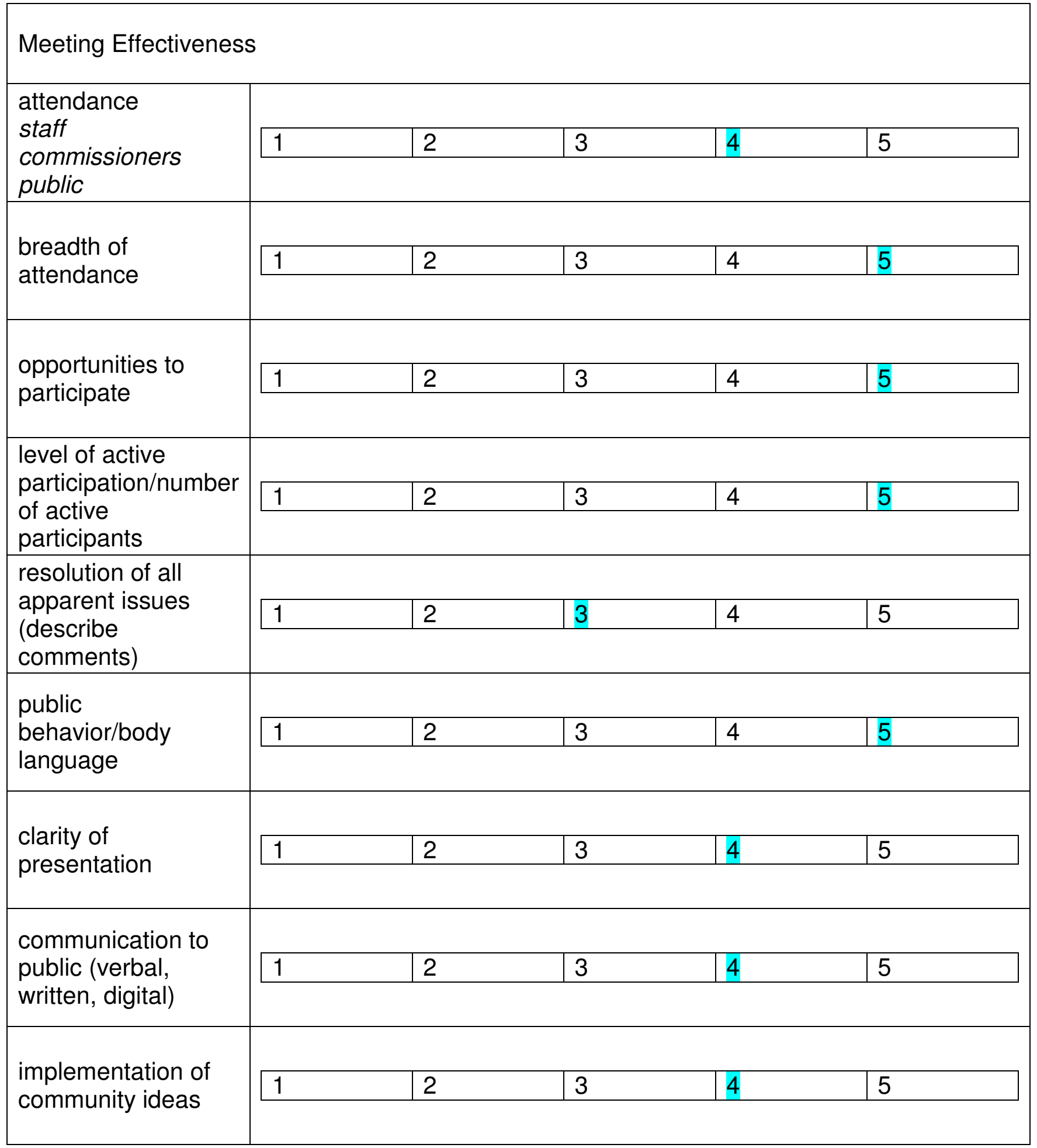


Further Observations

The setting enabled face to face interaction amongst residents around a table. This equalized the playing field between Council member and average resident. Breakout tables also encourage eye contact among all participants which can be more direct and less confrontational.

Tables were self-selected and ended up slightly segregated. There was one Spanish-speaking table that was mostly residents of Latino descent. The City Manager chose to sit with the two Council members and a consultant who works for the City. The other two tables were a good mix of ages and ethnicity.

Every generation was represented from young adults to retired seniors. Varying classes of society could be inferred by the different clothes people wore; service men mixed with executives with a common bond of citizenry.

The "wish list" was an excellent exercise because it got people thinking about the future they'd like to see in Guadalupe and also provided a written record of community desires that CRP planners and the City could use in formulating the Community Plan. Residents used their wish lists as a reference during subsequent discussion sessions about likes, dislikes and changes for Guadalupe.

Facilitators began breakout sessions with a round of introductions. This helped reduce the uneasy feeling of talking openly with strangers. People used personal stories to establish credibility when making claims. "I've lived in Guadalupe for 14 years, and I can remember when...".

Discussion questions were posted on PowerPoint slides to remind people of the focus of the meeting. Laughter was evident when people talked about likes, and heated discussion was observed when talking about dislikes. Proposed improvements/solutions were similar to stated needs.

One member from each group presented back to the whole with their groups top six likes, dislikes and improvements. Passing the microphone from group to group gave people a sense of ownership of the meeting. There was clapping after every mini-presentation.

Community members want beautify downtown by attracting new business and urban landscaping. Some felt a need to promote tourism, target growth along Guadalupe Street, increase walkability and the connection to the Dunes, Concerns were apparent about recently approved development of prime farm land into 900 new dwellings to the south of downtown.

Top 6 Improvements needed: Consistent facades downtown, redevelopment of Leroy Park, fix 11th and N. Pioneer St., continue lighting on Guadalupe, more access to Santa Maria, sidewalk extensions/bulb-outs.

What people like about Guadalupe: People, small with few problems, small town feel, local markets, restaurants, known for good athletes, unique environment - dunes, murals, housing from People's self-help. 


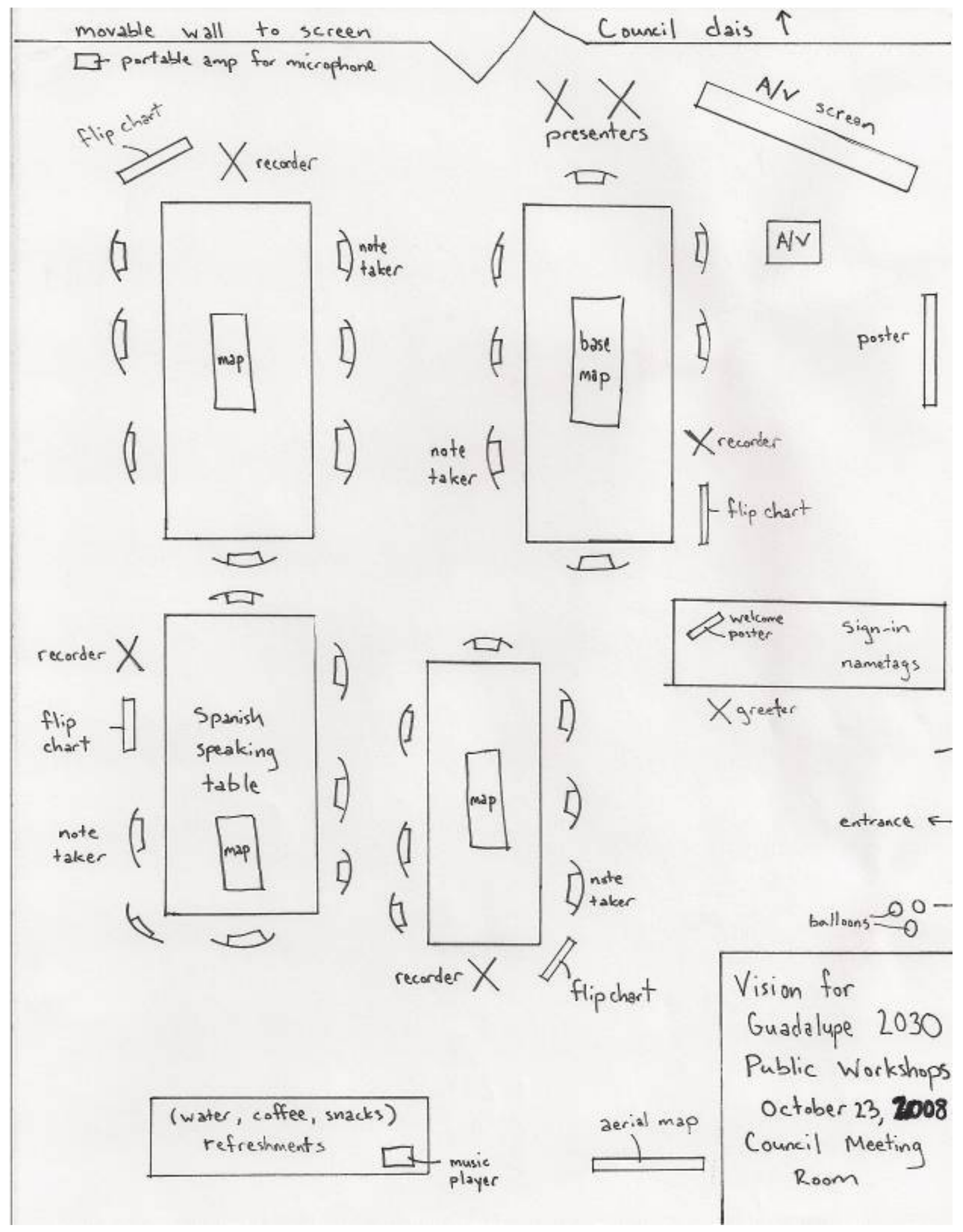




\section{Case Study \#W3}

\begin{tabular}{|c|c|}
\hline \multicolumn{2}{|l|}{ General data } \\
\hline event title & $\begin{array}{l}\text { Vision for Guadalupe } 2030 \\
\text { Community Meeting ( } 2 \text { of } 5 \text { ) }\end{array}$ \\
\hline methodology & Public Workshop Series \\
\hline location & $\begin{array}{l}\text { Council Meeting Room } \\
918 \text { Obispo Street } \\
\text { Guadalupe, CA } 93434\end{array}$ \\
\hline date and time & $\begin{array}{l}11 / 20 / 2008 \\
6: 30 \mathrm{pm}\end{array}$ \\
\hline $\begin{array}{l}\text { mediator(s) } \\
\text { (number of } \\
\text { presenters) }\end{array}$ & $\begin{array}{l}\text { California Polytechnic State University } \\
\text { City and Regional Planning (CRP) } \\
2 \text { presenters }\end{array}$ \\
\hline event duration & 2 hours \\
\hline attendance & $\begin{array}{l}21 \text { public } \\
2 \text { Council members } \\
13 \text { Cal Poly }\end{array}$ \\
\hline early departures & 2 public \\
\hline late arrivals & 3 public \\
\hline weather & 68 degrees, clear \\
\hline members & Mayor Lupe Alvarez, 1 Council member \\
\hline
\end{tabular}




\begin{tabular}{|c|c|c|}
\hline $\begin{array}{l}\text { purpose/focus of } \\
\text { meeting }\end{array}$ & \multicolumn{2}{|c|}{$\begin{array}{l}\text { Show Guadalupe's visual character. Discuss current policies and } \\
\text { emerging directions. Review input from last meeting. }\end{array}$} \\
\hline $\begin{array}{l}\text { level of dialogue } \\
\text { staff to public } \\
\text { public to public }\end{array}$ & \multicolumn{2}{|c|}{$\begin{array}{l}\text { Meeting was primarily reporting findings based on a land use } \\
\text { inventory, research and previous community input. One way } \\
\text { communication, but public was free to interrupt at any time with } \\
\text { questions. Q\&A poster session granted more opportunity for genuine } \\
\text { participation. }\end{array}$} \\
\hline $\begin{array}{l}\text { speaker duration } \\
\text { staff vs. public }\end{array}$ & $\begin{array}{l}\text { 18. CRP Presentation }(60 \mathrm{~min}) \\
\text { 19. Feedback Tables }(40 \mathrm{~min}) \\
\text { 20. Wrap-up }(20 \mathrm{~min})\end{array}$ & $\begin{array}{l}\text { Cal Poly: } 67 \% \\
\text { Public: } 33 \%\end{array}$ \\
\hline $\begin{array}{l}\text { visualization tools } \\
\text { maps, posters, } \\
\text { digital, } \\
\text { pamphlet }\end{array}$ & \multicolumn{2}{|c|}{$\begin{array}{l}\text { Portable digital projector, PPT, aerial photos and maps on boards, } \\
\text { posters, markers. }\end{array}$} \\
\hline structure & \multicolumn{2}{|c|}{$\begin{array}{l}\text { Formal presentation of research findings. Purpose was education and } \\
\text { critique from community being studied. Different elements were } \\
\text { broken into poster tables stationed with a CRP member available for } \\
\text { questions. Markers were available for any additions or changes. }\end{array}$} \\
\hline setting & \multicolumn{2}{|c|}{$\begin{array}{l}\text { Back of Council Chambers (movable wall sectioned this area off from } \\
\text { more formal dais) } \\
\text { Seats in rows, facing portable screen. Digital projection of slides } \\
\text { behind two speakers alternating elements. } \\
\text { After presentation, space brightened with light and discussion around } \\
\text { poster boards. Active participants in standing posture and enjoying } \\
\text { more refreshments. }\end{array}$} \\
\hline $\begin{array}{l}\text { stage in planning } \\
\text { process } \\
\left(1^{\text {st }}, 2^{\text {nd }}, 3^{\text {rd }}\right. \\
\text { meeting })\end{array}$ & \multicolumn{2}{|c|}{$\begin{array}{l}\text { Second meeting in five meeting series. Research stages of visioning } \\
\text { process for Guadalupe } 2030 \text { community plan. }\end{array}$} \\
\hline $\begin{array}{l}\text { method of } \\
\text { interaction }\end{array}$ & \multicolumn{2}{|l|}{ Oratory/listener, active dialogue } \\
\hline $\begin{array}{l}\text { public notification } \\
\text { method }\end{array}$ & \multicolumn{2}{|c|}{$\begin{array}{l}\text { Flyers handed out in-person on the streets and at public schools. } \\
\text { Posted on City's website. }\end{array}$} \\
\hline
\end{tabular}




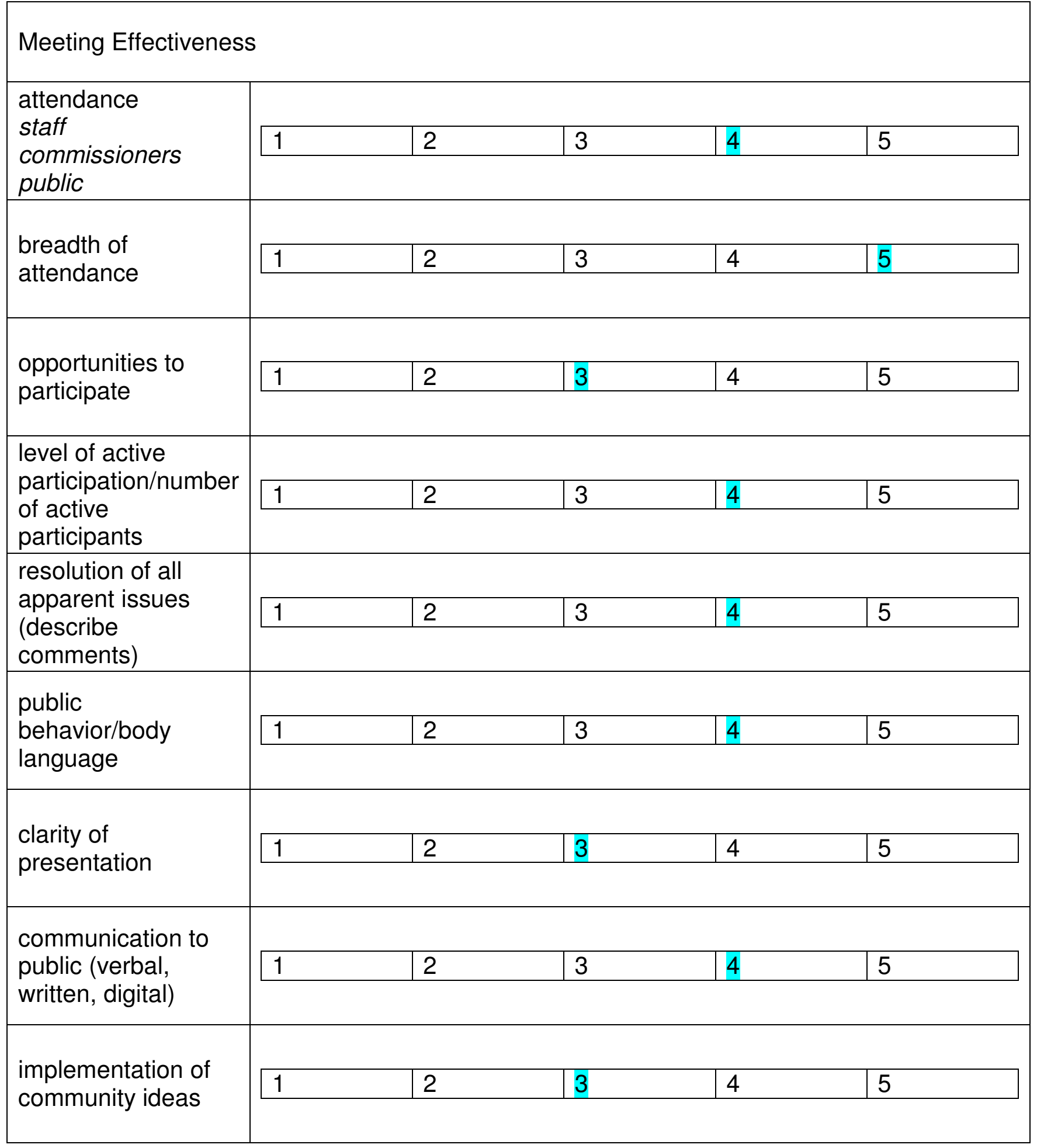


Further Observations

The presentation was based on participant's ideas presented at the October 23rd meeting, the Land Use Inventory and policy research. This data helped define "emerging directions" for Guadalupe. The intent was also to make sure that what was being proposed in emerging directions adequately reflected the community's interests.

Additional participant comments:

1. Provide a community center (Quincienaras celebrations, parties, and other activities).

2. Shared parking would be beneficial downtown so that the parking requirements are not as high for each business.

3. Residents like the idea of housing near Guadalupe Street, but the ground floor along the street should be reserved for other uses.

4. The flooding behind the Far Western Restaurant (?) forced houses to be removed.

5. Reroute and prohibit big trucks on residential streets (especially in the north side of the City).

6. Public faculties should be improved (schools need better playground design).

7. There are too many loose dogs, which makes walking unpleasant. A dog park could possibly remedy this.

8. Budget cuts took away the sports bus that shuttled kids to sports games in Santa Maria, so parents have to drive their kids there. Parents would like to see the sports bus brought back.

9. Bike races pass through Guadalupe on Highway 1 occasionally. The riders make pit stops at Leroy Park, so it would be nice if Leroy Park was improved.

Presentation was information heavy. Audience was engaged but passive. Fear of stopping presentation to ask questions may deter some from active input. Mayor made two observations about incorrect data.

Poster session was when communication opened up. Lighting changed, participants stood and discussed facts. Some just looked at posters. Dialogue often deviated from poster topic to personal opinions.

Attention spans wane after an hour. The meeting was dominated by the lengthy presentation. More opportunities up front for public discussion needed.

50 percent of attendees were recognizable from previous meeting. Mayor was in attendance for first time, which changes tone slightly due to authoritative presence. Moderator is same as last meeting, second presenter was new addition. 


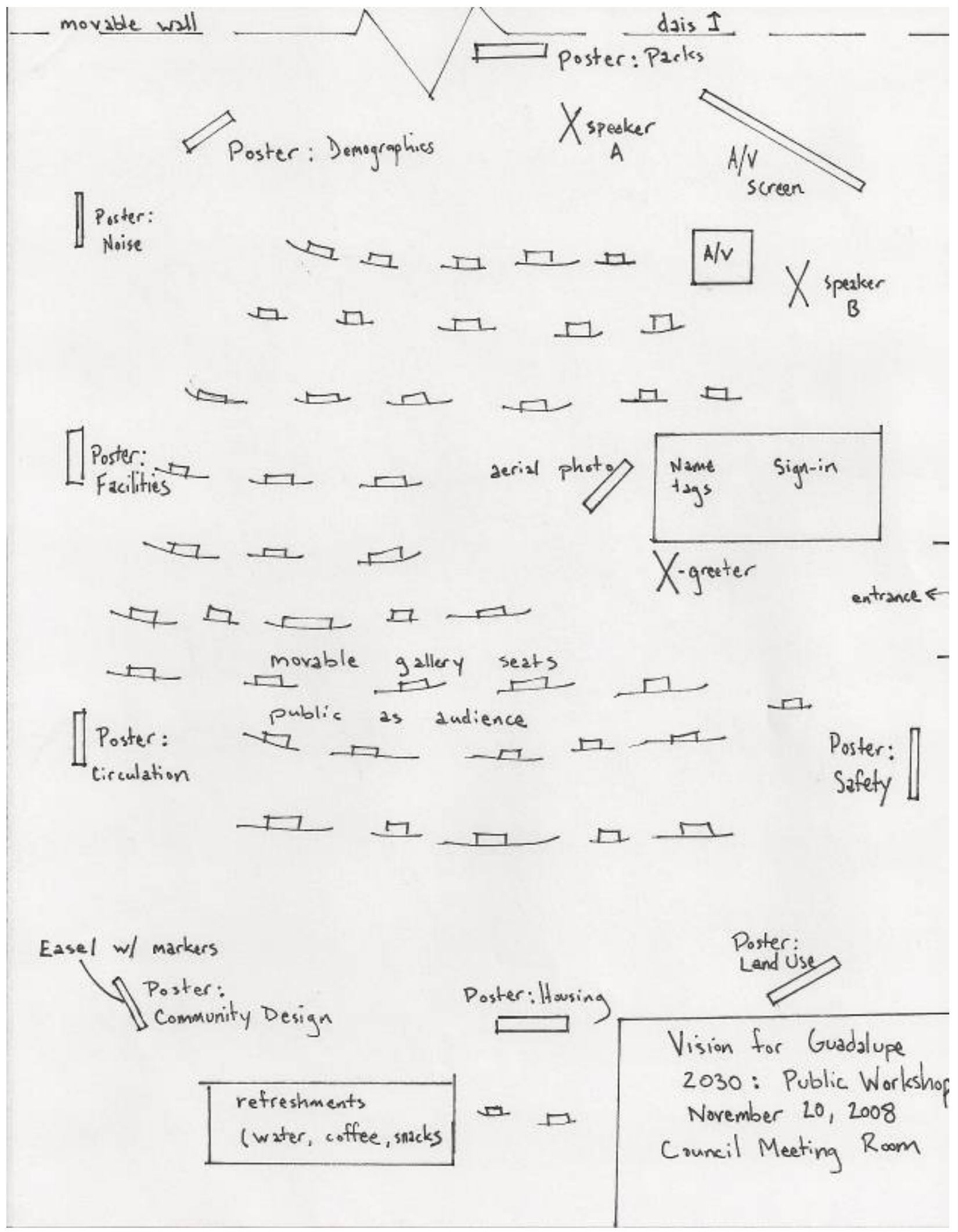

149 


\section{Case Study \#W4}

\begin{tabular}{|c|c|}
\hline \multicolumn{2}{|l|}{ General data } \\
\hline event title & $\begin{array}{l}\text { Vision for Guadalupe } 2030 \\
\text { Community Meeting (3 of } 5 \text { ) }\end{array}$ \\
\hline methodology & Public Workshop Series \\
\hline location & $\begin{array}{l}\text { Senior Center } \\
4545 \text { 10th Street } \\
\text { Guadalupe, CA } 93434\end{array}$ \\
\hline date and time & $\begin{array}{l}02 / 05 / 2009 \\
6: 30 \mathrm{pm}\end{array}$ \\
\hline $\begin{array}{l}\text { mediator(s) } \\
\text { (number of } \\
\text { presenters) }\end{array}$ & $\begin{array}{l}\text { California Polytechnic State University } \\
\text { City and Regional Planning (CRP) } \\
2 \text { presenters }\end{array}$ \\
\hline event duration & 2 hours \\
\hline attendance & $\begin{array}{l}15 \text { public } \\
\text { Mayor } \\
13 \text { Cal Poly }\end{array}$ \\
\hline early departures & 1 public \\
\hline late arrivals & 2 public \\
\hline weather & 50 degrees, clear \\
\hline members & Mayor Lupe Alvarez \\
\hline
\end{tabular}




\begin{tabular}{|c|c|c|}
\hline $\begin{array}{l}\text { purpose/focus of } \\
\text { meeting }\end{array}$ & \multicolumn{2}{|c|}{$\begin{array}{l}\text { Introduce draft goals and objectives based on previous meeting input } \\
\text { and outside research. Educate how public desires can translate into } \\
\text { policies and programs in a community plan. }\end{array}$} \\
\hline $\begin{array}{l}\text { level of dialogue } \\
\text { staff to public } \\
\text { public to public }\end{array}$ & \multicolumn{2}{|c|}{$\begin{array}{l}\text { Presentation is one way communication of draft policies crafted from } \\
\text { previous public input. Follow-up poster session displayed goals, } \\
\text { objectives, policies, and programs in written form for public to review } \\
\text { and comment to CRP consultants. Public to public dialogue is rare. }\end{array}$} \\
\hline $\begin{array}{l}\text { speaker duration } \\
\text { staff vs. public }\end{array}$ & $\begin{array}{l}\text { 21. Presentation of Draft Goals and } \\
\text { Objectives ( } 40 \mathrm{~min}) \\
\text { 22. Feedback Tables }(40 \mathrm{~min}) \\
\text { 23. Wrap-up ( } 20 \mathrm{~min})\end{array}$ & $\begin{array}{l}\text { Cal Poly: } 60 \% \\
\text { Public: } 40 \%\end{array}$ \\
\hline $\begin{array}{l}\text { visualization tools } \\
\text { maps, posters, } \\
\text { digital, } \\
\text { pamphlet }\end{array}$ & \multicolumn{2}{|c|}{$\begin{array}{l}\text { Portable digital projector, PPT, aerial photos and maps on boards, } \\
\text { posters displaying goals and objectives (text heavy), pens. }\end{array}$} \\
\hline structure & \multicolumn{2}{|c|}{$\begin{array}{l}\text { Critique session about draft goals and objectives. Formal presentation } \\
\text { followed by Q\&A with moderator. Public was invited to poster stations } \\
\text { to talk about proposed policies in more detail. }\end{array}$} \\
\hline setting & \multicolumn{2}{|c|}{$\begin{array}{l}\text { Bright and clean community room with small tables. Seats arranged in } \\
\text { rows for presentation. Projector and screen to one side of the room. } \\
\text { After presentation, seats and tables pushed into center to allow for } \\
\text { discussion around poster boards. Active participants in standing } \\
\text { posture and enjoying more refreshments. }\end{array}$} \\
\hline $\begin{array}{l}\text { stage in planning } \\
\text { process } \\
\left(1^{\text {st }}, 2^{\text {nd }}, 3^{\text {rd }}\right. \\
\text { meeting })\end{array}$ & \multicolumn{2}{|c|}{$\begin{array}{l}\text { Third meeting in five meeting series. Policymaking stage of visioning } \\
\text { process for Guadalupe } 2030 \text { community plan. }\end{array}$} \\
\hline $\begin{array}{l}\text { method of } \\
\text { interaction }\end{array}$ & \multicolumn{2}{|l|}{ Oratory/listener, active dialogue } \\
\hline $\begin{array}{l}\text { public notification } \\
\text { method }\end{array}$ & \multicolumn{2}{|c|}{$\begin{array}{l}\text { Flyers handed out in-person on the streets and at public schools. } \\
\text { Posted on City's website. }\end{array}$} \\
\hline
\end{tabular}




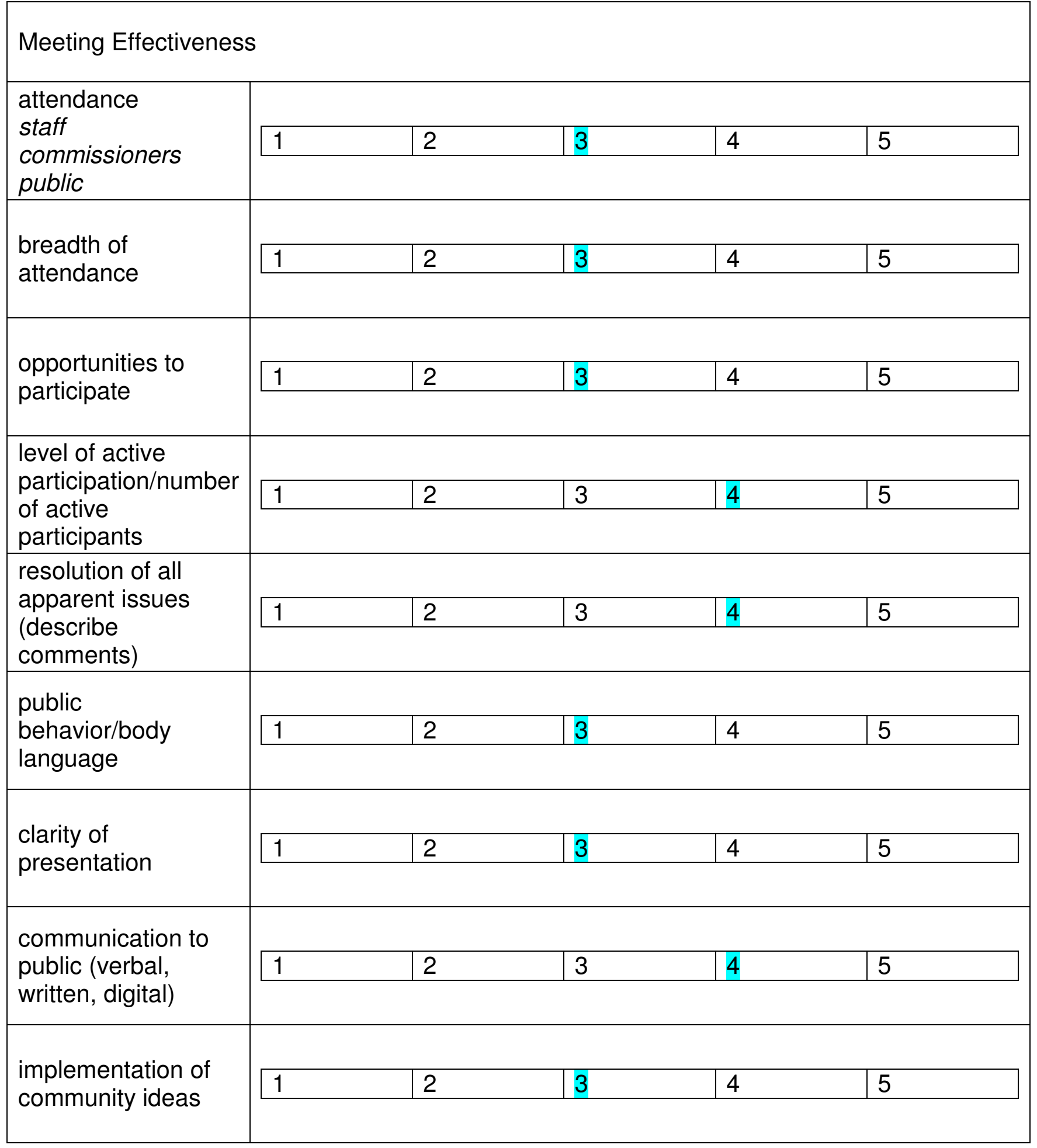


Further Observations

As community plan progresses the workshop series becomes more like a public hearing. Given the master document is being compiled, more reporting is expected. The easiest way to gain feedback is to speak directly about key topics of the plan.

Reporting as the community plan document is being created helps maintain transparency, therefore establishing trust from community in planner.

The presentation shows how public input is translated into policies in a plan. Example: Public Input: Target growth along Guadalupe St.; walkability Goal: Transient-oriented infill downtown in the vicinity of Guadalupe Street Objective: Develop all vacant land in downtown core by 2030.

This "show your work" exercise shifts ownership to community participants. Planner's role is facilitator (also wordsmith).

Good use of images in presentation. PowerPoint was a little technical and pictures help participants identify with concepts. Images were a mixture of photos and Internet downloads.

There were too many CRP consultants at meeting. Planners almost outnumbered participants, which is a bit intimidating.

More disbelief was apparent among participants. Few people had attended previous meetings and some were skeptical about far-reaching goals. The Mayor set the tone by reminding CRP facilitators that there was no funding for some of the proposed programs. It doesn't cost anything to write down objectives, but to what extent they are attainable is valuable to residents. Some project credibility was lost.

Participants felt more comfortable asking questions in poster session than during PowerPoint. Limiting overall presentation and increasing small group discussion may increase active participation.

However, a certain cohesiveness of focus was lost during poster session. Off-topic conversations were common. A sense of importance is attached to a formal presentation. Residents come to give input, but are also largely motivated by a desire for information.

Meeting was devoid of group exercises. This pushes the meeting out of the clear cut workshop category towards public hearing. Lack of formality and loosely-structured poster session take away from hearing status. What is the happy medium? 


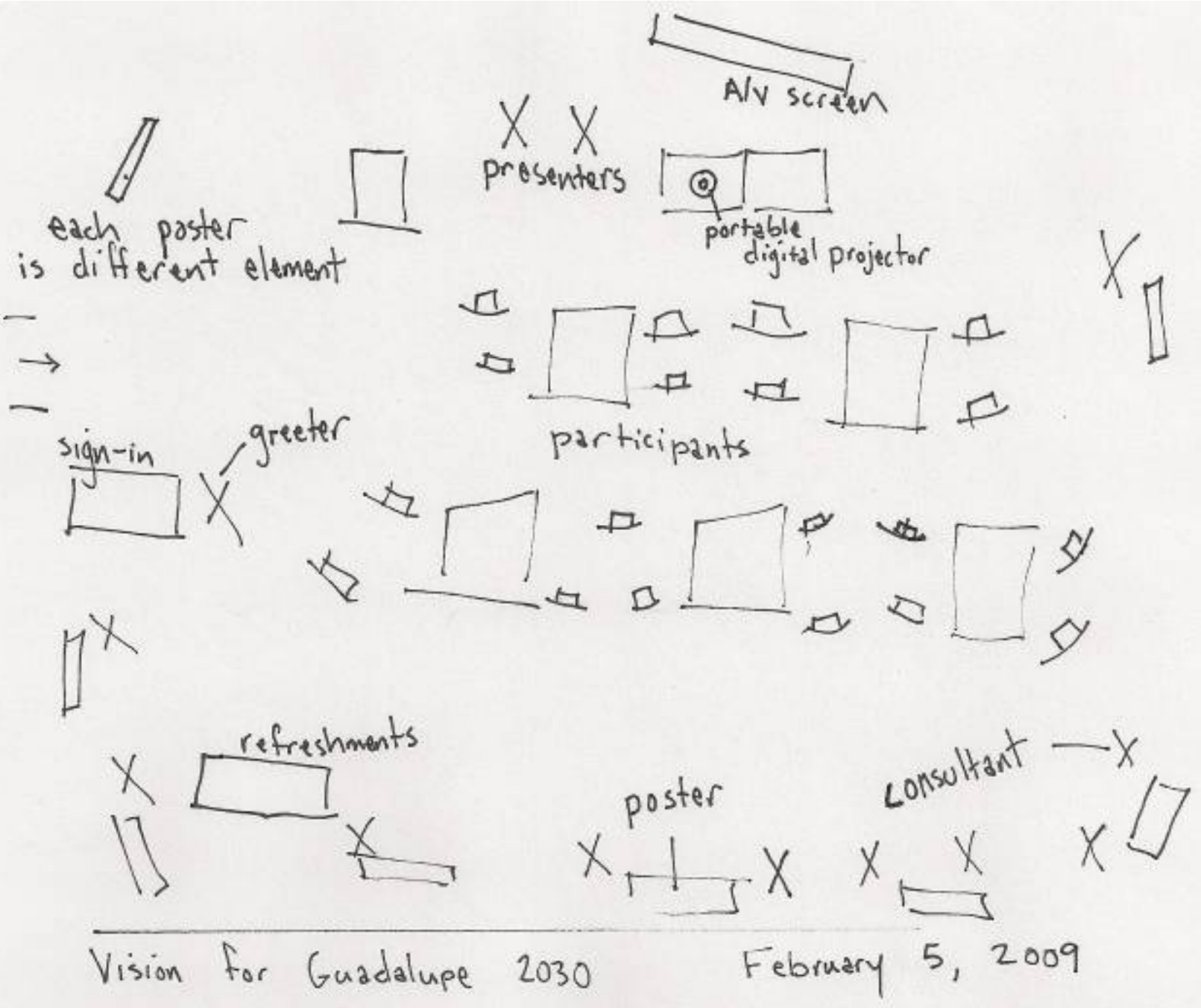

154 


\section{Case Study \#W5}

\begin{tabular}{|c|c|}
\hline \multicolumn{2}{|l|}{ General data } \\
\hline event title & $\begin{array}{l}\text { Vision for Guadalupe } 2030 \\
\text { Community Meeting (4 of } 5 \text { ) }\end{array}$ \\
\hline methodology & Public Workshop Series \\
\hline location & $\begin{array}{l}\text { Senior Center } \\
4545 \text { 10th Street } \\
\text { Guadalupe, CA } 93434\end{array}$ \\
\hline date and time & $\begin{array}{l}02 / 26 / 2009 \\
6: 30 \mathrm{pm}\end{array}$ \\
\hline $\begin{array}{l}\text { mediator(s) } \\
\text { (number of } \\
\text { presenters) }\end{array}$ & $\begin{array}{l}\text { California Polytechnic State University } \\
\text { City and Regional Planning (CRP) } \\
3 \text { presenters }\end{array}$ \\
\hline event duration & 2 hours \\
\hline attendance & $\begin{array}{l}15 \text { public } \\
\text { Mayor } \\
13 \text { Cal Poly }\end{array}$ \\
\hline early departures & 3 public \\
\hline late arrivals & 0 \\
\hline weather & 60 degrees, clear \\
\hline members & Mayor Lupe Alvarez \\
\hline
\end{tabular}


Meeting Characteristics

\begin{tabular}{|c|c|c|}
\hline $\begin{array}{l}\text { purpose/focus of } \\
\text { meeting }\end{array}$ & \multicolumn{2}{|c|}{$\begin{array}{l}\text { Present three growth alternatives based on goals and objectives from } \\
\text { previous meeting and projections. Facilitate community discussion } \\
\text { about which scenario is best for Guadalupe: Existing Trends, } \\
\text { Moderate Growth or Comprehensive Growth. }\end{array}$} \\
\hline $\begin{array}{l}\text { level of dialogue } \\
\text { staff to public } \\
\text { public to public }\end{array}$ & \multicolumn{2}{|c|}{$\begin{array}{l}\text { Meeting is mix of one way communication and breakout tables. } \\
\text { Presentation at beginning established three different choices for small } \\
\text { groups to consider. Each group discussed merits of varying } \\
\text { approaches to growth using face to face interaction at tables. One } \\
\text { member from each group reported back to whole room on what was } \\
\text { discussed. }\end{array}$} \\
\hline $\begin{array}{l}\text { speaker duration } \\
\text { staff vs. public }\end{array}$ & $\begin{array}{l}\text { 24. Presentation: Alternative Futures }(35 \\
\text { min) } \\
\text { 25. Breakout Tables ( } 45 \mathrm{~min}) \\
\text { 26. Group Member Presentations ( } 15 \mathrm{~min}) \\
\text { 27. Wrap-up ( } 15 \mathrm{~min})\end{array}$ & $\begin{array}{l}\text { Cal Poly: } 45 \% \\
\text { Public: } 55 \%\end{array}$ \\
\hline $\begin{array}{l}\text { visualization tools } \\
\text { maps, posters, } \\
\text { digital, } \\
\text { pamphlet }\end{array}$ & \multicolumn{2}{|c|}{$\begin{array}{l}\text { Portable digital projector, PPT, aerial photos and maps on boards, } \\
\text { Google SketchUp models of each growth scenario (in PPT and color } \\
\text { prints at tables), pens. SketchUp models demonstrated potential } \\
\text { massing downtown with different levels of density. }\end{array}$} \\
\hline structure & \multicolumn{2}{|c|}{$\begin{array}{l}\text { Began as formal presentation from Cal Poly representatives designed } \\
\text { to educate public about three plausible alternatives. Participants then } \\
\text { had an opportunity to discuss what was presented at group tables. All } \\
\text { groups selected one of the alternatives or a hybrid approach and } \\
\text { reported back to the larger audience. }\end{array}$} \\
\hline setting & \multicolumn{2}{|c|}{$\begin{array}{l}\text { Bright and clean community room with large tables. Seats arranged } \\
\text { around tables to facilitate discussion among participants. Projector } \\
\text { and screen to one side of the room. Participants had to rearrange } \\
\text { seats to face audiovisual screen during presentation. Sign in sheet on } \\
\text { reception table at entrance and refreshment table in back of room. }\end{array}$} \\
\hline $\begin{array}{l}\text { stage in planning } \\
\text { process } \\
\left(1^{\text {st }}, 2^{\text {nd }}, 3^{\text {rd }}\right. \\
\text { meeting })\end{array}$ & \multicolumn{2}{|c|}{$\begin{array}{l}\text { Fourth meeting in five meeting series. Voting stage on alternative } \\
\text { growth targets for Guadalupe } 2030 \text { community plan. }\end{array}$} \\
\hline $\begin{array}{l}\text { method of } \\
\text { interaction }\end{array}$ & \multicolumn{2}{|l|}{ Oratory/listener, breakout table dialogue } \\
\hline $\begin{array}{l}\text { public notification } \\
\text { method }\end{array}$ & \multicolumn{2}{|c|}{ Flyers handed out at public schools. Posted on City's website. } \\
\hline
\end{tabular}




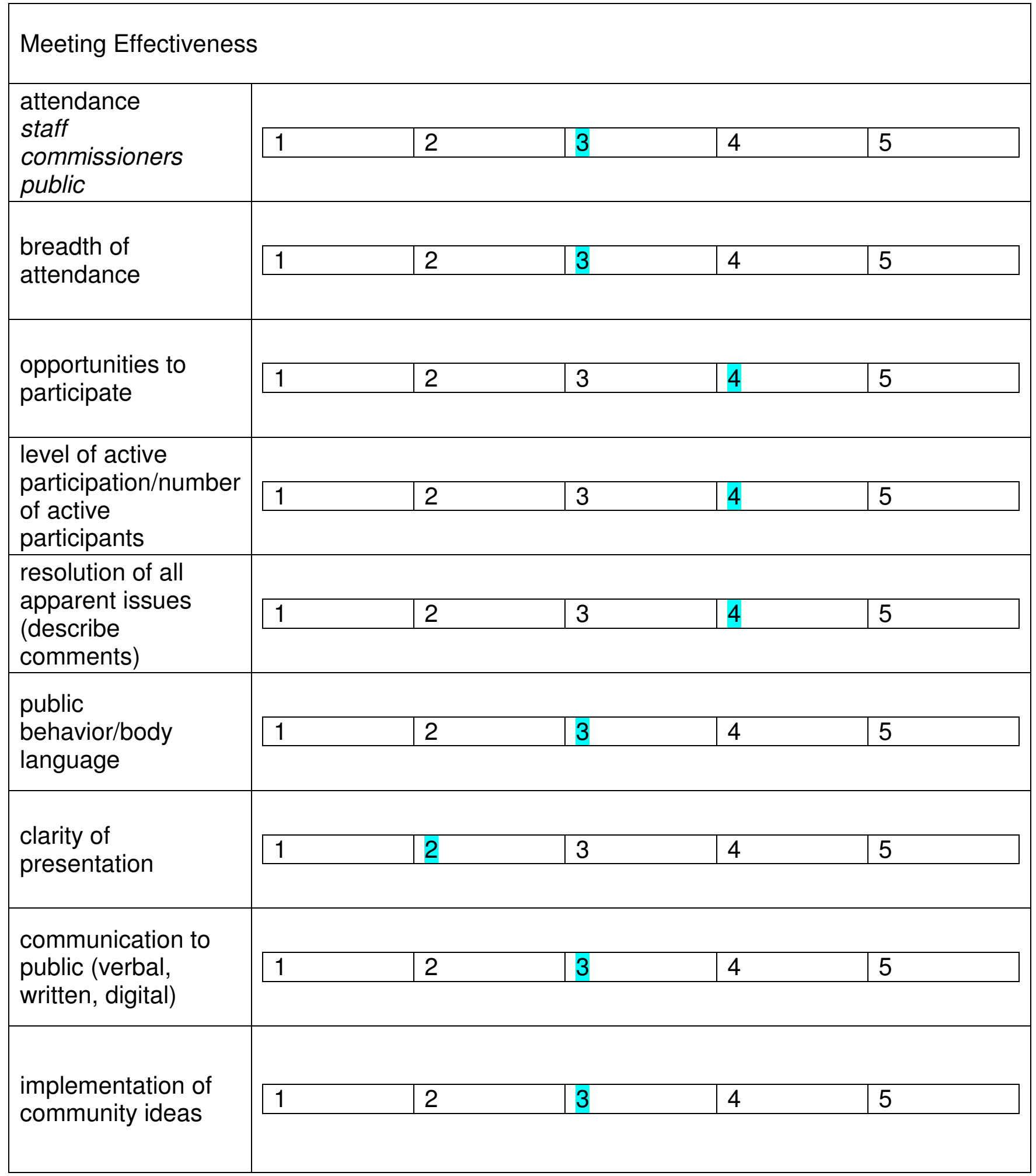


Further Observations

The most effective visualization tools were three dimensional massing models created in Google SketchUp. Concepts such as density and building height do not resonate as well in the absence of tangible images. The models helped people grasp exactly what some of the draft polices actually mean in the context of downtown Guadalupe. One drawback was that models did not have any more shape than simple boxes. The addition of some building features - especially on existing buildings - may have helped residents identify with the visual representations more.

Statistics and tables had the least impact on participants. The presentation relied heavily on projections and data tables to quantify growth for each alternative. It was apparent from body language and lack of questions from the audience about these numbers that the message did not come across.

The Mayor was once again present at the meeting, and used the opportunity to question some of the information presented. He wanted to make it clear that the alternatives suggested by Cal Poly were only aspirations, and that there wasn't enough financing to support some of the concepts being discussed.

The meeting seemed to focus more on Downtown strategies more than previous meetings. Perhaps this was because the massing study only modeled Downtown.

All tables arrived at the same conclusion (consensus)! Moderate Growth was preferred over other alternatives. This seemed likely from the outset because it is the common sense choice. For a town like Guadalupe, where growth is stagnant and diminished from previous years, moderate growth seems most viable. Not may people will support comprehensive growth since it is a drastic change.

Flow charts were helpful to catch up participants that had not attended previous meetings.

Even though the identified focus of the meeting was discussion about alternatives, the conversations at breakout tables drifted towards community desires. Each table had a facilitator, and rather than stifle conversation, they went with it. It seems that many community members wanted to put there concerns about Guadalupe on the table. This is what people are most familiar with and where passion lies. It is up to the facilitator to guide discussion, but an important crossroads that each facilitator had to face was when to try and keep comments on track or when to let dialogue continue. The risk of too much facilitating is silence from participants! 


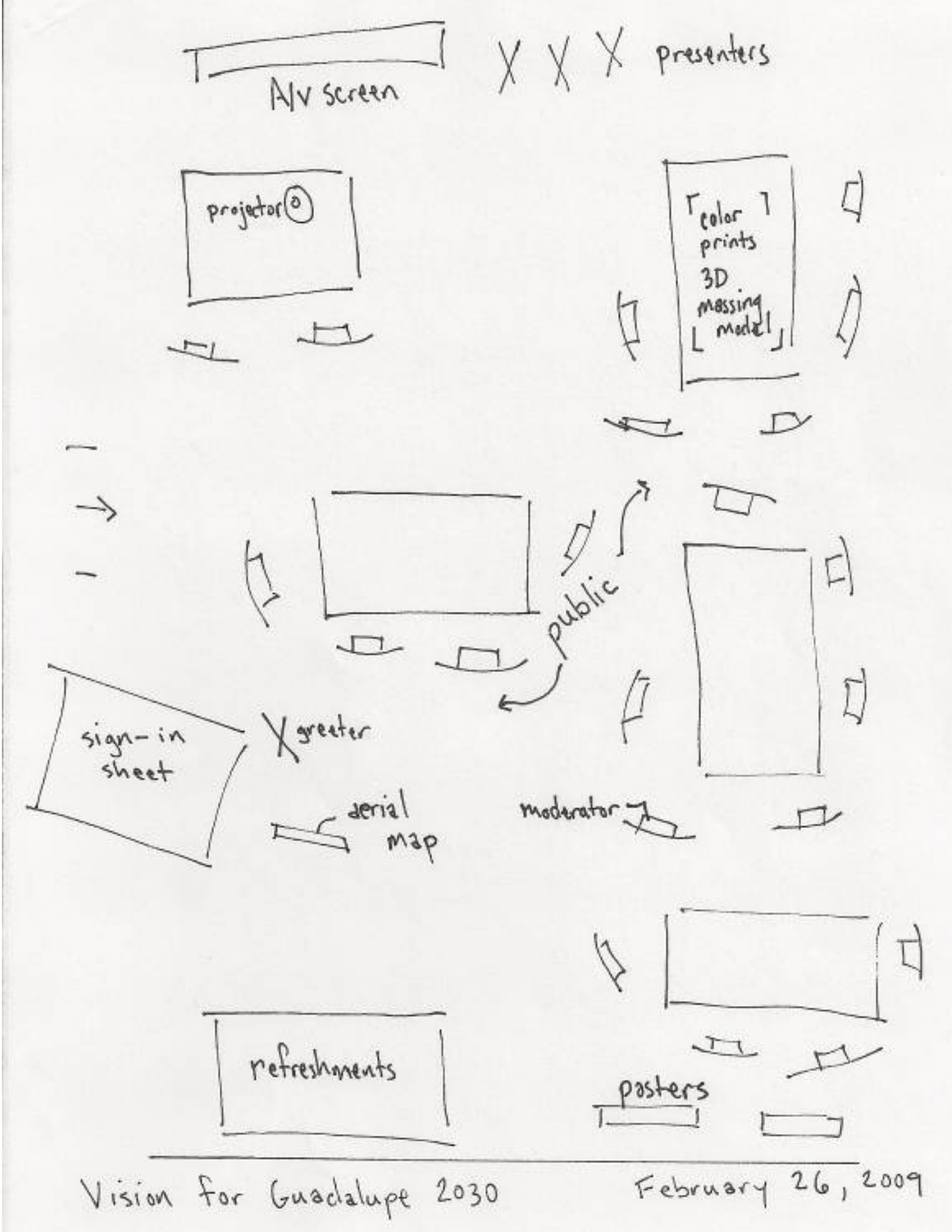

159 
Case Study \#H4

\begin{tabular}{|c|c|}
\hline \multicolumn{2}{|l|}{ General data } \\
\hline event title & $\begin{array}{l}\text { Vision for Guadalupe } 2030 \\
\text { Community Meeting ( } 5 \text { of } 5 \text { ) }\end{array}$ \\
\hline methodology & Public Workshop Series \\
\hline location & $\begin{array}{l}\text { Senior Center } \\
4545 \text { 10th Street } \\
\text { Guadalupe, CA } 93434\end{array}$ \\
\hline date and time & $\begin{array}{l}03 / 12 / 2009 \\
6: 30 \mathrm{pm}\end{array}$ \\
\hline $\begin{array}{l}\text { mediator(s) } \\
\text { (number of } \\
\text { presenters) }\end{array}$ & $\begin{array}{l}\text { California Polytechnic State University } \\
\text { City and Regional Planning (CRP) } \\
4 \text { presenters }\end{array}$ \\
\hline event duration & 2 hours \\
\hline attendance & $\begin{array}{l}10 \text { public } \\
\text { Mayor } \\
12 \text { Cal Poly }\end{array}$ \\
\hline early departures & 2 public \\
\hline late arrivals & 1 public \\
\hline weather & 55 degrees, clear \\
\hline members & $\begin{array}{l}\text { Mayor Lupe Alvarez } \\
\text { Planning Commissioner }\end{array}$ \\
\hline
\end{tabular}




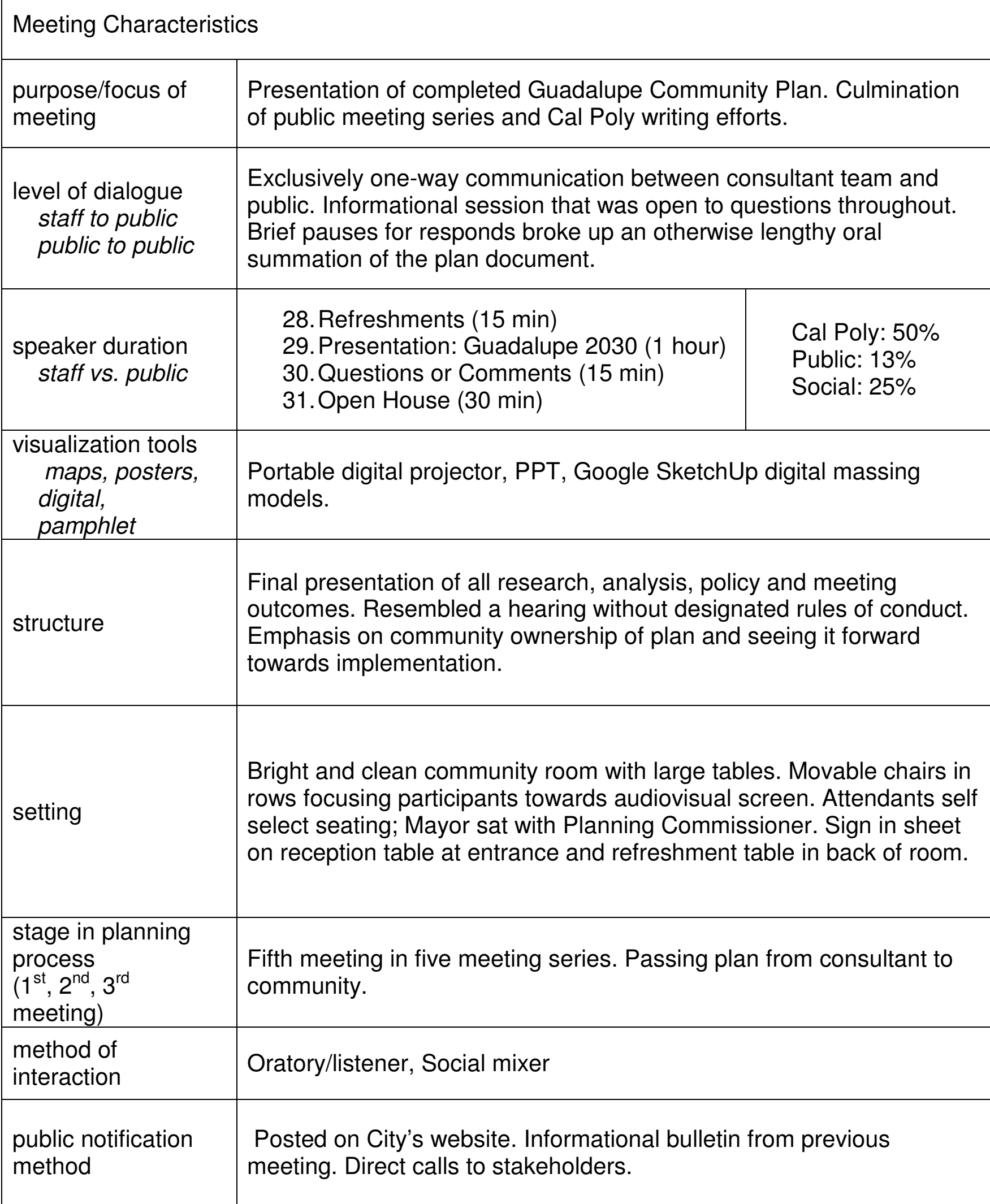




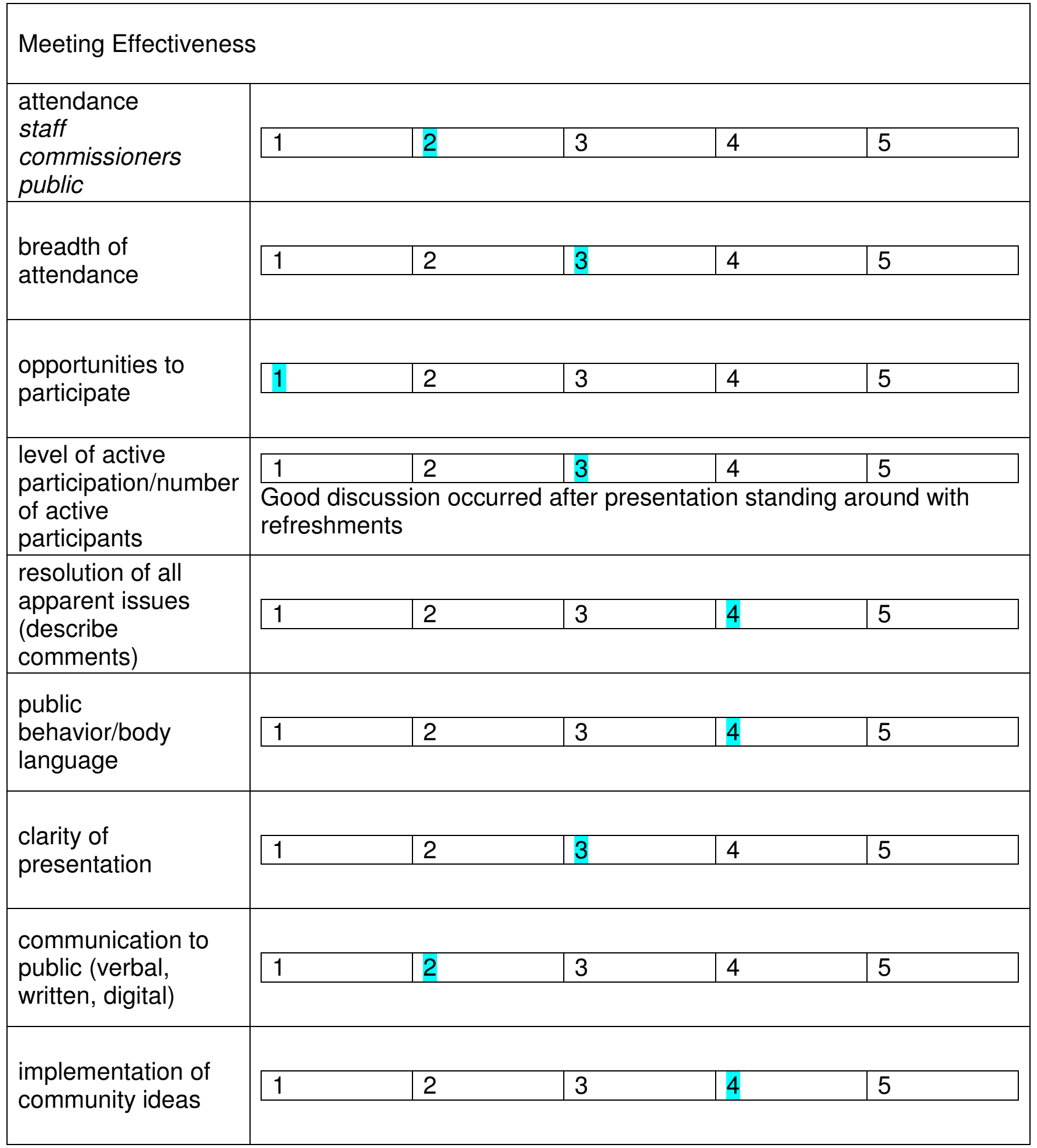


Further Observations

Each new meeting was a step down Arnstein's ladder away from citizen control.

Presentations became increasingly detailed and participants assumed a more passive role. Involving people in the early stages is easier because topics are general and conceptual. Is this inevitable as ideas transition into policy statements or tangible design?

Consultants placed considerable emphasis on reiterating the community-based nature of the project. Despite apparent complexity - goals, objectives, policies, programs - plan originates in public sentiment.

Few repeat attendees but decent mix of representatives from different sectors of Guadalupe's town fabric. Stakeholders present at various times during five meeting series: Guadalupe residents (all cohorts), Mayor, advisory body members (Planning Commission, City Council), Peoples Self-Help affordable housing developer, Community Plan consultant team - Cal Poly, Guadalupe planning staff - Rincon Consulting, Planning students, City Manager

Meetings were successful, yet could have reached a larger demographic. They were always held at a City building in a community room after work, with same basic refreshments. Other ideas: Hold a meeting at a school gymnasium during the day, on a weekend in a Park facility, or even organize a "screening" of the plan in a local theatre.

The act of gathering is a key variable of effective participation. Managing expectations by framing meeting title: workshop implies gathering to work on something together, hearing implies listening to something, usually an action that may affect you.

This element may be lost in technology. A person has limited comprehension of a sense of "gathering" from a number on a webinar that indicates 500 participants.

Overall this was a successful participation effort that achieved genuine participation early in the planning process. As the project drew closer to the end product, participation shifted away from interaction towards reaction. Questions changed from "How do you feel" to "How do you want to grow" to "Did we get this right". 


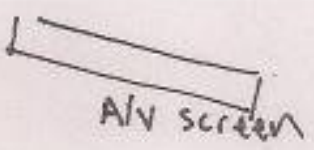

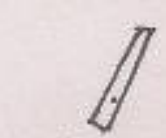

each poster is different element

-

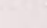

$-$ $\underset{\text { presenters }}{X} \underset{X}{X}$
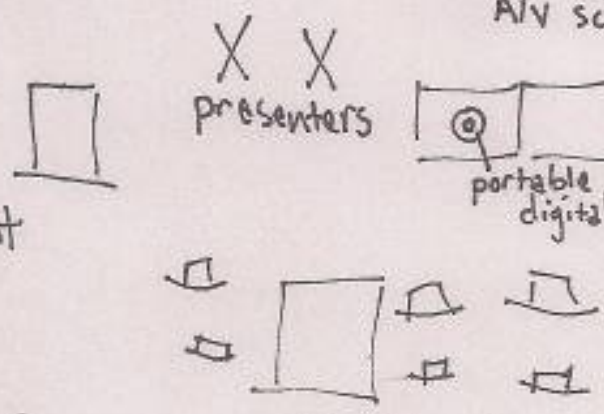

participants

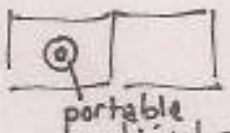
digital projector

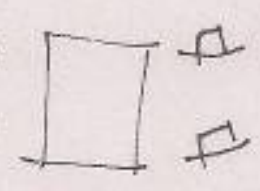

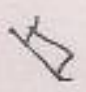

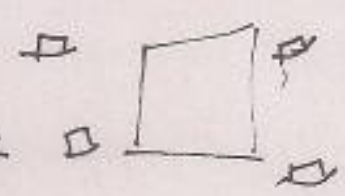

refreshments

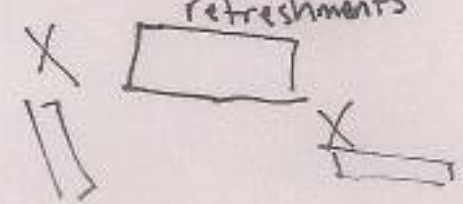

poster

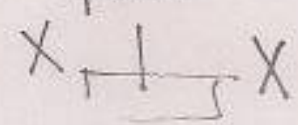

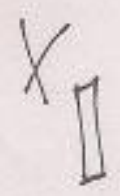

Vision for Guadalupe 2030

March 12, 2009 Senior Center

164 


\section{Case Study \# H5}

\begin{tabular}{|c|c|}
\hline \multicolumn{2}{|l|}{ General data } \\
\hline event title & Budget Hearings - FY 2009-2010 \\
\hline methodology & Public Hearing \\
\hline location & County Government Offices \\
\hline date and time & $\begin{array}{l}06 / 15 / 09 \\
9: 00 \mathrm{am}\end{array}$ \\
\hline $\begin{array}{l}\text { mediator(s) } \\
\text { (number of } \\
\text { presenters) }\end{array}$ & $\begin{array}{l}\text { Bruce Gibson, Chairperson } \\
\text { Jim Grand, Interim CAO }\end{array}$ \\
\hline event duration & 6 hours \\
\hline attendance & 50 audience, 5 Supervisors, 5 staff \\
\hline early departures & 2 \\
\hline late arrivals & $\begin{array}{l}18 \text { public } \\
\text { Media arrived at } 10 \mathrm{am}\end{array}$ \\
\hline weather & 68 degrees, sunny \\
\hline members & $\begin{array}{l}\text { Board: Bruce Gibson, K.H. "Katchao" Achjan, Adam Hill, James } \\
\text { Patterson, Frank Mecham } \\
\text { Staff: County Counsel, Clerk of the Board, two presenters }\end{array}$ \\
\hline
\end{tabular}




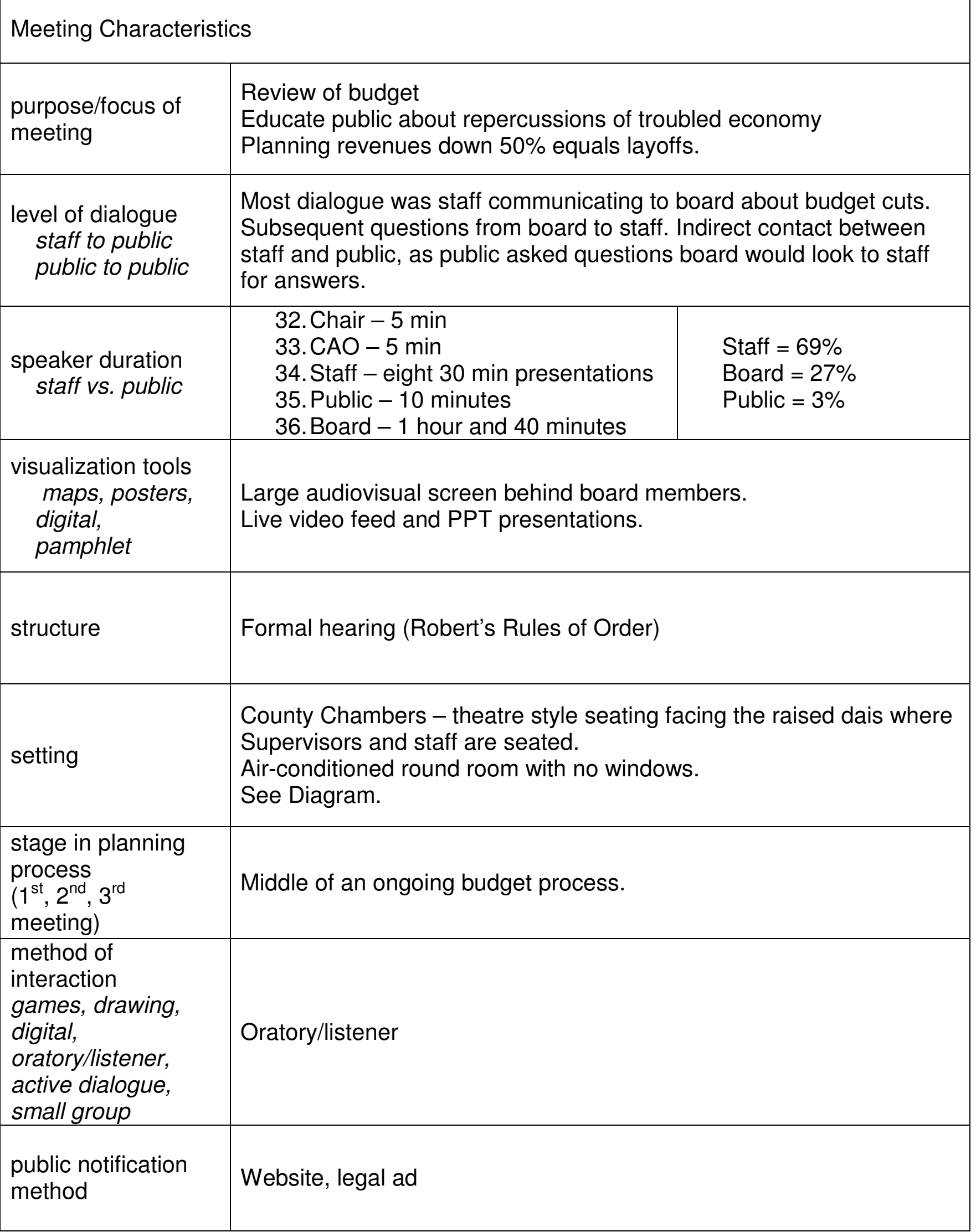




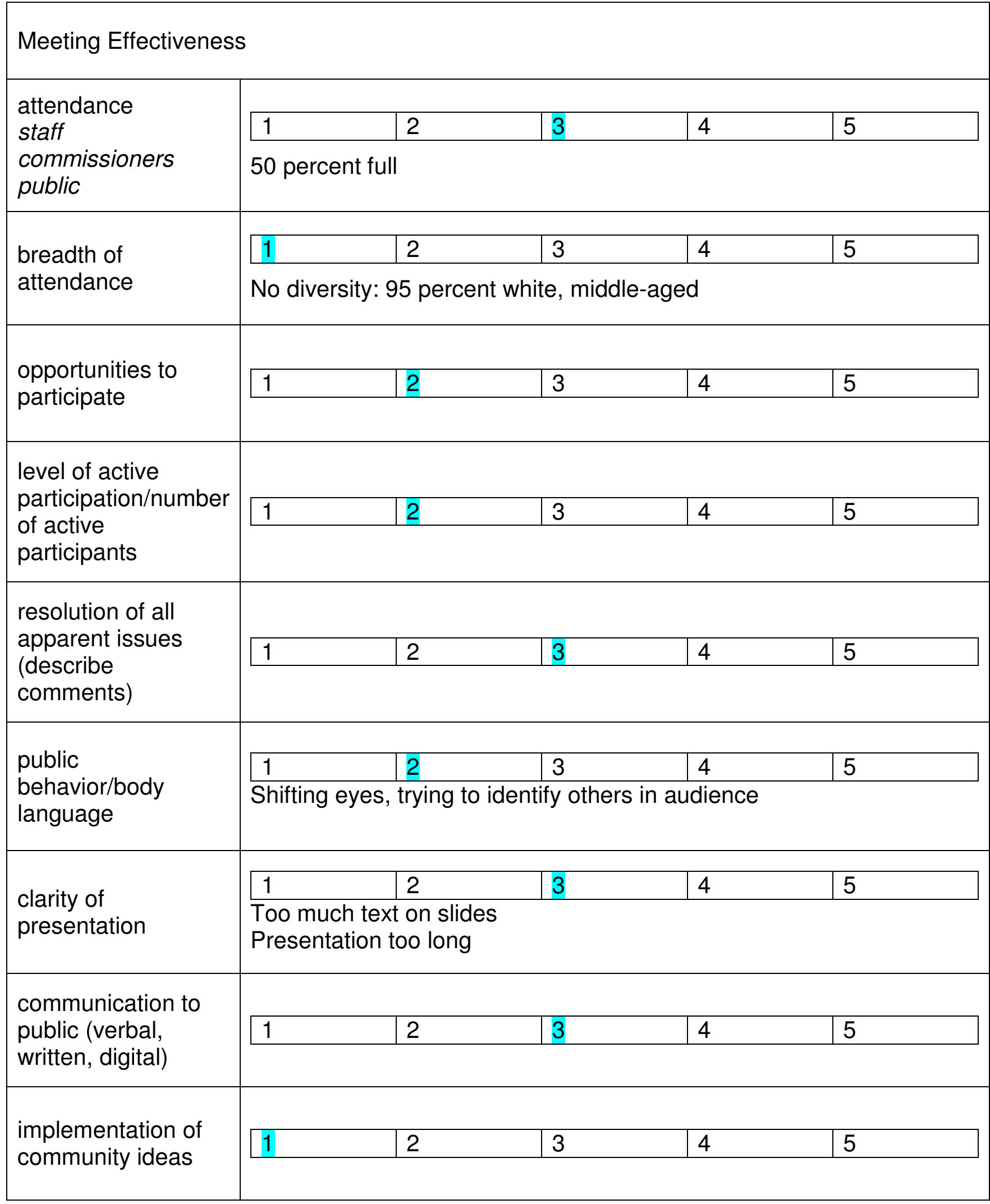


Further Observations

Supervisors are constantly looking at computer screens in desk instead of making eye contact with the public or staff.

How many audience members are required to be at the hearing? Greetings among people in audience and visual recognition imply that they come to Supervisor hearings regularly.

Mostly suits, ties, and dresses in audience.

Meeting designed to be solely education: inform the board about budget decisions, inform the public about budget implications

-No input from public on whom or where to cut (did this happen in an earlier meeting?)

Meeting appears to be happening towards the end of the process. Staff and the board are telling people what decisions are happening. Communication is a one-way flow.

One PowerPoint slide is light hearted! It is meant to garner a few laughs but the board remains resolute.

Audience is quiet. All you can hear is hushed whispers and the occasional disruptive sound of a cell phone ringing.

The first hour is dominated by staff presentations with the odd clarifying question or comment from a board member. After 50 minutes the public gets there chance!

-Resident \#1: Prepared statement critical of budget cuts

-Resident \#2 (Host of government watchdog radio-show): Adversarial comments about how the budget is not business friendly

-Resident \#3 (Representative from agricultural community): Prepared statement about inequality of giving Planning department a small increase.

-No more public input

Audiovisual can be very helpful, but too much automation can be distracting as well. Each resident was given three minutes to speak and a giant screen with a flashing clock counted down the time. The font changed from green, to yellow, to red as time ticked down. This was visually distracting to public speakers and also sets the tone that the board is placating residents.

During staff presentations, department heads took turns reacting to proposed budget cuts. Ironically, discussion occurred about impacts to the public, yet residents were given little chance to respond and it did not seem that residents were involved in the initial decisions. The standard answer from staff was that, "things will take longer". 


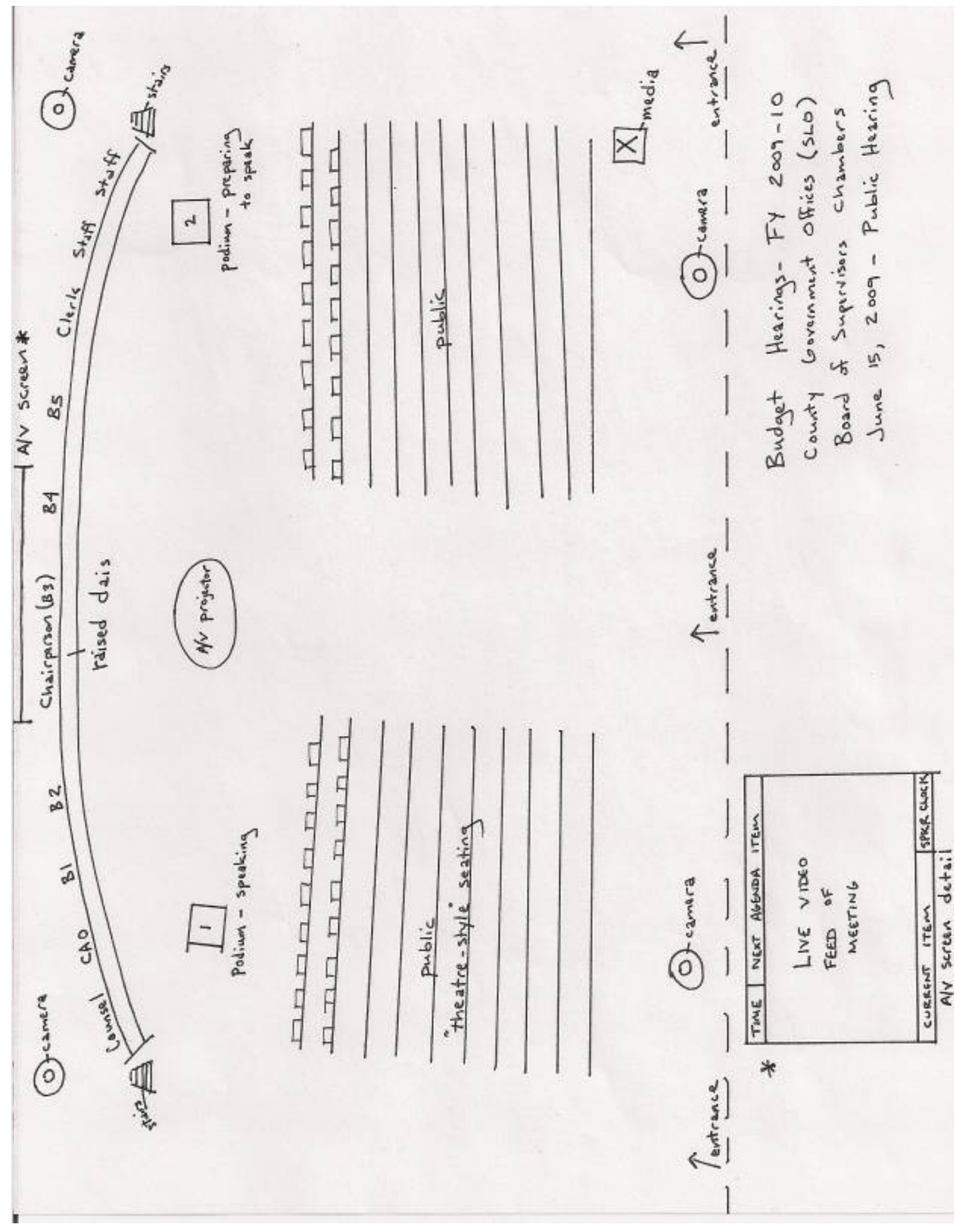


Case Study \#H6

\begin{tabular}{|c|c|}
\hline \multicolumn{2}{|l|}{ General data } \\
\hline event title & $\begin{array}{l}\text { Special Joint Meeting: Atascadero City Council \& Planning } \\
\text { Commission } \\
\text { Workshop on } 2009 \text { Housing Element Update }\end{array}$ \\
\hline methodology & Advertised as workshop, but really public hearing \\
\hline location & $\begin{array}{l}\text { City Hall, Council Chambers } \\
6907 \text { El Camino Real } \\
\text { Atascadero, CA } 93423\end{array}$ \\
\hline date and time & $\begin{array}{l}\text { 06/16/2009 } \\
\text { 7:00 pm }\end{array}$ \\
\hline $\begin{array}{l}\text { mediator(s) } \\
\text { (number of } \\
\text { presenters) }\end{array}$ & Lisa Wise Consulting, Inc. \\
\hline event duration & 3 hours \\
\hline attendance & 10 public, 10 advisory body, 3 staff \\
\hline early departures & 1 public \\
\hline late arrivals & 1 public \\
\hline weather & 70 degrees, clear \\
\hline members & $\begin{array}{l}\text { City Council } \\
\text { Planning Commission }\end{array}$ \\
\hline
\end{tabular}




\begin{tabular}{|c|c|c|}
\hline $\begin{array}{l}\text { purpose/focus of } \\
\text { meeting }\end{array}$ & \multicolumn{2}{|c|}{$\begin{array}{l}\text { Special joint meeting for City Council and Planning Commission to } \\
\text { receive information regarding the } 2009 \text { Housing Element, hear public } \\
\text { testimony, and provide feedback to staff. }\end{array}$} \\
\hline $\begin{array}{l}\text { level of dialogue } \\
\text { staff to public } \\
\text { public to public }\end{array}$ & \multicolumn{2}{|c|}{$\begin{array}{l}\text { Communication predominately between consultant and } \\
\text { Council/Commissioners. Dialogue was prepared ahead of time and } \\
\text { conveyed to Council through PPT. Council asked questions of } \\
\text { consultant and engaged with residents during public comment period } \\
\text { (5 minutes per speaker). }\end{array}$} \\
\hline $\begin{array}{l}\text { speaker duration } \\
\text { staff vs. public }\end{array}$ & $\begin{array}{l}\text { 37. City Manager ( } 5 \text { min) } \\
\text { 38. Consultant ( } 30 \text { minutes) } \\
\text { 39. Council and Commissioners: } \\
\text { Questions and discussion ( } 60 \\
\text { min) } \\
\text { 40. Public Comment ( } 30 \mathrm{~min}) \\
\text { 41. Council wrap-up ( } 15 \mathrm{~min}) \\
\text { 42. Planning Staff ( } 5 \mathrm{~min})\end{array}$ & $\begin{array}{l}\text { Consultant: } 21 \% \\
\text { Staff: } 7 \% \\
\text { Council/Commissioners: } \\
52 \% \\
\text { Public: } 20 \%\end{array}$ \\
\hline $\begin{array}{l}\text { visualization tools } \\
\text { maps, posters, } \\
\text { digital, } \\
\text { pamphlet }\end{array}$ & \multicolumn{2}{|c|}{ PPT, audiovisual screen, agenda handouts for public and Council. } \\
\hline structure & \multicolumn{2}{|c|}{$\begin{array}{l}\text { Kick-off meeting for } 2009 \text { Housing Element Update. First half was } \\
\text { presentation followed by detailed question and answer period. } \\
\text { Questions from Council interrupted the presentation and often sent } \\
\text { discussion on tangent. }\end{array}$} \\
\hline setting & \multicolumn{2}{|c|}{$\begin{array}{l}\text { Council Chambers = old bowling alley! Rows of interlocking chairs } \\
\text { arranged lecture hall style. Clean bright room with everyone on same } \\
\text { level (no raised dais). Council and staff seated around large semicircle } \\
\text { dais facing seated community members. }\end{array}$} \\
\hline $\begin{array}{l}\text { stage in planning } \\
\text { process } \\
\left(1^{\text {st }}, 2^{\text {nd }}, 3^{\text {rd }}\right. \\
\text { meeting })\end{array}$ & \multicolumn{2}{|c|}{$\begin{array}{l}\text { First formal hearing in Housing Element update process. Consultant } \\
\text { noted that one on one } 30 \text {-minute meetings had been held with } \\
\text { stakeholders prior to the "workshop". }\end{array}$} \\
\hline $\begin{array}{l}\text { method of } \\
\text { interaction }\end{array}$ & \multicolumn{2}{|c|}{$\begin{array}{l}\text { Oratory/listener, question and answer. Meeting governed by Robert's } \\
\text { Rules of Order. }\end{array}$} \\
\hline $\begin{array}{l}\text { public notification } \\
\text { method }\end{array}$ & \multicolumn{2}{|l|}{ Website, legal ads, local newspaper } \\
\hline
\end{tabular}




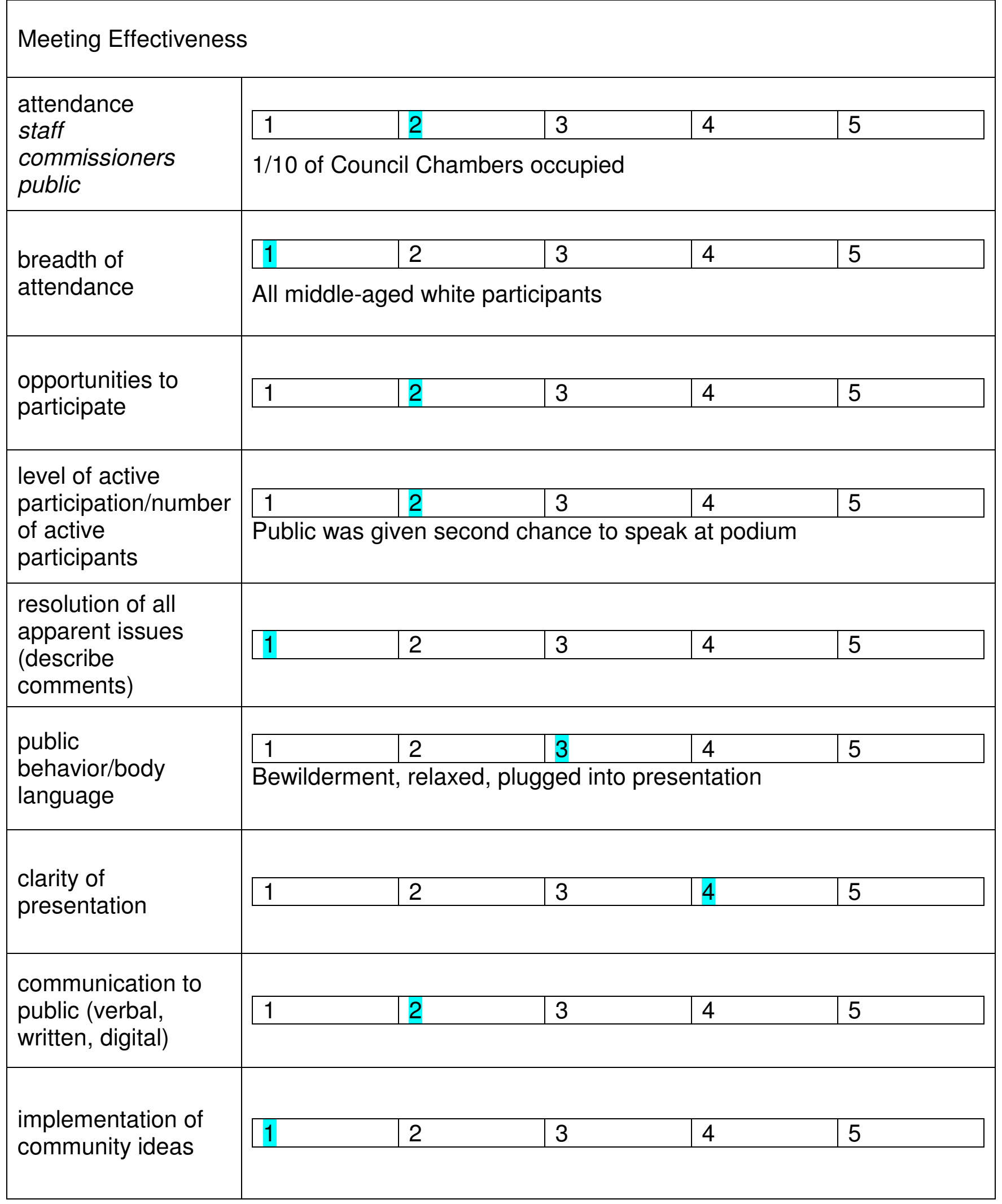


Further Observations

Even though the meeting was billed as a workshop, it was a clear departure from the loosely structured collaborative environment of Sanoff's workshop definitions. The pledge of allegiance was recited in customary fashion before the meeting, which established a formal tone at the outset. This is common practice for most hearings.

Presentation was good with clear graphics conveying the speaker's points. Council got stuck on the regional needs allocation for Atascadero, questioning the consultant extensively about the State requirement for affordable dwellings.

The consultant noted that one-on-one stakeholder meetings were conducted with public officials in City Hall, the business community, and non-profits. Each meeting was approximately 30 minutes each. A large section of the consultant PPT was devoted to identifying stakeholder concerns.

This was the first public hearing observed without a raised dais! This helps eliminate apparent differences in power. However, a large physical barrier (semi-circle dais about 3 feet tall) separated Council/Commission/Staff from public seated in theatre rows of quasimovable seats.

Council inquiries were mostly about technicalities of State requirements for local Housing Elements. Other comments - that were slightly adversarial - raised doubts about statistics being presented by the consultant.

When speaking about whether or not to strive for a "certified" housing element, one Council member inquired about what happens if we tell the State, "We ain't doing it!" Many Council members and Commissioners probed the consultant about the merits of certifying the Element. Discussion turned to what "counts" as a dwelling for the purposes of meeting State requirements.

At this point the meeting was going off-track. The consultant did not fill the roll of mediator, only presenter. The Chairperson did not effectively keep comments focused on overall Housing Element update project, and instead joined in tangential discussion about whether RHNA was fair or even desirable for the City of Atascadero.

Eventually, the presentation continued and a few Council questions elicited some interesting policy ideas from various Commissioners on how to increase affordable dwelling numbers:

-Amnesty program for illegal secondary dwelling units (no code enforcement if owners come in for permit)

-Use Community Development Block Grant funds to waive development impact fees for SDUs 
Joint session deliberation continued with comments from every Council member or Commissioner. In a public setting with all eyes on the dais, it is apparent that Council members feel compelled to speak up about something. It is almost as if they do not feel they are fulfilling their role unless they have some comments. This is good because the public gets a chance to be party to a transparent decision-making process that is happening before their eyes. The fault is that the public is passive in the discussion. Assuming a more voyeuristic role, participants have to sit idly by and wait for their timed opportunity to give input.

Unfortunately, often times this input is pre-prepared and unrelated to the focus of the meeting. The first person from the public to speak was adversarial in nature and concerned solely with his own project that was still working its way through a lengthy planning process. It happened to be an affordable housing project so the topic was somewhat on point. As his time at the podium progressed he became increasingly more agitated and started shaking his finger at the Planning Commissioners. He claimed they had "stonewalled" against developers bringing affordable projects forward. He ended with raised voice, flushed face, stating that the Planning Commission had a "personal vendetta" and loudly questioned "What about my projects?" The Chairperson (mayor) cut him off.

The remaining participants who commented were all developers as well. They had vested interests in the Housing Element policies. Instead of suggesting new alternatives, the second person to comment expressed concerns about the difficulty of building affordable housing projects with no soft money from the City. This was solid input from the community that should be addressed. The Council simply nodded and asked for the next speaker.

The third and fourth comments came from developers complaining about City fees and requirements for engineers to be certified. Public comment closed with the first developer back at the podium shaking his finger and telling certain members of the Planning Commission to "Beat it!"

This hearing was a classic example of what local governments contend is a workshop, but very far from the truth. Municipalities get stuck in the realm of Robert's Rules and forgo key elements that make a workshop true to form: people talking face to face in a small group environment with an absence of titles and power struggles. 


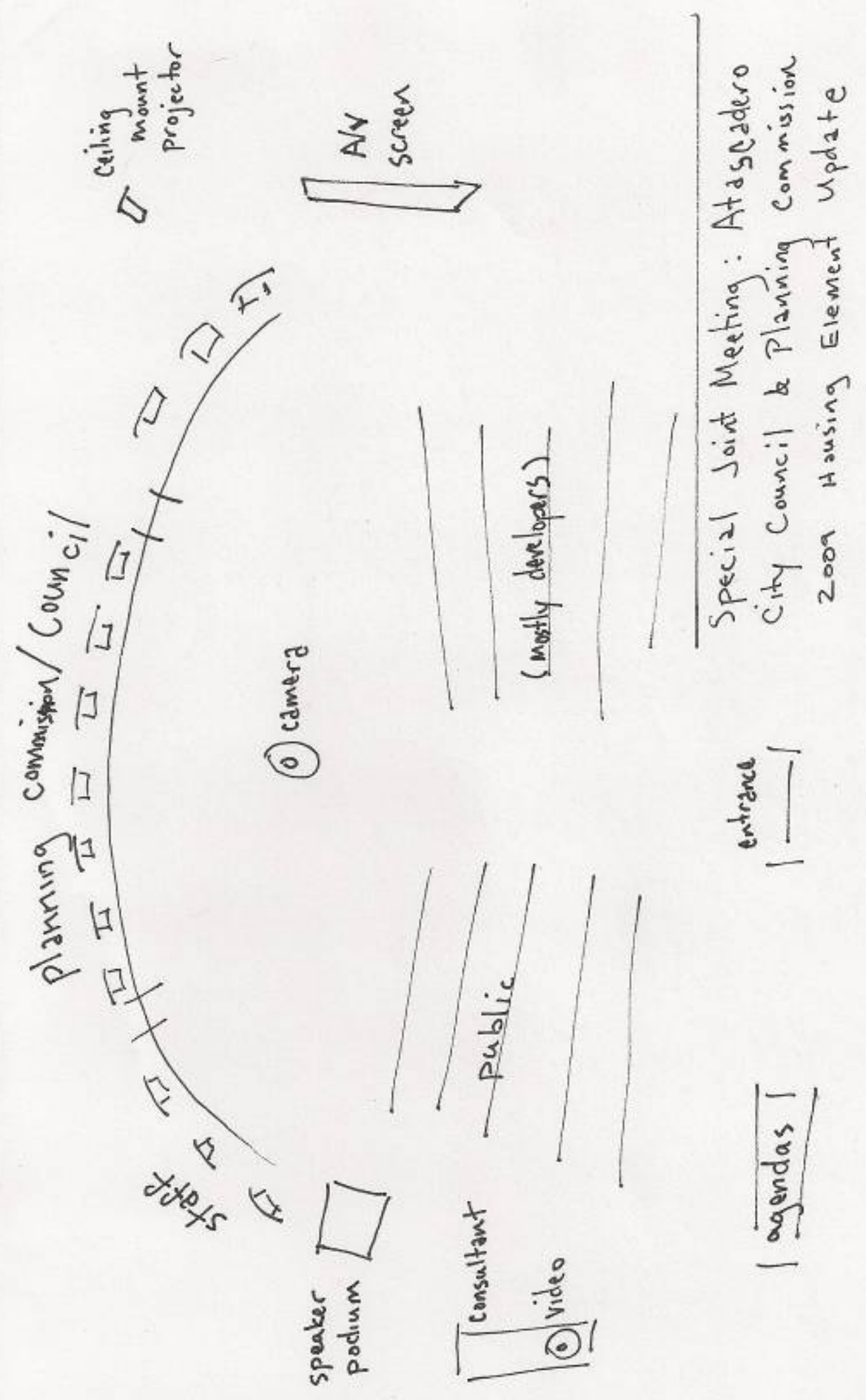




\section{Case Study \#W6}

\begin{tabular}{|c|c|}
\hline \multicolumn{2}{|l|}{ General data } \\
\hline event title & Preservation and Design Review Workshop \\
\hline methodology & Workshop/training \\
\hline location & $\begin{array}{l}\text { City/County Library Community Room } \\
995 \text { Palm Street } \\
\text { San Luis Obispo, CA } 93401\end{array}$ \\
\hline date and time & $\begin{array}{l}\text { 8/17/2009, 7:00 pm } \\
\text { 8/18/2009, 9:00 am }\end{array}$ \\
\hline $\begin{array}{l}\text { mediator(s) } \\
\text { (number of } \\
\text { presenters) }\end{array}$ & $\begin{array}{l}\text { Winter \& Company } \\
1265 \text { Yellow Pine Avenue } \\
\text { Boulder, Colorado } 80304\end{array}$ \\
\hline event duration & $\begin{array}{l}2 \text { part session, } 2 \text { hour evening presentation and } 4 \text {-hour } \\
\text { workshop/training the following day }\end{array}$ \\
\hline attendance & 5 public, 12 advisory body, 9 staff \\
\hline early departures & 1 staff \\
\hline late arrivals & 5 public \\
\hline weather & 72 degrees, clear \\
\hline members & $\begin{array}{l}\text { Architectural Review Commission } \\
\text { Cultural Heritage Committee }\end{array}$ \\
\hline
\end{tabular}




\begin{tabular}{|c|c|c|}
\hline $\begin{array}{l}\text { purpose/focus of } \\
\text { meeting }\end{array}$ & \multicolumn{2}{|c|}{$\begin{array}{l}\text { Provide participants an overview of historic preservation and ways to } \\
\text { implement it through design review. Educate regulators (not } \\
\text { consumers) how to identify key building features and design } \\
\text { principles. Help participants define historic district character. }\end{array}$} \\
\hline $\begin{array}{l}\text { level of dialogue } \\
\text { staff to public } \\
\text { public to public }\end{array}$ & \multicolumn{2}{|c|}{$\begin{array}{l}\text { Evening session is mostly speaker's first person accounts of historic } \\
\text { preservation efforts in Boulder, Colorado. On the second day dialogue } \\
\text { shifts from presenter/audience to small group discussion with group } \\
\text { member reports. }\end{array}$} \\
\hline $\begin{array}{l}\text { speaker duration } \\
\text { staff vs. public }\end{array}$ & $\begin{array}{l}\text { Evening } \\
\text { 43. Staff (5 min) } \\
\text { 44. Presenter (60 min) } \\
\text { 45. Member discussion (20 min) } \\
\text { 46. Public questions (15 min) } \\
\text { Daytime } \\
\text { 47. Mediator ( } 45 \mathrm{~min}) \\
\text { 48. Small Groups (140 min) } \\
\text { 49. Group Reports (20 min) } \\
\end{array}$ & $\begin{array}{l}\text { Consultant: } 34 \% \\
\text { Staff: } 2 \% \\
\text { Advisory Body } \\
\text { Members: } 6 \% \\
\text { Public: } 56 \%\end{array}$ \\
\hline $\begin{array}{l}\text { visualization tools } \\
\text { maps, posters, } \\
\text { digital }\end{array}$ & \multicolumn{2}{|c|}{$\begin{array}{l}\text { PPT, audiovisual screen, flipchart, group exercises (4), agenda } \\
\text { packets. }\end{array}$} \\
\hline structure & \multicolumn{2}{|c|}{$\begin{array}{l}\text { Extended workshop organized like a retreat for } \mathrm{CHC}, \mathrm{ARC} \text { and staff. } \\
\text { Out of town consultant hired to lead training about historic } \\
\text { preservation. Lecture provided education, and small group exercises } \\
\text { enabled application of principles being discussed. At the end of each } \\
\text { exercise one member from each group presented a brief description } \\
\text { of table discussion. }\end{array}$} \\
\hline setting & \multicolumn{2}{|c|}{$\begin{array}{l}\text { Library community room with tables set up diagonally creating rows. } \\
\text { Advisory body members and staff filled first two rows on either side of } \\
\text { screen. Each member had nameplate. Public seated in ancillary } \\
\text { location behind staff/members. } \\
\text { Following day tables were rearranged to create small groups. } \\
\text { Refreshments were in back corner (cookies, coffee, water). }\end{array}$} \\
\hline $\begin{array}{l}\text { stage in planning } \\
\text { process }\end{array}$ & \multicolumn{2}{|c|}{ Ongoing. Periodic training for advisory body members. } \\
\hline $\begin{array}{l}\text { method of } \\
\text { interaction }\end{array}$ & \multicolumn{2}{|c|}{ Oratory/listener, questions. Small group active dialogue, exercises. } \\
\hline $\begin{array}{l}\text { public notification } \\
\text { method }\end{array}$ & \multicolumn{2}{|l|}{ Website, press release, word of mouth. } \\
\hline
\end{tabular}




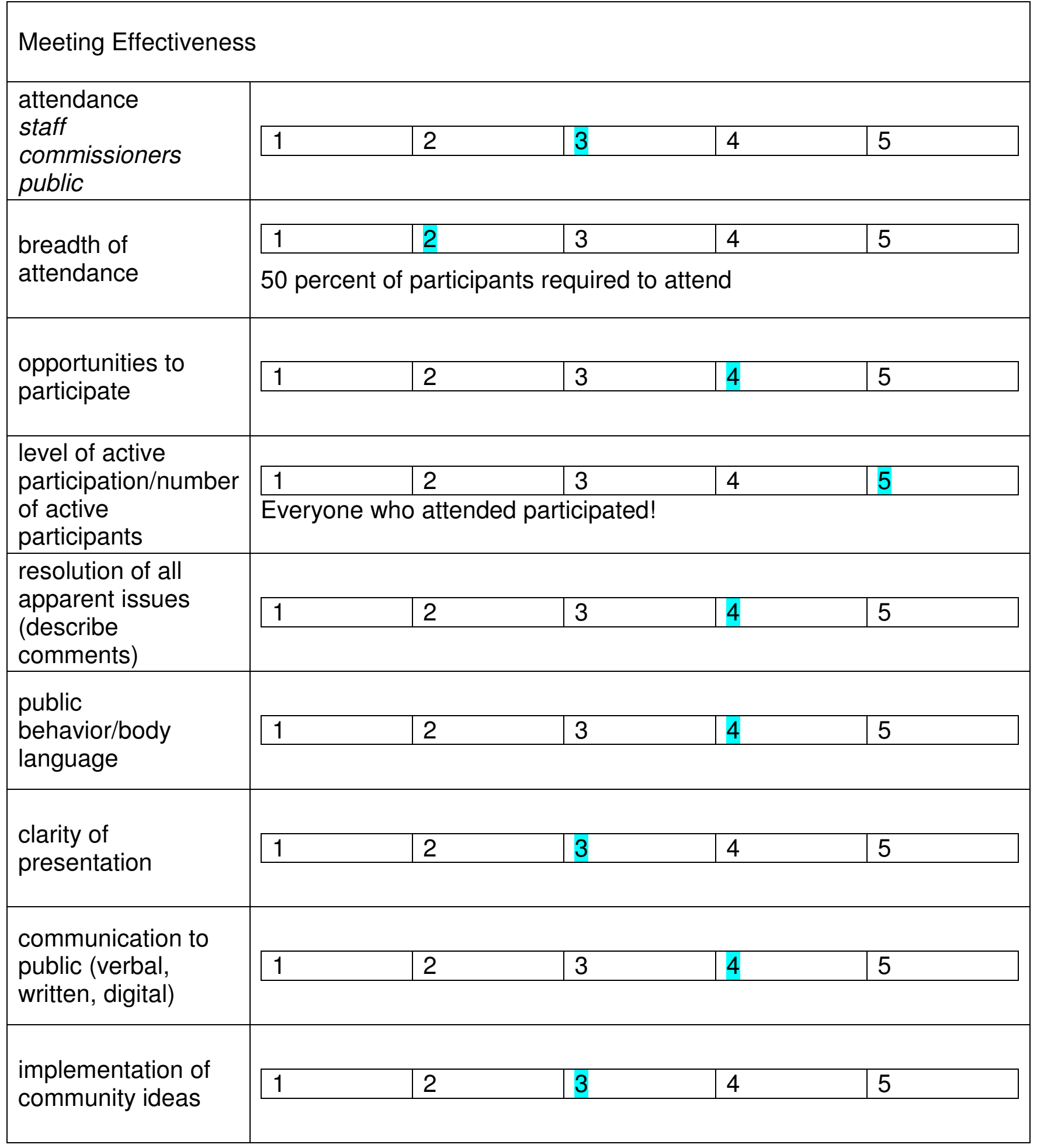


Further Observations

Preservation and Design Review workshop was open to the public, but really designed as $\mathrm{CHC}$ and ARC training. Members of public in attendance were stakeholders "in the business" of historic preservation (architects, designers, historians).

Subject matter, however, was universal. Presentation was largely "lessons learned" by consultant from Boulder, Colorado. Exercises were not contextual to San Luis Obispo area.

Group exercises incited focused discussion about architecture and design. Photos were printed on $11 \times 17$ paper depicting "then and now" snapshots of a particular building.

Discussion started with clarification of group assignment and inspection of photographs. People were uncertain about exactly what was portrayed in historic snapshots. Groups then identified key building features both current and historic to help guide a restoration plan. Subsequent exercises expanded the group's focus to whole blocks or historic districts.

A distinct element of this workshop is focused discussion. Participants did not offer personal stories or voice concerns. There was limited opportunity for opinions or debate. Primary interaction centered on the task given to the group. A communal assignment neutralizes preconceived notions associated with class, standing, or power. Dominators in the group arise from knowledge of the subject matter instead of job description.

No note-taker assigned yet each group had someone who self-selected. Space provided on exercise sheets for listing ideas. Almost all contributions offered from participants were written down.

Small groups had not introductions at tables. Each group went right into problem-solving without establishing identities. It was evident that everyone at the table was familiar with historic preservation and architecture when words like "quoin" and "cornice" were tossed around. Those that showed up to the workshop had vested interests or background in the subject matter. Are these the people that benefit most from an introductory workshop on historic preservation? Are they the only residents who care to participate?

Brief overview of key training points on treatment of historic buildings:

1. Preserve if intact; 2 . Repair if damaged; 3 . Replace in kind if beyond repair;

4. Replace with new interpretation if needed; 5 . Compatible alteration if needed

At the end of the whole training/workshop, participants were satisfied. One gentleman made a point to state, "great workshop" to anyone near him. All participants clapped and thanked. 


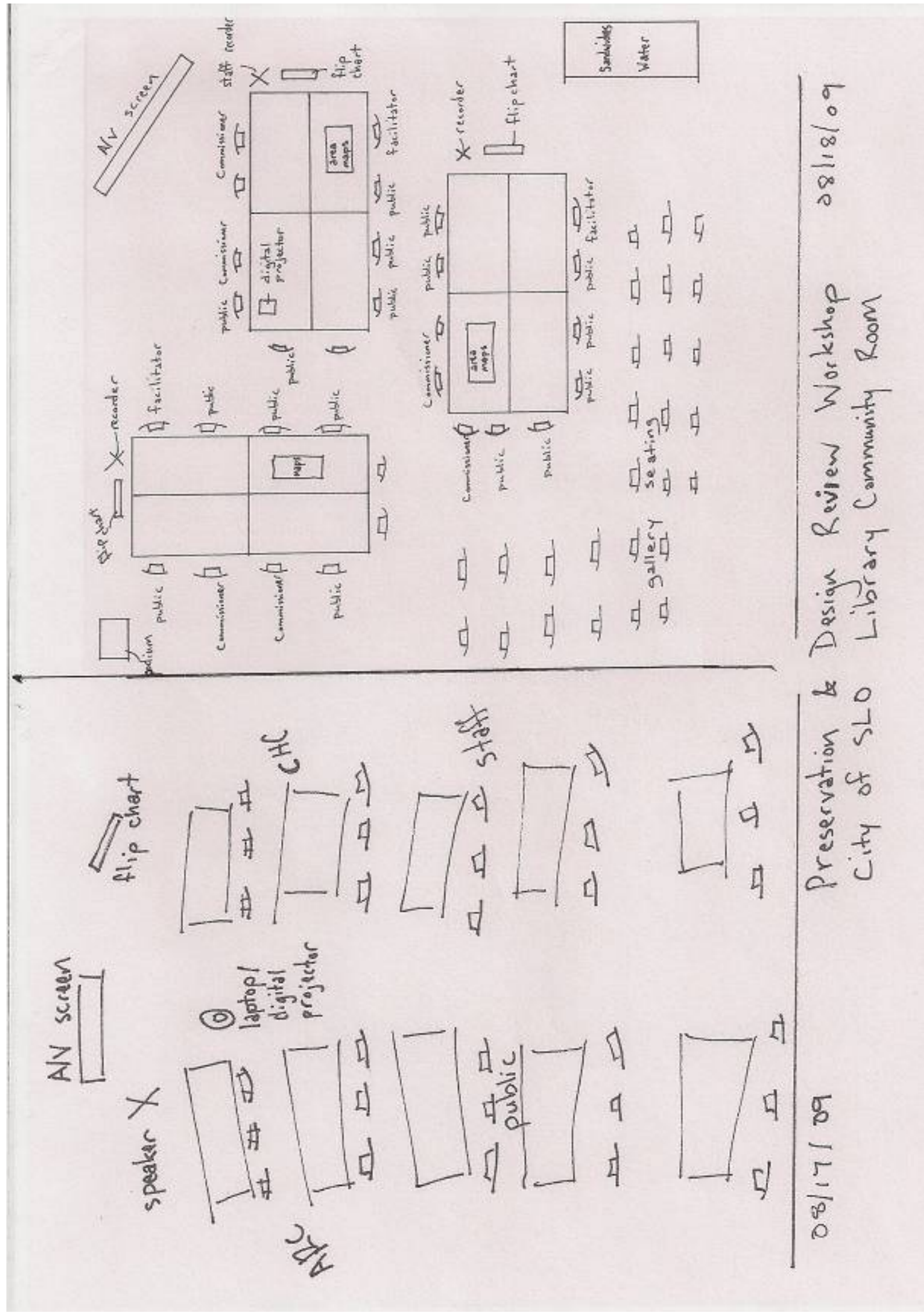




\section{Case Study \#W7}

\begin{tabular}{|c|c|}
\hline \multicolumn{2}{|l|}{ General data } \\
\hline event title & 2009 Housing Element Workshop \\
\hline methodology & Workshop? \\
\hline location & $\begin{array}{l}\text { Ludwick Community Room } \\
864 \text { Santa Rosa St } \\
\text { San Luis Obispo, CA } 93401\end{array}$ \\
\hline date and time & $\begin{array}{l}\text { 09/10/2009 } \\
6: 00 \mathrm{pm}\end{array}$ \\
\hline $\begin{array}{l}\text { mediator(s) } \\
\text { (number of } \\
\text { presenters) }\end{array}$ & $\begin{array}{l}2 \text { City staff } \\
\text { Kim Murry, Deputy Director, Long Range } \\
\text { Jeff Hook, Senior Planner }\end{array}$ \\
\hline event duration & 3 hours \\
\hline attendance & 3 public, 4 staff \\
\hline early departures & 0 \\
\hline late arrivals & 0 \\
\hline weather & 75 degrees, sunny \\
\hline members & $\begin{array}{l}\text { John Mandeville, Community Development Director } \\
\text { Phil Dunsmore, Associate Planner }\end{array}$ \\
\hline
\end{tabular}




\begin{tabular}{|c|c|c|}
\hline \multicolumn{3}{|c|}{ Meeting Characteristics } \\
\hline $\begin{array}{l}\text { purpose/focus of } \\
\text { meeting }\end{array}$ & \multicolumn{2}{|c|}{$\begin{array}{l}\text { Second workshop in a series of meetings about the SLO Housing } \\
\text { Element update process. }\end{array}$} \\
\hline $\begin{array}{l}\text { level of dialogue } \\
\text { staff to public } \\
\text { public to public }\end{array}$ & \multicolumn{2}{|c|}{$\begin{array}{l}\text { One-way communication from planner to public. Occasional questions } \\
\text { from audience disrupted monotonous flow. Speakers took turns to } \\
\text { break up presentation. No talking amongst public. }\end{array}$} \\
\hline $\begin{array}{l}\text { speaker duration } \\
\text { staff vs. public }\end{array}$ & $\begin{array}{l}\text { 50. Staff Presentation ( } 60 \mathrm{~min}) \\
\text { 51. Public Questions ( } 30 \mathrm{~min}) \\
\text { 52. Staff Response ( } 30 \mathrm{~min})\end{array}$ & $\begin{array}{l}\text { Staff: } 75 \% \\
\text { Public: } 25 \%\end{array}$ \\
\hline $\begin{array}{l}\text { visualization tools } \\
\text { maps, posters, } \\
\text { digital, } \\
\text { pamphlet }\end{array}$ & \multicolumn{2}{|l|}{ PPT, projector, screen. } \\
\hline structure & \multicolumn{2}{|c|}{$\begin{array}{l}\text { Main component of the event is the presentation. No engagement } \\
\text { exercises or games. Opinion survey handed out midway with housing } \\
\text { specific questions. Limited public involvement was in form of } \\
\text { questions about facts presented or City efforts on various topics such } \\
\text { as affordable housing. }\end{array}$} \\
\hline Setting & \multicolumn{2}{|c|}{$\begin{array}{l}\text { Community Center meeting hall. Round tables, everyone focused on } \\
\text { presenter standing by screen. Refreshments in back corner of room } \\
\text { (water, grapes, cookies, juice). Agendas in stack by presenter. } \\
\text { Diffused light. Multiple rooms adjoining and basketball court behind } \\
\text { closed doors. }\end{array}$} \\
\hline $\begin{array}{l}\text { stage in planning } \\
\text { process } \\
\left(1^{\text {st }}, 2^{\text {nd }}, 3^{\text {rd }}\right. \\
\text { meeting })\end{array}$ & \multicolumn{2}{|c|}{ Second meeting in series of three workshops. } \\
\hline $\begin{array}{l}\text { method of } \\
\text { interaction }\end{array}$ & \multicolumn{2}{|c|}{ Oratory/listener, opinion survey, question and answers at the end. } \\
\hline $\begin{array}{l}\text { public notification } \\
\text { method }\end{array}$ & \multicolumn{2}{|l|}{ Website, legal ads, local newspaper. } \\
\hline
\end{tabular}




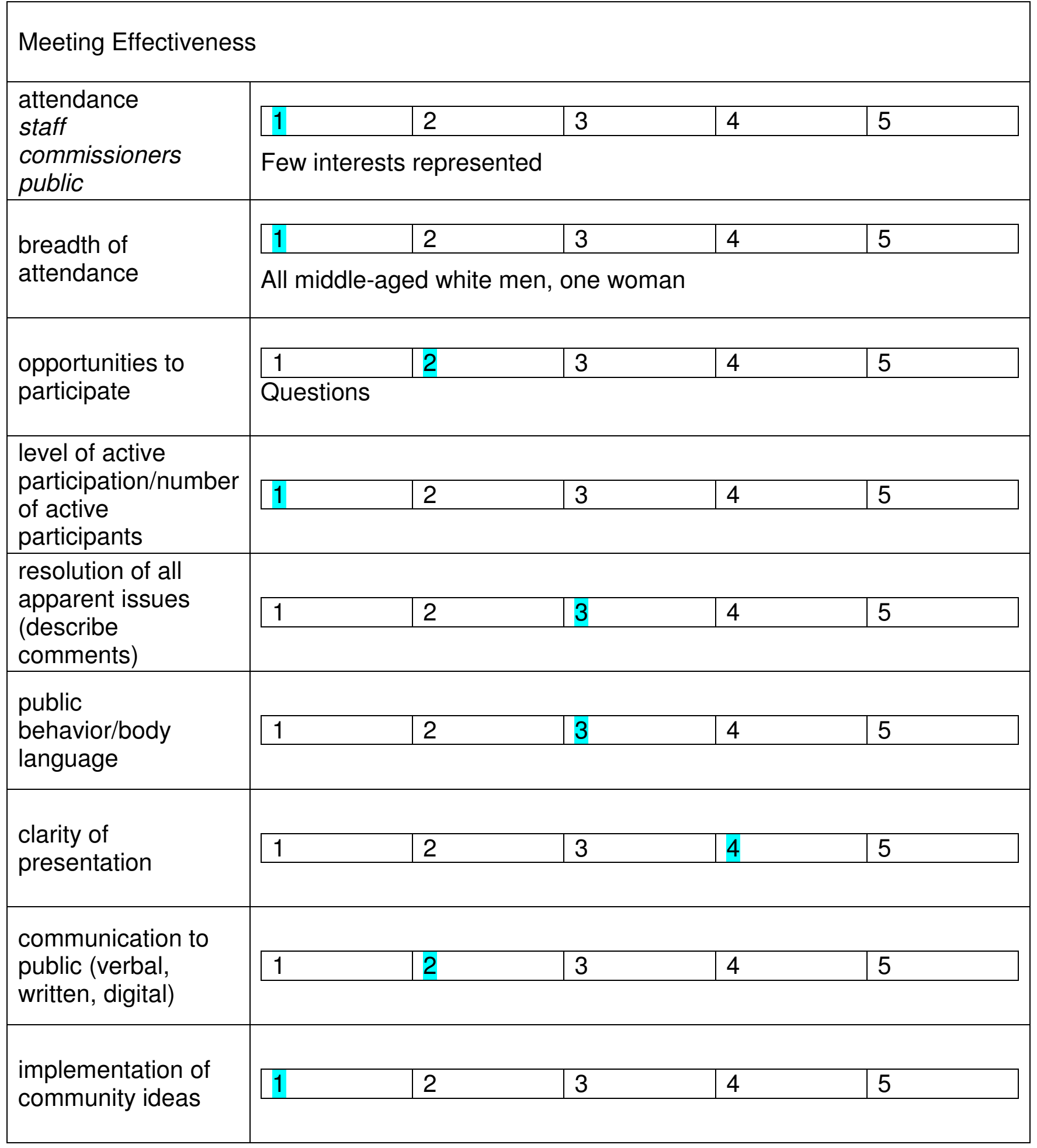


Further Observations

Sparsely attended meeting - everyone that did attend worked in a housing related field (People's Self Help, Housing Authority, County Planning). More excitement at workshop may have attracted more participants.

Time and day of workshop conflicted with major community event (Farmer's Market).

Overall presentation was informative and data heavy. 30 minutes of bullets and charts about demographics and housing statistics. A few questions broke up a multitude of slides that were hard to read at some times and filled with text. PPT was lacking graphics.

All participants were professionals in local planning as if the City had sent out a meeting request through an Outlook calendar. Staff presence was overbearing (two directors, senior planner, and associate planner) relative to public attendance. Presentation was about policies that had already been decided before the workshop. It appears public engagement came late in the Housing Element update process. Not genuine participation as Sanoff describes it.

Meeting was opportunity for public to evaluate policies, but there was too many to consider in one meeting. The average person would not be able to answer many of the survey questions without extensive review of the draft document beforehand.

There was no summation of the last workshop for new attendees. No discussion of input from previous workshop comments and the effect they had on development of the document. This prevents ability of community to take ownership of the plan.

The SLO workshop was a perfect example of a phrase commonly heard among the halls of government offices: "This is the way it has always been done". For a society that has evolved to become visual-based thinkers reliant on technology, opinion surveys and lectures don't cut it any longer.

Staff did not go for lack of trying. Overwhelming workloads among public sector employees influence the amount of time that can be attributed to organizing a good public workshop. Combined with a lack of funding it becomes clear that public participation events are overlooked. Is this a product of the cynicism from planners about people's interest in the Housing Element?

What are budget allocations for participation events?

What should local government planners do to make it more exciting than cookies and water? 


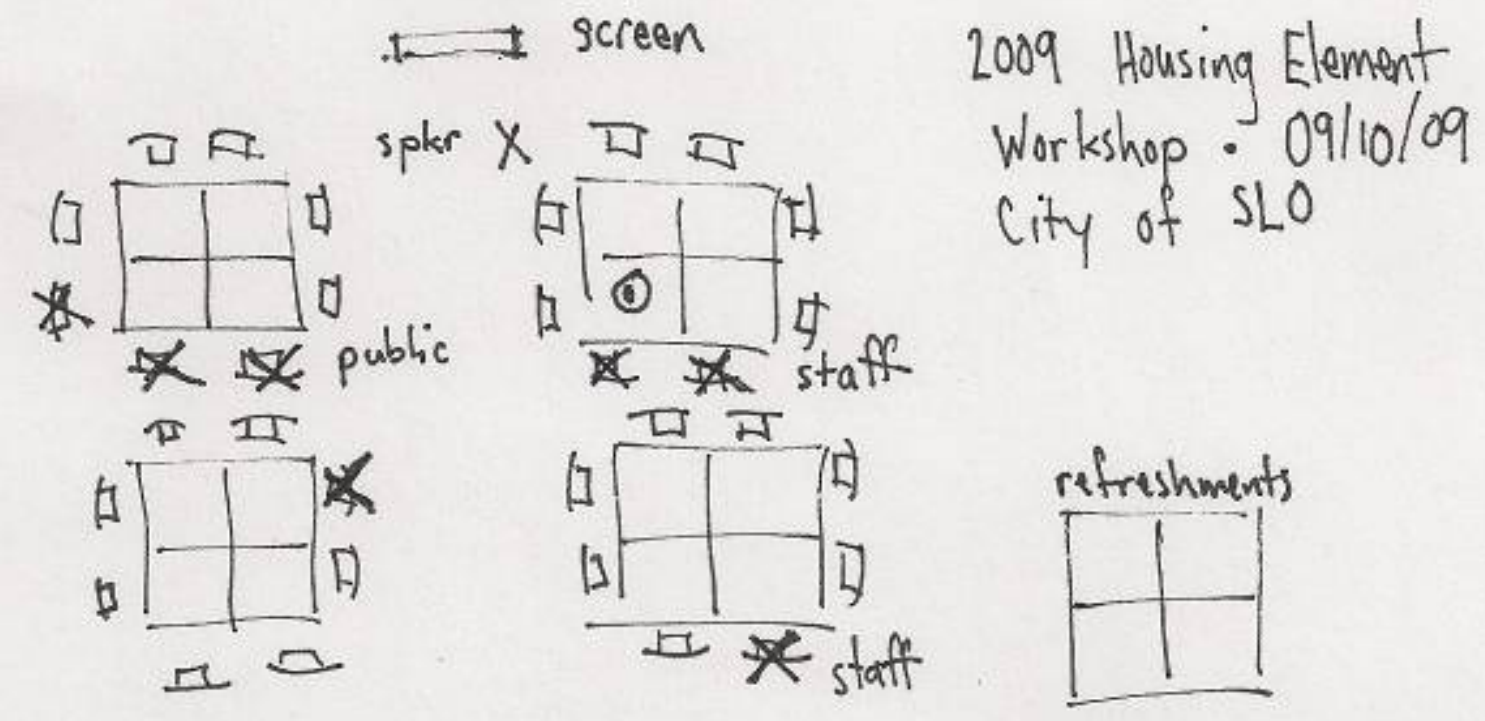




\section{Case Study \#W8}

\begin{tabular}{|c|c|}
\hline \multicolumn{2}{|l|}{ General data } \\
\hline event title & $\begin{array}{l}\text { SLO Climate Action Plan } \\
\text { Community Workshop }\end{array}$ \\
\hline methodology & Workshop \\
\hline location & $\begin{array}{l}\text { City/County Library Community Room } \\
\text { 995 Palm Street } \\
\text { San Luis Obispo, CA } 93401\end{array}$ \\
\hline date and time & $\begin{array}{l}11 / 19 / 2009 \\
6: 00 \mathrm{pm}\end{array}$ \\
\hline $\begin{array}{l}\text { mediator(s) } \\
\text { (number of } \\
\text { presenters) }\end{array}$ & $\begin{array}{l}\text { California Polytechnic State University } \\
\text { City and Regional Planning } \\
1 \text { student }\end{array}$ \\
\hline event duration & 2 hours \\
\hline attendance & 16 Cal Poly, 1 staff, 13 public \\
\hline early departures & 1 staff \\
\hline late arrivals & 1 public \\
\hline weather & 55 degrees, clear \\
\hline members & $\begin{array}{l}2 \text { Planning Commissioners } \\
\text { Deputy Director, Long Range Planning }\end{array}$ \\
\hline
\end{tabular}




\begin{tabular}{|c|c|c|}
\hline $\begin{array}{l}\text { purpose/focus of } \\
\text { meeting }\end{array}$ & \multicolumn{2}{|c|}{$\begin{array}{l}\text { Develop community-based action plan for addressing climate change. } \\
\text { Gather ideas for reducing emissions. Find out what residents want the } \\
\text { City government to do in terms of climate change. }\end{array}$} \\
\hline $\begin{array}{l}\text { level of dialogue } \\
\text { staff to public } \\
\text { public to public }\end{array}$ & \multicolumn{2}{|c|}{$\begin{array}{l}\text { Predominately public to consultant. Cal Poly presented a short } \\
\text { overview at beginning, but most dialogue was brainstorming in small } \\
\text { focus groups. Two groups total that answered prompts from } \\
\text { facilitators. }\end{array}$} \\
\hline $\begin{array}{l}\text { speaker duration } \\
\text { staff vs. public }\end{array}$ & $\begin{array}{l}\text { 53. Staff introduction }(5 \mathrm{~min}) \\
\text { 54. Consultant overview }(15 \mathrm{~min}) \\
\text { 55. Facilitator presentations }(25 \mathrm{~min}) \\
\text { 56. Feedback tables }(75 \mathrm{~min})\end{array}$ & $\begin{array}{l}\text { Consultant: } 33 \% \\
\text { Staff: } 4 \% \\
\text { Public: } 63 \%\end{array}$ \\
\hline $\begin{array}{l}\text { visualization tools } \\
\text { maps, posters, } \\
\text { digital }\end{array}$ & \multicolumn{2}{|c|}{$\begin{array}{l}\text { PPTs, } 4 \text { audiovisual screens, flipcharts, large-scale maps with } \\
\text { transparencies, markers, design games (placing symbolic stickers on } \\
\text { City base map), legends in front of seats with game instructions, } \\
\text { preference mapping (put dot next to most important feature of "green" } \\
\text { community), residence survey (place smiley face where you live), } \\
\text { posters. }\end{array}$} \\
\hline structure & \multicolumn{2}{|c|}{$\begin{array}{l}\text { Two groups of eight rotated between five activity stations. Each } \\
\text { station was organized around a category of emissions (buildings, } \\
\text { water, solid waste) or reduction strategy (green community, alternative } \\
\text { transit). Two facilitators who asked feedback questions manned } \\
\text { tables. Only one station had a design game. Time was split evenly } \\
\text { between stations (no breaks). Satisfaction survey at end. }\end{array}$} \\
\hline setting & \multicolumn{2}{|c|}{$\begin{array}{l}\text { Library community room with tables set up in five different stations. } \\
\text { Each station (except one) had a digital projector with PPT for issue } \\
\text { area. Public was dispersed during intro, and then asked to form two } \\
\text { groups to rotate counter clockwise around stations. When station was } \\
\text { empty, facilitators did nothing. } \\
\\
\text { Refreshment table with coffee, juice, crackers, cheese, cookies to one } \\
\text { side of room. Sign-in table with greeters at entrance had nametags for } \\
\text { participants. Residence survey immediately adjacent to sign-in table } \\
\text { with one person directing. }\end{array}$} \\
\hline $\begin{array}{l}\text { stage in planning } \\
\text { process }\end{array}$ & \multicolumn{2}{|l|}{ First meeting in a two meeting series. } \\
\hline $\begin{array}{l}\text { method of } \\
\text { interaction }\end{array}$ & \multicolumn{2}{|l|}{ Oratory/listener, small group, games. } \\
\hline $\begin{array}{l}\text { public notification } \\
\text { method }\end{array}$ & \multicolumn{2}{|c|}{$\begin{array}{l}\text { Website, press release, Facebook, posted flyers at local businesses, } \\
\text { postcards, school flyers, Farmer's Market booth, personal solicitation. }\end{array}$} \\
\hline
\end{tabular}




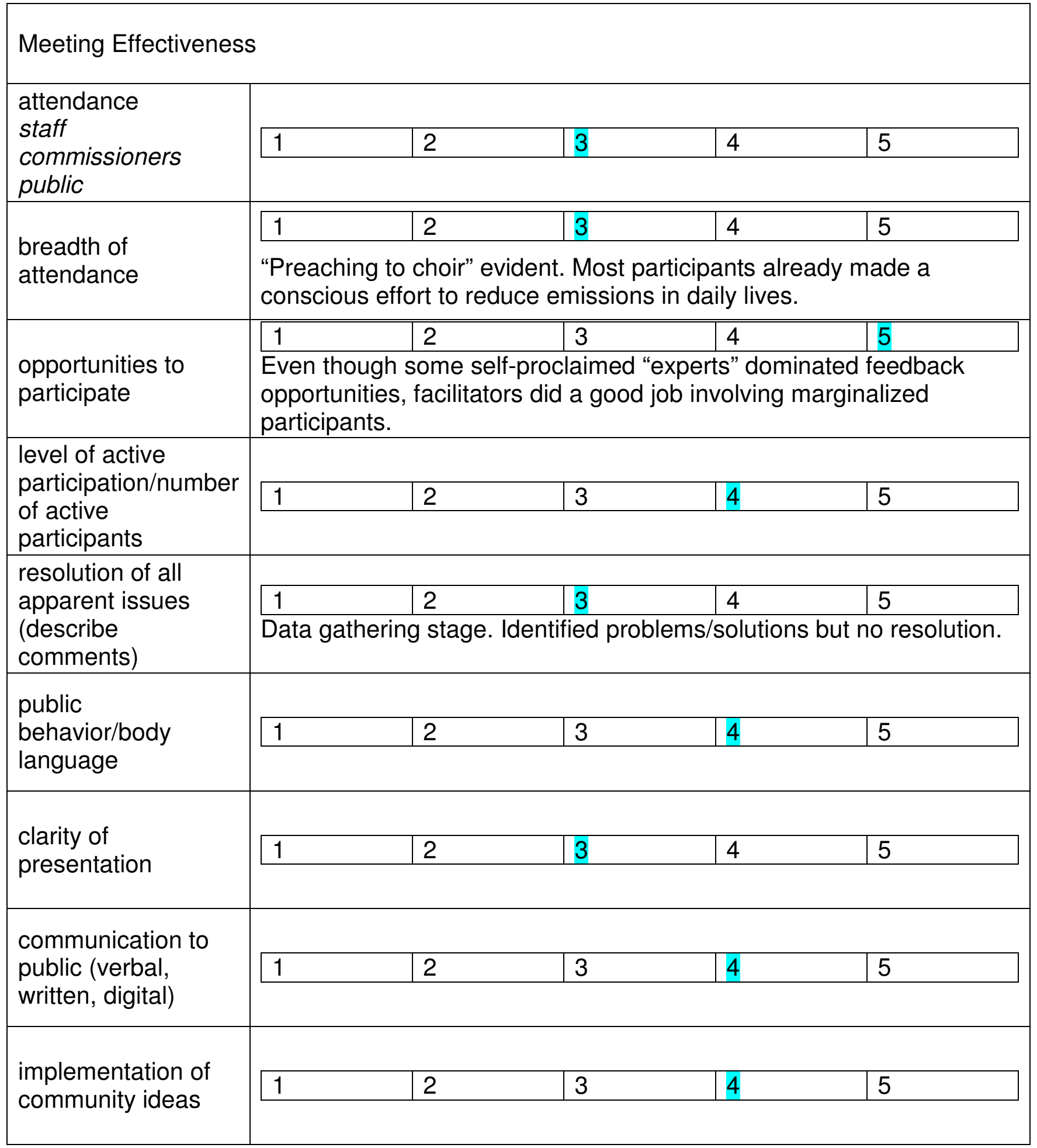


Further Observations

Meeting titled workshop yet distinction from other workshops observed: dialogue was question and answers between participants and facilitators with limited discussion amongst participants. Breakout tables were more like specialized focus groups. Facilitator asked questions, "what can we do", and participants answered while note-taker recorded on flip chart.

Many participants relied on personal stories to illustrate answers. One resident commented on how she liked a recent housing project downtown and is therefore in favor of infill development strategies. Another read a recent story about how solar was successful in a different part of California. Participants needed this step to comprehend issues in their own frame of experience.

Some personal accounts were disputed by others at the table. A participant was detailing the recycling process at the local Cold Canyon landfill, and another person refuted his claims. A slight argument occurred, but nothing overtly negative.

One dominator emerged from the group. This person talked louder than everyone else, never raised his hand, and was quick to respond when prompted. He used a lot of personal anecdotes of how he already practices environmentally friendly behavior in his own life. In the beginning it established his credibility, but as the group progressed through activity stations and his comments overpowered discussion, his comments shifted from credible to an air of self-righteousness.

The design game was confusing to many participants. Initial questions arose about what each symbol means and whether placing one sticker over another meant that priority was given to that particular interest (i.e. placing a local food sticker versus parks and recreation sticker on the base map). Once comprehension was evident among all participants, the design game was successful.

Interestingly, the facilitator used a base map for San Luis Obispo but told participants to design their dream city without bias to what already exists. The discussion was meant to be more general yet everyone got very specific about neighborhoods and corridors because it hit so close to home. The final product was a map with housing, commercial, services and amenities placed in locations very similar to what exists in San Luis Obispo today. Does this mean that residents are genuinely happy with the SLO's urban design? 
The presence of a Planning Commissioner in the small group diverted discussion from what should be done to what is the City doing. She was seen as an expert on local government activities and the public wanted to know more about what is happening now. Workshop would have been strengthened if more City employees were present to speak to public interests.

Remaining activity stations were focused on generating feedback about an issue. Small group presentations started with factoids and then displayed a discussion question. Face to face interaction between participants occurred when one person could identify with another's answer. Discussion snowballed from one person's response.

It was clear that most people were already "in the know" at this meeting. Residents without knowledge of environmental behaviors or residents that did not agree with recycling, water conservation, etc., were not represented. For generating ideas on how to reduce emissions, this was not a problem. It is good to rely on resident knowledge. However, the education component of public participation is somewhat lacking when everyone already knows more about the subjects being discussed than the average resident.

By the time the group reached Station Three, camaraderie was beginning to form. A few jokes are exchanged and more personal stories amongst group members surfaced.

Questions about factual sources arose at various tables, and some participants had difficult questions for facilitators. Overall, the group was attentive and satisfied with the process. Facilitators always started by thanking people for attending, and participants responded with, "It's nice to be involved in the process"...community ownership!

The workshop was appropriately timed because discussion started to break down at the last activity station. Two to three side conversations were observed and the facilitator was having a hard time reigning in the focus of the group. Perhaps people were losing interest in the workshop so it was good to end. However, when time expired one person stated, "Bummer, this is a good discussion!"

Children had their own related activities in a separate room: seed planting and coloring books. Judging from the amount of consultants and number of tables, it was apparent that Cal Poly was ready for a larger crowd. Despite extensive outreach efforts, attendance was relatively low. The meeting coincided with a major community activity, which may have deflated attendance numbers. Evidently, when compared to other meetings observed, attendance was pretty good! 


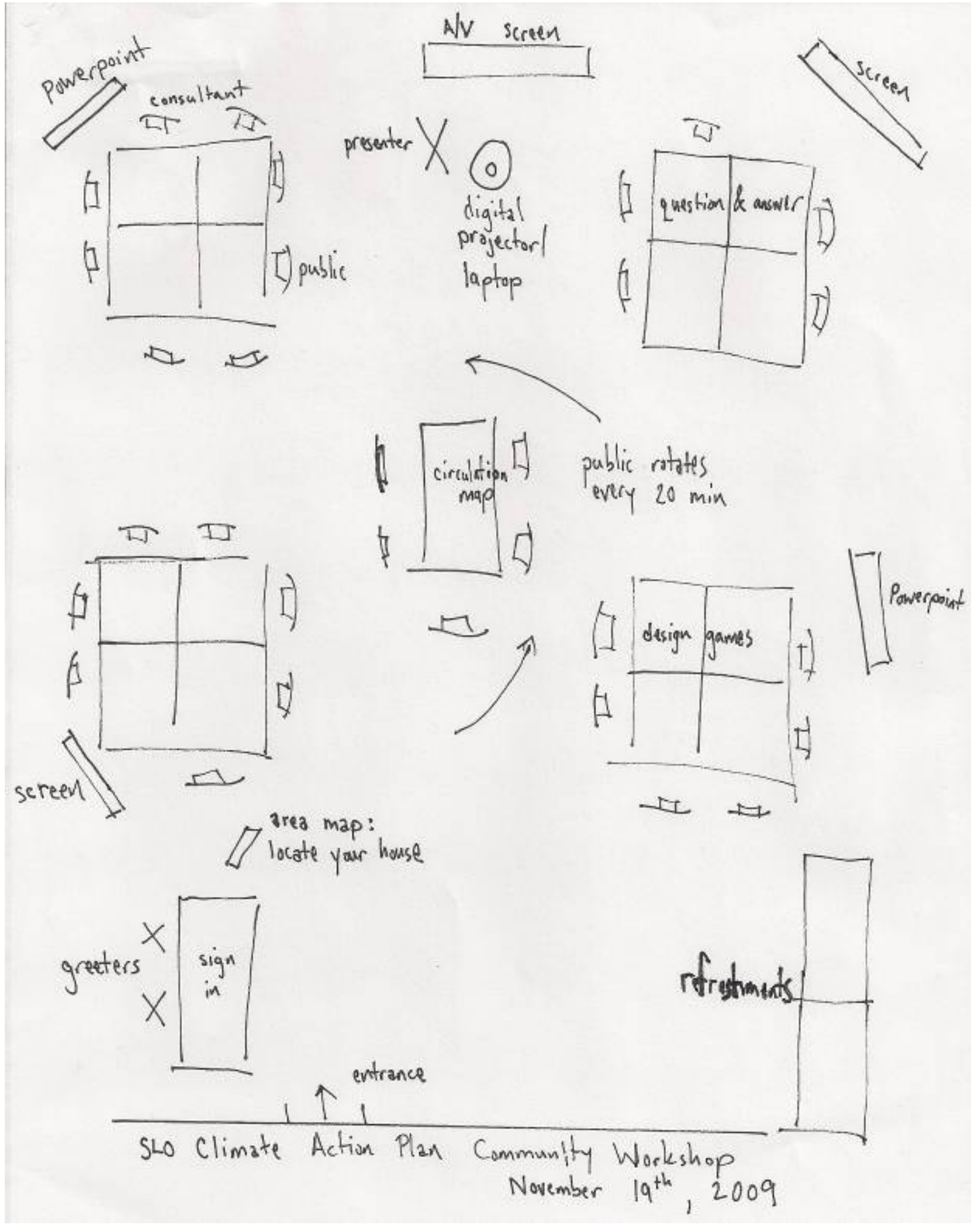

191 


\section{APPENDIX B: Interview Transcripts}

\begin{tabular}{|l|l|l|}
\hline Interviewee & City & Population \\
\hline Planner One & Santa Barbara & 90,000 \\
\hline Planner Two & Sacramento & 463,000 \\
\hline Planner Three & Los Angeles & $4,000,000$ \\
\hline Planner Four & San Diego & $1,300,000$ \\
\hline Planner Five & San Luis Obispo & 45,000 \\
\hline
\end{tabular}

Population Source: Census 2000 


\section{Planner One}

Organization: City of Santa Barbara

Department: Community Development

Duration: 26 years in public sector

Thank you for agreeing to this phone interview. I am conducting research on public participation for my master's thesis. As I mentioned in my email, I am evaluating the efficacy of public hearings versus public workshops in achieving genuine participation.

Based on my research and case studies, it appears that hearings are a form of pseudo participation - in that they inform, placate and consult the public. Workshops on the other hand are genuine participation because they elicit cooperation, partnership, and delegation of some control to citizens = empowerment.

Essentially, public hearings present information about what is being planned for the community and public workshops help facilitate decisions made by the community.

What are some of your thoughts on public participation?

It depends upon what the project is and who needs to weigh in on it. Hearings work well for private development projects, to determine things like whether or not the project is exempt from CEQA or if the developer is seeking an entitlement or permit. Workshops would not work on items the agency is considering for action. We do encourage applicants to talk as early as possible with their neighbors.

Does the City of SB have a pre-application process?

Yes. Projects are reviewed at a conceptual level at the Design board or a preapplication stage at staff level.

I noticed on your website YouPlanSB.org there is a workshop series for the City's General Plan update. What is the difference between hearings and workshops in terms of public participation?

Workshops are for policy updates, public-private sponsorships, or projects like a new complex or a public park. You need a reason to engage the public that makes sense. It depends on the nature of the project. Some projects are a "tell" with no room for varied opinion.

You have to be able to do something with information collected at workshops. Otherwise you are playing with the public's expectations. Know what to do with public feedback. 
What types of projects or planning activities are discussed at workshops? Scope? Citysponsored?

City-sponsored projects, General Plan, Area Plan, or projects with choices and options. We've done walking tours and held meetings in a workshop setting when the public had something to truly do and add. Sometimes there are hired consultants for design-oriented charrette exercises.

Sometimes it is a combination of workshops and hearings like our General Plan update. The Planning Commission may observe a workshop but then need to weigh in on the project at a hearing.

We got some substantial critique from our workshops on the General Plan update:

1. Trying to do too much;

2. Too many questions for small groups;

3. The makeup of groups was bad;

4. There were too many dominators.

The design of workshops and facilitation skills are important.

What stage in the planning process are workshops?

Early, usually first. The Commission then weighs in officially on workshop feedback at hearings. It is a careful balance of community discussion and official comment. The appointed body weighs in throughout the workshop series.

One of the reasons I decided to contact the City of $S B$ is because I am interested in the practicality of scale. Most of my case studies have been in cities in San Luis Obispo County with relatively smaller populations. What is the largest workshop you have organized? Was it successful?

At one of the "YouPlanSB" workshops there were well over 200 people including Spanish-speaking groups. It was a good turnout and we made efforts to reach Spanish speakers.

How do you manage a group that size?

We started with everyone assembled as one whole group in a large meeting room to explain small group exercises. One thing you need is good space to hear. At one point we had four groups in one small room and it proved difficult. Make sure you have enough space for breakout into small groups!

Is there a threshold when workshops get too big and lose efficiency?

It is hard to keep the interest of a larger group. You need skilled moderators to bring everyone back together for small group presentations. 
Is another format such as a public hearing preferred for items that generate significant public interest?

Again, it depends on the subject. We held two forums: one on public health and design, and the other an economic study panel. Each had a presentation, panel discussion, and we passed a mic for questions from audience. It was the act of disseminating information with no questions to ask the people. However, there were focus questions on everyone's mind like, "How do we promote affordable housing?"

Sounds like similar elements to a public hearing: panel versus commission, random public questions versus controlled public comment.

Yes, but it was more comfortable. 


\section{Planner Two}

Organization: City of Sacramento

Department: Community Development Department - Planning

Duration: 8.5 years

Please tell me a little more about your responsibilities in the department.

Supervisor of current planning, which is made up of planners reviewing private development applications and taking them through Planning Commission and City Council hearings.

What are some of your thoughts on public participation? (required, positive, negative, worthwhile)

In most cases public participation makes projects better. Notifying neighbors early is a good thing if it is organized.

In Sacramento, we have 50 to 60 established community associations or neighborhood groups. Some are long-standing and some form because of one project and stay together. Public participation is achieved through formal neighborhood association's early feedback and is helpful for projects.

What stage in the planning process do neighborhood groups participate?

Early in the process. An applicant may come in with a project during the preapplication phase that may generate controversy or affect a particular neighborhood. We suggest that the development team meet with the community prior to submittal. More money spent up front saves considerable time and money at the end.

When actual application submittals come in we route them for completeness first to all internal City departments, local government agencies, and State agencies. We also route them to all affected neighborhood associations. The neighborhood groups send letters or emails back to staff prior to public meetings. They know to engage developers and staff early versus waiting to comment at a public hearing like an average citizen.

Are the neighborhood associations all volunteers?

Most are concerned citizens participating on a voluntary basis. Some groups are business associations with dedicated funding such as a Private Business Improvement District (PBID).

Does the City of Sacrament hold public workshops often? 
Long-range planning holds workshops for public projects and that department would know more than me. Workshops for private development are sometimes held by the developer to engage the community or neighborhood. Developers will ask the community questions about land use, design or any other comments. Developers hold workshops rarely; it is more common that they appear at neighborhood group meetings to give a presentation as part of the agenda.

What types of projects or planning activities are discussed at workshops? Scope? Citysponsored?

City initiated projects like a transit plan centered around a light rail station or a new community plan. Workshop topics are farther reaching in scope.

One of the reasons I decided to contact the City of Sacramento is because I am interested in the practicality of scale. Most of my case studies have been in cities in San Luis Obispo County with relatively smaller populations. What is the largest workshop you have organized? Was it successful?

The Sacramento Rail Yards was an infill project that generated significant community interest. A private developer finally purchased it. There were half a dozen workshops some with attendance of 150 to 200 people. 3 joint commission meetings focused on design, preservation and planning at the Sheraton Hotel drew 70 to 80 community members. A lot of folks had been waiting for this project and there were some controversial impacts.

The workshop provided good opportunities for input. It was broken up into stations: transportation staffed with traffic engineers, land use and historic staffed with members of the Historic Preservation Committee. The 20-acre site contained transitional railroad buildings from the 1860s. There is a circulation and land use plan approved for the site. A site plan was approved in 1994 that never came to fruition. Staff and the community felt the project was not as good as it could be.

Is there a threshold when workshops get too big and lose efficiency?

It depends on how you structure your workshop. The Rail Yards was about 2-3 hours with a 5 minute intro from the Mayor, 5 minute vision from the developer, and direction from Staff on how the stations were setup. Then it was a free flow of conversations.

Asking questions of the public with no walking around is not going to be effective with more than 15 to 20 people. People start to get antsy, especially with PowerPoints and overheads. Putting information on a screen and asking questions is awful. Usually there is one person in the back yelling. Dispersing people and breaking it up by topics is beneficial to those who are interested in traffic impacts and not historic preservation. 
*In your opinion, what is the best way to involve large amount of residents? How do you gather representative input?

Get involved with a neighborhood group. Sacramento is a diverse city with different groups and different opinions. It is hard to get a lot of people involved unless there is passion. 90 percent of public hearing comments are negative. If you like the project, you are not going to get off your couch at $7 \mathrm{pm}$ and go down to a hearing. Topics have to be worthy of getting a lot of people.

Break up the meeting so that one corner is traffic, parks and open space, another corner is design, land uses. People in attendance can talk to a staff member and get the ability to comment station to station. Smaller scale meetings are effective, like a land use subcommittee, where 5 to 12 people can have a dialogue with one staff member.

How do we get better attendance at participation events?

Incentives. My wife and I both work full time and we have 2 kids so we are home at night. It would take a special permit for a drive-thru restaurant right next door to get me to a hearing after work. That's the problem, but maybe that's okay.

We notice everyone within 500 feet of projects. One accomplishment I have made is making language on public notices understandable using plain language instead of plannerese. It is financially challenging to send a large quantity of notices especially when 50 percent won't respond. Neighborhood groups can blast email as well.

It seems you need a controversial project for people to show up. Some measure of quality of life need be threatened. The Mercy Hospital expansion had so much passion on both sides. It is located in an affluent neighborhood and we built a new heart center. It was a billion dollar expansion on the Hospital that filled the Council chambers with a couple hundred people. Video streamed to another room with overflow seating. With lots of added conditions the Council approved it. 80 people at 2 minutes a person spoke. Some organized by topic. Again, a lot of passion. People came out to speak about the positive as a reaction to the negative. 


\section{Planner Three}

Organization: City of Los Angeles

Department: Department of City Planning

What are some of your thoughts on public participation? (required, positive, negative, worthwhile)

We are a gigantic city. We have a hundred of those things all year long.

Does the City of Los Angeles hold public workshops often?

We've tried everything, and in different languages too: workshops, hearings, formal, informal, focus groups, living room chats. Everything is always in Spanish and English. We try to incorporate the community, which is challenging in poorer neighborhoods. There is considerable diversity of people for every topic. We don't plan and tell them what we are going to do.

What is the difference between the two in terms of public participation?

Hearings are required by law. They are always a part of a project. It takes at least 3 public hearings at decision making bodies before it gets to the full City Council. Hearings are formulated - you get comments about whether people hate a project, love it or want to change it. Hearings are usually at the end of a 3 to 5 year long planning process, with other public participation events first.

What types of projects or planning activities are discussed at workshops? Scope? Citysponsored?

Everything. Projects proposed to be built in a neighborhood. Projects that effect everyone in the whole community. Specific plans, small area plans, code amendments, City projects - the whole gamut.

Tell me more about Certified Neighborhood Councils (CNC) and Area Planning Commissions (APC).

Recent legislation established CNCs and APCs throughout Los Angeles communities. CNCs involve all aspects of community, not just homeowners. They look at planning, economic development, and bylaws. It is required that the CNC is representative of the community and made up of renters and homeowners.

APCs devolve decision-making downward. They review big areas of the City, and Commissioners have to live or work in those areas. The APCs look at smaller things. Citywide projects go to the Planning Commission. 
One of the reasons I decided to contact the City of Los Angeles is because I am interested in the practicality of scale. Most of my case studies have been in cities in San Luis Obispo County with relatively smaller populations. What is the largest workshop you have organized? Was it successful?

$500+$ people. What is success? Goals may be different like seeking consensus or getting representative input. One guy had to be removed by security guards recently.

We are multi-lingual for everything, with bilingual staff, and graphics in two languages. For long range projects there are multiple rooms with stations for transportation, urban design, and land use. Participants and staff interact at stations in an open house setting. People are more willing to talk in this setting instead of called up to a microphone. You still must try to engage them though.

*In your opinion, what is the best way to involve large amount of residents? How do you gather representative input?

Questionnaires are good. Website interactive forums for our bike plan received over 1,000 comments. To involve younger people you need to be web savvy. When you are doing a community plan participants are over 70 .

How do we get better attendance at participation events?

Special consultants are hired to do that. Get in touch with nonprofits that have a big presence in the community. There good neighborhood standing helps organize poorer areas. Mailings don't work for fear of immigration issues. In rich areas mailings are okay. Actually go to churches in African American communities.

We used nontraditional methods in South L.A. in a poorer community for a planned transit stop. The consultant, staff and 18 residents took a trip from South L.A. to Portland. Some had never flown in a plane. We rode on every rail, met with officials, neighborhoods, nonprofits and stayed in a nice hotel. All participants were involved in neighborhood groups in L.A. and we made a video for Planning Commission. They got to see things firsthand and were more articulate in their own community. The community took ownership. It took years to convince the bureaucracy because of costs. Some thought you could just show them a picture. They have to experience it. Participants noticed plants, benches, and other things you wouldn't think about in a picture. 


\section{Planner Four}

Organization: City of San Diego

Department: City Planning \& Community Interest

Title: Community Planning Program Manager

Duration: 8.5 years

Please tell me a little more about your responsibilities in the department. Public/private?

Implementation side of long-range planning, interaction with Community Planning Groups, grant writing.

What are some of your thoughts on public participation? (required, positive, negative, worthwhile)

It is a vital part of the process, yet often isn't done as good as it could be. The project proponent interacts with the community, and it takes longer to satisfy everyone. Public participation is about education and trust earned over time. Trust is not possible the first time. You need to spend time with people over a long enough period.

Does the City of San Diego hold public workshops often?

Depending on the scope of the project. Some projects go a long time without a hearing. Participation has to and should occur. It does help answer a lot of questions and vet issues.

What is the difference between the two in terms of public participation?

Hearings result in a legal decision and must adhere to a legally defined process while workshops are focused on providing information and educating commissioners and the public.

What types of projects or planning activities are discussed at workshops? Scope? Citysponsored?

City-sponsored projects. There are 42 community plans in the City. Every update has public workshops with the Planning Commission. No decision is expected, just discussion of progress, issues, resolutions, and an opportunity to pose questions early in the process. The community at-large is being informed and the Planning Commission making decisions another day. 
Describe the structure of these workshops. Did the Commission sit on a typical raised dais and deliberate?

Yes. Staff presented and reports followed like an actual hearing. There was opportunity for the Planning Commission and public to comment.

Tell me more about Community Planning Groups (CPG) and the Community Planners Committee (CPC).

CPGs are advisory bodies to the City on land use issues and specific plan amendments. They are based on geographic areas corresponding to the 42 community plans. CPGs review projects according to policy language in their Community plan. They are an elected body that reviews policy, operating procedures, administrative guidelines monthly, and makes recommendation to City Council. CPCs are the chairs of all the CPGs. Staff tries to resolve any issues from split votes ahead of time before City Council review.

One of the reasons I decided to contact the City of Los Angeles is because I am interested in the practicality of scale. Most of my case studies have been in cities in San Luis Obispo County with relatively smaller populations. What is the largest workshop you have organized? Was it successful?

One successful workshop was the Barrio Logan Community Plan update. It was a 3 hour public forum held in a warehouse. Each plan element was broken into stations and staff gathered information from people going to each station. It was progressive with no end result other than a compilation of comments.

Food is important. When citizens are going to extra meetings that are not hearings especially with children - you have to give them extras to help focus their attention on planning details. Holding meetings outdoors is problematic because of ADA access requirements. We just hold everything at the Planning Commission to ensure Brown Act compliance.

Is there a threshold when workshops get too big and lose efficiency?

No. Size is proportionate to scope. Participation may need to be citywide so it usually held at the Planning Commission. Ineffectual meetings happen when homework is not done. Staff running the meeting needs to involve all departments early.

In your opinion, what is the best way to involve large amount of residents? How do you gather representative input?

Languages are a big deal. English and Spanish translators and headsets for translation are a part of the budget. They help facilitate participation and tell the community we value their input and want to hear their voice. 
How do we get better attendance at participation events?

Public noticing is a 300 foot requirement in San Diego. Finding a voice in the community that people already trust. Find a church, stakeholder, or other contact to rally the community. Start a stakeholders committee with a key person from each group who attends regular meetings. Keep it moving along to avoid loss if interest. Taking too long could mean your stakeholders change and it starts all over again. 


\section{Planner Five}

Organization: City of San Luis Obispo

Department: Community Development

Duration: 6 years

What are some of your thoughts on public participation? (required, positive, negative, worthwhile)

I agree with what you said. It is more difficult to get genuine participation at hearings, when people only have three minutes nervousness sets in. It is difficult given the setting.

A public hearing is information presented and a recommendation on the books. So much work is already done and confirmed. Hearings are required. You have to do it.

There is a lot to be said for workshops. People get to be a part of the process, are consulted early and feel like they are involved regardless of outcomes.

Why the formalities in public hearings?

It is legally required. It has always been done by Robert's Rules of Order. There might be some flexibility, but there are legal requirements for big decisions by the Council and City Attorney.

Public hearings are business meetings where civic engagement is not happening. The Council is conducting business in a public forum. There is a motion, first, second, vote, and a decision.

What types of projects or planning activities are discussed at workshops? Scope? Citysponsored?

City-sponsored long range projects: South Broad Street Corridor Plan, Orcutt Area Specific Plan, Housing Element. Some developers do outreach at neighborhood meetings but rarely organize workshops.

What is the largest workshop you have been involved in? Was it successful?

Dinosaur Caves Park in Pismo Beach. The City of Pismo and consultants held the workshop in the community building at the park. There were $100+$ people in attendance. It was a high profile project with safety concerns due to sinkholes near the coast. Input from the public was actually reflected in the plan regarding tot lots and other design items. Neighbors attended to protect their views of the ocean. The 
name of the park was a tribute to a big plastic attention grabbing dinosaur that used to be located nearby.

How do you manage a workshop that size?

Breakout groups sitting around a table with one person speaking at a time and a facilitator providing information. You need a staff member to set the stage in the beginning with a presentation but then break up in groups. It makes people feel like a part of it. Some people are nervous, but giving them a sense of being included can help foster good ideas that are followed through the process.

You need good rovers and facilitators with experience. Planners would benefit from rolling training in these skills into college curriculum.

Is there a threshold when workshops get too big and lose efficiency?

5 tables at 6 to 8 per table is a good maximum. 10 tables is pushing it and the workshop is much longer because of additional small group presentations.

A task force of key representatives is helpful when groups are large or an issue is controversial. Participants then report back to their interest groups.

In your opinion, what is the best way to involve large amount of residents? How do you gather representative input?

Workshop method is good. Online and social media is a growing arena for networking. Although elderly citizens don't want anything to do with 3D models or Tweets!

How do we get better attendance at participation events?

It is difficult because most people already worked a full day. It is always the same old folks and gadflys. Varying times, new technology, social media, online forums have real promise.

Public Relations, make it exciting, incentives, goodies, treats, slogan, newspaper ads, "spin it" as to why it is in everyone's interest. Some topics will generate interest on their own. The most important thing is to be open to input and carry it forward. Don't ask for comments, say "thanks", and never do anything with it. 